

UNIVERSIDADE DE BRASÍLIA

Faculdade de Ciências da Saúde

Programa de Pós-Graduação em Bioética

Uma Análise da Cirurgia Bariátrica à luz da Declaração Universal Sobre Bioética e Direitos Humanos: Não-Discriminação e NãoEstigmatização da Pessoa com Obesidade Mórbida

SHEILA PEREIRA SOARES

Brasília, DF 


\author{
UNIVERSIDADE DE BRASÍLIA \\ Faculdade de Ciências da Saúde \\ Programa de Pós-Graduação em Bioética
}

\title{
Uma Análise da Cirurgia Bariátrica à luz da Declaração Universal Sobre Bioética e Direitos Humanos: Não-Discriminação e Não- Estigmatização da Pessoa com Obesidade Mórbida
}

Tese apresentada ao Programa de Pós-
Graduação em Bioética da Universidade de
Brasília, como requisito para a obtenção do
título de Doutor em Bioética. Área de
concentração: Bioética e Saúde Pública.

SHEILA PEREIRA SOARES

Orientador: Prof. Dr. Natan Monsores de Sá

Brasília, DF 
Soares, SP.

Uma Análise da Cirurgia Bariátrica à luz da Declaração Universal Sobre Bioética e Direitos Humanos: Não-Discriminação e Não-Estigmatização da Pessoa com Obesidade Mórbida.

Sheila Pereira Soares - Brasília, 2017.

$234 p$.

Orientador: Professor Dr. Natan Monsores de Sá

Faculdade de Ciências da Saúde. Programa de Pós-Graduação em Bioética. Universidade de Brasília - UnB. 2017.

1. Introdução; 2. Estudo da Arte e Fundamentação Teórica; 3. Objetivos; 4. Percurso Metodológico; 5. Resultados e Discussão; 6. Considerações Finais; 7. Referências; Anexos e Apêndices. 


\section{SHEILA PEREIRA SOARES}

\section{Uma Análise da Cirurgia Bariátrica à luz da Declaração Universal Sobre Bioética e Direitos Humanos: Não- Discriminação e Não-Estigmatização da Pessoa com Obesidade Mórbida}

Tese apresentada ao Programa de Pós-Graduação em Bioética da Universidade de Brasília, como requisito para a obtenção do grau de Doutor em 03 de Março de 2017.

\section{BANCA EXAMINADORA}

\begin{tabular}{|c|}
\hline $\begin{array}{l}\text { Prof. Dr. Natan Monsores de Sá } \\
\text { Universidade de Brasília (FS/UnB) } \\
\text { Presidente }\end{array}$ \\
\hline $\begin{array}{c}\text { Prof. Dr. Maria da Glória Lima } \\
\text { Universidade de Brasília (FS/UnB) } \\
\text { Membro }\end{array}$ \\
\hline $\begin{array}{c}\text { Prof. Dr. Wanderson Flor do Nascimento } \\
\text { Universidade de Brasília (FFil/UnB) } \\
\text { Membro }\end{array}$ \\
\hline $\begin{array}{c}\text { Prof. Dr. Fabiano Maluf } \\
\text { Universidade de Brasília (SESDF) } \\
\text { Membro }\end{array}$ \\
\hline $\begin{array}{c}\text { Prof. Dr. Saulo Ferreira Feitosa } \\
\text { Universidade de Brasília (UFPE) } \\
\text { Membro }\end{array}$ \\
\hline $\begin{array}{c}\text { Prof. Dr. Pedro Sadi Monteiro } \\
\text { Universidade de Brasília (FS/UnB) } \\
\text { Suplente }\end{array}$ \\
\hline
\end{tabular}


Aos meus filhos Guilherme e Enzo que são minha razão de viver...

A minha mãe Lúcia que, sempre permaneceu ao meu lado em todos os momentos...

Especialmente àqueles que passaram por minha vida e no meio do percurso se acovardaram, olharam para trás e viraram estátuas de sal...também àqueles que as escondidas menosprezaram minha aparência e inteligência, pensando ser "eles/elas" de uma classe ou raça superior...a estes digo: estou de pé e vou caminhar até o pódio porque a vida me ensinou que a deselegância não se restringe apenas a roupas, sapatos e cabelos, estes podem ser comprados, mas a deselegância de caráter não tem conserto. Como diz Caetano Veloso (Música Dom de lludir) "Cada um sabe a dor e a delícia de ser o que é."

Enfim, a todas as pessoas intimamente ligadas à minha vida e que realmente se importam e torcem pelo meu sucesso. 
Para fazer as pazes com a balança, é fundamental estar em paz consigo mesmo.

Mary Scabora

Kelly Kathryn C. de Oliveira

Independente de quão maravilhosa possa ser a máquina do corpo, é a presença da alma que faz com que ela funcione.

Ken O'Donnell 


\section{AGRADECIMENTOS}

Obrigada Deus, meu amigo, companheiro, refúgio, fortaleza e consolador. Posso lhe agradecer porque vivo em um país dito laico e que me permite cultua-lo sem discriminação. Este trabalho não é resultado apenas de um esforço individual. Ele nasce de significativas contribuições que recolhi durante minha trajetória profissional, acadêmica e como cidadã, ao lidar com pessoas e instituições que foram fundamentais a essa construção.

Consciente de que é impossível listar todos que de uma forma ou de outra me acrescentaram conhecimentos e experiências essenciais à forma de ver o mundo e nele atuar - particularmente em relação à área da saúde e da assistência de enfermagem - não vou expressar meus agradecimentos de forma nominal para não frustrar, por lapso de memória, amigos(as) com quem convivo e que a cada dia me faz perceber que sou produtiva e importante.

Preciso registrar a contribuição dos professores que fazem parte do Programa de Pós-Graduação em Bioética, em especial ao Coordenador Professor Dr. Volnei Garrafa, minha eterna admiração e respeito. Ao meu Orientador Professor Dr. Natan Monsores de Sá que literalmente me adotou e provou que é sim um ser iluminado (meu anjo), possuidor de raras características: competente, inteligente, educado, disciplinado, paciente e discreto. Permito-me utilizar neste espaço uma frase dita por meu primogênito “mãe...você tem que agradecer porque o professor Natan é o cara", tenho consciência que a expressão "o cara" é extremamente informal, contudo teve a intenção de destacar alguém que em minha opinião é EXCLUSIVO. Agradeço aos professores participantes da Banca Examinadora por se dispor e compartilhar este momento tão importante e esperado.

$\mathrm{E}$, por último, mas não menos importante, aos participantes deste estudo, por possibilitar a coleta de dados. E as Gerentes de Enfermagem Enf ${ }^{a}$ Edilamar Melo de Lucena e Enfa ${ }^{-}$Edna da Silva Flor pela compreensão e sensibilidade ao permitir uma escala de trabalho diferenciada para conclusão do doutorado. Muito obrigada. 


\section{LISTA DE SIGLAS}

AMB - Associação Médica Brasileira

AMM - Associação Médica Mundial

ANS - Agência Nacional de Saúde Suplementar

ANVISA - Agência Nacional de Vigilância Sanitária

AVE - Acidente Vascular Encefálico

CBM - Cirurgia Bariátrica e Metabólica

CEP - Comitês de Ética em Pesquisa

CF - Constituição Federal do Brasil

CFM - Conselho Federal de Medicina

CIB - Comitê Internacional de Bioética

CIOMS - Conselho de Organizações Internacionais de Ciências Médicas

CNS - Conselho Nacional de Saúde

COESAS - Comissão das Especialidades Associadas

CONANDA - Conselho Nacional de Direitos da Criança e do Adolescente

CONEP - Conselho Nacional de Ética em Pesquisa

CONSEA - Conselho Nacional de Segurança Alimentar e Nutricional

CRMSP - Conselho Regional de Medicina de São Paulo

DCNT - Doenças Crônicas Não Transmissíveis

DNA - Ácido Desoxirribonucleico

DUBDH - Declaração Universal sobre Bioética e Direitos Humanos da UNESCO

EU - União Européia

EUA - Estados Unidos da América

FAEC - Fundo de Ações Estratégicas e Compensação

FAO - Organização das Nações Unidas para a Alimentação e a Agricultura 
FDA - Food and Drug Administration

FEPECS - Fundação de Ensino e Pesquisa em Ciências da Saúde

GM - Gabinete do Ministro

GVB - Gastroplastia Vertical com Bandagem

HRT - Hospital Regional de Taguatinga

IBGE - Instituto Brasileiro de Geografia e Estatística

IHME - Instituto de Métrica e Avaliação para a Saúde

IMC - Índice de Massa Corporal

MS - Ministério da Saúde

OCDE - Cooperação e Desenvolvimento Econômico

OMS - Organização Mundial de Saúde

ONGs - Organizações Não-Governamentais (ONGs)

ONU - Organização das Nações Unidas

PIB - Produto Interno Bruto

PNE - Portador de Necessidades Especiais

RN - Resolução Normativa

SPFW - São Paulo Fashion Week

SBCBM - Sociedade Brasileira de Cirurgia Bariátrica e Metabólica

SENAI-CETIQT - Centro de Tecnologia da Indústria Química e Têxtil do Serviço Nacional de Aprendizagem Industrial

SESDF -

SIDA - Síndrome da Imunodeficiência Adquirida

SM - Síndrome Metabólica

STJ - Superior Tribunal de Justiça

SUS - Sistema único de Saúde

TCLE - Termo de Consentimento Livre e Esclarecido

UNESCO - Organização das Nações Unidas para a educação, a ciência e a cultura 
UNOSIDA - Programa das Nações Unidas sobre HIV / AIDS.

VIH - Vírus da Imunodeficiência Humana

WE - Encefalopatia de Wernicke 


\section{LISTA DE TABELAS}

Tabela 1. Classificação da obesidade segundo a OMS.

Tabela 2: Classificação da obesidade segundo a Sociedade 43 Americana de Cirurgia Bariátrica e pela Federação Internacional da Obesidade.

Tabela 3. Número de cirurgias bariátricas entre os anos de 2003 a 58 2014 no Brasil no Sistema Público e Privado.

Tabela 4. Dados sócio-demográficos, idade, gênero, religião, 135 estado civil, escolaridade, renda familiar e categoria profissional.

Tabela 5. Percepção da quantidade de alimentos ingeridos antes 138 do procedimento.

Tabela 6. Doenças relacionadas à obesidade, que você 144 apresentava antes do tratamento cirúrgico.

Tabela 7. Classificação do seu Peso Corporal antes do 145 tratamento cirúrgico.

Tabela 8. Auto avaliação - Histórico Físico e Social antes do 147 tratamento cirúrgico. 


\section{LISTA DE QUADROS}

Quadro 1. Prevalência da Obesidade mórbida no Brasil por distribuição regional da população entre os anos de 1974 a 2003. 


\section{RESUMO}

O presente estudo objetivou analisar, sob uma visão bioética, o procedimento Cirurgia Bariátrica e Metabólica (CBM) como uma técnica capaz de interferir nas dimensões corporais e sociais, tendo como referência os princípios bioéticos do "Benefício e Dano" e "NãoDiscriminação e Não-Estigmatização" listados na Declaração Universal sobre Bioética e Direitos Humanos da Unesco nos artigos $4^{\circ}$ e 11 respectivamente, assim bem como os relatos de gastroplastizados. A Cirurgia bariátrica tem como principal objetivo a melhora do quadro clínico da pessoa com obesidade mórbida por meio da redução de comorbidades em consequência da perda ponderal. Contudo, este procedimento tem ultrapassado os limites na medicina e biologia, interferindo de forma benéfica na redução da discriminação e estigmatização da pessoa com obesidade mórbida, resgatando a dignidade outrora perdida e favorecendo a inclusão social pela aceitação individual e coletiva da nova imagem corporal. Trata-se de uma pesquisa com abordagem quanti-qualitativa. A população corresponde 0 universo formado por 25 servidores gastroplastizados do Hospital Regional de Taguatinga (HRT). A pesquisa foi direcionada aos indivíduos maiores de 18 anos, gastroplastizados a igual ou superior a um ano. Os participantes da pesquisa pertenciam a diversas categorias profissionais, portanto: médicos, enfermeiros, técnicos em enfermagem, farmacêuticos, nutricionistas e técnicos de laboratório. O instrumento escolhido para coleta de dados desta pesquisa foi o questionário. O questionário de autopreenchimento foi elaborado contendo 34 perguntas em formato Aberta, Fechada e Semi-aberta. $O$ instrumento apresentava quatro dimensões partindo de um contexto geral até chegar a um contexto mais específico: (1) Perfil sócio-demográfico; (2) Histórico físico, de saúde-doença, social e familiar antes da realização da CBM incluindo a relação do indivíduo com seu corpo e a imagem corporal, da relação com a sociedade e sobre os temas discriminação e estigmatização (3) As mudanças pessoais e sociais após o procedimento; e (4) Abordagem ética no processo do tratamento e sobre satisfação ou insatisfação em relação ao procedimento. A análise dos dados qualitativos foi feito por meio de leitura crítica, identificando os pontos que mereciam maior atenção no sentido de confirmar os objetivos do estudo. Os dados quantitativos obtidos a partir da tabulação dos questionários foram expostos e analisados conforme a disposição dos mesmos de acordo com o questionário. A técnica escolhida foi a Análise do Discurso que segundo Pêcheux tem como objetivo a análise de comunicações na tentativa de tornar os fatos mais concretos possíveis. $O$ que permite enquadrar melhor os objetivos propostos, pois explora a relação entre o discurso e a realidade. Os resultados mostram que o sofrimento moral vivenciado pelo corpo obeso devido à discriminação relaciona-se diretamente ao grau de obesidade, quanto maior o Índice de Massa Corporal (IMC) mais problemas psicológicos estão presentes. Desta forma, além de carregar o peso de seu corpo, o corpo obeso leva consigo o peso da culpa e da responsabilidade por sua obesidade. Por meio das falas dos participantes foi possível compreender como a imagem corporal e a autoestima estão relacionadas com os discursos das mídias e sociedade que pulverizam a padronização corporal e a modelagem da identidade. Diante dos dados considera-se necessário que os diálogos bioéticos sejam introduzidos nos ambientes educacionais, profissionais e sociais tendo como objetivo minimizar os agravos físicos, mentais e sociais sofrido pela pessoa obesa e a sociedade em geral.

Palavras-Chaves: Corporeidade, Obesidade Mórbida, Cirurgia Bariátrica e Metabólica, Bioética, Declaração Universal Sobre Bioética e Direitos Humanos, Benefício, Dano, NãoDiscriminação, Não-Estigmatização, Educação. 


\begin{abstract}
The objective of this study was to analyze the Bariatric and Metabolic Surgery procedure (MBS) as a technique capable of interfering with the body and social dimensions, based on a bioethical view, based on the bioethical principles of "Benefit and Damage" and "Non-Discrimination and Non-Stigmatization "listed in the Universal Declaration on Bioethics and Human Rights of Unesco in articles 4 and 11 respectively, as well as reports of gastroplasty. Bariatric Surgery has as main objective the improvement of the clinical picture of the person with morbid obesity through the reduction of comorbidities as a consequence of weight loss. However, this procedure has exceeded the limits in medicine and biology, interfering in a beneficial way in reducing the discrimination and stigmatization of the person with morbid obesity, rescuing the formerly lost dignity and favoring social inclusion through the individual and collective acceptance of the new body image. It is a research with quantitative-qualitative approach. The population corresponds to the universe formed by 25 gastroplanted servers of the Regional Hospital of Taguatinga (HRT). The research was directed to individuals over 18 years of age, who were gastroplanted for at least one year. The participants of the research belonged to several professional categories, therefore: doctors, nurses, nursing technicians, pharmacists, nutritionists and laboratory technicians. The instrument chosen to collect data from this research was the questionnaire. The self-completion questionnaire was prepared containing 34 questions in open, closed and semi-open format. The instrument presented four dimensions from a general context to a more specific context: (1) Socio-demographic profile; (2) Physical, healthdisease, social and family history prior to MBS, including the relationship of the individual to his or her body and body image, the relationship with society and the issues of discrimination and stigmatization (3) Personal changes After the procedure; And (4) Ethical approach in the treatment process and satisfaction or dissatisfaction with the procedure. The analysis of the qualitative data was done by means of critical reading, identifying the points that deserved more attention in order to confirm the objectives of the study. The quantitative data obtained from the tabulation of the questionnaires were exposed and analyzed according to their disposition according to the questionnaire. The technique chosen was the Speech Analysis that according to Pêcheux aims to analyze communications in an attempt to make the facts more concrete. This allows us to better frame the proposed objectives, since it explores the relationship between discourse and reality. The results show that the moral suffering experienced by the obese body due to discrimination is directly related to the degree of obesity, the higher the Body Mass Index (BMI) plus psychological problems are present. In this way, in addition to carrying the weight of your body, the obese body carries with it the burden of guilt and responsibility for its obesity. Through the speeches of the participants it was possible to understand how the body image and the self-esteem are related to the discourses of the media and society that pulverize the corporal standardization and the modeling of the identity. Given the data, it is considered necessary that bioethical dialogues be introduced in the educational, professional and social environments in order to minimize the physical, mental and social damages suffered by the obese person and society in general.
\end{abstract}

Key Words: Corporeity, Morbid Obesity, Bariatric and Metabolic Surgery, Bioethics, Universal Declaration on Bioethics and Human Rights, Benefit, Damage, Non-Discrimination, NonStigmatization, Education. 


\section{SUMÁRIO}

1. INTRODUÇÃO 16

2. ESTADO DA ARTE E FUNDAMENTAÇÃO TEÓRICA 25

2.1 A CONSTRUÇÃO CORPORAL E SUA REPRESENTAÇÃO 25 SOCIAL

2.2 PANORAMA DA EPIDEMIOLOGIA DA OBESIDADE EM 41 ALGUNS PAÍSES DO MUNDO

2.2.1 Obesidade no Brasil 46

2.3 CIRURGIA BARIÁTRICA E METABÓLICA (CBM) 52

2.3.1 Legislação brasileira sobre CBM $\quad 59$

$\begin{array}{ll}\text { 2.3.2 Aspectos positivos CBM } & 68\end{array}$

$\begin{array}{ll}\text { 2.3.3 Aspectos negativos da CBM } & \mathbf{7 0}\end{array}$

2.4 BIOÉTICA E SAÚDE PÚBLICA 75

2.4.1 O princípio do "Benefício e Dano" $\quad 81$

2.4.2 O princípio da "Não-Discriminação e Não-Estigmatização" 90

2.5 OBESIDADE NO CAMPO DA BIOÉTICA 102

2.6 CIRURGIA BARIÁTRICA E METABÓLICA NO CAMPO DA 115 BIOÉTICA

3. OBJETIVOS 122

3.1 Geral 122

3.2 Específicos 122

4. PERCURSO METODOLÓGICO 123 
$\begin{array}{ll}\text { 4.1 Tipo de pesquisa } & 123\end{array}$

4.2 Fonte Primária e Fontes Secundárias de Dados 124

4.3 Local de Realização da Pesquisa 125

4.4 Universo, Perfil dos Participantes e Abordagem 125

4.5 Instrumento para Coleta de Dados e Aplicação 127

$\begin{array}{ll}\text { 4.6 Aspectos Éticos da Pesquisa } & 128\end{array}$

4.7 Ressarcimento ou Indenizações por Danos 129

4.8 Ordenamento e Técnica de Análise dos Dados 130

$\begin{array}{ll}\text { 5. RESULTADOS E DISCUSSÕES } & 133\end{array}$

6. CONSIDERAÇÕES FINAIS 166

$\begin{array}{lr}\text { 7. REFERÊNCIAS } & 177\end{array}$

ANEXO I - Resolução CFM nº 1.942/2010 207

ANEXO II - Resolução CFM n² 2.131/2015 213

ANEXO III - Protocolo para Cirurgia Bariátrica e Metabólica $\quad 217$

APÊNDICE A - Termo de Consentimento Livre e Esclarecido 224

APÊNDICE B - Questionário 226 


\section{INTRODUÇÃO}

Inicialmente a ideia central para a pesquisa de doutoramento seria abordar as questões bioéticas que circundam o procedimento denominado de Cirurgia Bariátrica e Metabólica (CBM) por integrar as novas tecnologias em saúde e ser considerada a última alternativa no combate à obesidade mórbida até o momento.

Adotando assim, os conceitos de CBM como sendo um conjunto de técnicas ou procedimentos médicos, invasivo, que tem como objetivo inicial a redução do estômago, isto é, a redução da capacidade de armazenamento e da capacidade de absorção dos alimentos, cujo objetivo final é a perda de peso e a redução ou cura das doenças correlacionadas; o de Tecnologia em Saúde compreendida como todas as intervenções que podem ser utilizadas para promover a saúde, prevenir, diagnosticar, tratar, reabilitar ou cuidar de doenças em longo prazo, incluindo medicamentos, dispositivos, procedimentos e sistemas de organização e suporte dentro dos quais se fornece o atendimento 1,2 .

A análise bioética seria alicerçada especificamente no artigo $4^{0} \mathrm{da}$ Declaração Universal sobre Bioética e Direitos Humanos (DUBDH) da Unesco ${ }^{3}$ Organização das Nações Unidas para a educação, a ciência e a cultura que aborda os princípios do Benefício e Dano. Porém, abordar somente os benefícios e danos que circundam a CBM enfatizando a anatomia e fisiologia não traria inovação ao tema já que inúmeros trabalhos e pesquisas foram e estão sendo realizados com foco mais fisiológicos.

Então, como a obesidade passou a ser um assunto de interesse universal a partir do momento em que ultrapassou a barreira do individual passando a invadir e interferir no espaço coletivo seria interessante analisar também de que forma ocorre está invasão na vida do outro, como a sociedade se manifesta diante da pessoa obesa e quais os conflitos existentes nesta relação. Para uma aproximação mais íntima das questões bioéticas com 0 tema CBM houve a necessidade de uma reflexão antropológica e sociológica 
da relação homem, corpo e sociedade, sendo necessário envolver o estudo da corporeidade em relação ao corpo obeso no meio social, especificamente o corpo com obesidade mórbida.

A escolha e inserção do artigo 11 da DUBDH foi necessário como forma de expor os conflitos em torno da pessoa obesa referente à discriminação e estigmatização e quais as possibilidades de amenizar ou resolver a problemática já que o referido artigo traz simultaneamente os princípios da Não-Discriminação e Não-Estigmatização como caminhos a serem traçados para conscientizar, educar, prevenir preconceitos e promover a aceitação da pluralidade corporal e intermediar conflitos. Tornando assim, os temas CBM, obesidade e bioética como interligados e indissociáveis.

Neste sentido, a presente pesquisa passa então a analisar as questões com uma visão bioética mais focada sobre a tecnologia em saúde, isto é, a CBM como procedimento que envolve consequências físicas, psíquicas e sociais, que são atravessadas pelo fenômeno global denominado obesidade. Destacando os artigos $4^{\circ}$ e 11 da DUBDH $^{3}$ como referências para direcionar a revisão bibliográfica e a pesquisa de campo, conforme citação a seguir:

\footnotetext{
Artigo 4 - Benefício e Dano - Os benefícios diretos e indiretos a pacientes, sujeitos de pesquisa e outros indivíduos afetados devem ser maximizados e qualquer dano possível a tais indivíduos deve ser minimizado, quando se trate da aplicação e do avanço do conhecimento científico, das práticas médicas e tecnologias associada.

Artigo 11 - Não-Discriminação e Não-Estigmatização - Nenhum indivíduo ou grupo deve ser discriminado ou estigmatizado por qualquer razão, o que constitui violação à dignidade humana, aos direitos humanos e liberdades fundamentais.
}

Já faz algum tempo que a obesidade não significa simplesmente uma afronta estética, mas um problema de saúde pública que coloca alguns sistemas do país em risco econômico, envolvendo mudanças diretas e indiretas em todos os sistemas de produção de bens e serviços, que inclui, desde a indústria alimentícia, a farmacêutica, a têxtil, a medicina, as biotecnologias, os sistemas de saúde e judiciário, e afetando principalmente o sagrado ambiente familiar em seus hábitos e costumes. 
Hoje, o ato de se alimentar possui diferentes significados: saciedade, beleza, saúde, felicidade, gratificação, prazer, riqueza, compulsão, compensação, pobreza, doença e tristeza. A fome se posicionou em segundo plano como necessidade fisiológica sendo superada pelo prazer em ingerir alimentos saborosos e enriquecidos de gorduras e açucares com intuito de agradar o paladar e não necessariamente nutrir o organismo, em paralelo a isto, o excesso de peso e a obesidade disputam o primeiro lugar como um dos maiores problemas de saúde pública da atualidade.

Esta inversão trouxe a substituição de uma alimentação saudável que trazia benefícios por uma má alimentação em qualidade e quantidade que veio acompanhada por problemas complexos e danosos para o organismo e para a sociedade. As doenças agregadas à obesidade e as mudanças na forma corporal dos indivíduos também alterou o cotidiano.

A obesidade mórbida modifica a forma corporal de maneira tal que a sociedade passa a rejeitar o indivíduo e excluí-lo do ambiente social. Então, para melhor compreensão sobre aceitação e não aceitação da imagem corporal seja pelo próprio indivíduo ou por terceiros, foi adotado neste estudo o conceito de Imagem Corporal como sendo a figuração do corpo formado na mente, ou seja, como este corpo se apresenta a si mesmo e ao outro ${ }^{2,4}$.

Analisar as metamorfoses do corpo humano é abordar também os problemas psicológicos, biológicos e sociais que desencadeiam estas alterações sejam elas naturais ou artificiais. Isto significa que o corpo individual está em constante autoconstrução para se manter integrado aos outros corpos que compõe a sociedade. A relação entre os corpos permite a troca de emoções e percepções contribuindo na formação da identidade individual e coletiva $^{5}$.

As palavras ditas pelos outros podem ser incorporadas ao corpo individual, sendo assim personificadas de tal forma que o outro passa a ter poder sobre o corpo do indivíduo, tornando-se o corpo um componente além do orgânico, mas também psicossocial, cultural, religioso e também de simulação como afirma Rosário ${ }^{5}$ que os corpos no mundo pós-moderno tem adotado a 
construção do simulacro, uma aparência artificial que não condiz com a realidade, com a intenção de se adaptar a cada vontade e a pluralidade de sentidos.

Para esta análise de construção, desconstrução e reconstrução corporal a partir da ideia de que o corpo sofre interferência direta dos costumes, comportamentos e cultura da sociedade do qual faz parte. Também é necessário aceitar que este corpo adoece, Daí importa destacar a doença, neste caso a obesidade e as possibilidades de tratamentos, incluindo as modificações corporais para reconstrução de uma nova imagem com o objetivo de tentar equilibrar os conflitos internos e externos.

A obesidade mórbida é considerada uma doença crônica e multifatorial que tem origem: metabólica, genética e ambiental. Resume-se em um acúmulo excessivo de gordura como fonte de reserva em determinadas partes do corpo, ocasionando um desequilíbrio anatômico e funcional, além de riscos e complicações decorrentes das doenças associadas ao excesso de peso, como doenças cardiovasculares, articulares e respiratórias, entre outras alterações patológicas ${ }^{2}$.

O manejo clínico da obesidade é sempre necessário. A mortalidade dos obesos mórbidos predomina na faixa etária de 25 aos 35 anos, aumentando em doze vezes a possibilidade destes indivíduos morrerem precocemente comparativamente às pessoas com peso ideal. Poucos dados são encontrados na literatura sobre obesos mórbidos que alcançaram os 70 anos de idade, sendo que nestes casos a maioria morre em consequência de patologias associadas ${ }^{6}$.

Hoje, no Brasil existem mais de 52,5\% (aproximadamente 70 milhões) de pessoas com excesso de peso, enquanto 17,9\% (aproximadamente 15 milhões) são consideradas obesas. Segundo a Associação Médica Brasileira (AMB) é necessário o enfrentamento do problema de forma a criar uma estrutura mais adequada de combate à obesidade ${ }^{7,8}$. O Brasil está entre os países com maior índice de obesidade mórbida, alcançando o segundo lugar, sendo os Estados Unidos da América (EUA) o primeiro da lista. O número de 
obesos mórbidos no Brasil em 2014 era de 6,8 milhões, representando 3,6\% da população, o que é considerado uma grande demanda para o número de cirurgias realizadas no país que neste mesmo ano foram 88 mil cirurgias de redução de estômago, um número ainda considerado pequeno diante da grande população obesa ${ }^{8}$.

A CBM é considerada atualmente o tratamento mais eficaz para a obesidade mórbida, também denominada de obesidade grau III, classificada como doença pela Organização Mundial da Saúde (OMS) desde 1984, é o grau máximo da obesidade, um estado grave em que algumas morbidades já estão instaladas como hipertensão arterial, diabetes, arteriosclerose, doenças ósseas, vasculares e pulmonares, também já há maiores riscos de aparecimentos de alguns cânceres, por exemplo, nas mulheres, do endométrio (5,4 vezes), da vesícula biliar (3,6 vezes), do colo uterino (2,4 vezes), do ovário (1,6 vezes) e de mama (1,5 vezes). Nos homens, as taxas de cânceres também se elevam, o do cólon (1,7 vezes) e da próstata (1,3 vezes) ${ }^{7}$.

Existem várias técnicas da CBM, estas são aplicadas de acordo com a necessidade, perfil corporal, grau de obesidade e apresentação clínica de cada indivíduo. Os mecanismos utilizados para a redução do peso ponderal se fundamentam na restrição alimentar por meio da diminuição do conteúdo ingerido por meio da redução do reservatório gástrico, e do encurtamento e desvio intestinal, o que resulta em uma absorção intestinal reduzida ou desviada. A CBM deve ser adotada somente quando os métodos tradicionais, como por exemplo, dietas, aumento da atividade física e tratamento medicamentoso, se mostrarem pouco efetivos ${ }^{6}$.

Existem normas e protocolos adotados em todo o mundo para que pacientes sejam submetidos à cirurgia bariátrica ${ }^{2}$. No Brasil, o Conselho Federal de Medicina (CFM) regula o procedimento por meio da Resolução CFM no 1.942 de Fevereiro de $2010^{\circ}$. Há procedimentos restritivos não definitivos e cirurgias mistas com uso de duas técnicas, sendo estas intervenções definitivas em sua maioria ${ }^{2,8}$. Muitos destes procedimentos são considerados intervenções radicais e irreversíveis. Por isto não devem ser utilizadas como uma solução para fins estéticos, pois provocam mudanças anatômicas (internas e externas), 
fisiológicas e alterações psicológicas severas que a princípio são consideradas benéficas, mas que ao longo do processo do tratamento podem trazer complicações relacionadas com a não aceitação das transformações corporais, comportamentais e dos hábitos alimentares ${ }^{6,10}$.

Por ser um procedimento definitivo vale ressaltar a importância da avaliação dos riscos e benefícios que este procedimento traz para a saúde. Atribuir à CBM, de forma genérica, como sendo a única "salvação" ou solução para pessoas com obesidade e portadoras de doenças associadas, parece ser uma ideia questionável do ponto de vista da segurança, da satisfação do paciente e principalmente da associação do processo com o risco de morte porque toda cirurgia tem seu grau de risco; no caso dos procedimentos cirúrgicos da obesidade esta taxa é ainda mais elevada por se tratar de uma cirurgia de grande porte.

Deve-se ter cuidado em todo o processo de avaliação do candidato e aplicação do procedimento, pois a procura pela CBM tem aumentado em todo o mundo, e o preconceito pessoal, familiar e social enfrentado pelo obeso tem sido identificado como principais motivos na busca pelo procedimento. As dificuldades encontradas em relação às adaptações dos serviços públicos e privados também são problemas na vida do obeso, o que gera desrespeito quando se pensa em tratamento justo e equânime. Por exemplo, os investimentos públicos nos programas e tratamentos direcionados à pessoa obesa ainda são relativamente pequenos no Brasil, o que causa frustração e indignação de quem sofre com o problema.

Tudo isto está associado ao preconceito contra as pessoas com obesidade que persiste ao longo do tempo porque existe uma aceitação ainda que velada e passiva por parte da sociedade. A obesidade mórbida interfere na qualidade de vida do ser humano, afeta o fisiopatológico e está ligado ao desequilíbrio da saúde mental. Pesquisadores afirmam que todo obeso tem um perfil compulsivo, o que gera a ingesta exacerbada de alimentos, tendo como consequências outras morbidades que estão diretamente relacionadas ao excesso de gordura corporal ${ }^{11}$. 
Relacionar a Bioética à CBM é tema recente, por ser a bioética uma disciplina relativamente "nova", isto é, com pouco tempo de existência. Ainda existem poucos estudos interligando os campos (obesidade, cirurgia bariátrica e bioética). Assim sendo, este estudo permitiu ultrapassar as fronteiras da literatura e, buscar melhor compreensão sobre algumas questões referentes às mudanças e repercussões reais - físicas e psíquicas. Houve a necessidade de obter informações diretamente de pessoas que passaram pelo procedimento CBM com intuito de conhecer os motivos e necessidades que as levaram a buscar a CBM como último recurso.

A estrutura deste trabalho está constituída de Introdução, nove capítulos e considerações finais. Logo na introdução, é feita uma apresentação estrutural do trabalho defendendo a importância da inserção e discussão dos temas cirurgia bariátrica e obesidade no campo da bioética, partindo da ideia de uma bioética plural que respeita as diversidades, mas também respeita as particularidades de cada indivíduo. Esclarecendo que a obesidade se tornou um assunto universal por ser considerada atualmente um problema de saúde pública comprometendo de forma negativa à saúde individual e coletiva, exigindo mudanças sociais, políticas, econômicas, culturais, e principalmente em todo o processo de produção e venda de produtos alimentício, farmacêuticos, têxtil e biotecnocientífico.

O primeiro capítulo concentra-se na construção corporal e sua representação social, revelando que o corpo reflete os anseios sociais em diferentes momentos da história, muitas vezes reprimindo os seus desejos em prol do ideal coletivo. E que o corpo não perfeito, especificamente o corpo obeso que passa a ser considerado um corpo doente e rejeitado por não ser sinônimo do padrão global de beleza. Aborda também os conflitos entre 0 indivíduo e o coletivo e a relação entre os corpos na sociedade moderna.

O segundo capítulo mostra o panorama da epidemiologia da obesidade em alguns países do mundo, incluindo o Brasil, além de trazer o conceito de obesidade, suas origens, os fatores determinantes intrínsecos e extrínsecos, bem como as estratégias que o governo brasileiro tem usado para tentar reduzir e combater o avanço do fenômeno obesidade. 
O terceiro capítulo traz o histórico da cirurgia bariátrica e metabólica, desde as primeiras técnicas, sua evolução, aprimoramento, até chegar às técnicas mais utilizadas no mundo e no Brasil, assim como as legislações e órgãos brasileiros responsáveis por regular, fiscalizar e autorizar a realização das mesmas. Destaca-se também os aspectos positivos e negativos do procedimento na vida do gastroplastizado e da sociedade.

O quarto capítulo aborda a bioética no contexto da saúde pública, mostrando sua importância no processo de compreensão da dinâmica social e sua inserção e participação na elaboração de políticas públicas, inclusive no campo da saúde. E como a DUBDH pode ser importante como ferramenta para assimilação e reflexão dos direitos do cidadão, priorizando o diálogo entre educadores e profissionais de saúde como multiplicadores do conhecimento, de forma a fortalecer o controle social e o Sistema Único de Saúde (SUS).

Neste contexto, o profissional de saúde se torna peça chave no resgate do respeito à autonomia dos pacientes, especificamente os obesos, fomentando e contribuindo para a otimização de um modelo de atenção voltado para a valorização do ser humano e melhoria da qualidade de vida do cidadão. Também são apresentados os conceitos e reflexões sobre os princípios do "Benefício e Dano" e da "Não-Discriminação e Não-Estigmatização".

O quinto capítulo tem a pretensão de inserir a obesidade mórbida nas discussões bioéticas e dar continuidade a todo seu processo histórico, evoluído de maneira a valorizar a liberdade de escolha, a reflexão no campo do saber, da educação, a análise e discussão da ética e da moral. A intenção é explicitar as ideias de alguns estudiosos da ética e de bioeticistas em relação ao tema, não tendo a intenção de analisar de forma a julgar se estes estão certos ou errados, se estão sendo justos ou injustos. Mostrar que a obesidade pode ser analisada de diferentes ângulos.

O objetivo é reforçar o exercício da liberdade de expressão e ideias, mostrar que os diálogos bioéticos são necessários para a busca de soluções para problemas reais, buscando sempre o equilíbrio, a alteridade, tolerância, respeito à pluralidade em todos os aspectos seja político, cultural, econômico 
ou social. Cada cidadão tem o direito de expor suas ideias, merecendo ser ouvido e colocado em discussão seus aspectos normativos e éticos.

Daí o porquê da bioética estar inclusa no campo da filosofia moral, ela reforça a convivência pacífica entre os povos, trabalhando o exercício da justiça, a autonomia, a beneficência e a não maleficência, sendo que para a prática destes princípios se faz necessário o respeito no convívio entre os díspares, pois o indivíduo faz parte da sociedade, seja ele magro, obeso, feio, bonito, branco ou negro, e a sociedade é formada por estes indivíduos, isto quer dizer que o problema de um é problema de todos.

O sexto capítulo destaca a visão de diferentes autores sobre o processo de cirurgia bariátrica e metabólica e as implicações éticas e bioéticas envolvidas. Tem o objetivo de informar a visão e o posicionamento destes diante das questões obesidade e CBM e sobre o que está sendo realizado na prática, importante despertar o senso crítico da sociedade, permitindo assim o direito de escolha após o acesso a informação e dar fala aos "mudos sociais" por meio daqueles que defendem ou são contra o procedimento, isto nada mais é que a personificação da bioética por meio dos discursos bioéticos.

O sétimo capítulo apresenta o objetivo geral da pesquisa e os objetivos específicos. Já o oitavo capítulo descreve a trajetória metodológica adotada, os métodos e técnicas aplicados para realização do projeto, destacando a delimitação da amostra, as características dos participantes, o desenvolvimento do trabalho de campo e como se procedeu ao ordenamento dos dados para análise. Finalizando, o nono capítulo focaliza os resultados e a discussão pertinente, proporcionando reflexão e análise sobre a existência de conexão entre os objetivos propostos.

O conjunto da pesquisa procura revelar um tema aparentemente comum, mas que tem a ambição de se aprofundar em uma dimensão social específica. A bioética é quase sempre colocada como um conjunto de ferramentas capaz de analisar o conhecimento técnico, mas também deve observar, ouvir e valorizar as vivências do outro, partindo do individual para compor um conjunto, isto é o coletivo. 


\section{ESTADO DE ARTE E FUNDAMENTAÇÃO TEÓRICA}

\subsection{A CONSTRUÇÃO CORPORAL E SUA REPRESENTAÇÃO SOCIAL}

$\mathrm{Na}$ busca de um maior entendimento sobre a corporeidade, buscou-se como respaldo teórico a visão antropológica e sociológica da construção corporal e da simbologia do corpo na sociedade moderna indo além da barreira das ciências da saúde, porém não deixando de apresentar o corpo como um organismo que possui estruturas e funções específicas como um sistema biológico.

O termo corporeidade aqui entendido como a maneira pela qual 0 cérebro reconhece e utiliza o corpo como instrumento relacional com o mundo, foi escolhido por abordar o corpo de maneira mais aprofundada e abrangente, conforme o pensamento de Le Breton ${ }^{12}$ que o corpo pode ser moldado pelo contexto social e cultural ao qual o sujeito está inserido. Optar por estes referenciais, significa ampliar a percepção, compreensão e noção de um corpo não somente físico e psicológico, mas como um corpo participante do ambiente social, permitindo assim um estudo da corporeidade.

O corpo vem sendo estudado a partir de diferentes práticas como sendo uma entidade orgânica social e cultural. A filosofia, a antropologia, a sociologia e as artes conseguem enxergar o corpo além das barreiras biológicas, a medicina ainda encontra dificuldade para ultrapassar a barreira dos aspectos anatômicos e fisiológicos e deixar de estudar o corpo apenas como um objeto de intervenção, mas sim como bio-político-social.

Em uma reflexão de corpo no contexto da modernidade de um mundo capitalista os corpos são vistos como algo maleável e capaz de produzir e consumir, como afirma Le Breton ${ }^{12}$ (p. 79):

Toda a ordem política vai de encontro à ordem corporal. A análise leva a critica do sistema político identificado com o capitalismo que impõe a dominação moral e material sobre os usos sociais do corpo e favorece a alienação. 
Para observar e estudar o corpo também é necessário envolver questões éticas e bioéticas que estão enraizadas na existência e nas relações do ser humano com o mundo, isto implica reconhecer que o corpo é uma unidade participativa e significativa da sociedade. Vários temas podem ser estudados envolvendo a bioética e a corporeidade como aborto, sexualidade, transplantes, clonagem, obesidade, cirurgias plásticas, entre outros. O corpo pode ser compreendido como um vetor importante para a construção da identidade do indivíduo e para a construção de uma sociedade baseada nas relações sociais ${ }^{12}$.

A corporeidade busca estudar os significados e simbologias do corpo na cultura de uma sociedade, analisando as práticas corporais, a partir de métodos e princípios que partem da ideia inicial de comunicação, controle, disciplina e adaptação destes e por meio destes corpos. Importante destacar que o homem não deve ser estudado em relação à cultura, mas ser estudado como sujeito da cultura porque a história de cada civilização está intimamente ligada à história do corpo humano, cada particularidade do corpo origina a construção cultural e histórica de homens e mulheres ao longo do tempo ${ }^{13}$.

O aspecto corporal tornou-se alvo de grande importância na sociedade de consumo, principalmente com o desenvolvimento de técnicas na área da medicina e estética que oferecem tratamentos capazes de prolongar a juventude, a beleza e a saúde destes corpos. Cada vez mais os recursos financeiros individuais estão sendo direcionados à construção, reconstrução e manutenção da imagem corporal devido à insatisfação dos indivíduos e da sociedade com seus próprios corpos. A imagem corporal acompanha o indivíduo desde o seu nascimento até o último suspiro, sofrendo adaptações e transformações globais de acordo com o momento vivido ${ }^{14}$.

A insatisfação com o corpo pode ter origens diversas, uma delas é quando há falhas na interação social do indivíduo, pois dependendo da forma como este corpo se apresenta pode ser aceito ou rejeitado. Tudo depende do enquadramento deste corpo no padrão estético determinado pela mídia e sociedade. Uma boa estética favorece uma vida social agradável por meio do reconhecimento, admiração e uma aparente liberdade deste corpo. Muitas 
vezes os indivíduos não sabem que os corpos são controlados e direcionados ao processo de imitação pelo poder de padronização e concordância estética social que retira de forma subliminar a autonomia da pessoa ${ }^{14}$.

Nunca na história da humanidade o corpo foi tão cultuado como nos dias atuais, a busca pela perfeição, em manter uma aparência agradável tendo como principal motivação a busca da felicidade, aceitação, sensualidade e sexualidade. O corpo imperfeito, fora dos padrões sociais, traz inibição, vergonha, tristeza e exclusão. Na antiguidade os corpos sempre foram admirados, a exibição do corpo representava saúde, beleza e poder ${ }^{14}$.

Mas nem sempre o homem pensou no corpo como algo bom, um breve estudo sobre a construção e percepção corporal na antiguidade será necessário apenas para compreender as diferentes concepções de visão de corpo entre alguns filósofos e estudiosos. A intenção é apenas fazer um resgate histórico para melhor compreensão das manifestações corpóreas atuais.

As concepções mais antigas sobre o corpo vão além da fronteira material. Platão ${ }^{15,16}$ considerava o corpo como o local de habitação da alma, afirmando a existência de um dualismo psicofísico, que a alma é a parte imortal e o corpo a parte mortal, denominando o corpo como o cárcere da alma, pois a alma ficava aprisionada temporariamente no corpo e assim impedida de contemplar a perfeição, somente com a morte do corpo a alma se libertava das perturbações carnais já que o corpo escraviza a alma pelos sentidos, levando-a a decadência moral pela busca da concretização dos desejos e paixões.

Sócrates ${ }^{15,16}$ corroborava com o dualismo psicofísico, contudo não via o corpo como um obstáculo para a alma, mas sim uma possibilidade da alma fazer aquilo que desejava, praticar o pensamento, além de permitir as sensações. Afirmava que a alma dava vida ao corpo inanimado, assim, o corpo tornava possível a interpretação do querer da alma, passando de um estado de corpo-obstáculo para um corpo-possibilidade. Para Aristóteles ${ }^{15,16}$, o corpo e a alma são indissociáveis, pois um necessita do outro para sobreviver, pois formam uma unidade existencial e perfeita. 
Descartes $^{17}$ afirmava que 0 homem possuía duas dimensões, que 0 corpo era apenas uma matéria física que precisava da mente para poder compreender o mundo. Considerava a mente como a dimensão imaterial do homem sendo a parte responsável pelos pensamentos e controle do corpo. $O$ corpo seria apenas um condutor de estímulos do mundo exterior para a mente, que interpreta e reage às sensações. Sendo assim, o corpo é influenciado e comandado pela mente de forma a executar seus desejos. Para Descartes ${ }^{17} \mathrm{o}$ corpo nunca poderia ser visto apenas como uma máquina, pois isto trazia sentimentos negativos, de rejeição, como algo que poderia ser descartado quando não apresentasse boa funcionalidade como acontece nas indústrias.

O corpo não pode ser tratado como objeto e nem trocado por um novo, quando apresenta defeito. Pode ser, em alguns casos, "consertado" e cuidado de forma a reestabelecer suas funções normais, o homem ainda não tem a capacidade de substituir seu corpo por outro. Para Nietzsche ${ }^{18}$ (p. 196) o corpo é o início e o fim, "aquêle que está acordado e consciente diz: sou todo corpo e nada fora dêle.".

Diante da não comprovação científica da existência da alma até o momento, o mais sensato neste estudo é deixar o tema ainda restrito a filósofos e religiosos, e focar no corpo como algo real e palpável, pois para a ciência é o cérebro o responsável por todas as ações e reações no organismo humano. O cérebro é considerado um computador biológico central com inúmeras redes de bilhões de neurônios interligados que por meio de sinapses conduzem informações internas e externas para todo o corpo. Para Le Breton ${ }^{12}$ a existência a princípio será sempre corporal porque o corpo é o que se tem de real, concreto e palpável.

$\mathrm{Na}$ área da saúde o corpo sempre foi visto como algo que poderia ser estudado em três áreas principais: biológico, químico e psicológico, sendo passível de manipulação, alteração e controle. A medicina é guiada pelo pensamento de que é o cérebro o responsável por comandar o corpo biológico, por isto trabalhar a ideia de conservar e manter este corpo significa pensar na construção da identidade pela aparência, na interação deste corpo com o mundo exterior e em sua finitude ${ }^{19}$. 
A ciência diz que o corpo é um conjunto de sistemas, é sensível, instável e finito, isto significa então que ao longo do ciclo da vida apresenta defeitos e envelhece. Estas características despertam a importância deste corpo para a sobrevivência e também que este não deve ser desvalorizado e fragmentado em partes como está acontecendo no mundo moderno, os indivíduos estão sendo resumidos a olhos, boca, nariz, peitos, glúteos, braços e pernas como se cada pedaço fosse independente e alvo de mercadoria ou consumo.

A sociedade atual manipula as pessoas para que estas rejeitem a ideia de envelhecimento ou de aceitar qualquer forma corporal que esteja fora dos padrões estéticos impostos por ela. Que na visão de Debord ${ }^{19}$ o mundo vive um espetáculo onde as relações são medidas pelas imagens das pessoas e que $o$ individualismo e a busca pela visibilidade traz menos acesso ao outro. $O$ corpo tem sido usado como ferramenta para ascensão social e não como parte integrante da sociedade. Isto está fazendo com que pessoas fiquem doentes, com que a sociedade fique doente devido à superficialidade das relações baseadas na imagem corporal dos indivíduos.

O homem necessita entender que o corpo é fundamental para viver, para sentir e interagir socialmente, e para que isto ocorra este corpo precisa estar saudável e em plena funcionalidade para se fazer presente na vida social. Isto mostra que a felicidade, as sensações, os sentimentos, os desejos não tem origem apenas na contemplação das ideias, na razão e na moral como afirmam alguns pensadores, mas também que não se restringe a imagem corporal perfeita rotulada pela sociedade moderna e que existem variações de formas corporais que devem participar da sociedade de forma equânime ${ }^{19}$.

O corpo necessita estar saudável para interagir com o meio, e isto não significa obrigatoriamente estar dentro dos padrões estéticos sociais. Um corpo que não funciona de forma a satisfazer o indivíduo e ao outro pode adoecer de maneira biológica, mental e social. Partindo do aforismo "corpo são em mente sã" quando o corpo encontra-se saudável a mente fica livre para contemplar as ideias e assim controlar suas emoções e experimentar a felicidade ${ }^{15}$. Mas quando este corpo adoece, demonstrando vulnerabilidades, enfermidades, descontroles, não despertando paixões e desejos no possuidor 
do corpo e também no outro que o observa, torna-se um símbolo de fragilidade e até empecilho na relação corpo e sociedade.

Quando se fala em felicidade, sentimentos, comportamentos, satisfação e insatisfação, significa que para estudar o corpo deve-se contextualizá-lo com a ciência, a história e a cultura. Contudo, o tema construção corporal é bastante complexo e quanto mais se busca informações e conceitos, mais resistências e vácuos são descobertos, permitindo assim discursos subjetivos e pareceres não finalizados sobre o corpo ${ }^{20}$.

O corpo real, nada mais é que o corpo natural, aquele que se apresenta ao nascer, que representa o início da existência, formado por estruturas físicas e possuidor de características particulares. Contudo, diante da insistência e subjetividade é impossível não dar sentido ao corpo real utilizando o Simbólico, sabendo que este sempre terá o sentido Imaginário ${ }^{21}$.

Para Lacan $^{21}$ o corpo enquanto objeto de estudo e ensino deve ser analisado semelhantemente como uma criança que vê pela primeira vez seu reflexo no espelho e ao mesmo tempo vê o reflexo do adulto que a acompanha, e se encanta e passa a ter uma relação com a imagem, isto é o início da construção primordial do Eu. A imagem refletida desperta interesse em si mesmo e no outro, estas imagens auxiliam na construção da identidade por semelhança estrutural e também o despertar da libidinização.

A construção da imagem corporal fundamentada na imagem do outro permite uma dialética entre as pessoas, surgindo a atração, a fecundidade e até mesmo o surgimento de uma relação própria narcisista que é quando a imagem própria refletida desperta um fascínio ao sujeito ${ }^{22}$. O narcisista é extremamente vaidoso, insensível e apaixonado por sua imagem, em seu mundo não existe o outro, ele é soberano, autossuficiente e auto erótico, não consegue enxergar a beleza física do outro ${ }^{23}$.

A história de Narciso na sociedade moderna representa a individualidade, a negatividade, o auto centrismo, o quanto um indivíduo pode aprofundar em si mesmo, deixando de vivenciar relações com o outro. A vida 
do narcisista pode ser efêmera, porém estéril, isto torna o narcisismo uma conduta ou doença não benéfica ao indivíduo e a sociedade ${ }^{23,24}$.

A importância da imagem corporal tem aflorado gradativamente nos indivíduos com o passar do tempo, e nos dias atuais a busca pela imagem perfeita vem gerando frustrações e até mesmo doenças de origem psíquica. $O$ narcisismo é a busca por um corpo objeto que desperte desejo e que seja semelhante. O corpo inteiro ou as partes deste corpo devem proporcionar satisfação, a imagem perfeita passa a ideia de integralidade, plenitude, satisfação e torna-se um objeto de amor. Aparentemente o narcisista está alheio ao mundo ao seu redor, contudo existe uma relação de observação do outro para que se possa haver um investimento interno e imaginar o futuro. Isto permite no imaginário trazer o fim daquele corpo ainda em construção. Daí a importância da presença do outro na construção da própria imagem ${ }^{23}$.

Cultivar o corpo ideal em busca da beleza ideal é uma ilusão, pois o indivíduo passa a se ver e amar como um objeto que causa desejo e satisfação no outro, criando assim uma demanda ilusória de um modelo humano perfeito. E qualquer abalo a esta imagem acarretará imaginariamente uma exclusão deste indivíduo dos centros das atenções. Surgindo então a necessidade de renovação, alteração e modificação desta imagem com o intuito de permanecer satisfazendo o próprio ego e as necessidades do outro como admirador ${ }^{23,25}$.

O narcisismo se perpetuará enquanto houver a necessidade do indivíduo em se satisfazer com a existência do desejo do outro sobre a sua imagem. Renunciar ao narcisismo em uma sociedade narcisista não é uma tarefa fácil porque os indivíduos são criados para serem perfeitos e abrir mão da perfeição é modificar o julgamento crítico desenvolvido desde o nascimento, é substituir o imaginário pelo real ${ }^{24}$.

Em sua obra "O Estranho" Freud ${ }^{22}$ relata uma experiência própria vivida durante uma viagem, em que durante um movimento brusco do trem a porta do toalete se abre e aparece um senhor idoso, usando roupão e boné. Demorou alguns minutos para perceber que era sua imagem refletida no espelho, então 
confessou que não gostara daquela aparência, tomado de emoção considerou aquela imagem assustadora, angustiante e o nomeou de estranho.

Freud $^{22}$, então, começa a falar da estética, da beleza e das qualidades do sentir medo, horror e angústia do corpo e da imagem. Passou a estudar não a estética do que é belo, mas aquela que causa desconforto, aflição e malestar. O outro refletido no espelho que deveria ser conhecido e familiar, tornouse irreconhecível e estranho, ao ponto de perguntar: este sou eu? Eu sou este outro? Este outro sou eu? Em um mesmo corpo existe uma duplicidade, o Eu e o Outro. O corpo envelhecido traz maturidade, porém traz proximidade com a morte, o que era belo e prazeroso agora se converte em horror e próximo, este Outro deveria ter permanecido escondido e nunca ter se apresentado ${ }^{22,26}$.

Percebe-se nos discursos destes estudiosos do corpo que o ser humano apresenta características corporais semelhantes, mas que ao longo do tempo podem ser modificadas de acordo com as interferências internas e externas. Estas mudanças acontecem quando o indivíduo passa a reconhecer o contorno das multiformas corporais, das inúmeras faces e ter uma visão real do mundo e dos pontos de vistas, isto é, participar dos acontecimentos do ambiente externo, saber diferenciar o papel do corpo no contexto social, assim a construção corporal e da identidade se tornam mais reais e menos imaginárias ou vice-versa.

Estas mudanças acontecem de forma lenta e progressiva de acordo com as observações do sujeito em relação aos outros corpos e com o envelhecimento natural do corpo. Isto mostra que ao longo da vida existem perdas e ganhos neste corpo, as cicatrizes, as rugas, o ganho de peso, a flacidez, que são os registros do tempo. Muitas vezes o sujeito não aceita a imagem refletida deste corpo, o que traz tristeza, desprazer, insatisfação e vergonha, como relatadas por Freud. A busca pela mudança corporal a princípio tem finalidade de criar novas relações, despertar interesse e atenção e tentar manter uma convivência harmônica com os outros ou o Outro.

Não existe uma imagem corporal perfeita aos olhos de todos. Para determinar se um corpo é bonito e agradável é necessário que existam outros 
corpos constituídos de formas diferentes servindo assim de parâmetro para definir o que é um corpo saudável, feio, sensual, livre, flácido, reprimido, firme, natural, holístico, moderno, consciente, inteiro, repugnante, prazeroso, gordo, magro, atrativo ou repulsivo, isto significa comparar os corpos por meio do imaginário particular daquele que observa.

O corpo é arrumado e articulado para o desejo e prazer, sendo utilizado como uma forma dialética. $O$ indivíduo utiliza imagens próximas e que tenham significados positivos para a construção da sua identidade. Despertar o prazer também está associado ao tema corporeidade, a sexualidade está presente e é essencial na vida das pessoas em todo o ciclo da vida desde a infância até a velhice, englobando aspectos físicos, biológicos e emocionais ${ }^{27}$.

Está associada à afetividade entre os seres, e o corpo é o meio pelo qual a sexualidade pode ser expressa. Não se resume apenas aos órgãos genitais, mas pode ser demonstrada por olhares, gestos e comportamentos que despertam o prazer nas relações interpessoais. Contudo este tema é ainda tabu para uma sociedade que condiciona e educa os corpos, preconizando o que é correto, embora existam particularidades em cada corpo, no entanto 0 homem costuma fazer o que a sociedade impõe e deixa-se reprimir ${ }^{27}$.

A sexualidade é o manifestar corporal referente a uma energia com múltiplas dimensões, não devendo ser sinônimo de sexo. O corpo procura sensações profundas em busca do prazer, a sexualidade sempre foi um fascínio para o ser humano, pois representa felicidade pessoal e social. A ausência de sexualidade implica frustração e morte ${ }^{27}$. Em uma visão positiva a sexualidade representa fonte de saúde, boa forma, sucesso e beleza, centralização dos olhares, exacerbação da vaidade.

Estas visões diferentes dos corpos, independente se negativa ou positiva, deixou de ser uma mera preocupação com a saúde para se tornar uma preocupação com o visual, não somente no corpo, mas em todos os acessórios utilizados como roupas e adornos. $O$ valor da imagem produzida por este corpo e os sentidos incorporados vão assumindo um novo significado a cada fase histórica e cultural, podendo este ser moldado para corrigir eventuais 
defeitos. Foucault ${ }^{28}$ (p. 77) afirmava que "foi no biológico, no somático, no corporal que antes de tudo investiu a sociedade capitalista." Isto significa que os corpos não devem ser vistos como corpos finalizados e sim como um projeto que pode vir a ser.

A sexualidade recebe interferência de fatores externos e internos como medicamentos, mitos, tabus, cultura, fatores ambientais, convenções morais e éticas, alterações psicológicas e doenças crônicas, incluindo a obesidade. A repressão da sexualidade pode acarretar baixa autoestima, isolamento, insatisfações e frustrações em diversas áreas. O corpo pode expressar sentimentos, prazer, medos e insatisfação sem que haja comunicação verbal. A postura corporal pode indicar aceitação ou não aceitação em relação ao outro. A sexualidade é construída com a estimulação dos corpos, pela incitação do prazer, do controle e dos reforços ${ }^{29}$.

Para algumas sociedades os indivíduos podem expor seus corpos e exalar sua sensualidade e sexualidade, já em outras não. Isto demonstra a profundidade das questões que envolvem a construção corporal e a relação direta desta com a cultura. A sociedade consegue moldar os corpos de acordo com suas leis e costumes. Segundo Porto ${ }^{30}$ os corpos quando materializados expressam o molde cultural da sociedade e refletem a forma como os sujeitos incorporam os estímulos do mundo exterior. A sociedade é formada pela associação de corpos, quando estes corpos não estão de acordo com os marcadores sociais, a própria sociedade regula e orienta sobre a necessidade de intervenção corpórea com o objetivo de moldar o corpo de forma a produzir prazer e afasta-se da dor.

O corpo nunca se apresenta de forma singular, a sua forma está associado à dinâmica social por meio de apropriação de comportamentos e atitudes e assim adaptando seu corpo biológico. Segundo Mauss ${ }^{27}$ o corpo expressa significados e tradições em uma cultura por meio de gestos corporais que passam de geração para geração. O corpo é construído por meio de técnicas de educação para direcionar o uso adequado do corpo e manter as relações sociais. 
É a sociedade que determina a técnica a ser utilizada na educação do corpo podendo ser utilizado as técnicas de educação de imitação prestigiosa (quando alguém se espelha em uma pessoa que tem prestígio na sociedade); educação sangue-frio (quando alguém permite ser controlado); e a educação de interdição (quando há impedimento do uso de determinado objeto, exposição de parte do corpo ou comportamento), isto significa que a construção corporal e os gestos corporais não estão em campos opostos e compreendem tanto o biológico, o social e o cultural, tudo é uma questão de educação ${ }^{27}$.

A corporeidade analisa a forma corporal, mas também as palavras, os gestos, os olhares e as expressões corporais. Ela reconhece que o corpo é um meio de linguagem nas relações, assim como nomeá-lo de normal ou anormal, de belo ou feio. São estas impressões externas e internas que despertam o interesse de observação corporal, pois pelos corpos se constrói ou reconstrói uma história. Daí, a importância da simbologia do corpo não somente como biológico, mas como um corpo social que pode ser dividido em classes ou grupos sociais e estes deixam marcas nestes corpos que podem causar apreço ou repúdio ${ }^{30,31,32}$.

O corpo que não desperta desejo se torna uma barreira impedindo as relações sociais. Para modificar esta percepção de que os corpos diferentes do padrão social são anormais e devem ser excluídos, é necessária uma reflexão ética, iniciando pela ideia de que o mundo é plural assim como os corpos. Deve haver uma aproximação dos discursos da ciência e de outras áreas que estudam os corpos de forma a minimizar ações extremistas de corpos contra corpos e potencializar as relações, assim eliminando a idolatria de certos corpos.

Estas reflexões são úteis para alertar as pessoas que interagem e trabalham com os seres humanos, principalmente profissionais de saúde, que cuidam e tratam da saúde de seus corpos. É importante saber que trabalhar com o corpo é também tentar entender a cultura impressa em cada corpo. Portanto, estudar o corpo é estudar a sociedade da qual esse corpo faz parte, é tentar entender a existência da aceitação ou não aceitação deste corpo. É 
buscar explicações para a discriminação e estigmatização social, familiar e conjugal que levam ao adoecimento do corpo principalmente porque os relacionamentos são baseados em afetos, carinho e aceitação do outro. Isto significa a prática de uma visão e reflexão ampliada, significa a existência da pluralidade corporal e diferentes interpretações sociológicas.

Algumas doenças do corpo físico podem ser reflexos de um ambiente social opressor, afirmação já aceita pelas ciências biológicas tradicionais. Claro que não são todas as doenças originadas pelo desequilíbrio social, mas também ambiental que independem do querer do indivíduo e da sociedade. Exemplo disto são os vírus, bactérias e fungos que estão presentes no ambiente que podem provocar doenças até mesmo mortais, além da predisposição genética. É imperativo que a ciência se aproxime mais das ideias que relacionam a parte orgânica da parte subjetiva do corpo, abrindo assim novos horizontes nas ciências modernas ${ }^{33}$.

As pessoas estão acostumadas ir ao médico quando estão doentes fisicamente. Após a avalição médica exames são solicitados e se possível prescritos medicamentos para o tratamento, assim ainda acontece à relação médico-paciente nos dias de hoje. Lentamente esta relação vem sendo modificada devendo o paciente ser visto como o todo e não em partes, por isto a necessidade de diversos profissionais ${ }^{34}$.

Os profissionais de saúde não podem mais ignorar que existem casos em que somente a terapêutica médica não consegue tratar doenças. Desde 1983 a OMS tem discutido questões de como lidar com a dimensão "não material" na assistência à saúde. Para a OMS a visão mecanicista dos pacientes como sendo apenas um corpo material, não é mais satisfatória. Em 1988 a OMS $^{35}$ (p.8) por meio de resolução alterou o conceito de saúde para "um estado dinâmico de completo bem-estar físico, mental, espiritual e social e não meramente a ausência de doença ou enfermidade".

A partir deste momento a OMS tem avaliado e aceitado argumentos de estudos envolvendo a psiconeuroimunologia que sugerem que dimensões psicossociais afetam a qualidade de vida causando desesperança, insatisfação, isolamento e renúncia deixando assim o organismo fragilizado, 
ficando então susceptível a doenças, contudo as reações psicossociais podem ter efeitos positivos por meio da esperança, satisfação, bom humor, enfrentamento e apoio social podendo restaurar o doente.

Segundo a $\mathrm{OMS}^{35}$ (p.4) qualidade de vida "é a percepção dos indivíduos de sua posição na vida no contexto dos sistemas de cultura e de valores nos quais ele vive e em relação aos seus objetivos, expectativas, padrões e preocupações".

Para $\operatorname{Ross}^{36}$ quando a dimensão não material é trabalhada as pessoas são mais saudáveis, menos doentes, mais tranquilas e menos viciadas, pois seu sistema imunológico deprime menos e o corpo adoece menos. Trabalhar o subjetivo significa permitir adentrar em novos caminhos da terapêutica, assim como já existem outras práticas não convencionais aceitas como a acupuntura, homeopatia, fitoterapia e musicoterapia.

Segundo Borges et $a l^{34}$ muitas doenças crônicas que não respondem ao tratamento com fármacos podem não ter origem diretamente biológica por isto é necessário uma sensibilidade e capacitação para entender e tratar estas manifestações, e a ajuda de um psicólogo ou psiquiatra é muito importante. Não basta medicalizar e não basta psicologizar, a mente e o corpo devem ser tratados de forma conjugados.

Abordar o histórico de doença e relacionamento com a família, com amigos e com a sociedade é fundamental para descobrir se aquela determinada doença não é um reflexo de uma mente oprimida. A mente se comunica com o corpo e tem poder sobre este e sobre sua saúde, contudo o corpo também pode afetar a mente porque estão interligados. Quando a mente adoece, ela tem a necessidade de manifestar no corpo sua dor, e é por meio da psicossomatização do problema que isto acontece, nada mais é que usar o corpo como um veículo de comunicação de que algo na mente não vai bem e envolve mecanismos de interação entre a dimensão mental e dimensão corporal $^{37,38}$. 
O adoecer psicossomático pode significar carência emocional e relacional, de acordo com as experiências vividas o corpo vai sendo moldado fisicamente e emocionalmente, se retraindo, se expandindo, condicionado ou disciplinado, o corpo traz em seu histórico todos os conflitos emocionais e usa uma linguagem própria para transmitir estas experiências, como, os movimentos corporais, a forma e postura corporal, a fala, o tom de voz, até mesmo a maneira de se vestir. A psicoterapia é usada para libertar os corpos por meio de trabalhos que expressem emoções, abrem a mente, intensificam o prazer e tentam desbloquear e ampliar a consciência ${ }^{38}$.

A manifestação corporal é um reflexo da mente e vice-versa, toda doença tem uma fala, uma maneira peculiar de manifestação, uma simbologia para se expressar. Não se pode tratar uma doença somente como psicossomática ou orgânica, pois elas estão interligadas a um único corpo. A saúde mental e a saúde corporal devem ser tratadas com a mesma importância e em conjunto ${ }^{38}$.

Hoje uma das doenças que mais chamam atenção após a depressão é a obesidade. A pessoa obesa não pode ser vista somente como um distúrbio glandular. Quando começam a ser tratados por uma equipe multidisciplinar observa-se que a depressão e ansiedade estão presentes na maioria dos casos, o que indica uma fome física associada a uma fome psíquica. A fome psíquica provocada por angústia, tristeza, medo e carência busca no alimento uma possível solução para tapar estas lacunas e sentimentos negativos na mente ${ }^{38}$.

Algumas enfermidades são consequência da resistência do corpo em relação aos desígnios da mente, diante deste conflito o corpo adoece. Os conflitos emocionais são responsáveis por $70 \%$ das enfermidades no ser humano. O campo da consciência emocional quando reprimido por não conseguir processar ou expressar as emoções começa a somatizar por meio de doenças. As emoções mais prejudiciais ao ser humano são o medo e a ausência de amor, o medo incontrolável que é o pânico pode afetar os rins, glândulas suprarrenais e os ossos, a energia vital é paralisada ${ }^{39}$. 
O ser humano deve se esforçar para conhecer seus limites, cuidar e tentar superar as emoções que destrói este corpo. Existem emoções que quando controladas passam de negativas para positivas, um exemplo é a raiva, ela quando dosada representa autoafirmação, defesa, justiça, mas quando em excesso, irrita, agride, incomoda e torna-se ódio, este sentimento chamado ódio afeta fígado, estômago e intestino e o sistema imunológico ${ }^{39}$.

A alegria e a felicidade suavizam as emoções, canaliza o que de bom o mundo e o corpo podem oferecer, mas a tristeza passeia por caminhos que pode chegar à depressão, que nada mais é que o descontrole interno psicofísico. Todas as emoções são positivas, o ato de reprimi-las e não as conhecer é o que as tornam negativas. As emoções fazem parte do ser humano por isto é importante compreender, transformar e canalizar estas emoções para que se tornem construtivas e não destrutivas. O próprio amor que a princípio é algo sublime e positivo, quando em excesso pode se tornar tóxico e destrutivo ${ }^{39}$.

Partindo destas ideias, os seres humanos podem construir saúde a partir de um corpo são e uma mente sã, contudo adoecer não é sinônimo de fracasso. A libertação dos sentimentos de solidão, vazio, angústia não se cura comendo exageradamente alimentos com excesso de gordura e carboidratos, 0 problema não deve ser solucionado somente de fora para dentro, mas de dentro para fora. A maior ansiedade vem do desejo de ser o que não somos, então surge a competitividade da perfeição, de ser o melhor, de possuir uma aparência que na verdade não é minha, mas é a que eu quero ter ou que querem que eu tenha, isto nada mais é que imitação ${ }^{38,39}$.

A felicidade deve ser percebida não como gozo, mas como integridade dos sentidos, para que a felicidade seja real, ela precisa transparecer na vida cotidiana. Deve-se nutrir a ideia de que a felicidade não está no que se tem ou em alguém, a maior ilusão das pessoas é achar que seus corpos não têm significados. O corpo não deve ser usado como objeto dos sonhos do outro, deve-se aceitar que existem corpos imperfeitos e diferentes, a não aceitação do próprio corpo é um sinal para que o outro também não o aceite. Por isto o cuidado com o corpo é fundamental para que haja uma boa relação entre o 
corpo e o mundo exterior, pois a imagem corporal refletida no espelho e apresentada no âmbito social deve agradar primeiramente ao indivíduo e consequentemente o outro ${ }^{39}$.

Um exemplo claro de construção e representação corporal que traz insatisfação pessoal e social em nossos dias é a imagem do corpo com obesidade mórbida, a negação e exclusão desta forma corporal trazem prejuízos físicos, psicológicos e sociais incalculáveis para o sujeito obeso por causa da discriminação e estigmatização. A pessoa obesa quando tem sua imagem corporal rejeitada pela sociedade da qual participa passa também a rejeitar seu próprio corpo, desprezando-o, não o reconhecendo como seu, não consegue mais se olhar no espelho, deixando de tocá-lo e não permitindo que o outro o toque reduzindo ou anulando assim qualquer interação social.

As pessoas com obesidade mórbida apresentam sentimentos negativos em relação à própria imagem corporal e isto afeta a saúde, a sexualidade e as relações interpessoais. Por isto muitos buscam a CBM não somente como um procedimento para perda de peso e solução para doenças crônicas físicas, mas doenças psicológicas e também problemas sociais, pois o excesso de peso traz insegurança e inibe o desenvolvimento social, o que acarreta isolamento por problemas psicossociais por isto o processo de CBM envolve acompanhamento psicológico e psiquiátrico. 


\subsection{EPIDEMIOLOGIA DA OBESIDADE EM ALGUNS PAÍSES DO MUNDO}

A palavra obesidade deriva do latim "obesus" em que "ob" significa muito e "edere" significa comer. O conceito de obesidade definido pela OMS e adotado também pelo Ministério da Saúde do Brasil (MS) ${ }^{41}$ (p.20) é "grau de armazenamento de gordura no organismo associado a riscos para a saúde, devido a sua relação com várias complicações metabólicas". A obesidade é uma doença que afeta todas as áreas da vida da pessoa de forma inexorável e continuada, provocando mudanças sistêmicas, anatômicas, funcionais, psicológicas e sociais. Em resposta às mudanças, surgem então as patologias correlacionadas que aumentam a taxa de morbimortalidade ${ }^{2,41}$.

Por muitos anos a obesidade foi vista e estudada como uma possível manifestação em consequência de alterações psicológicas, a somatização de conflitos internos tendo como busca para a solução a hiperfagia. Segal e Fandiño $^{42}$ relatam que as pessoas obesas que procuram tratamento para emagrecer são em sua maioria diagnosticadas com alterações psicológicas como depressão, psicopatologias alimentares e ansiedade. Existe um aumento da prevalência destes sintomas em obesos, não existe ainda uma comprovação de causa e efeito direto. De acordo com Fioravanti e Zorzetto ${ }^{43}$ os estudos atuais direcionam que a manutenção da obesidade também está associada a desarranjos genéticos e neurofisiológicos.

Por mais que as causas da obesidade estejam ligadas ao campo orgânico e seu tratamento direcionada à medicina tradicional por meio de uso de medicamentos e procedimentos médicos, o acompanhamento psicológico tem auxiliado no controle dos sofrimentos psíquicos que circundam a pessoa obesa. O trabalho psicológico com o obeso é direcionado para a relação do obeso com o corpo e que a noção de corpo ultrapassa um corpo meramente biológico.

Freud $^{44}$ não abordou a obesidade em seus estudos, porém, associava a relação corpo, comer e sexualidade ao analisar sintomas de histerias partindo 
da oposição entre corpo representado e corpo biológico. Também afirmava a existência de excitações bioquímicas, o organismo necessitava descarregar as suas excitações de prazer ou tensão, gerando assim uma compulsão em busca do prazer ou desprazer, daí a associação aos distúrbios alimentares ${ }^{45,46}$.

Existem várias formas da obesidade se apresentar: sobrepeso, obesidade central, abdominal, intra-abdominal, visceral, intra-visceral e Síndrome Metabólica (SM) que é o estágio mais grave da obesidade. A SM é um conjunto de fatores ou alterações que comprometem à saúde de um indivíduo e está associada à obesidade, são eles: hipertensão, alteração do colesterol, alterações glicêmicas ou Diabetes por resistência insulínica, triglicerídeos alterados. Quando três ou mais destes fatores estão presentes pode-se pensar em um diagnóstico para a SM, por isto a necessidade de acompanhamento por um endocrinologista ${ }^{47}$.

A fórmula do cálculo do IMC aceita em todo o mundo é a do matemático Lambert Adolphe Jacques Quételet (1796 - 1874) expresso pela fórmula matemática IMC=Massa/Altura ${ }^{2}$ (onde, o IMC é resultado da divisão entre 0 peso em quilogramas pela altura em metros ao quadrado), adotada pela Organização Mundial de Saúde em 1997 que divide a obesidade em três níveis $^{48,49}$. Somente é considerado obeso mórbido o indivíduo que apresenta IMC acima de $40 \mathrm{Kg} / \mathrm{m}^{2}$. Representação dos valores em Tabela 1 segundo classificação da OMS e em Tabela 2 a representação de outra classificação elaborada pela Sociedade Americana de Cirurgia Bariátrica e pela Federação Internacional da Obesidade que divide a obesidade em seis níveis, isto devido à evolução da doença que atinge IMC elevados. 
Tabela 1. Classificação da obesidade segundo a OMS.

\begin{tabular}{lc}
\hline \multicolumn{1}{c}{ CLASSIFICAÇÃO } & \multicolumn{1}{c}{ IMC } \\
\hline Abaixo do peso & $>18,5 \mathrm{Kg} / \mathrm{m}^{2}$ \\
Peso ideal & $18,6-24,9 \mathrm{Kg} / \mathrm{m}^{2}$ \\
Excesso de peso & $25,0-29,9 \mathrm{Kg} / \mathrm{m}^{2}$ \\
Obesidade Grau I & $30,-34,9 \mathrm{Kg} / \mathrm{m}^{2}$ \\
Obesidade Grau II & $35,0-39,9 \mathrm{Kg} / \mathrm{m}^{2}$ \\
Obesidade Grau III & $\geq 40,0 \mathrm{Kg} / \mathrm{m}^{2}$ \\
\hline
\end{tabular}

Fonte: Puglia, $2012^{49}$ (Adaptado).

Tabela 2: Classificação da obesidade segundo a Sociedade Americana de Cirurgia Bariátrica e pela Federação Internacional da Obesidade.

\begin{tabular}{lc}
\hline \multicolumn{1}{c}{ CLASSIFICAÇÃO } & IMC \\
\hline Obesidade pequena & $27,0-30,0 \mathrm{Kg} / \mathrm{m}^{2}$ \\
Obesidade moderada & $30,0-35,0 \mathrm{Kg} / \mathrm{m}^{2}$ \\
Obesidade grave & $35,0-40,0 \mathrm{Kg} / \mathrm{m}^{2}$ \\
Obesidade mórbida & $40,0-50,0 \mathrm{Kg} / \mathrm{m}^{2}$ \\
Superobesidade & $50,0-60,0 \mathrm{Kg} / \mathrm{m}^{2}$ \\
Super-superobesidade & $>60,00 \mathrm{Kg} / \mathrm{m}^{2}$ \\
\hline
\end{tabular}

Fonte: Puglia, 2012 ${ }^{49}$. (Adaptado).

Sendo que o IMC isoladamente não é considerado a forma mais exata para determinar obesidade e riscos, o médico especialista deve avaliar o indivíduo por meio de outros exames como: distribuição anatômica da gordura corporal - corpo androide e ginóide; características do tecido adiposo obesidade hiperplásica ou hipertrófica; medidas das circunferências; dobras 
cutâneas; pesagem hidrostática; Raios $X$ de Dupla Absorbância; Ultrasonografias, Ressonância magnéticas; bioimpedância e outros ${ }^{49-52}$.

Os dados epidemiológicos referentes à obesidade têm apresentado taxas crescentes de prevalência e incidência incluindo as comorbidades, o que tem preocupado órgãos de regulação da saúde no cenário nacional e internacional. A obesidade deixou de ser um problema apenas estético e passou a ser uma consequência de uma má nutrição do indivíduo, sendo responsável por 5\% (2,8 milhões por ano) das mortes mundiais ${ }^{53-55}$.

Nos Estados Unidos da América (EUA), 40\% da população já eram considerados obesos entre os anos 1960 e 1991, em 2007 já era a segunda causa de morte evitável. Em 2013 os americanos obesos representavam $31,8 \%$ da população. Na Inglaterra o número de obesos dobrou entre os anos 1980 e $1991^{55,56}$. No Canadá no ano de 2007, a população obesa correspondia a 36\%. Na França, no ano de 2006, 33\% (20 milhões) de pessoas apresentavam sobrepeso e 10\% (6 milhões) eram obesas. Até 2007 na Europa havia 14 milhões de crianças com excesso de peso e 3 milhões obesas. $\mathrm{Na}$ Argentina, 20,5\% da população eram obesos em 2007.

No Brasil em 2013, cerca de 17,5\% da população era obesa e 50,8\% estava acima do peso $0^{57,58,59}$. Conforme explica Stunkard ${ }^{50}$ e a $\mathrm{OMS}^{51}$ as crianças e adolescentes obesas serão adultos obesos em potencial por se tratar de uma doença de grande fator hereditário; caso não sejam adotadas medidas de controle, possivelmente desenvolverão obesidade na vida adulta.

Uma pesquisa recente realizada entre os anos de 1980 a 2013 pelo Instituto de Métrica e Avaliação para a Saúde (IHME) da Universidade de Washington, nos EUA, incluindo 188 países, incluindo o Brasil e publicada em 2014, considerada atualmente a pesquisa mais abrangente sobre obesidade e sobrepeso mundial, afirma que aproximadamente um terço da população mundial está obesa, uma em cada três pessoas estão obesas. O estudo concluiu que em 2013 a população obesa e com sobrepeso juntas somam 2,1 bilhões de pessoas (30\% da população mundial), em 1980 representavam 857 milhões. Entre 1980 e 2013 a obesidade e o sobrepeso, quando somadas 
aumentaram $27,5 \%$ entre os adultos e $47,1 \%$ entre as crianças. Mundialmente, os homens representavam $29 \%$ dos indivíduos obesos e com sobrepeso em 1980, alcançando 37\% em 2013, já as mulheres em 1980 eram 30\%, chegando a $38 \%$ em 2013. As crianças com obesidade e sobrepeso representavam em $2013,23,8 \%$, tendo um aumento de $50 \%$ em todo o mundo nestes 33 anos ${ }^{60}$.

Então, existem 640 milhões de adultos apresentando peso de obeso, isto significa que no mundo existem mais obesos que pessoas com baixo peso excessivo, o que não exclui e não ofusca problemas da desnutrição causada pela fome em alguns países mais pobres que merecem igual importância como problema de saúde pública. Nos últimos 40 anos o IMC acima de $30 \mathrm{~kg} / \mathrm{m}^{2}$ aumentou de 105 milhões em 1975 para 641 milhões em 2014. Um em cada dez homens e uma em cada sete mulheres estão obesos. Houve uma redução da taxa e sobrepeso de $51 \%$ para $40 \%$, contudo a migração ocorreu para a faixa da obesidade e não para a normalidade de peso ${ }^{60}$.

Ainda segundo o estudo nenhum país apresentou declínio do quadro de obesidade nos últimos 33 anos, pelo contrário, cresceu 70\% em três décadas. Isto significa que caso não sejam tomadas medidas urgentes para combater a obesidade, a expectativa é que este número cresça de forma constante e atingirá também os países de baixa e média renda. A maior parte dos obesos em todo o mundo, isto é $50 \%$ está concentrada em 10 países: EUA que lidera a lista, seguido da China, Índia, Rússia, Brasil, México, Egito, Alemanha, Paquistão e Indonésia. Os dados mostram que a obesidade já se tornou uma epidemia, com dimensões globais, alcançando pessoas de todas as idades. Os pesquisadores esperam que os dados apresentados despertem a atenção dos gestores de cada país e que sejam adotadas medidas de controle desta doença que traz consigo um catálogo de doenças associadas como cardiovasculares e diabetes ${ }^{60}$. 


\subsubsection{Obesidade no Brasil}

Surpreendentemente no Brasil, as doenças consideradas das classes "pobres" associadas à desnutrição e falta de higiene, como a tuberculose, doenças parasitárias, avitaminoses, diarreias e outras, estão sendo ultrapassadas epidemiologicamente por doenças metabólicas associadas à obesidade como diabetes, hipertensão arterial, aterosclerose e doenças cardiovasculares ${ }^{61}$.

Isto tem ocorrido devido às mudanças políticas e econômicas que têm favorecido as classes mais vulneráveis. Então, significa que estas classes estão aos poucos fazendo parte das estatísticas no quadro de obesidade devido à mudança do padrão econômico e consequentemente do padrão alimentar, estes deixaram de consumir frutas e leguminosas passando a consumir alimentos gordurosos e açucarados, característica comum em países em desenvolvimento ${ }^{61,62}$.

Até uma década atrás o Brasil discutia e focava suas ações em programas de combate à fome, tendo um dos mais importantes programas como referência "O Fome Zero", pois a fome ainda é um grande problema em muitos países, devido à má distribuição de renda e de alimentos ${ }^{63}$. A produção mundial de alimento é suficiente para alimentar todas as pessoas do planeta, acabando assim com o problema da fome, toneladas de comidas são descartadas - desperdícios - enquanto muitos comem em excesso outros procuram em lixeiras o mínimo para as necessidades básicas diárias.

Segundo Relatório Mundial da Fome divulgado por meio da Organização das Nações Unidas para a Alimentação e a Agricultura (FAO) os dados mostraram que aproximadamente 854 milhões estão subnutridas no mundo, 300 milhões de crianças passam fome e 25 mil pessoas morrem por dia em consequência da fome ${ }^{64,65}$. Do outro lado, em via de mão dupla, a obesidade com suas doenças agregadas matam milhares de pessoas por dia, um número maior que somados a subnutrição e morte por fome. O número exato não pode ser descrito, pois as declarações de óbitos não trazem a obesidade como diagnóstico principal da causa morte, sendo indicados doenças relacionadas à 
obesidade. Somente no ano de 2010 cerca de 3 milhões de pessoas foram vítimas de obesidade mórbida no mundo, aproximadamente 8.220 mortes por dia, um número três vezes maior que mortes por fome ${ }^{60}$.

Dois extremos que geram consequências para o desenvolvimento físico, psicológico e social. Contudo, a obesidade tem se agravado em proporções maiores e atinge também estes países onde a fome está presente, sendo gerados então inúmeros problemas de saúde e consequentemente aumento dos gastos nos serviços de saúde ${ }^{66}$. A obesidade tem adentrado e atingido tribos indígenas brasileiras, índios Xavantes do Mato Grosso (Sangradouro e São Marcos) estão apresentando IMC elevado e casos de diabetes devido à transição nutricional ${ }^{67}$.

No Brasil, entre os anos de 1974 e 1989 a maioria da população estava em um patamar considerado abaixo do peso ideal ${ }^{68}$. A população brasileira entre 2006 e 2009, contudo, já era composta por 3\% de obesos mórbidos, sendo liderada por maioria feminina, e $40 \%$ da população já apresenta indícios de excesso de peso ${ }^{69}$. Entre os anos de 1970 até 2009 houve um aumento considerável no número de obesos e pessoas com excesso de peso no País, segundo informações do Instituto Brasileiro de Geografia e Estatística (IBGE) 2008-2009, uma relação entre a obesidade e a menor escolaridade tem sido observada no Brasil e em outros países ${ }^{58,68,70}$. Em 2011 a população com obesidade e sobrepeso passou para 48,5\% segundo relatório da Vigilância de Fatores de Risco e Proteção para Doenças Crônicas por Inquérito Telefônico (Vigitel) $^{71}$, os dados foram coletados em 26 capitais brasileiras e no Distrito Federal.

O MS ainda afirma que poucos são os casos de obesidade por influência de fatores genéticos, os fatores extrínsecos são os maiores causadores da obesidade, em consequência da globalização que altera a vida social do indivíduo e apresenta determinantes diferentes como urbanização, transporte, comunicação, nutrição, alimentação, trabalho, escola, lazer e gasto de energia. Diante dos dados apresentados nas pesquisas anteriores a 2008 que já indicavam o aumento da obesidade, o MS reforçou as estratégias de prevenção e combate contra a obesidade, com planos de construção de 
academias populares e orientação nutricional nas escolas públicas. Em 2010 foi elaborado o Plano de Ação Estratégica para o Enfrentamento das Doenças Crônicas Não Transmissíveis (DCNT) para ser executado a partir de 2011 e alcançar resultados satisfatórios até 2022 tendo como meta a redução de mortalidade de indivíduos por DCNT no mínimo em $2 \%$, sendo que a OMS ratificou este projeto e aconselhou que as metas chegassem à redução de pelo menos $25 \%$ em todo o mundo ${ }^{71}$.

Uma nova pesquisa nacional foi realizada via telefone nas 26 capitais brasileiras incluindo o Distrito Federal, entre os anos de 2006 e 2012 para avaliar o índice de obesidade da população em cada estado, os resultados foram divulgados em 2013. Foi constatado que em seis anos não houve recuo nos dados e sim progressão numérica, o aumento no índice de obesidade dos brasileiros corresponde a 54\% neste intervalo de tempo, os obesos representavam $17,1 \%$ da população brasileira no ano de 2012 , dado este que em 2006 os obesos correspondiam a $11,6 \%$ da população ${ }^{72}$.

Os dados revelaram ainda que mais da metade da população brasileira estava acima do peso. Sendo que os adultos acima de 18 anos que apresentam IMC igual ou maior que $25 \mathrm{Kg} / \mathrm{m}^{2}$ correspondem a $51 \%$ da população, deste resultado a maioria eram homens. Porém, quando os resultados são correspondentes a obesidade os dados se invertem, as mulheres são mais obesas, representando $17,7 \%$ enquanto os homens representam 16,6\%. Outro fator que interfere no índice de obesidade é a escolaridade, pessoas que possuem até oito anos de estudo representam $21,7 \%$, os que possuem até 12 ou mais representam $14,4 \%{ }^{72}$.

Em 2013 o Distrito Federal ocupava a quarta posição em relação ao menor índice de obesidade em adultos no Brasil o que corresponde a 14,9\% da população brasiliense, e ocupava a mesma posição em relação ao percentual de sobrepeso que representa $46 \%$. Sendo os homens ainda maioria nos dois casos. Em 2007 segundo pesquisa do MS a população com obesidade no Distrito Federal era de 10\%, comparado aos dados atuais houve um aumento de cinco pontos percentuais ${ }^{72}$. Em 2014 o Distrito Federal ocupa o sétimo lugar 
com menor índice de obesidade masculina e o quinto lugar em menor índice de obesidade feminina ${ }^{73}$.

Os dados mais recentes do MS por pesquisa Vigitel realizada em 2014 e divulgada em 2015, mostram que em nove anos (entre 2006 e 2014) o número de brasileiros com excesso de peso aumentou de 43\% para 52,5\%. Em 2013 eram quase 25 milhões de obesos, representando 18,9\% da população. Os homens ainda são maioria correspondem a $56,5 \%$ enquanto as mulheres $49,1 \%$. A prevalência é maior entre a idade de 35 e 64 anos, principalmente em indivíduos com menor escolaridade (menos de 12 anos de estudo). Nos últimos três anos (entre 2012 e 2014) não houve um crescimento acentuado da obesidade, porém estes já representam $17,9 \%$ da população, destacando as cidades de Florianópolis com o menor índice enquanto Campo Grande lidera com o índice maior. No Brasil as doenças crônicas, incluindo as associadas a obesidade, correspondem a $72 \%$ dos óbitos ${ }^{73}$.

O número de obesos mórbidos praticamente dobrou em sete anos no Brasil, saindo de 3,5 milhões, em 2007, para 6,8 milhões, em 2014 representando $3,6 \%$ da população, o que é considerado uma grande demanda para o número de cirurgias realizadas no país, em 2014 foram realizadas 88 mil cirurgias de redução de estômago, um número ainda considerado pequeno devido falhas de estrutura e atendimento, o que praticamente levam os profissionais de saúde a escolher os pacientes com prioridade máxima e aumenta a fila de espera, os custos com a obesidade no Brasil representa $2,4 \%$ do Produto Interno Bruto $(\mathrm{PIB})^{73}$. A seguir em Quadro 1 dados da prevalência da obesidade mórbida por região no Brasil entre 1974 a 2003. 
Quadro 1. Prevalência da obesidade mórbida no Brasil por distribuição regional da população entre os anos 1974 a 2003.

\begin{tabular}{|lllll|}
\hline REGIÃO & $\begin{array}{l}\text { ANO 1974- } \\
1975 \text { (*ENDEF) }\end{array}$ & $\begin{array}{l}\text { ANO 1989 } \\
\text { ('PNSN) }\end{array}$ & $\begin{array}{l}\text { ANO 2002- } \\
2003 \\
\text { ( }{ }^{*} \text { POF) }\end{array}$ & $\begin{array}{l}\text { AUMENTO } \\
\text { EM \% entre } \\
1974 \text { a 2003 }\end{array}$ \\
\hline NORTE & $0,10 \%$ & $0,37 \%$ & $0,51 \%$ & $410 \%$ \\
NORDESTE & $0,05 \%$ & $0,26 \%$ & $0,43 \%$ & $760 \%$ \\
SUDESTE & $0,20 \%$ & $0,33 \%$ & $0,77 \%$ & $285 \%$ \\
CENTRO- & $0,12 \%$ & $0,48 \%$ & $0,75 \%$ & $120 \%$ \\
OESTE & $0,34 \%$ & $0,25 \%$ & $0,49 \%$ & $308 \%$ \\
BRASIL & $0,18 \%$ & & & $255 \%$ \\
\hline
\end{tabular}

*ENDEF - Estudo Nacional de Despesa Familiar; * PNSN - Pesquisa Nacional de Saúde e Nutrição; *POF - Pesquisa de Orçamentos Familiares. Fonte: Oliveira, $2013^{74}$.

Os dados mostram crescimento acelerado em todas as regiões, destacando a região sudeste com maior percentual e a região nordeste que sempre foi referência em índices elevados de desnutrição, agora apresentando evolução rápida em obesidade mórbida em apenas três décadas. Sendo que entre 1974 a 2003 o sexo feminino apresentou aumento de obesidade mórbida de $197 \%$ e o sexo masculino de $700 \%$. O ano de 1974 foi escolhido por ser 0 ano em que ocorreu a primeira pesquisa familiar no Brasil em que incluiu peso e altura da população.

Uma pesquisa do IBGE em 2010 apresenta uma estimativa de que em dez anos o Brasil terá índices de obesidade iguais aos dos EUA, pois já apresenta fenômeno com contornos de epidemia. Caso não haja intervenção deste fenômeno em 2030 a população de obesos mórbidos será de três bilhões no mundo ${ }^{72,75,76}$.

Para combater e tratar a obesidade o MS regulamentou estratégias por meio de uma Portaria de $n^{0} 425 / 2013^{77}$ que estabelece as técnicas, normas e 
critérios para o serviço de assistência de alta complexidade ao indivíduo com obesidade, incluindo a cirurgia de redução de estômago e suas indicações. Pois o maior objetivo do tratamento do obeso não é simplesmente 0 emagrecimento e sim a redução da morbimortalidade associadas à obesidade.

Quando o Estado resolve investir na prevenção, promoção e tratamento da obesidade, ele deve ter o cuidado em não agir de forma a levar o indivíduo a pensar que é responsável diretamente pela doença (vitimização), pois existem condicionantes e determinantes do comportamento humano que influenciam no aparecimento da obesidade, e o Estado é um dos corresponsáveis por permitir ambientes favoráveis ao desenvolvimento da doença.

Por isto a Política Nacional de Alimentação e Nutrição e a Política Nacional de Promoção da Saúde faz parte da estratégia do governo para implantar a prática de alimentação saudável e mudança de comportamento que colaboram para diminuir a obesidade ${ }^{78}$. O profissional de saúde deve trabalhar a educação em saúde de forma a não culpar o indivíduo e não restringir apenas a alimentação, mas influenciá-lo a adquirir bons hábitos e mostrar que o excesso de peso traz consequências danosas ao organismo. 


\subsection{CIRURGIA BARIÁTRICA E METABÓLICA (CBM)}

Com o aumento do número de obesos mórbidos e comorbidades relacionadas, o fenômeno conhecido como "globesidade" ${ }^{1}$ passou a despertar atenção dos estudiosos. A medicina então por meio de pesquisas e experimentos avançou bastante em busca da cura da obesidade por representar grande ameaça para a saúde das populações ${ }^{48}$.

Por muitos anos o combate à obesidade se deu por tratamentos conservadores, o que para alguns era o suficiente para emagrecer, para outros apenas uma fórmula paliativa que ao passar do tempo não mantinha o efeito desejado. Então, quando a obesidade chega a um nível gravíssimo denominado de obesidade mórbida (IMC > que $40 \mathrm{~kg} / \mathrm{m}^{2}$ ) passando a comprometer a vida do indivíduo, a intervenção cirúrgica é possivelmente a única solução ${ }^{48,79}$.

O que se denomina de Cirurgia Bariátrica e Metabólica (CBM) ou Gastroplastia é na verdade um conjunto (técnicas) invasivas, procedimentos médicos que tem como objetivo inicial a redução do estômago ou intestino, isto é, redução da capacidade de armazenamento e da capacidade de absorção dos alimentos, o objetivo final é a perda de peso e a redução ou cura das doenças correlacionadas. As primeiras experiências com a cirurgia foram realizadas na década de 1950, assim com o passar do tempo outras técnicas foram criadas e aprimoradas ${ }^{80,81,82}$.

O estômago e intestino passam por modificações anatômica e funcional, conforme a etiologia da palavra "Gastroplastia" que tem origem grega "gaster, gastros," em português referente a ventre ou estômago e origem do latim "plasticus" ou do grego "plásticos" que significa "plástico" ou "plástica" algo capaz de ser moldado, modelado $83,84$.

Até 2004 a nomenclatura era Cirurgia Bariátrica, a partir de 2005 a nomenclatura foi modificada, incorporando-se a palavra "metabólica" pela importância da cirurgia em corrigir, controlar e curar comorbidades, alterando o

\footnotetext{
${ }^{1}$ Terminologia criada pela OMS para qualificar a obesidade como epidemia decorrente principalmente do fenômeno Globalização.
} 
metabolismo do indivíduo submetido ao procedimento. Hoje a correta pronúncia é "Cirurgia Bariátrica e Metabólica" conforme a Sociedade Brasileira de Cirurgia Bariátrica e Metabólica (SBCBM) ${ }^{83,84}$.

É um procedimento complexo, porém está se expandindo rapidamente, de forma que muitas pessoas portadoras de obesidade mórbida estão tendo acesso. Contudo, existem normas e leis que regulamentam o procedimento, como, IMC igual ou acima de $40 \mathrm{~kg} / \mathrm{m}^{2}$, ser obeso mórbido e ter sido submetido a outros tratamentos conservadores sem resultado positivo por pelo menos dois anos ${ }^{85,86}$.

As primeiras técnicas surgiram nas décadas de 1950 e 1960, em 1954 os médicos Kremen e Liner realizaram a primeira cirurgia de redução de estômago, o procedimento consistiu em retirar $90 \%$ da porção proximal do intestino delgado (jejuno e íleo) e desviar a porção restante (by-pass) "desvio" tendo como resultado má absorção dos alimentos e eliminação de fezes gordurosas. Em 1963, outro cirurgião Dr. Payne realizou um procedimento (denominado Cirurgia de Payne) em que se desviavam dois segmentos, um do intestino delgado e um do intestino grosso (jejuno-colônico). Estes dois procedimentos foram proscritos por causar complicações graves como Insuficiência Hepática, Cirrose, Nefropatias, Artrite, alterações metabólicas e diarreias agudas ${ }^{85,86}$.

Em 1982 o Dr. Edward Mason, considerado o pai da cirurgia da obesidade moderna, criou uma nova técnica Gastroplastia Vertical com Bandagem (GVB) método com poucas complicações e baixa mortalidade. Com uso de um anel de contenção, apenas isolando por meio de grampeamento parte do estômago sem ressecção, não havia alteração intestinal. Na década de 90 outras técnicas foram surgindo, isoladamente ou associadas. O cirurgião colombiano Rafael Capella utilizou dois mecanismos, restrição alimentar por redução do estômago e má absorção por retirada de um metro de intestino delgado, este procedimento foi denominado de Cirurgia de Capella ${ }^{86,87}$.

Ainda nos anos 1980 o Dr. Mal Fobi aperfeiçoou a técnica de Capella isolando $96,5 \%$ do estômago e utilizando apenas 2 metros do intestino, um anel de inelástico de contenção ainda era utilizado. Este procedimento foi 
denominado de Fobi-Capella (técnica mista Bypass Gástrico em Y de Roux), sendo a técnica mais utilizada no mundo até os dias de hoje por apresentar menos morbimortalidade e boa eficácia, porém o anel foi abolido por causar vômitos constantes e necessidade de nova cirurgia para retirá-lo. A nova técnica divide o estômago em dois segmentos por meio de grampeamento, a porção menor se torna o novo estômago e a porção maior isolada, um desvio intestinal também é realizado ${ }^{86,87}$.

O procedimento de cirúrgica bariátrica começou a ser desenvolvido e realizado no Brasil em 1970 no Hospital das Clínicas de São Paulo pelo médico cirurgião Arthur Belarmino Garrido Junior que adotou a cirurgia Fobi-Capella nos anos 1990 estimulando o abandono da técnica de Mason (Gastroplastia vertical com anel). Com o decorrer do tempo, outros cirurgiões de diferentes estados do país estimulados e orientados pelo doutor Garrido Junior começaram a se especializar e realizar a cirurgia devido à mobilização da comunidade médica e a grande demanda de pacientes obesos ${ }^{86,87}$.

Existem diferentes modalidades do procedimento, cada uma apresenta técnicas e mecanismos de funcionamento pós-cirurgia diferenciados, sendo procedimentos restritivos ou disabsortivos, o tamanho do estômago fica reduzido entre 50 e $120 \mathrm{ml}$ e o tamanho do intestino também é reduzido. Ainda existem procedimentos mistos (associação de técnicas). No Brasil apenas quatro modalidades são aprovadas pelo CFM (Bypass $Y$ de Roux; Banda Gástrica Ajustável; Gastrectomia Vertical e Duodenal Switch) ${ }^{9}$.

A perda ponderal está associada ao procedimento adotado, podendo atingir entre 20 a $90 \%$ do peso inicial. A perda excessiva de peso entre 74 a $91 \%$ do peso inicial traz riscos à saúde pela má absorção, são eles, edema abdominal, diarreias, flatulência, desnutrição, anemia ferropriva, doenças ósseas, formação de cálculo biliar, úlceras intestinais devido ao desvio das enzimas, fluxo sanguíneo aumentado no período menstrual, osteoporose, deficiências de vitaminas e minerais ${ }^{82,88,89}$.

Algumas técnicas adotadas em outros países não foram aprovadas pelo CFM por mostrarem dados preocupantes sobre desenvolvimento de algumas doenças ou complicações metabólicas e nutricionais pela falta de vitaminas e 
minerais, caso não seja rigorosamente suplementados ${ }^{89}$. No Brasil $75 \%$ das cirurgias são pelo método Bypass, por ser segura e eficaz. Bypass é uma palavra de origem inglesa que significa contornar, desvio, caminho alternativo, passagem secundária. O paciente tem perda corporal de 40 a $45 \%$ do peso inicial. Contra-indicada em pessoas com doenças pulmonares graves, insuficiência renal, lesão acentuada do músculo cardíaco e cirrose hepática $88,90,91,92$.

Algumas técnicas não cirúrgicas são utilizadas para auxiliar no emagrecimento, como o balão intragástrico (método terapêutico auxiliar para preparo pré-operatório) conforme a Resolução $1.942 / 10^{9}$, porém ainda não coberto pelo Sistema Único de Saúde (SUS). Outro procedimento ainda em fase de pesquisa clínica é o "Marcapasso Gástrico". Um eletrodo é implantado na parede externa do estômago, que provoca saciedade precoce devido a estímulos elétricos contínuos, o procedimento é pouco invasivo, não altera a anatomia gastrointestinal, não demonstra complicações, e a perda de peso é de aproximadamente $15 \%$ e se mantém em longo prazo ${ }^{74,93,94}$.

Existem outras técnicas como, técnica de Wittgrove e Clark, Técnica Dr. Domene, Técnica Dr. Sérgio Santoro, Técnica Dr. Ludovico Interposição lleal, Técnica Dr. Lazzarotto. As técnicas restritivas e as mistas são as mais praticadas, contudo existem estudos científicos em desenvolvimento com 0 objetivo de desvendar as respostas neuroendócrinas, para evitar cirurgias radicais e que os procedimentos tenham resultados mais fisiológicos com menos complicações. O objetivo principal é diminuir a produção de hormônios no estômago e intestinos que regulam o apetite, pois pessoas obesas não tem megaestômagos, os estímulos hormonais que são desregulados, estas cirurgias são denominadas de "Cirurgias Adaptativas e Neuroendócrinas" ${ }^{\text {"3, }}$ 94,95 .

Um novo procedimento denominado Embolização Arterial Bariátrica (Bariatric Artery Embolization - BAE) ainda em fase experimental em seres humanos desde 2013 tem como objetivo principal reduzir a sensação de fome e perda de peso pessoas com IMC igual ou acima de $40 \mathrm{~kg} / \mathrm{m}^{2}$, isto é, com obesidade mórbida. A técnica consta da introdução de um cateter arterial inserido no pulso do paciente até atingir a artéria gástrica esquerda que irriga o 
fundo do estômago (onde é produzido a grelina). Neste ponto, grânulos microscópicos são injetados para bloquear a passagem de sangue causando uma isquemia local diminuindo os níveis de grelina circulante, consequentemente reduzindo a sensação de fome. Comparado com a CBM tradicional poderá ser evitado o ato cirúrgico e riscos envolvidos, a diminuição do estômago, o desvio do trânsito intestinal, os desconfortos intestinais, malestar e deficiências nutricionais ${ }^{96}$.

A BAE está sendo considerado mais seguro que as técnicas bariátricas atuais por oferecer um nível de segurança maior, sendo minimamente invasivo e podendo ser realizada em ambiente ambulatorial com duração de uma hora. A busca por novas técnicas tem o objetivo de aumentar o tempo de perda de peso, para que esta seja mais duradoura. Esta técnica encontra-se na quarta fase e tem apresentado resultados positivos e sem efeitos colaterais significativos, sendo que $80 \%$ dos participantes apresentaram perda do peso inicial de $6 \%$ em um mês, $9,5 \%$ em três meses e de $13 \%$ em seis meses ${ }^{96}$.

Contudo a BAE somente tem eficácia associado a atividades físicas e mudanças alimentares. Esta técnica já é bastante utilizada em procedimentos cardíacos e uterinos para cessar sangramentos nos órgãos. O novo procedimento foi apresentado em abril de 2016 no Encontro Científico Anual de 2016 da Sociedade de Radiologia Intervencionista, no Canadá. Outra novidade é que este procedimento é realizado por radiologistas, o que indica a possível inclusão deste profissional na equipe multidisciplinar em caso de aprovação da técnica ${ }^{96}$.

Outro procedimento que está sendo praticado nos EUA em pessoas que preferem alternativas que não seja a CBM por ser um procedimento definitivo e com risco de morte é o AspireAssist que é um dispositivo aplicado em uma técnica aprovada pela Food and Drug Administration (FDA) que tem causado inúmeras discursões na comunidade médica. Um tubo é implantado no estômago por via endoscópica tendo seu orifício de saída implantado na parede lateral do corpo do paciente que vinte minutos após as refeições poderá adaptar um aparelho que suga o conteúdo gástrico (cerca de $30 \%$ dos alimentos ingeridos). 
As discussões em relação ao novo procedimento têm sido em torno da sensação de "aspecto nojento", de possivelmente incentivar a bulimia, de não reeducação alimentar, exige maior atenção no ato de mastigar para evitar obstrução do tubo. $O$ fabricante se defende alegando que $o$ ato de se alimentar não é interrompido ou restrito, pois o cérebro tem tempo para reconhecer a sensação de saciedade e ajuda pessoas que tem um ciclo alimentar irracional, testes clínicos tem tido resultados positivos com perda ponderal em média de $31,5 \%{ }^{97}$.

O número de cirurgias realizadas tem aumentado a cada ano em todo 0 mundo. Somente nos EUA em 1998 foram realizadas 13.365 cirurgias de redução de estômago, em 2007 subiu para 200 mil. No Brasil em 2014 foram aproximadamente 90 mil cirurgias, isto porque o Brasil tem tentado facilitar o acesso ao procedimento de redução de estômago com o objetivo de emagrecimento e equilíbrio metabólico, somente em 2011 houve um gasto de $\mathrm{R} \$ 488$ milhões por parte do Estado brasileiro para tratamento de doenças correlacionadas com a obesidade ${ }^{94,95,98}$. A Portaria oㅜ 628, de 26 de abril de 2001, aprova o Protocolo de Indicação de Tratamento Cirúrgico da Obesidade Mórbida-Gastroplastia no âmbito do Sistema Único de Saúde (SUS) ${ }^{99}$. O número de cirurgias no Brasil até 2014 estão discriminadas na Tabela 3 a seguir: 
Tabela 3. Número de cirurgias bariátricas entre os anos de 2003 a 2014 no Brasil no Sistema público e Privado.

\begin{tabular}{c|cc}
\hline Ano & $\begin{array}{c}\text { Total de Cirurgias } \\
\text { Realizadas }\end{array}$ & Somente no SUS \\
\hline 2003 & 16.000 & 1.813 \\
\hline 2004 & 18.000 & 2.014 \\
\hline 2005 & 22.000 & De janeiro a abril de \\
& & 2005 mais de \\
& & 1000.000 \\
\hline 2006 & 29.500 & Não informado \\
\hline 2007 & 33.000 & Não informado \\
\hline 2008 & 38.000 & Não informado \\
\hline 2009 & 45.000 & Não informado \\
\hline 2010 & (25\% por videolaparoscopia) & Não informado \\
\hline 2012 & 60.000 & \\
\hline 2013 & (35\% por videolaparoscopia) & Não informado \\
\hline 2014 & A2 mil & Não informado \\
\hline
\end{tabular}

De acordo com os dados da Tabela 3 houve um aumento de 4,5 vezes entre o período de 2003 a 2012 e de aproximadamente 10\% de 2013 a 2014. Especificando que segundo a SBCBM $75 \%$ das cirurgias são realizadas por videolaparoscopia por regulamentação da Agência Nacional de Saúde Suplementar (ANS) em 2012, contudo somente na rede privada. No SUS até poucos anos atrás não se realizava o procedimento pela técnica de cirurgia bariátrica fechada por videolaparoscopia, a rede pública quase não utiliza esse procedimento.

O procedimento realizado por videolaparoscopia é seguro, menos invasiva e a recuperação menos dolorosa e precoce em torno de 10 dias comparando com a laparotomia que exige de 45 a 60 dias de cuidados. Muitos 
planos de saúde não cobrem a CBM por videolaparoscopia. O tempo de espera na fila para a realização da cirurgia bariátrica no SUS oscila entre 2,2 anos até 10 anos, estima-se que $10 \%$ dos candidatos desistem da ideia até o momento da cirurgia, preferindo enfrentar os males à saúde, simplesmente porque não abrem mão do prazer de comer ${ }^{100,101}$.

Sendo que qualquer tratamento para controle da obesidade adotado deve ter acompanhamento permanente e contínuo, pois a obesidade é considerada uma doença crônica. Em menos de 1-3\% de todos os casos de cirurgias podem ocorrer infecção ou morte devido a complicações. Os estudos mostram que a perda de peso pode ser mantida por mais de 15 anos, por isto a cirurgia se torna uma ferramenta eficaz no emagrecimento ${ }^{102,103,104}$.

A CBM tenta resgatar o conceito da OMS sobre saúde, propõe a reestabelecer os três fatores (o bem-estar físico, social e mental) de forma a modificar o físico por meio do emagrecimento e melhorias de doenças correlacionadas, além de permitir a inclusão social, eliminando os estigmas e discriminações, além de restaurar o equilíbrio emocional.

\subsubsection{Legislação brasileira sobre CBM}

Os primeiros especialistas neste procedimento sofreram preconceitos por colegas de profissão e também por pacientes, a cirurgia era vista como um procedimento mutilador, pois consistia em alterar órgãos saudáveis. Por isto houve a necessidade de divulgação, isto é, tornar público o assunto de forma a esclarecer as dúvidas e mostrar que se tratava de um procedimento com propósitos e princípios sérios no tratamento da obesidade mórbida. Alguns procedimentos ainda estão sendo acompanhados por meio de estudos em andamento e avaliados pela comunidade científica mundial para determinar as melhores técnicas a serem adotadas ${ }^{105}$.

A legislação sobre cirurgia bariátrica no Brasil ainda está em construção, devido ser um procedimento novo e por existirem várias técnicas já em prática e outras em fase de pesquisa, além de estudos que permitem monitorar pacientes pós-cirurgia com objetivos de avaliar riscos e benefícios em longo prazo. Diante disto, uma nova legislação com o objetivo de atualização surge a 
cada avanço da ciência e também para proteção do indivíduo obeso e gastroplastizado. O procedimento é amplamente aceito pelos órgãos reguladores nacionais e internacionais como um método seguro e eficiente para a redução do excesso de peso em pacientes com obesidade mórbida. $O$ MS, a ANS e o CFM são os responsáveis por regular o procedimento no país. A seguir serão citadas algumas legislações nesta área.

A CBM encontra-se inserida na tabela de procedimentos do SUS desde 1999, quando foi criada a Rede de Atendimento ao Paciente Portador de Obesidade Mórbida, por meio da Portaria ํo 196, de 29 de fevereiro de 2000 que criou os Centros Nacionais de Referência para Cirurgia Bariátrica. Até 2001 já eram 22 centros cadastrados. Em 2005 já existiam 52 hospitais cadastrados. Todos os procedimentos e estratégias para o procedimento de cirurgia bariátrica é custeado pelo Fundo de Ações Estratégicas e Compensação (FAEC). Somente em 2000 o SUS começou a oferecer o procedimento na rede pública de saúde ${ }^{106,107}$.

A Portaria $n^{\circ}$ 628, de 26 de abril de $2001^{108}$, aprovou o Protocolo de Indicação de Tratamento Cirúrgico da Obesidade Mórbida (Gastroplastia) no âmbito do Sistema Único de Saúde. A Portaria no 1.569/GM, de 28 de junho de $2007^{109}$, instituiu as diretrizes para a atenção à saúde, com vistas à prevenção da obesidade e assistência ao portador de obesidade. A Portaria no 1.570/GM, de 28 de junho de $2007^{110}$, determinou a operacionalização da assistência ao portador de obesidade grave.

Outra Portaria de $n^{\circ}$ 492, de $2007^{111}$ trouxe a definição e descreveu como deve funcionar as Unidades de Assistência de Alta Complexidade ao Paciente Portador de Obesidade Grave, informa principalmente o protocolo a ser seguido em relação ao candidato para cirurgia bariátrica e o incremento de $100 \%$ no valor pago em cinco exames ambulatoriais pré-operatórios necessários. Como a Portaria o 492, também habilita novos serviços de assistência de Alta Complexidade ao Indivíduo de Obesidade, os gestores locais ficaram responsáveis por organizar e implantar em sua região a Linha de Cuidado do Sobrepeso e Obesidade. Nesta proposição, os níveis de atenção 
(básica, média e alta) devem estar organizados para a assistência ao paciente obeso.

Em 2012 o MS decidiu reformular as normas que definiam a cirurgia bariátrica no SUS a partir da Portaria ํㅡ 425, de 19 de março de $2013^{112}$ que estabelece o regulamento técnico, as normas e os critérios para o Serviço de Assistência de Alta Complexidade ao Indivíduo com Obesidade. Para o MS a nova legislação não deve ser usada como objetivo primordial para emagrecimento, as políticas de saúde devem ser elaboradas com o intuito de combater a obesidade desde a infância para evitar o tratamento cirúrgico. Deve-se fortalecer as ações primárias incentivando as mudanças dos hábitos alimentares e a prática de exercício regular.

Além do MS, a Sociedade Brasileira da Cirurgia Bariátrica (SBCB) criada em 1999 pelos cirurgiões pioneiros também tem sido atuante em exigir atualização da legislação e observar a ética aplicada no processo de CBM. Hoje não somente médicos são associados, mas outros profissionais de várias especialidades fazem parte, devido à necessidade de troca de conhecimento $\mathrm{e}$ atualização profissional, auxiliar na elaboração de protocolos e fazer parte da equipe multidisciplinar ${ }^{113}$. Então em 2003 a SBCBM defendeu a criação da Comissão das Especialidades Associadas (COESAS) que permite a participação de outros profissionais no tratamento e a criação das equipes multiprofissionais nas cirurgias bariátricas ${ }^{113}$.

Em julho de 2005 o CFM por meio de Resolução de ํㅡ 1.766/05 $5^{114}$ fortaleceu ainda mais a SBCB quando publicou a determinação de que todo cirurgião bariátrico deveria ter uma equipe capacitada para assistir os pacientes em todo o processo pré, trans e pós-operatórios. A composição da equipe deveria ser: cirurgião com formação específica, endocrinologista, nutricionista, psiquiatra ou psicólogo, anestesiologista, fisioterapeuta e que toda a equipe do hospital deveria ser capacitada para atender a população atendida e os efeitos dos procedimentos cirúrgicos. Daí surge à exigência da equipe multidisciplinar no tratamento de CBM.

No ano seguinte, em 2006, no VIII Congresso Brasileiro da SBCBM foi aprovado e protocolado o Consenso Brasileiro Multissocietário em Cirurgia da 
Obesidade que determina a presença da "equipe de profissionais habilitados ou com conhecimentos suficientes para o atendimento do paciente obeso mórbido em programas de cirurgias bariátricas". Em fevereiro de 2010, o CFM por meio de Resolução no $1.942 / 10^{9}$ (Anexo I) alterou a Resolução de no $1.766 / 05^{114}$ de maneira a atualizar a legislação diante dos avanços na prática do procedimento. O CFM trabalha em conformidade com a legislação brasileira seguindo as normas e regulamentos mais atuais sobre o tema.

Em fevereiro de 2011 o CFM promoveu um seminário com pesquisadores, especialistas, representantes dos conselhos de medicina e sociedade médicas e do Comissão Nacional de Ética em Pesquisa (CONEP) para discutir as novas técnicas que estão em fase de observação e as regras para que um procedimento cirúrgico nesta área seja aceito pela entidade. $O$ CFM tem a preocupação de que a ciência e as novas técnicas sejam desenvolvidas com segurança de forma a proteger o paciente em sua vulnerabilidade, por isto para que um novo procedimento seja reconhecido no Brasil, deve passar por uma avaliação da Câmara Técnica de Cirurgia Bariátrica e Síndrome Metabólica do CFM ${ }^{105}$.

Um estudo publicado no periódico The Lancet, em novembro de 2015, foi de grande importância para reformulações nos protocolos da CBM no Brasil e no mundo porque mostrava a efetividade do procedimento em longo prazo acarretando impacto positivo na saúde e também financeiro para o paciente e para o sistema de saúde. Pessoas portadoras de diabetes tipo 2 que foram submetidas à CBM tiveram redução nos gastos com medicamentos e com atendimentos médicos em $30 \%$. Este estudo sinalizou que as diretrizes sobre CBM deveriam ser modificadas para beneficiar pacientes com IMC abaixo de $40 \mathrm{~kg} / \mathrm{m}^{2}$, mas que sofrem por diabetes e que podem ser beneficiados com 0 procedimento. A conclusão do estudo é que há redução com gastos pessoais e consequentemente do Estado em relação a estes pacientes, e ainda há uma orientação de que os pacientes diagnosticados com diabetes tipo 2 até um ano devem ser priorizados na indicação do procedimento ${ }^{115,116}$.

Diante deste estudo, entre outros, o CFM divulgou uma correção da Resolução 1.942/10 em 14 de Janeiro de $2016^{9}$ alterando algumas regras. A 
nova resolução CFM no $2.131 / 2015^{117}$ (Anexo II) manteve o IMC mínimo de 40 $\mathrm{kg} / \mathrm{m}^{2}$, contudo ampliou a lista de exceções, incluindo outras doenças consideradas associadas à obesidade, que podem ser motivo de indicação para a CBM em pacientes com IMC maior que $35 \mathrm{~kg} / \mathrm{m}^{2}$.

Uma lista com 21 doenças: diabetes, apneia do sono, hipertensão arterial, depressão, disfunção erétil, hérnias discais, asma grave não controlada, ovários policísticos, dislipidemia, infarto do miocárdio, insuficiência cardíaca congestiva, doenças cardiovasculares incluindo doenças coronarianas, acidente vascular cerebral, hipertensão e fibrilação atrial, cardiomiopatia dilatada, cor pulmonale, síndrome de hipoventilação, osteoartroses, refluxo gastroesofagiano com indicação cirúrgica, colecistopatia calculosa, pancreatites agudas de repetição, esteatose hepática, incontinência urinária de esforço na mulher, infertilidade masculina e feminina, veias varicosas e doenças hemorroidária, hipertensão intracraniana idiopática, estigmatização social e depressão ${ }^{117}$. (Grifo do autor)

A idade foi alterada, jovens entre 16 e 18 anos poderão ser submetidos ao procedimento de CBM em caso de risco-benefício desde que sejam acompanhados por pediatra e apresentem consolidação das cartilagens das epífises de crescimento dos punhos. A exigência é que o pediatra faça parte da equipe multidisciplinar devido à realização da CBM em crianças e adolescentes. A CBM realizada em crianças será em caráter experimental e seguindo protocolos da CONEP, e pacientes acima de 65 anos deverão ser avaliados as condições clínicas e risco-benefício. A resolução considerou como proscrita a cirurgia de derivação jejunoileal exclusiva devido às complicações decorrentes da grande quantidade de intestino desfuncionalizado. Novas técnicas cirúrgicas para serem praticadas devem ser aprovadas pela Comissão de Novos Procedimentos do CFM, somente devem ser indicadas as quatro modalidades aprovadas pelo CFM, exceto as experimentais aprovadas pelo CONEP ${ }^{117}$.

Houve mudanças também em relação à indicação da CBM em pacientes com alterações psiquiátricas. A resolução anterior orientava a não indicação para pacientes com diagnóstico de quadros psicóticos ou com demências 
graves ou moderadas, com a nova resolução a orientação é a precaução para indicação da CBM para ausência de transtorno de humor grave, de quadros psicóticos em atividade ou de quadros demenciais ${ }^{117}$. Estas mudanças são de grande importância para as pessoas que sofrem de obesidade e doenças associadas, além das que possuem doenças psiquiátricas que não são contraindicadas para 0 procedimento. $O$ texto da nova resolução foi aperfeiçoado de forma a facilitar a leitura dos especialistas e não especialistas, descrevendo as diferentes técnicas, suas vantagens e desvantagens e as exceções.

O Brasil precisa se adequar as novas tecnologias em saúde, pois a população a cada ano está mais obesa e a demanda nos serviços de saúde cada dia aumentando, assim como os gastos em decorrência das comorbidades. Mesmo com a ampliação das indicações da CBM, o controle e monitoramento pelos órgãos competentes são imprescindíveis, pois com 0 advento do novo procedimento criado para perda de peso e para prevenção e controle de doenças correlacionadas com a obesidade, a sociedade equivocada tem tratado o procedimento como algo simples, corriqueiro, com finalidade exclusiva de emagrecimento, um modo rápido de emagrecimento sem necessidade de praticar exercícios físicos e dietas ${ }^{118}$. Ao contrário do que se pensa, o procedimento é complexo e envolve riscos, somente deve ser realizado como último recurso, após as tentativas convencionais de emagrecimento não apresentar resultados satisfatórios.

As normas e requisitos, assim bem como indicações e contraindicações devem ser respeitados e analisados como idade, riscos envolvidos, IMC, presença ou predisposição de comorbidades, tempo da obesidade estável há pelo menos cinco anos, realizado tratamentos convencionais por pelo menos dois anos, conforme Protocolo para Cirurgia Bariátrica (Anexo III). O paciente deve ser esclarecido de todos os benefícios e riscos, bem como ter consciência que se trata de uma cirurgia de grande porte e definitiva. Antes do procedimento o paciente deve obrigatoriamente assinar um termo de consentimento, a família também deve ser orientada para as mudanças de comportamento e hábitos alimentares. Para a realização do procedimento é 
necessário um acompanhamento do paciente no mínimo por dois anos envolvendo o pré-operatório (consultas, palestras, avaliações e exames) por isto a CBM não é considerada uma cirurgia de urgência ou emergência, sendo assim eletiva ${ }^{119,120,121}$.

Mesmo sendo orientada a precaução nas indicações da CBM em pessoas com alguma doença psiquiátrica, é fundamental o uso da ética e bom senso do profissional responsável por indicar. Pois, por mais que muitas doenças psiquiátricas sejam conhecidas e controladas, não existe um consenso na literatura sobre contraindicações da CBM em relação a doenças psiquiátricas como quadros depressivos, bipolaridade e psicose, porém os profissionais devem analisar cada caso, psicoses graves, esquizofrenia e depressão não tratadas estão excluídas totalmente por serem transtornos psiquiátricos incompatíveis com a realização do procedimento ${ }^{119,120}$.

A cirurgia não deve ser realizada contra a vontade do paciente, e quando o paciente for considerado incapaz mentalmente os responsáveis legais podem autorizar. O paciente alcoolista em sua maioria não apresenta um bom prognóstico pós-cirurgia, a evolução não costuma ser satisfatória e há aumento do risco de morte. Cirurgias abdominais e procedimentos bariátricos anteriores não são contraindicações. Pacientes com quadro clínico instável deve tratar primeiro as complicações para minimizar os riscos cirúrgicos ${ }^{119,120}$.

A CBM é considerada um procedimento seguro devido à evolução das técnicas, contudo os riscos ainda estão presentes, mesmo que em menor incidência, a taxa média de infecção é de 0,5\%; riscos cardíacos e pulmonares que ocorrem principalmente em pacientes que já possuem co-morbidades, a taxa média é de 3-5\% e a mortalidade pode chegar a 0,1\%. A média de reoperação pode chegar a $2 \%$ devido a complicações ${ }^{122,123}$. Os riscos no período pós-operatório podem ocorrer, caso existam processos de adoecimento em evolução como obstrução das coronárias, risco de infarto, lesões osteoarticulares, principalmente em joelhos, hemorragias, fístulas, anemia, estenose gastroenteroanastomose, úlcera, obstrução intestinal, distúrbios neurológicos e neuropatias periféricas, entre outros. Outro problema gravíssimo 
é o paciente parar o tratamento após atingir o peso ideal, esquecendo que 0 tratamento é por toda vida para evitar problemas futuros ${ }^{86,122,123,124,125,126}$.

O período pós-operatório imediato é considerado por muitos pacientes como o mais difícil, depois o desconforto na adaptação à nova dieta e a ansiedade pelos objetivos a serem alcançados que exigem paciência e disciplina. O trabalho do psicólogo é muito importante neste período, auxiliando o paciente a aceitar e compreender a nova vida, buscando um equilíbrio emocional e detectar qualquer alteração psicológica ${ }^{127,128}$.

Em relação a aceitação do novo corpo, os que foram sempre obesos desde a infância necessitam de maior atenção em relação às mudanças físicas do que os que se tornaram obesos e que um dia foram magros. A avalição psiquiátrica é para determinar um perfil psicológico e detectar alterações que impedem a realização do procedimento. $O$ acompanhamento destes profissionais vai ajudar o paciente a aceitar a nova imagem corporal e a inclusão social. Também haverá avaliação do endocrinologista, cardiologista e pneumologista $^{127,128}$.

A avaliação da perda de peso deve ser esclarecida ao paciente, pois 0 que se espera do procedimento é que se chegue ao peso ideal, porém o paciente pode perder mais e alcançar um peso abaixo do ideal que se aproxima a uma perda de 50-60\%. A perda de peso no primeiro e segundo ano são mais significantes, após este período a tendência é manter o peso ideal, contudo em alguns casos pode ocorrer um aumento de $5-7 \mathrm{~kg}$. Toda a equipe multidisciplinar deve ter experiência na área de obesidade para planejar, executar e avaliar os hábitos, comportamentos, aconselhar, educar e estimular a mudança de hábitos em longo prazo, sendo com maior ênfase nos primeiros meses ${ }^{129-132}$.

O paciente que será submetido ao procedimento deve ter sua condição clínica estável. Mesmo quando algumas doenças estejam instaladas, como hipertensão arterial, diabetes, devem estar controladas para evitar complicações no ato cirúrgico e no pós-operatório. A estrutura hospitalar deve ser adequado para a realização do procedimento e que atenda as 
necessidades dos portadores de obesidade mórbida. A equipe médica deve conter no mínimo três cirurgiões, dois anestesistas e um instrumentador ${ }^{112,133}$.

O histórico alimentar e presença de distúrbios nutricionais devem ser registrados e corrigidos por meio de suplementação. O nutricionista também é responsável pelas orientações em relação aos novos hábitos alimentares e pelo acompanhamento do tratamento, monitorando e corrigindo deficiências nutricionais, indicando a ingestão de pré e probióticos para melhor neurotransmissão (a maior concentração de serotonina - neurotransmissor do bem-estar - é encontrada no intestino $90 \%$ e não no cérebro), o intestino também produz $80 \%$ do potencial de imunidade do corpo humano e parte do hormônio do crescimento. A ingesta de minerais como cálcio e magnésio estimulam a produção de triptofano (aminoácido precursor da serotonina) Então fica claro que nutrindo a flora intestinal com pré e probióticos, além de minerais o organismo hospedeiro terá benefícios ${ }^{129,131,134}$.

O controle de peso antes da cirurgia deve ser monitorado, pois muitos pacientes em busca do procedimento como um milagre para emagrecer, se arriscam induzindo voluntariamente $o$ aumento de peso por ingesta de grandes quantidades de alimentos para alcançar o IMC igual ou acima de $40 \mathrm{~kg} / \mathrm{m}^{2}$, conduta condenada pelos profissionais de saúde por colocar em risco a própria vida, sobrecarregando os sistemas do organismo, podendo levar a morte ou outras doenças como Acidente Vascular Encefálico (AVE), Infarto, problemas hepáticos e renais ${ }^{135}$.

Outro fator nutricional importante é que muitos pacientes pensam que após alcançar o peso ideal poderão ingerir a quantidade de alimentos que quiser, pois não irá engordar novamente. Caso não haja mudança de hábitos alimentares e estilo de vida, e diminuição da ingesta de alimentos calóricos, pode ocorrer o sobrepeso até chegar novamente à obesidade ${ }^{134,136}$. Os exercícios físicos devem ser realizados após 20-45 dias dependendo do procedimento adotado.

As consultas e avaliações devem ser realizadas semanalmente nos primeiros dois meses, mensalmente no primeiro ano e bimestral no segundo ano, depois a cada seis meses até o quinto ano e anualmente até o décimo 
ano. As dermolipectomias e lipoaspirações somente deverão ser realizadas após avaliação do cirurgião plástico e estabilidade do peso, os requisitos e avaliação para a cirurgia plástica são: elasticidade da pele, idade e fatores de risco ${ }^{113}$.

\subsubsection{Aspectos positivos da CBM}

A CBM tem por finalidade minimizar os danos causados pela obesidade mórbida na vida do indivíduo. Os benefícios do procedimento são reais em relação ao aumento de sobrevida e na melhora da qualidade de vida quando realizada dentro dos padrões adotados internacionalmente e acompanhada durante todo o processo por uma equipe multiprofissional ${ }^{41}$. O emagrecer, na maioria dos casos, favorece o aumento da autoestima do paciente e permite que este consiga lidar melhor com os fatores estressores sociais que antes poderiam gerar ansiedade, insatisfação e, consequentemente, alimentação inadequada ${ }^{135}$.

Com a perda de peso os movimentos corporais se ampliam, a sobrecarrega dos sistemas musculoesquelético que causavam dores e deformidades, é amenizada, os problemas dermatológicos devido acúmulo de fungos nas dobras por excesso de pele e dificuldade de higiene nestes locais, além das doenças varicosas com presença de úlceras e erisipela são minimizadas ou curadas ${ }^{133,137,138}$.

Por isto a dermolipectomia é necessária para a prevenção de doenças e para definição de contorno corporal. A Portaria no 545, de 18 de março de $2002^{139}$, inclui na tabela de procedimentos dos SUS a Cirurgia Plástica Corretiva Pós-Gastroplastia: Dermolipectomia abdominal, crural e braquial, torsoplastia e mamoplastia somente podendo ser efetuadas mediante indicação pelo serviço que realizou o procedimento, em unidades hospitalares habilitadas e por cirurgiões plásticos com título de especialista reconhecido pela Sociedade Brasileira de Cirurgia Plástica ou Certificado de Residência Médica em Cirurgia Plástica. O SUS também oferece acompanhamento nutricional e distribuição gratuita de compostos vitamínicos para suplementação, sendo que 
o indivíduo fará uso de suplementos nutricionais adequados para a manutenção da saúde por toda sua vida ${ }^{140}$.

A CBM não resolve todos os problemas de saúde, mas corrige os que de imediato colocam em risco a vida, como por exemplo, há melhora positiva nos sistemas cardiovascular, respiratório, articular, endócrinos, melhora do nível glicêmico, dos níveis pressóricos, além da restauração do sono, disposição para atividades físicas e o reestabelecimento de um metabolismo considerado normal. A função urinária é normalizada, pois, muitos obesos sofrem de incontinência urinária pelo aumento da pressão intra-abdominal que comprime a bexiga. O problema de disfunção erétil presente em muitos homens obesos é revertido em sua maioria ${ }^{133,138,141}$.

O resgate da autoestima perdida e do ânimo para viver, estimulam a libido, propiciam a busca por novos relacionamentos, amizades e lazer, e algo fundamental é a reorganização familiar e laborativa devido a inclusão social. 0 indivíduo passa a conhecer melhor o corpo e seus limites, buscando e incentivando a promoção da saúde e aumento da qualidade de vida ${ }^{113,142-144}$.

O benefício também se reflete na redução dos gastos públicos ${ }^{83}$. A SBCBM e o Ministério da Saúde afirmam que existem milhões de obesos no Brasil com IMC acima de $40 \mathrm{~kg} / \mathrm{m}^{2}$, são cinco mil casos novos por mês. $O$ tratamento com as doenças decorrentes da obesidade custam ao SUS seis vezes mais que o procedimento cirúrgico devido às várias complicações e gastos com internações, medicamentos e consultas. O Brasil é considerado o segundo centro mundial em cirurgia bariátrica perdendo apenas para os $\mathrm{EUA}^{113}$.

O preço médio de uma cirurgia pelo método tradicional custa entre $R \$$ 10 e $R \$ 15$ mil reais, já a por videolaparoscopia custa entre $R \$ 15$ e 25 mil reais, contudo a por videolaporoscopia é a mais indicada quando se observa o custo-benefício, pois por ser menos invasiva, o tempo cirúrgico é menor, menos riscos de complicações, o paciente tem uma recuperação mais rápida, o custo inicial é compensado em até seis meses pós-cirurgia ${ }^{113}$. Contudo a ânsia de emagrecer faz com que o paciente não perceba a profundidade e complexidade do procedimento, deixando os temas complicações e malefícios 
quase que despercebidos diante da "promessa" de mudança de vida e uma nova imagem refletida no espelho ${ }^{5}$.

\subsubsection{Aspectos negativos da CBM}

A conscientização sobre o método a ser adotado, bem como 0 acompanhamento psicológico, devem reforçar ou não a necessidade da cirurgia, evitando distorções por parte de pessoas que não estão nas faixas correspondentes à obesidade mórbida. Durante o período de pós-operatório e ao longo da vida do gastroplastizado podem surgir sensações de mutilação, depressão e arrependimento.

A CBM seja de restrição ou disabsorção reduz o peso e elimina algumas comorbidades, porém, existem efeitos maléficos decorrentes do procedimento que vão se apresentando em curto ou em longo prazo. As avitaminoses sempre estarão presentes, deficiência de ferro, cálcio, magnésio, os folatos, zinco, vitaminas dos complexos A, B, C, D, E, deficiência de proteínas e ácidos graxos essenciais e outros nutrientes são inevitáveis em mais de $50 \%$ dos gastroplastizados $^{145}$.

As alterações no metabolismo do cálcio, fósforo e vitamina $D$ se refletem na perda da massa óssea, reduz a calcemia, podendo aumentar o risco de aparecimento de doenças ósseas como a osteoporose, oesteopenia, osteomalácia, além de risco de fraturas. Elevação do paratormônio devido à diminuição da absorção intestinal de cálcio. A perda da massa óssea aparece nos primeiros meses pós-cirurgia ${ }^{145}$.

Os níveis séricos dos micronutrientes devem ser acompanhados no período do pós-operatório e suplementados, por exemplo, a Cobalamina (Vitamina B12) está envolvida na síntese de Ácido Desoxirribonucleico (DNA) das células vermelhas, sua ausência acarreta anemia megaloblástica por baixa produção de células e transporte de oxigênio prejudicado. Também está envolvida na produção da bainha de mielina. As deficiências clínicas da diminuição da vitamina B12 ocorrem entre o $1^{\circ}$ e 0 9ํㅜ ano pós-operatório, provocando fadiga, letargia, fraqueza, perda de memória, problemas neurológicos e psiquiátricos ${ }^{146}$. 
A deficiência de vitamina B12 se não corrigida acarreta a anemia macrocítica, é a única vitamina que contém traços de cobalto, importante para o bom funcionamento da medula óssea, do sistema nervoso e gastrointestinal, sua carência acarreta anemias e retardo no crescimento. A cobalamina é produzida no intestino de animais, não pode ser adquirida pelo consumo de vegetais, daí a necessidade de consumo de produtos de origem animal, principalmente vísceras ${ }^{146}$.

Os hábitos alimentares dos gastroplatizados mudam drasticamente. 0 comer e o beber em pequenas quantidades passam a ser prática de paciência, mastigar vagarosamente os alimentos, alguns alimentos devem ser retirados da dieta ou consumidos de forma restrita, para evitar a Síndrome de Dumping ${ }^{2}$ e Efeito Platô ${ }^{35,131}$.

São várias as consequências no organismo devido a ausência de nutrientes como transtornos no sistema nervoso central, neuropatia periférica, fadiga mental, dificuldade no aprendizado e concentração, alopecia, unhas e cabelos quebradiços, dermatites, textura e coloração de pele alterada, ciclo menstrual irregular, anemias, perda de peso em excesso, infecções recorrentes, comprometimento do sistema imunológico, avitaminoses, hipogonadismo, má cicatrização, hiperlipidemia, hipercoagulação, metabolismo anormal de eicosanoides, epífise aberta, baixa estatura, nictalopia, fotofobia, glossite, beribéri, hepatoesplenomegalia, problemas na gestação, Encefalopatia de Wernicke (WE) pela deficiência de tiamina, entre outros ${ }^{147-150}$.

Estas deficiências causadas por diminuição da ingesta de alimentos, má absorção pelo organismo principalmente de carne vermelha, suplementação em quantidade ineficaz, ausência de reserva corporal, excesso de vômitos e episódios de diarreias vão se agravando ao longo do tempo caso não sejam corrigidas. Os suplementos podem e devem ser adotados em quantidades balanceadas e prescritas por médicos, além de acompanhamento nutricional $^{150}$.

\footnotetext{
${ }^{2}$ Complicação comum em gastroplastizados - passagem rápida do conteúdo gástrico para o intestino. De efeito precoce ou tardio após ingesta de alimentos ricos em carboidratos. Pode causar sonolência, fraqueza, náuseas, cólicas intestinais, desmaios e diarreia.

${ }^{3}$ É a aparente estabilidade do peso corporal devido a adaptação do organismo à restrição alimentar. Porém o corpo após um período de tempo reiniciará o ciclo de emagrecimento.
} 
A compulsão alimentar é outro fator de difícil tratamento e adaptação ao procedimento de redução do estômago devido à cirurgia reduzir apenas a estrutura física, não eliminando a sensação de fome. Porém a vontade de se alimentar não tem origem apenas hormonal e sim psicológica como ocorre em episódios de ansiedade, depressão, medo e angústia. Alguns estudos epidemiológicos mostram que a compulsão alimentar está presente em 15\% a $50 \%$ dos pacientes obesos, principalmente mulheres ${ }^{133,147}$.

No Brasil a prevalência de compulsão alimentar entre os que realizaram a gastroplastia é de $27 \%$ a $47 \%$, isto significa que pacientes portadores de compulsão alimentar têm maior probabilidade de recaídas levando ao ganho de peso e reaparecimento de doenças associadas. Algumas pessoas substituem a compulsão alimentar por outros vícios como bebidas alcoólicas, drogas ilícitas, jogos, sexo e apresentam também transtornos de personalidade e insatisfação com a imagem corporal quando comparados com obesos-controle. As estatísticas mostram que muitos pacientes gastroplastizados se tornaram alcoolistas e se arrependeram de terem se submetido ao procedimento ${ }^{133,147}$.

A palavra restrição causa no paciente uma aflição, um comportamento inseguro e dificuldade de adaptação, por isto o acompanhamento psicológico é fundamental para lidar com a instabilidade emocional que se instala nos primeiros meses de tratamento. O ritual da alimentação e a fome estão intimamente ligados aos estímulos internos e externos, sendo algo muito além da necessidade de nutrir o corpo. Muitos pacientes relatam que comem independentemente de estarem ou não com fome, o que reforça a ajuda profissional para equilibrar o emocional ${ }^{151-153}$.

Ainda são escassas as pesquisas e trabalhos publicados sobre as consequências da CBM em longo prazo, principalmente sobre os malefícios. Alguns estudos mostram a redução da mortalidade dos sujeitos que se submeteram à cirurgia chegando até $40 \%$ sendo causas clínicas ou não. Contudo a mortalidade por causas não clínicas ainda preocupa os pesquisadores, pois as mortes por acidentes e suicídio têm chegado a $58 \%$ dos gastroplastizados principalmente no primeiro ano. A principal causa de morte decorrente da CBM é a embolia pulmonar que chega a $50 \%$ dos $\operatorname{casos}^{154}$. 
Assim sendo, Adams et al ${ }^{155}$ considera que as causas de morte por suicídio em pessoas que reduziram o estômago seria por problemas psiquiátricos preexistentes, por isto destaca a importância da avaliação psicológica para detectar risco de suicídio.

Existe 0 aumento da probabilidade de dependência alcoólica, tabaco e drogas e o alto índice de suicídios em pacientes gastroplastizados. O assunto é de extrema importância e se torna um tema a ser considerado neste estudo como um fator maléfico decorrente do procedimento, trata-se do "princípio da substituição de sintomas" onde a compulsão alimentar é substituída por outro elemento compensador, tornando-se em muitos casos um vício. Este é um dos motivos que despertaram para este estudo, inserindo a bioética por meio da DUBDH e seu princípio do "Benefício e Dano".

As emergências por comportamentos por automutilação, ideias suicidas e tentativas de suicídio são frequentes em até $58 \%$ pacientes que realizaram CBM, principalmente no primeiro ano. Um estudo de coorte realizado em Toronto pelo Instituto de Investigação Sunnybrook, entre 2006 e 2011, e publicado em 2015 teve uma amostra de 8.815 doentes, destes 7.176 eram mulheres acima de 35 anos, foram submetidos ao Bypass Gástrico. Durante seis anos estas pessoas foram acompanhas, três anos antes do procedimento e três anos após o procedimento, sendo que 111 destes pacientes apresentaram 158 emergências por automutilação durante o estudo, a (overdose) intoxicação exógena intencional por medicamentos foi o mecanismo mais comum na tentativa de autoextermínio, outros, como a ingesta excessiva de álcool e de outros produtos químicos tóxicos foram relatados, além de traumas físicos ${ }^{156}$.

Embora no início da pesquisa os pesquisadores soubessem que 0 excesso de peso já acarretava problemas psicológicos, pois um total de 147 pacientes foram diagnosticados com transtorno mental durante os cinco anos antes da CBM. Os resultados da pesquisa mostram que a CBM intensificam estes riscos de automutilação em aproximadamente $50 \%$ pós-procedimento, porém não deixa claros os motivos que desencadeiam estes comportamentos. Somente nos EUA em 2014 foram realizadas 200.000 CBM, por isto um 
controle rigoroso deve ser realizado devido os efeitos colaterais decorrentes dos procedimentos que atrapalham os benefícios gerais da CBM ${ }^{156}$. 


\subsection{BIOÉTICA E SAÚDE PÚBLICA}

A bioética criada por Potter ${ }^{157}$ estimulou a integração de várias disciplinas no âmbito da saúde e do meio ambiente, como a medicina, biologia e ecologia, entre outras, dentro de uma filosofia única e tendo como objetivo primordial o estudo da ética da vida humana a partir da relação homem e ambiente. Em seu livro "Bioética: Ponte para o Futuro", afirmou que a bioética é a única solução para que haja diálogo entre a ciência e a ética, sendo assim uma ponte que liga as várias culturas que no passado não se comunicavam.

Contudo, com o passar dos anos, a bioética passou a ser vista e utilizada por outras disciplinas fora do campo saúde e ambiente, sendo interpretada e conceituada por outras ciências aumentando assim o seu campo de ação e ampliando o exercício do conhecimento em prol da proteção dos seres humanos e do meio ambiente em um sentido mais amplo ${ }^{157}$.

Diante da transdisciplinaridade o conceito da bioética passou a ser cognominado de Bioética Global abrangendo as biociências, não sendo uma ciência, mas uma disciplina autônoma e interdisciplinar que visa preservar a dignidade, os valores morais e éticos do comportamento humano e proteger as várias formas de vida de ações danosas provenientes dos avanços das biociências e biotecnologias. Isto pode ser confirmado nas próprias palavras de $\operatorname{Potter}^{157}$ (p. 2): "Eu proponho o termo Bioética como forma de enfatizar os dois componentes mais importantes para se atingir uma nova sabedoria, que é tão desesperadamente necessária: conhecimento biológico e valores humanos".

A bioética se tornou um delta formado por vários canais desaguando em diferentes linhas de estudos, chegando a se pensar não apenas em uma bioética, mas, na existência de "bioéticas", estas seriam desenvolvidas de acordo com as necessidades específicas de cada comunidade, ampliando assim o campo de estudo e criando outros princípios e documentos importantes para o estudo da bioética, além dos já existentes, como: Código de Nüremberg, Declaração Universal dos Direitos Humanos, Declaração de Helsinki, entre outros. 
Com a criação desta nova disciplina, passa a existir uma possibilidade de se construir outros conceitos e novos caminhos, o que leva à interpretação da bioética como um meio e não como um fim. Kottow ${ }^{158}$ (p. 53) define a Bioética como "o conjunto de conceitos, argumentos e normas que valorizam e justificam eticamente os atos humanos que podem ter efeitos irreversíveis sobre os fenômenos vitais". Para Singer ${ }^{159}$ a bioética pode ser denominada de ética aplicada, pois tenta resolver conflitos morais e éticos no âmbito das biociências.

A disciplina bioética introduzida em algumas universidades do mundo trouxe uma linguagem nova, com termos e conceitos ainda poucos conhecidos, despertando a visão dos pesquisadores, educadores, legisladores e cidadãos sobre questionamentos éticos e morais em temas persistentes e emergentes presentes na vida cotidiana, principalmente na área biomédica. A bioética no Brasil, hoje consolidada, surgiu tardiamente tendo como fatores impulsores algumas mudanças ocorridas no campo da política como: o regime militar, a reforma sanitária e a própria criação do SUS. Sofreu, portanto, adaptações e influências destes acontecimentos, o que permitiu sua introdução e base de sustentação conceitual e prática ${ }^{160,161}$.

A bioética brasileira para se consolidar, desconstruiu a bioética principialista de Beauchamp e Childress $^{162}$, ampliando cenários e reflexões relacionados ao campo social, deixando de focar somente em questões de pesquisas científicas e desenvolvimento tecnológico. Surgiram então diversas propostas específicas de enfrentamento das questões sanitárias e sociais no contexto brasileiro.

Entre estas, podem ser especialmente mencionadas: a bioética de proteção, que atribui ao Estado à obrigação de proteger os grupos vulneráveis; assim bem como a bioética da teologia da libertação, que objetiva um diálogo entre os sujeitos sociais permitindo o surgimento de novos caminhos e a busca democrática da cidadania; e a bioética de intervenção, mais direta e enérgica, de fundamento utilitarista e consequencialista, defende que as decisões mais justas são aquelas que beneficiam o maior número de pessoas em um maior espaço de tempo, e que resultam nas melhores consequências, não 
desvinculando o indivíduo do coletivo, pois afirma que o corpo individual (físico) está obrigatoriamente ligado ao corpo social ${ }^{160}$.

As discussões sobre cidadania, acesso à saúde e direitos sociais por meio da Reforma Sanitária foi fundamental para a inserção da bioética na saúde pública. Garrafa ${ }^{163}$ descreve esse processo de interpenetração entre bioética e saúde pública com matizes e de forma enriquecedora em um capítulo de livro "Políticas e Sistema de Saúde no Brasil". Para o autor, a politização da área significou uma reivindicação de cidadania por meio de demandas pela saúde, e nesse processo a bioética fez parte integrante e importante; descreve ainda as diferenças entre uma bioética clássica e principialista e outra bioética enraizada na realidade local e regional. Mas para a latinidade não-central, a bioética também tem uma grande força advinda de sua politização.

É indispensável nesta altura recordar que a criação do SUS favoreceu a construção da cidadania por meio da universalidade e da equidade, proporcionando, assim, o acesso igualitário aos serviços de saúde, tornando a saúde como um bem universal. Neste contexto, a garantia da atenção à saúde, somente é conquistada se a população tiver condições de acessibilidade aos serviços. A saúde pública no contexto brasileiro apresenta princípios com alto teor bioético, pois tem suas origens na moral e na ética por ser um direito legítimo da sociedade conquistado por meio de lutas de classes. A saúde pública sempre foi negligenciada, conforme afirma Berlinguer ${ }^{164}$ (p. 16):

O tema da saúde raramente está presente no debate bioético.
Este privilegia tão-somente as situações extremas como os
nascimentos 'artificiais', os transplantes de órgãos, as
condições de sobrevivência terminal, descuidando-se do fato
de que a saúde e a doença são para todos um campo universal
de experiência, de reflexão, e até de escolhas morais. À saúde
frequentemente é negado o título de nobreza como objeto da
ética e, na melhor das hipóteses, lhe é atribuído apenas o valor
(que para alguns é considerado filosoficamente irrelevante e
intelectualmente plebeu) de "questão social".

Schramm e Castiel ${ }^{165}$ afirmam que os debates bioéticos têm construído uma ampla base de conhecimentos e conceitos oferecendo a possibilidade de 
resolver conflitos de interesses e valores que se apresentam na saúde pública, que englobam responsabilidades dos governos e cidadãos. De acordo com Schramm, Rego e Palácios ${ }^{166}$ quando a bioética se integra à área da saúde a ética profissional não pode ser baseada apenas em regras, normas e códigos, não se reduzindo apenas à ética hipocrática. Esta disciplina agrega valores morais, sejam estes denominados direitos, princípios, virtudes ou cuidados.

Até 2004 o contexto da bioética girava quase que exclusivamente em torno dos quatro princípios explicitados por Beauchamp e Childress ${ }^{161}$ na obra "Principles of Biomedical Ethics", que referenciou a bioética dos seus primórdios e até então: autonomia, beneficência, não maleficência e justiça. Contudo, em 2005, houve uma profunda transformação na bioética mundial, a aprovação da DUBDH, homologada pelos 191 países componentes da Unesco.

A DUBDH além de considerar os quatros princípios mencionados acrescentou vários outros ao contexto da bioética que passaram a fazer parte de seu escopo conceitual e prático. Esta mudança significou a incorporação definitiva à agenda bioética do século 21 , não somente os temas biomédicos e biotecnológicos foram contemplados, mas também as questões sanitárias e sociais. Se até então a bioética se ocupava preferencialmente com temas individuais vinculados à relação profissional-paciente e dos pesquisadores com sujeitos de pesquisa, passou a ter reconhecida uma conotação preferencialmente coletiva, societária, mais politizada, adquirindo uma identidade pública ${ }^{167}$.

As discussões para elaboração e aprovação da DUBDH se basearam em diversos temas em torno dos direitos humanos, da dignidade humana, da preservação da biodiversidade e dos recursos naturais, da não-discriminação e não-estigmatização, da proteção dos vulneráveis, do resgate da cidadania, questões da qualidade de vida humana, alocação de recursos, solidariedade entre os países em relação a minimizar a pobreza e exclusão social, responsabilidade ética e moral dos Estados, industrias e pesquisadores ${ }^{167}$. O paciente passou a ser considerado um indivíduo a ser protegido, não somente da autoridade médica, mas, também, da sociedade e do próprio Estado. Nesse 
sentido, a bioética pode significar um processo de politização da saúde e uma fonte do chamado empoderamento das populações ou grupos.

Seguindo este pensamento de acesso à saúde e promoção da saúde, que são dois grandes problemas enfrentados pelos cidadãos brasileiros enquanto detentores do direito à saúde e também do Estado que tem o dever de ofertar estes serviços de forma integral, equitativa e universal. Destaca-se a importância do estado brasileiro no combate às DCNT, neste caso específico será citada a obesidade mórbida por ser tema diretamente interligado à este estudo.

Segundo o MS a obesidade apresentou índices crescentes de prevalência constantes nos últimos 30 anos $^{168}$. Diante deste cenário o sistema de saúde teve que se organizar para atender esta demanda e preconizar cuidados específicos para este sujeito. Inúmeros tratamentos para a obesidade foram testados, sejam medicamentosos ou não, porém nada permanente, sendo a obesidade reincidente em várias pessoas. Então surge a cirurgia da obesidade como uma forma definitiva de redução de peso e melhora das doenças relacionadas com o quadro de obesidade.

Por ser uma intervenção que utiliza várias técnicas existe a necessidade de um monitoramento por meio de avaliações sobre riscos e danos, e quais os benefícios reais na vida do paciente após o procedimento. Daí a importância da bioética como um caminho capaz de discutir e analisar os impactos deste procedimento na vida das pessoas, da sociedade e do Estado. A DUBDH tem o papel de elemento articulador na composição dos saberes dentro das instituições de ensino e saúde, e na educação profissional, buscando a intersetorialidade e interdisciplinaridade, de forma a orientar na elaboração de diretrizes do cuidado integral e adequado ao cidadão, dando ênfase na proteção e eliminação dos riscos.

Um dos objetivos da DUBDH é o de proteger o indivíduo enquanto objeto de estudo em áreas da medicina, das ciências biológicas em geral e do impacto que as novas tecnologias e procedimentos podem causar sobre 0 organismo humano e se todos os fatores que envolvem este indivíduo estão sendo avaliados e levados em consideração como: a vulnerabilidade seja ela 
social (discriminação e estigmatização), econômica, cultural, religiosa, sexual e ambiental. A DUBDH dá voz aos sujeitos que usufruem e participam das ações da ciência e das novas tecnologias, permitindo assim que os discursos destes, mesmo que por vezes, empobrecidos de conhecimentos científicos sejam levados em consideração no momento das decisões.

O tema discriminação e estigmatização tem destaque nas discussões bioéticas. O Comitê Internacional de Bioética (CIB) deu destaque ao abordar o artigo 11 da DUBDH em 2012/2013 durante a $19^{\circ}$ e $20^{\circ}$ sessões realizadas em Paris e Seul respectivamente, por meio de um relatório elaborado e apresentado pelo CIB sobre não-discriminação e não-estigmatização. Este relatório abre espaço para discussões, esclarecimentos, significados e aplicações do artigo na vida cotidiana no combate a discriminação e estigmatização ${ }^{169}$.

O artigo 11 está interligado com o direito internacional sobre direitos humanos, pode e deve ser aplicado em questões éticas que envolvam a medicina, ciências e biotecnologias e outras tecnologias aplicadas aos seres humanos sendo assim utilizado em várias dimensões sociais, políticas, ambientais e legais que de alguma forma prejudique a dignidade humana, os direitos e as liberdades fundamentais de forma discriminatória. Qualquer ato discriminatório que infringe os direitos e liberdades do ser humano deve ser proibido, nenhuma destas características deve ser motivo de desqualificação ou restrição da pessoa humana como raça, sexo, religião, opinião política, nacionalidade e orientação sexual ${ }^{169}$.

O relatório trata o estigma mais como uma questão social que legal por ser uma marca ou característica do corpo que pode representar motivo de vergonha ou descrédito e isto ser motivo de desrespeito. O Estigma é trabalhado em cima do medo e motivado pela ignorância. Contudo, orienta que o tratamento das práticas discriminatórias e estigmatizantes explícitas que já são conhecidas exigem ação de intervenção imediata no sentido de prevenir e punir, seja de forma legal ou normativa. Os casos em que a discriminação e estigmatização sejam ainda de forma velada devem ser monitoradas, identificadas e inibidas para evitar riscos e investir em promoção da 
conscientização de que a discriminação e estigmatização são motivos da exclusão e violência social ${ }^{169}$.

Este estudo significa por em prática o artigo 11 da DUBDH e as orientações do relatório sobre não-discriminação e não-estigmatização, no sentido de informar, orientar e contribuir para a construção de uma sociedade não-discriminatória e não-estigmatizadora. Os próximos capítulos apresentados neste estudo tem a pretensão de esclarecer, mesmo que de forma simplista, as discussões sobre conceitos de Benefício e Dano, de Não-estigmatização e Não-discriminação abordados na DUBDH, assim bem como expor a visão de alguns bioeticistas sobre os temas obesidade e CBM de forma a ampliar e divulgar o conhecimento e estimular as discussões bioéticas para possíveis soluções para o "meio da vida" ou da "continuidade da vida" e não somente para o início e fim da vida.

\subsubsection{O princípio do "Benefício e Dano"}

Para melhor entendimento e argumentação, se faz necessário, expor algumas discussões sobre Benefício e Dano. Com o avanço das tecnologias em saúde e seu uso principalmente na medicina, alguns costumes, conceitos e pensamentos foram sendo modificados e até mesmos substituídos com 0 intuito de adaptar aos novos acontecimentos. As modificações adotadas corroboram com os princípios fundamentais da Bioética, na tentativa de conciliar teoria à prática. Alguns textos passaram a defender a autonomia do paciente, a justiça social, a abordar temas como a mercantilização da medicina $^{170}$.

Um documento que se destaca é a Carta do Profissionalismo Médico de 2002 redigida e aceita por instituições médicas norte-americanas e europeias que orienta, protege e direciona o profissional médico em suas condutas, está estruturada em três princípios: 1) princípio ao bem-estar do paciente dedicação em servir o paciente; 2) autonomia do paciente - respeitar a decisão do paciente e empoderar os mesmos para que possam tomar decisões e 3) justiça social - trabalhar no sentido de combater a discriminação na saúde em 
relação a qualquer categoria social. Adotados também dez compromissos ou obrigações (competência profissional; sinceridade com os pacientes; sigilo profissional; apropriado relacionamento com os pacientes; qualidade do atendimento; facilidade de acesso aos cuidados médicos; distribuição justa de recursos financeiros alocados à saúde; atualização científica; integridade nos conflitos de interesse; responsabilidade profissional) ${ }^{171}$.

Até mesmo o Juramento de Hipócrates foi ultrapassado pelos novos avanços científicos, passando a representar uma declaração simbólica, porém sem praticidade. Todas estas discussões e mudanças tiveram como objetivo principal a adequação aos princípios éticos, por meio de esforços da comunidade médica, de profissionais não médicos e da sociedade em se combater condutas e políticas que não garantam o benefício do procedimento ao ser humano, reprimindo abusos como os ocorridos no passado, principalmente durante as duas grandes guerras ${ }^{172}$.

A vigilância e controle por meio de documentos importantes como o Código de Nuremberg (1947) e a Declaração de Helsinque (1964) determinaram a melhoria na qualidade de vida da humanidade, servindo como fundamento para elaboração de outras ferramentas que priorizam o bem-estar humano e regulam os interesses da ciência. Também a criação do Conselho de Organizações Internacionais de Ciências Médicas (CIOMS) pela OMS e pela Unesco em 1949 foi importante no sentido de desenvolver as Diretrizes Éticas Internacionais para Pesquisas Biomédicas Envolvendo Seres humanos ${ }^{172}$.

A intenção na criação destes documentos restritivos não era condenar a experimentação científica, de maneira a anular seus benefícios, pois avanços no conhecimento e experiências benéficas trouxeram alívio e bem-estar para a sociedade como: as vacinas, a insulina, antibióticos, anestésicos, pesquisas sobre história natural das doenças, seus diagnósticos e tratamentos. O alerta principal em avanços em pesquisas com seres humanos é que a maioria das pesquisas realizadas são financiadas por empresas particulares com interesses meramente econômicos o que merece vigilância do governo e da sociedade em geral em todas as suas fases ${ }^{172}$. 
Diante disto, a beneficência da medicina paternalista e impositiva, passa a ser vista como "Beneficência Verticalmente Paternalista", isto é, imperialista ${ }^{173}$. Por isto a bioética não deve ser vista como uma barreira para a ciência, mas como uma ferramenta que ensina e exige uma nova postura do médico diante do ser humano ${ }^{174}$. A seguir serão expostos alguns conceitos do que venha a ser o Princípio do Benefício e Dano dentro de uma visão bioética mais ampla. A DUBDH em seu artigo $4^{\circ}$ aborda o tema Benefício e Dano como princípios que devem ser observados e praticados em qualquer procedimento realizado em seres vivos.

A declaração permite a interpretação de que o Princípio do Benefício deve promover o bem do individuo e seus interesses, de maneira a reconhecer o valor moral do outro. O profissional passa a ter a obrigação de avaliar os riscos e benefícios que uma determinada ação terá como consequência. Para tal, o profissional deve ter competência teórica e técnica para praticar determinadas atitudes. Se eximindo do paternalismo, porém agindo de forma a preservar a autonomia e mantendo um bom relacionamento com o paciente ${ }^{175}$.

O fazer o bem é a mesma coisa que beneficiar o outro, sempre avaliando os riscos e evitando causar o mal, mesmo que indiretamente. Assim, o não causar o mal é a mesma coisa que não prejudicar o outro, minimizar os riscos ao ponto de não causar sofrimento ou dano. Isto demonstra que o benefício e o dano estão interligados porque se alguém opta em fazer o bem obrigatoriamente não irá fazer o mal e se alguém opta em não fazer o mal obrigatoriamente irá fazer 0 bem, mesmo que indiretamente ${ }^{174}$. O Relatório Belmont ${ }^{176}$ praticamente contempla as duas expressões como sendo complementares e interdependentes, pois a ação benéfica somente se concluirá quando os danos forem minimizados ou anulados.

As diferentes "bioéticas" assim como as várias facetas do direito trouxeram mudanças sobre as decisões em relação aos aspectos mais íntimos do estado de saúde do ser humano. Sendo assim o princípio da beneficência não deve ser praticado de maneira absoluta pelos profissionais médicos e nãomédicos, pois o seu ponto limítrofe é a autonomia e a dignidade de cada pessoa, isto é, o indivíduo tem o direito de decidir se quer ou não ser 
beneficiado $^{172}$. A obrigação médica não deve ultrapassar a liberdade individual, caso contrário será considerado prática de abuso, o que tornará esta relação fragilizada e deteriorada ${ }^{173,177}$.

Beneficência não deve ser utilizada como sinônimo de outros termos como a solidariedade, bondade. A beneficência em sua tradução filosófica moral por si só se define como ato de beneficiar, ação de fazer o bem a alguém. Deriva do prefixo latino "bene" que quer dizer excelência, muito bom ou bem, que dá origem às palavras benevolência, benefício, beneficência, benfeitor, bem-estar, entre outras e do sufixo "ência" que define uma ação ou resultado da ação. Sendo que existem diferenças entre os significados das palavras: benevolência - desejar o bem ao outro, estar disponível para fazer o bem, e ligada à disposição de agir com bondade; e beneficência - ação de fazer o bem ao outro ${ }^{178-181}$.

Quando a bioética incorpora o princípio da beneficência como uma de suas bases, ela parte do princípio que a beneficência deve ser praticada, justificada e compartilhada, de forma que o profissional de saúde e o paciente decidam quais as ações são beneficentes e quais os limites que devem ser respeitados, preservando assim a autodeterminação do paciente e mantendo mesmo que controlada a autoridade médica. Deixando assim de ser uma decisão unilateral e passando a ser um processo de escolha compartilhado e responsável ${ }^{180-182}$.

O principio da beneficência antes de ser principio é uma obrigação, um dever, porém não é absoluto, pois se limita nas obrigações morais, a sua prática se esbarra em situações ou condições que dependem de condições legais ${ }^{184}$. A beneficência deve ser obrigatória, inespecífica e imparcial, devendo todos se beneficiar. Este princípio deve alcançar todos os indivíduos e não somente os mais próximos como familiares e conhecidos. Muitas vezes o principio da beneficência se confronta com o principio do utilitarismo, o que traz sérios conflitos morais, como impedir que outros sofram diante de limitações econômicas, beneficiar grupos protegidos por leis em detrimentos de outros, como não praticar o mal em situações de perigo ${ }^{183-185}$. 
Em relação à CBM o princípio da beneficência se aplica na melhor forma de agir em relação ao paciente. A medicina se diferencia nas ações benéficas quando tenta impedir consequências maléficas. Então, este procedimento assume um caráter bioético quando praticado como principio da beneficência por possuir características de prestação de beneficio a pessoa com obesidade mórbida, desde que se respeite as regras morais como a autonomia, a dignidade, a liberdade e o respeito.

Contudo a CBM é um procedimento que altera a anatomia e a fisiologia de órgãos saudáveis, causando um pequeno dano controlado ao organismo em que o custo-benefício é considerado maior que as alterações. Como o cérebro não podeser alterado por meio cirúrgico, a melhor opção é alterar os órgãos controlados pelo cérebro por meio de interferência anátomoneurofisiológica. Os danos ou efeitos adversos em consequência da CBM são mínimos quando comparado ao risco de desenvolvimentos de doenças incapacitantes e o risco de morte iminente.

A palavra dano tem origem latina "damnum" que significa mal, ofensa material, física ou moral causada a alguém por outro individuo ${ }^{186,187}$. Somente ocorre o dano propriamente dito caso o individuo afetado se sinta diminuído em sua dignidade, existência ou seja inutilizado ou deteriorado por ação de terceiros, sendo assim considerado um ato lesivo e prejudicial passivo de penalidade diante da legislação ${ }^{186,187}$. Destacando o princípio da nãomaleficência como um princípio do juramento hipocrático, que significa não causar dano ao outro seja por socorro ou por omissão. Então o princípio da não-maleficência requer abstenção da ação e abrange a todos, segundo Beauchamp e Childress ${ }^{162}$ este princípio é uma obrigação que tem por objetivo prevenir danos.

Contudo Gillon ${ }^{188}$ afirma que mesmo a beneficência estando acima da não-maleficência, a medicina se utiliza de, às vezes, causar danos em prol de um benefício maior, e justifica que muitos pacientes permitem a ação danosa em virtude de uma questão de sobrevivência, o que o autor denomina de "Teoria moral do duplo efeito". Exemplos: a amputação de um braço ou perna em consequência de um câncer ou gangrena, um tratamento com 
quimioterápicos combate células cancerígenas, mas também danificam células saudáveis.

$O$ autor ainda afirma que o dano somente deve ser causado e justificado quando realizado para o bem do beneficiado, isto é o paciente. Nunca deverá ser realizado para beneficiar terceiros, exceto em casos específicos de acordo com a legislação como, por exemplo, transplante entre vivos ${ }^{188}$. Isto mostra a fragilidade e não absolutismo do principio da beneficência, pois a sobrevivência do restante do organismo seria a justificativa para a prática de um dano, exemplo disso e a CBM quando altera a anatomia de órgãos saudáveis.

Diante dos argumentos apresentados, pode-se afirmar que a visão de Beauchamp e Childress em tornar os quatros princípios (autonomia, beneficência, não maleficência e justiça) como absolutos para resolver qualquer conflito não condiz com as "bioéticas" existentes, principalmente na América Latina, necessitando assim de outros "caminhos bioéticos" que pode ser a Bioética de Intervenção, por exemplo, (teoria que fornece novas bases do agir moral na ética biomédica) que contempla a prudência como uma ferramenta para intervir em questões que envolvam riscos e danos à saúde humana por meio da introdução de novas biotecnologias ou novos procedimentos na área médica ${ }^{184}$.

A aplicação ética do princípio da prudência também está diretamente relacionada nas decisões adotadas frente aos princípios da beneficência e nãomaleficência. $O$ conceito de prudência segundo Houaiss ${ }^{190}$ é virtude que faz prever e procurar evitar as inconveniências e os perigos; cautela, precaução. Para Hossne ${ }^{191}$ (p.185) a prudência na visão bioética significa "sensatez, moderação, comedimento, cautela, cuidado, precaução, além de previsão, temperança, sabedoria prática, razoabilidade, englobando, ainda, experiência, modéstia e bom senso". A prudência está associada ao discernimento entre o bom e o mau, utiliza-se da justa medida, sem excessos e não se restringe apenas às normas morais, mas se aplica a qualquer ação para evitar conflitos na prática moral ${ }^{192}$. 
Os diálogos bioéticos trazem reflexões aos procedimentos que outrora eram meramente técnicos. O novo contexto de participação ativa dos sujeitos envolvidos no processo modifica principalmente a relação profissional de saúde-paciente. A nova realidade tem sido uma relação participativa, horizontal, em que o paciente deixa de ser um mero objeto, passando a ser um participante, questionando, aceitando e com frequência rejeitando as condutas médicas. O processo de CBM permite a horizontalização da relação médicopaciente porque um depende do outro para que o procedimento aconteça e alcance resultados positivos.

O acesso ao procedimento CBM não somente abrange o princípio da boa-fé por ser um tratamento benéfico que liberta o indivíduo do desassossego e sofrimento causado pela própria enfermidade trazendo qualidade de vida, mas também contempla os direitos à proteção da dignidade da pessoa humana, pois traz a compensação de um dano moral social, inibi a prática da exclusão por meio da estigmatização e discriminação e ressalta o direito à vida já que a obesidade mórbida é circuncidada por outras doenças que associadas acarretam risco de morte.

A Constituição Federal do Brasil de 1988 (CF) não traz a definição do que venha ser dignidade humana, apenas a cita como um fundamento do Estado Democrático de Direito e afirma de forma implícita em todo o documento que todos os direitos fundamentais devem ser baseados e interpretados de forma a preservar a dignidade humana ${ }^{193,194}$. Assim ressalta Sarlet ${ }^{199}$ que a dignidade humana na condição de valor fundamental absorve todos os outros direitos fundamentais, exigindo, reconhecendo e protegendo o indivíduo em todas as dimensões, então a partir do momento em que o sujeito seja privado de seus direitos fundamentais, consequentemente está sendo-lhe negado também o direito à própria dignidade como ser humano.

A DUBDH reforça e complementa o que a CF de 1988 não esclarece de forma absoluta. A DUBDH aborda a dignidade humana de forma distinta como um direito absoluto na prática, assim como os direitos humanos que são fundamentais e positivados, de modo que o resultado de um julgamento passe por um processo de ponderação e que nenhum direito fundamental seja 
sobreposto ou mais importante que o outro, pois são interdependentes em sua essência. Neste caso cabe ao julgador (planos de saúde, médicos e sociedade) ponderar e proteger o direito do sujeito com obesidade mórbida de maneira a preservar e fazer com que prevaleça o seu bem-estar e sua dignidade como um direito absoluto, como aconteceu nos casos concretos de condenar o ato de tortura, escravidão e qualquer tratamento humilhante do ser humano de forma universal.

Considerada um direito natural a dignidade tem sua expressão conotativa, isto é abstrata, ela existe, porém faz parte da consciência humana, representada de diversas formas de acordo com a visão e necessidade de cada indivíduo, é considerado um bem de valor imensurável, intangível e inalienável, não palpável ${ }^{194}$.

A dignidade está associada à liberdade e à igualdade baseando-se no gênero humano, pois é impossível ter dignidade e ser igual quando não se é livre. Porém não basta ser livre para ser digno, para se ter dignidade devem ser assegurados outros direitos, dentre estes a busca por respeito às diversidades. Quando se trata do portador de obesidade mórbida o Estado tem a obrigação de inibir abusos e desrespeito com o corpo do ser humano bem como seus sentimentos. Deve então garantir o direito à integridade, outro princípio defendido pela DUBDH em seu artigo $8^{\circ}$.

O que possibilita o Estado agir de maneira a garantir a integridade física, emocional, moral, mantendo assim o equilíbrio humano e a proteção dos grupos vulneráveis, promovendo a justiça social. A obesidade mórbida com suas inúmeras origens intrínsecas e extrínsecas têm seus históricos de tragédias, violência, tortura, conflitos familiares, castração de sonhos e mortes, tendo como uma das causa o estigma e a discriminação por parte da sociedade. Então, a DUBDH se revela como fonte de reconhecimento e garantia de proteção da dignidade humana, sendo esta associada à liberdade, igualdade, não-discriminação, não-estigmatização e acima de tudo a prática da solidariedade entre as pessoas e Estados no intuito de repressão a qualquer ato discriminatório contra determinados grupos, incluindo assim os obesos mórbidos. 
Como afirmava Kant, o ser humano deve ser considerado como um fim em si mesmo, possuidor de autonomia para traçar seu próprio caminho, não ser trocado como mercadoria, não ser substituído e não ser menosprezado, assim será dotado de dignidade ${ }^{195}$. O portador de obesidade mórbida deve ser considerado uma pessoa com valores, historicidade, facticidade e merecedora de respeito como qualquer outro ser humano, independente das justificativas religiosas, filosóficas e científicas que tentam conceituar o que venha ser dignidade.

Todos estes assuntos faz com que haja uma relação direta entre a bioética e a CBM a partir do momento em que envolve o direito à saúde e o direito a dignidade por serem direitos fundamentais. A dignidade é um direito fundamental, individual e intransferível, e não pode ser objeto de violação. A dignidade não é uma concessão, neste caso não pode ser retirada, ninguém tem o poder de concedê-la, pois ela é inerente ao ser humano, esta associada a existência humana ${ }^{196}$.

Mesmo sendo à dignidade inerente ao ser humano, sua ausência e violação devido à segregação social, tem se tornado demanda jurídica no intuito de resgatá-la por meio da "judicialização", isto é, a busca da prática constitucional, pois é fundamento para a tutela do direito à saúde. A judicialização parte do princípio que à saúde é um direito das pessoas e obrigação do Estado, porém o Estado não somente deve respeitar e proteger este direito como deve também promover os meios de acesso à obtenção da saúde com qualidade.

A judicialização não é a melhor ferramenta para o acesso à saúde, uma vez que o meio legal é a elaboração de políticas públicas que contemplem estes temas, mas na ausência destas, a judicialização tem se mostrado o caminho de resgate da dignidade, principalmente de grupos vulneráveis que em algum momento tem a necessidade de serem reconhecidos como cidadãos, mesmo que em condições sociais desfavoráveis ${ }^{197}$. A obesidade atinge todas as classes sociais e os menos favorecidos têm o direito de ter acesso aos mesmos recursos, neste caso a CBM, partindo dos princípios da igualdade, equidade e universalidade descrita na Lei 8080/90 ${ }^{198}$. 
A busca pela saúde representa alcançar uma melhor qualidade de vida que envolve aspectos relacionados com o estado físico, psicológico, econômico, cultural, religioso e social ${ }^{199}$. Quando se fala em CBM não se deve pensar apenas em perda de peso, mas em manutenção da saúde, da vida e da qualidade de vida, extinção ou melhora das comorbidades associadas ao excesso de peso. Os benefícios do procedimento também deve levar em consideração o resgate da dignidade, melhora da autoestima, à inclusão social, mudanças nas atividades rotineiras como trabalho, estudo, atividade física, atividade sexual, aumento da longevidade e outros. Pois a obesidade mórbida acarreta em muitas pessoas a crise existencial, não querer mais viver devido às dificuldades enfrentadas e a morte é vista como um fator aliviador.

A CBM não deve ser vista como um procedimento "mágico" que resolve todos os problemas, mas sim como um procedimento auxiliador na melhora da saúde, porém implica riscos e consequências como qualquer outro procedimento e os profissionais envolvidos assim como o próprio paciente devem ter consciência de que os benefícios e mudanças na vida pessoal não se restringem apenas à perda de peso, pois a cirurgia traz mudanças drásticas na vida pessoa e social do indivíduo.

\subsubsection{O princípio da "Não-Discriminação e Não-Estigmatização"}

As vítimas da obesidade são discriminadas e consideradas menos capazes de executar tarefas cotidianas, além de constituir motivo de piadas e comentários maldosos. Neste contexto é impossível abordar os temas bioética obesidade e CBM e não destacar a DUBDH e seu artigo 11 que trata da "Não discriminação e Não-Estigmatização".

Para entender o que é Não-estigmatização deve-se entender o que é estigma. Na língua portuguesa a palavra estigmatizar possui alguns sinônimos como: cicatriz, ferrete, lábeu, condenar, rotular negativamente, marcar, mancha, máscara, vestígio, tachar, tatuar, vergonhoso, infame, degradante, acusar, censurar, culpar, entre outros ${ }^{200}$.

A palavra estigma é confundida muitas vezes com outras palavras: estereótipos, racismo, preconceito, intolerância e discriminação. Estereótipo é 
uma visão engessada e generalizada que alguém tem em relação ao outro ou de algum grupo social, se baseando apenas em um mau comportamento de um dos membros deste grupo, como por exemplo: negros, moradores de rua, homossexuais, obesos. Racismo é a crença da superioridade de uma raça sobre a outra ou origem, se baseando em diferenças físicas e de comportamento, como por exemplo: os negros e brancos, os habitantes do norte e nordeste com o sudeste do país. Preconceito é um pensamento ou atitude em relação ao outro antes mesmo de conhecê-lo ou ter tido experiência com este, são ideias preconcebidas e generalizadas, está relacionado com o estereótipo e o racismo, o estigma é uma predisposição para o preconceito 201,202

Intolerância é a não aceitação ou não reconhecimento das diferenças e ideologia do outro, tendo como consequência a perseguição e a rejeição do pluralismo moral e social. Discriminação é o tratamento diferenciado e injusto entre pessoas em razão de não pertencerem ao mesmo grupo, caracterizado por uma violação aos direitos fundamentais, como por exemplo: segregar pessoas por classe social, cultural, econômica, por raça, cor, gênero, condição física, entre outras. A discriminação é um tipo de intolerância ${ }^{201}$.

O preconceito e a discriminação estão interligados, porém podem ser executados separadamente, como por exemplo, uma pessoa pode ser preconceituosa, porém não demonstrar em sua maneira de agir. A presença e execução destas palavras no meio social representam a desigualdade e a exclusão da cidadania, a segregação de grupos que não se reconhecem como iguais pertencentes à mesma origem "seres humanos". Significa que a sociedade não tem capacidade de pensar racionalmente, menosprezando 0 pluralismo social e o multiculturalismo ${ }^{201}$.

Estigmatizar é o ato de descredenciar o indivíduo de sua identidade natural, tachando-o por alguma característica própria que está fora do padrão imposto pela sociedade. O estigma é um sinal natural ou provocado presente no corpo que traz vergonha, distinção e isolamento. Existem estigmas que são controláveis como a obesidade, alguns comportamentos, o uso de drogas, analfabetismo, algumas doenças psiquiátricas; e alguns estigmas que não 
podem ser evitados ou controlados como defeitos congênitos e doenças incuráveis como o câncer, cegueira, algumas doenças de pele, velhice, doenças degenerativas, amputações de membros. A intolerância e preconceito associados geram a estigmatização, a não aceitação do outro com suas diferenças, abrangendo várias categorias como cultura, religiosidade, profissão e o jeito de viver - posturas e comportamentos ${ }^{203,204}$.

Como citado por Goffman (p.11) ${ }^{204}$ os gregos definiam estigma como "sinais corporais, que estão tentando mostrar algo ruim e incomum no status moral de quem os têm”. Em muitas civilizações antigas os indivíduos que por algum motivo não podiam conviver em sociedade eram marcados por um corte ou queimadura para que pudessem ser identificados, como por exemplo, os assassinos e escravos que possuíam um estigma e assim eram desacreditados, sendo impedidos de ter uma vida social, sendo destituídos da cidadania e reduzidos apenas a uma marca ou sinal.

Aqueles que possuíam deformidades físicas ou distúrbios mentais também representavam uma ameaça à sociedade, por possuírem uma característica negativa e ameaçadora aos padrões de normalidade, perdendo assim sua identidade real, o que Goffman"204 define como "identidade deteriorada".

Alguns países ainda praticam o castigo físico como uma ação estigmatizadora como forma de punição por atos cometidos contra a sociedade e em contradição com as leis internas, como por exemplo, em alguns países árabes em que a lei é rigorosa quando se trata de crimes como estupro, roubo, tráfico de drogas, homicídio, e comportamentos reprováveis considerados crimes contra a moralidade pública como adultério, homossexualismo e embriaguez $^{205}$.

As penas variam de acordo com o delito cometido, as mais severas incluem amputação das mãos e pés para quem pratica o roubo sem uso de armas, flagelações em crimes menos graves como embriaguez, e pena de morte em crimes considerados graves como o tráfico de drogas, estupro, bruxos, sodomitas, roubo a mão armada em que são decapitados com um 
único golpe de espada. Todos estes castigos são realizados em praça pública com o objetivo de controlar a ação maléfica, impor limites e manter a ordem social, além de evitar que outros membros da família do criminoso sejam vítimas do ódio da família da vítima. O condenado somente tem a chance de escapar do castigo, em casos de pena de morte, se a família da vítima perdoálo, ficando assim responsável por uma indenização financeira denominada de "pagamento de sangue" o valor é estipulado de acordo com a condição social do condenado 205 .

Órgãos internacionais ligados aos direitos humanos reprovam a aplicação destes castigos. A própria sociedade por não saber lidar com as diferenças e com situações extremas cria os estigmas e os definem como categorias ou classes, proibindo e monitorando as relações entre as classes e com o meio. As instituições ditam o que é "normal" ou "anormal", rotulando os corpos de acordo com suas "diferenças" ou "deformidades". Assim, são criados dois tipos de identidade social, a primeira real - aquela verdadeira, em que a pessoa se apresenta como ela é realmente, com todas as suas características; a segunda é a virtual - a idealizada, que está no imaginário, podendo se apresentar de forma negativa ou positiva ${ }^{206}$.

O estigma alcança todas as áreas na vida do estigmatizado, por estar em situação de desvantagem, incluindo o acesso à saúde. O indivíduo ou grupos estigmatizados têm o acesso à saúde reduzido e dificultado, principalmente porque os avanços nas políticas públicas sobre determinados temas incluindo a obesidade mórbida, distúrbios mentais, envelhecimento e outros, não são priorizados, e estes indivíduos são desrespeitados em seus direitos, bem como atingidos negativamente em sua dignidade e cidadania. Existem estigmatizados "invisíveis", isto é, aqueles que não possuem uma deformidade ou sinal físico aparente, como os ex-presidiários, os portadores de Disfemia (gagueira), que somente passam a ser estigmatizados quando revelam seus problemas ${ }^{207,208}$.

O ambiente estigmatizado se torna desfavorável para o sujeito que sofre o estigma e a discriminação, fragiliza os esforços de prevenção e promoção da saúde, enfraquece a capacidade dos sujeitos e seus familiares de se 
protegerem, inibe a coragem da revelação da doença e passa a ideia errônea de que a probabilidade de atendimento no serviço de saúde seja dificultado, aumentando assim o sofrimento do indivíduo ${ }^{209}$.

Alguns autores denominam esta vergonha por parte do estigmatizado de "estigma interiorizado" este estado psicológico impede que o sujeito busque e exerça seus direitos, o que os torna vulneráveis. Em casos que o sujeito já faz parte de um grupo que também sofre estigma como usuários de drogas, homossexuais e profissionais do sexo, isto reforça ainda mais o estereótipo. Segundo o Programa Conjunto das Nações Unidas sobre o $\mathrm{VIH} / \mathrm{SIDA}$ (ONUSIDA) (p.9) 209 "A discriminação é a aplicação do estigma. A discriminação consiste em ações ou omissões que derivam de estigma e que são dirigidas contra os indivíduos que são estigmatizados".

O estigma em relação ao obeso não difere da praticada em relação ao portador de outras doenças estigmatizadas, pois o estigma refere-se a qualquer atitude desfavorável, crenças ou comportamento direcionados às pessoas, seja no ambiente familiar, grupo social, trabalho ou comunidade. Além de passarem por dificuldades ao executarem atividades rotineiras na vida cotidiana, como subir escadas, amarrar os sapatos, não encontrar roupas com numeração específica, mobiliários não adaptados, barreiras físicas que impedem 0 direito de ir e vir, o obeso ainda tem que conviver com 0 preconceito, principalmente quando precisam utilizar serviços como transportes em geral, escolas, hospitais, utilizar equipamentos médicos de tamanho não adequados, bancos, academias, casas de show e outros.

O tema estigmatização ao obeso mórbido é de considerável relevância, pois este também faz parte da organização social e vêm enfrentado sérios problemas não somente biológico. A sociedade atual vê o obeso mórbido como algo marginalizado e descartável, por não se enquadrar nos padrões sociais de beleza, juventude e corpo sem gordura. Inúmeras pesquisas têm demonstrado que pessoas com obesidade não recebem promoções com facilidade em seus trabalhos por serem consideradas menos competentes que os magros ${ }^{210,-212}$. Muitos obesos acabam se isolando e evitando a exposição corporal ${ }^{213}$. 
É importante abrir discussões sobre o tema obesidade mórbida para criar entre os envolvidos uma integração social, pois o estigma causa transtornos na saúde do indivíduo. Por isto a discussão é necessária para que se entendam melhor as dificuldades e o impacto na vida daqueles que são estigmatizado. Segundo Brown ${ }^{214}$ algumas pesquisas mostraram que mulheres obesas têm mais problemas psicológicos que as de peso ideal. Outras pesquisas demonstraram que pacientes acima do peso recebem menos respeito por parte dos médicos, comprometendo assim a relação médicopaciente.

O planejamento de estratégias para combater a discriminação e a estigmatização é de fundamental importância, pois estes dois fatores estão correlacionados, seguem unidos e um legitima o outro, reforçando ainda mais a promulgação de ambos. As pessoas não precisam praticar diretamente atos discriminatórios para serem culpadas, as ações podem ser de omissão, permitir que o outro pratique, recusar a ajudar ou intervir no sentido de inibir estas ações, não informar ou vetar os direitos destes indivíduos, a discriminação alimenta o estigma, tornando-o cada vez mais forte ${ }^{209}$.

Onde existe a discriminação e o estigma também existe a ausência da prática dos direitos humanos. A igualdade, a liberdade, a autonomia, e todos os esforços para combater estes atos, até mesmo as declarações em prol da igualdade e da equidade entre os humanos tornam-se desacreditadas momentaneamente. O princípio da não-discriminação e não-estigmatização defendido pela DUBDH tenta proteger o ser humano de inúmeros atos discriminatórios, exigindo o respeito e tratamento igual perante a lei, assim bem como a punição aos que praticarem atos desumanos e degradantes.

Confrontar à discriminação e estigmatização é reforçar os direitos humanos, é tentar diminuir a vulnerabilidade dos sujeitos, tornando-os participantes dos ambientes sociais. O resgate destes indivíduos, antes rejeitados, traz um impacto positivo em suas vidas e de seus familiares, pois recuperam a autoestima, começam a participar do mercado de trabalho e conseguem recursos econômicos para cuidar da sua saúde e sustentar sua família, deixando de ser considerado um fardo. Resgatam a cidadania, 
participando e exercendo seus direitos políticos, econômicos, sociais, religiosos e culturais ${ }^{204,215}$.

As instituições de ensino devem investir no empoderamento dos alunos, principalmente das crianças, de seus direitos e seu papel na sociedade. Através da educação será possível convencer a sociedade que os grupos marginalizados podem e tem o direito de participar ativamente dos atos e da vida social, isto significa Não-discriminação e Não-estigmatização ${ }^{204,215}$. Por ser à educação um direito garantido pela Carta Magna brasileira, referida a todos os cidadãos independentes de classe social. A educação abre caminhos para que se alcancem outros direitos fundamentais, pois estimula 0 desenvolvimento psicológico, emocional e social, além de minimizar a exclusão de grupos vulneráveis. Uma sociedade que empodera seus cidadãos, se torna uma sociedade menos desigual e mais justa, promove e estimula a cultura de proteção da dignidade humana e respeito às diferenças.

É sabido que a discriminação, estigmatização e a intolerância têm sua raiz no âmbito familiar e seu reforço no âmbito escolar. $O$ encontro de diferentes pessoas em um mesmo ambiente traz, na maioria das vezes, o surgimento do diferente como cor da pele, sexualidade, gênero, cultura, forma de falar, de vestir, de se comportar, e também a forma como o corpo se apresenta (magro, gordo, alto, baixo, bonito, feio, completo, incompleto, portador de necessidades educativas especiais como surdez, cegueira, deficiência motora e entre outras) ${ }^{216}$.

Nestes casos, o ambiente educacional se torna o ambiente ideal para reflexão sobre estes temas e acima de tudo um espaço de confiança e de liberdade para expor sentimentos e inseguranças sobre o que é diferente. Sendo ainda a melhor forma de aproximar os diferentes e valorizar a diversidade de uma maneira presencial, diminuindo a distância causada pela tecnologia existente que por si só já é uma ferramenta de exclusão se mal utilizada ${ }^{216}$.

A educação preventiva trabalha na defesa da dignidade humana, garantindo direitos iguais e principalmente à liberdade, também estimula à 
solidariedade humana transformando pessoas em cidadãos capazes de respeitar as diferenças e manter uma convivência harmônica de forma a conseguir enxergar o melhor que o outro tem a oferecer. O papel do professor é inibir atitudes que desqualifiquem o outro, como proibir apelidos devido à condição corporal ${ }^{216}$.

A ideia é desmistificar o que a mídia enfatiza como o corpo perfeito, o professor se torna um suporte, um mediador e um interventor de maneira a sensibilizar o educando a não avaliar o outro somente pelo aspecto externo. Uma resposta a não-discriminação e não-estigmatização é a aceitação da presença de associações e Organizações Não Governamentais (ONGs) participando efetivamente das ações populares e das políticas públicas, pois estes representam grupos ainda rejeitados pela sociedade.

Os Direitos Humanos devem combater a discriminação e o estigma utilizando ferramentas legais de proteção dos sujeitos e abrir um novo caminho, oferecendo uma nova vida, tornando-os novos cidadãos, mantendo constante vigilância frente aos diversos ambientes, implementando programas coletivos com a participação da comunidade ${ }^{204,217}$.

Os agressores devem ser punidos legalmente como forma de resposta aos que transgridam os direitos do outro e da sociedade. Somente as leis não conseguem inibir ações como a discriminação e o estigma, elas são limitadas e devem se apoiar nos valores morais, nas expectativas dos grupos e comunidade, o ambiente familiar e social devem ser modificados para 0 combate destes atos ${ }^{217}$.

O monitoramento dos ambientes familiares também é importante porque o estigma muitas vezes acontece de forma velada e escondida dentro dos lares, por isto a importância dos profissionais da área da saúde como médicos, enfermeiros, assistentes sociais, agentes comunitários e a vigilância em saúde, assim bem como outros profissionais como professores que em algum momento conseguem penetrar dentro dos lares mesmo que indiretamente e perceber a presença do estigma e da discriminação ${ }^{217}$. 
O estigma e a discriminação não devem ser tolerados, proteger a vítima é fundamental, pois com o tempo a tolerância transforma-se em intolerância e traz a destruição do outro, por ser diferente. Deve-se trabalhar o conceito de identidade, estabelecer relações e atitudes de aproximação entre os diferentes, eliminar pensamentos de negação do outro. Transformar 0 ambiente democrático e semelhante, mostrar que o mundo tornou-se um ambiente plural e globalizado e que as vozes antes excluídas clamam para serem ouvidas e respeitadas ${ }^{215}$.

O Estado deve promover discussões sobre o tema e assumir uma postura de "Estado Intercultural" buscando assim eliminar as intolerâncias históricas referentes ao preconceito, estigma e discriminação. Reforçar a ideia de que vivemos em uma sociedade plural e que o estigma e a discriminação são atos que demarcam limites, criam fronteiras na construção da identidade. Muitas vezes o estigmatizado se torna intolerante e violento sendo fruto de um ambiente opressivo e salienta um pensamento de existência de uma sociedade que valoriza os desiguais, permite a predominância da exclusão e valoriza as relações e atitudes negativas.

A discriminação e o estigma rompem o processo de construção da identidade social do indivíduo, pois a identidade social é formada por preconcepções sociais, isto é, como somos percebidos pelo outro e como percebemos o outro. A presença da discriminação e estigma reporta a sociedade ao tempo medieval quando os diferentes eram violentados, intolerados e condenados a morte, como na inquisição ${ }^{204,215}$.

A bioética adota o tema não-discriminação e não-estigmatização como princípios que devem ser protegidos e praticados. A base da bioética está consolidada na forma multi, inter e transdisciplinar, o que envolve diferentes áreas do saber de maneira a buscar soluções e intervir na realidade social e vida cotidiana, por isto existe a necessidade de uma bioética de intervenção e de proteção dos vulneráveis conforme afirma Garrafa ${ }^{218}$.

A DUBDH consolida e reconhece que a saúde conforme conceituado pela OMS somente pode ser conquistada por meio da eliminação de múltiplos fatores que também fazem parte do processo saúde-doença. Os vulneráveis 
devem ser protegidos, pois muitos grupos ainda não possuem poder de fala, e precisam de que alguém fale por eles e não somente falem deles, e os diálogos bioéticos têm esta função social - dar voz aos "mudos sociais" 219,220.

A pessoa obesa está continuamente vulnerável, pois não há continuidade de programas e campanhas para a conscientização contra a discriminação e preconceito contra o obeso mórbido, o que limita o mundo destes cidadãos. O IMC somente não deve ser motivo de exclusão de um grupo, pois isto aumenta a estigmatização e a legaliza. Ao longo do tempo muitos grupos, dentre eles, os índios e negros eram considerados espécies inferiores por não se encaixarem em um padrão pré-estabelecido pelo grupo dominante. Outros critérios devem ser adotados para definir a capacidade intelectual, profissional e emocional de uma pessoa, a obesidade traz riscos à saúde, porém tratar o obeso de forma desigual é a concretização da discriminação, da opressão e do preconceito ${ }^{221,222}$.

Tribunais dos EUA e União Européia (EU), como exemplo a Corte Federal de Boston e a Corte de Luxemburgo passaram a reconhecer a discriminação sobre o obeso e para defendê-los resolveram incluir os obesos mórbidos como possuidores dos mesmos direitos reservados às pessoas consideradas incapazes ${ }^{223}$. Por ausência de leis específicas alguns países usam legislações análogas para defender direitos específicos de algumas pessoas.

Apenas para exemplificar até que ponto o ser humano pode exercer a discriminação e estigmatização de forma direta e brutal na vida de uma pessoa obesa, o caso será citado por ter tido repercussão mundial e ser exposto em jornais de diversos países. Fato ocorrido em outubro de 2014, na cidade de Nápoles na Itália, um adolescente de 14 anos foi agredido e violentado apenas por ser gordo, três homens casados que trabalhavam em um lava-jato ao verem o adolescente passar próximo ao estabelecimento, iniciaram as agressões de forma verbal e em seguida partiram para a agressão física, retiraram a roupa da vítima e introduziram um tubo de compressor de ar em seu ânus, ligaram o aparelho e causaram danos no intestino, ficando este em estado grave, quando socorrido foi submetido a uma cirurgia de mais de cinco 
horas para reconstrução do tubo intestinal, ficando internado por 17 dias. $O$ caso ficou conhecido publicamente, sendo o jovem visitado pelo Papa Francisco 224 .

Como consequência do estigma as relações sociais ficaram comprometidas, o outro passou a ser algo perigoso e a relação tornou-se impessoal. A convivência é quase que imperceptível, a vida social é praticamente nula, as oportunidades profissionais são restritas. $O$ indivíduo perde a identidade social, muitas vezes deixando de "existir". Existem pessoas possuidoras de estigmas físicos, mas por ter prestígio e uma posição social elevada, isto torna sua condição aceitável até certo ponto "despercebido" por uma sociedade capitalista.

O estigmatizado tem uma área de locomoção e ação limitada, quanto mais visível sua marca ou sinal, mais maléficos são seus efeitos. A família e a escola são as instituições sociais que tem inicialmente mais acesso ao psicológico destes indivíduos podendo dar proteção, apoio e socializando-os por meio de reflexões sobre o tema com o objetivo de construir e descontruir conceitos e preconceitos, principalmente sobre outro. A discriminação apesar de antiga tornou-se atual por ter se revestido de um nome mais moderno o Bullying ${ }^{206,207}$. Segundo Leão ${ }^{225}$ (p.119) o bullying é um fenômeno que:

(...) apresenta-se de forma velada, intencional e repetitiva, dentro de uma relação desigual de poder, por um longo período de tempo contra uma mesma vítima, sem motivos evidentes, adotando comportamentos cruéis, humilhantes e intimidadores, gerando consequências irreparáveis, sejam elas físicas, psíquicas, emocionais ou comportamentais.

O fenômeno bullying atinge qualquer indivíduo, em todas as idades e classe social, não se limita apenas à escola, mas pode ocorrer em diferentes ambientes em que haja relação entre o agressor e agredido, como por exemplo, o ambiente familiar, de trabalho, ambiente carcerário, clubes, igrejas, universidades. O bullying ultrapassa as brincadeiras entre colegas, e muitas vezes por ser confundida como mera brincadeira passa despercebido e ignorado pelos demais sujeitos, até mesmo em alguns casos pelo próprio ofendido ${ }^{225}$. 
As pessoas obesas ou acima do peso sempre foram vítimas de bullying, seja de forma velada ou direta. Um exemplo comum é se dirigir a pessoa utilizando o diminutivo "gordinho" ou "gordinha", fazer piadas, apelidar com palavras que determinam características físicas. O bullying nada mais é que intimidar, humilhar, exercer o poder sobre o outro de forma a perseguir e menosprezar. $O$ indivíduo obeso perseguido pode desenvolver comportamentos de risco como alcoolismo, tabagismo, bulimia e anorexia, no intuito de fugir da realidade e/ou tentativa de mudar o estilo de vida para se enquadrar em um padrão imposto pela sociedade ${ }^{226,227}$.

As barreiras impostas pela obesidade na vida do indivíduo ao longo do tempo, como: brincadeiras relacionadas ao excesso de peso, indiferença, baixa estima, isolamento social e familiar e depressão, são os principais motivos para a busca da CBM, a questão saúde às vezes pode ficar em segundo plano. Sendo observado em alguns estudos que a busca por este tratamento não se restringe apenas aos adultos, mas, os adolescentes também estão procurando este procedimento como solução para problemas como o bullying ${ }^{227,228}$. Contudo, a legislação brasileira somente permite o procedimento em maiores de 16 anos, abrindo exceção na infância apenas de forma experimental.

Diante de toda esta explanação sobre obesidade, CBM e bioética, é importante destacar as falas de alguns especialistas e estudiosos da ética e da bioética. A intenção é expor as diversas discussões, introduzir outros nomes além dos já conhecidos e abordados com frequência nos ambientes bioéticos, também despertar na sociedade e em pesquisadores a ideia de que a obesidade e a CBM podem ser percebidas de diversos ângulos, pois é isto que a bioética traz, um olhar diferenciado, a percepção de um mundo que possui inúmeras facetas, assim se inicia os longos diálogos bioéticos. 


\subsection{OBESIDADE NO CAMPO DA ÉTICA E BIOÉTICA}

As discussões sobre os impactos sociais da obesidade têm ocorrido de forma lenta por pesquisadores da área de sociologia, antropologia, por agentes envolvidos com saúde pública e com políticas públicas desde a década de 1980. De acordo com Mayes ${ }^{229}$ os bioeticistas têm se mantido quase que em silêncio em relação ao tema. Sendo que esta questão faz parte das discussões da bioética, desde sua origem, por estar envolvida em questões relacionadas à qualidade de vida, vulnerabilidade, exclusão e inclusão social, à alocação de recursos na saúde e tecnologia em saúde.

Existem muitos filósofos e pesquisadores em todo o mundo que discutem o tema alimentação, obesidade e fome, porém o filósofo que tem tido maior destaque nas questões alimentares e da obesidade pelo fato de defender ideias utilitaristas e ser bastante polêmico em seus argumentos é Peter Singer, envolvido em discussões polêmicas sobre inúmeros assuntos incluindo a obesidade e outros temas que a circundam como a fome, a indústria alimentícia, a economia, a política e a cultura. Singer não é a referência principal sobre o tema obesidade, mas tem um papel importante no despertar das discussões no campo da bioética.

Singer iniciou a discussão sobre a ética alimentar em 1975 com a publicação do livro "Libertação animal", orientando a adoção de uma dieta moral, estimulando a adoção do vegetarianismo, mas sem imposição, afirmando que diante das diversidades de alimentos, as pessoas podem fazer escolhas baseadas na ética alimentar, isto é, que podem ser razoáveis quanto a escolha dos alimentos, consumindo produtos orgânicos produzidos de forma a não prejudicar o ambiente ${ }^{230}$.

Sobre a ética da obesidade Singer inicia afirmando que a igreja nos últimos tempos tem enfatizado mais o pecado exacerbado em relação ao apetite sexual do que pela comida, com isto seus seguidores estão ficando obesos. Destaca a importância da religião no controle da obesidade, quando orientam que as pessoas devem controlar seus apetites e devem somente comer o que precisam e que esta atitude faz bem para a saúde e para o meio ambiente. $\mathrm{O}$ autor afirma que existe algo de errado no mundo, quando uma 
parte da população luta contra a fome e a outra luta contra a obesidade. Defende os alimentos transgênicos quando cita que estes podem ser uma solução ao combate a obesidade e a fome no mundo ${ }^{230-232}$.

Peter Singer se define um "utilitarismo de preferências" em que as ações e consequências dos atos individuais e coletivos devem priorizar o bem da maioria, seja em relação a humanos ou não. Afirma que um juízo ético para ser emitido necessita de um ponto de apoio denominado "igualdade de interesses" um interesse individual não deve ser mais importante que os interesses do coletivo ${ }^{227}$.

Partindo deste pensamento de priorizar os interesses coletivos, Singer debate as ditas "mazelas sociais" como a fome, a pobreza, a riqueza, as guerras e a obesidade presentes no planeta Terra. Declara que todos nós temos a obrigação de ajudar o outro; que nós podemos impedir que coisas ruins aconteçam e que a pobreza absoluta pode ser combatida sem que a moral seja sacrificada. Se baseando na teoria da responsabilidade que nenhum indivíduo é autossustentável e absolutamente independente, pois em algum momento precisa interagir com o outro, pois o homem é um ser social. Não basta viver de modo a não interferir na vida do outro, é necessário lutar pelo direito à vida das pessoas que podem a vir a morrer por danos evitáveis ${ }^{159,234}$.

É evidente que Singer rompe as barreiras tradicionais da ética, causando ódio e aguçando interesses antes considerados utópicos porque aborda problemas reais e cotidianos e tenta dar soluções práticas a elas. Mostrando que o importante não é perguntar como resolver o problema, mas como evitar novos acontecimentos e imprevistos que são previsíveis. Afirma que o homem come demais, de forma desnecessária, e isto causa impactos no ambiente e na sociedade, afirmando que a obesidade interfere diretamente na saúde pública ${ }^{234}$.

De acordo com Singer ${ }^{234}$ as pessoas devem mudar o comportamento, parar de pensar nos alimentos como algo que somente é gostoso e faz bem. Devem perguntar qual a consequência daquele alimento no organismo e para o meio ambiente. A forma como a pessoa se alimenta traz impacto em sua própria vida, a obesidade é um exemplo disto. O primeiro passo para a 
mudança de comportamento do consumidor em relação a suas escolhas é a educação. É necessário conhecer todo o processo de produção dos alimentos até chegar as suas mesas. Se existe um produto é porque existe um consumidor, quem muda o mercado é o consumidor.

Em 2011 o epidemiologista em nutrição Barry Popkin ${ }^{235}$ (p.1) afirmava que existiam mais pessoas obesas no mundo do que as que passavam privação de alimentos. Conforme citação a seguir:

(...) nas décadas de 1960 e 1970 a fome e a pobreza eram os maiores problemas - tanto nos Estados Unidos quanto no exterior. Na década de 1980 o problema da obesidade começou a assumir o lugar do problema da fome nos EUA e na Europa, mas a fome continuou sendo um problema sério nos países em desenvolvimento. Hoje, porém, a obesidade é um problema de proporções epidêmicas no mundo inteiro.

A preocupação dos pesquisadores hoje é estudar o novo paradoxo nutricional e combater a má alimentação, sedentarismo, a fome e a obesidade, o "monopólio da fome" não pertence mais aos pobres, pois estes também estão ficando obesos. Os EUA é considerado o país mais rico e poderoso do mundo, e também alcançou o de mais gordo ${ }^{235}$.

Entre os anos de 2012 e 2013 os bioeticistas Peter Singer ${ }^{236}$ e Daniel Callahan ${ }^{237}$ abordaram o tema obesidade incluindo-o em debates bioéticos, ambos argumentaram que a obesidade não é somente uma questão fisiológica, isto é clínica, ou individual, afirmaram que a obesidade é uma questão ética com consequências sociais e políticas porque traz danos negativos para a sociedade e para a saúde pública.

Duas justificativas são defendidas por Singer e Callahan: 1) partem do princípio que os indivíduos são agentes autônomos responsáveis pelos efeitos em sua saúde a partir de suas escolhas alimentares, os indivíduos são obesos porque escolhem determinados alimentos de forma irresponsável e não praticam atividade física; 2) reconhecem que os indivíduos são livres para fazer suas escolhas desde que não prejudiquem os outros, neste sentido, a partir do momento que $o$ indivíduo obeso interfere na liberdade do outro, o outro pode legitimamente invocar o princípio do dano ${ }^{236,237}$. (Grifo do autor) 
Callahan ${ }^{237}$ declara em seu artigo "Obesity: Chasing an Elusive Epidemic"4 que a obesidade tem crescido em todo o mundo, e nos EUA não tem sido diferente, sendo este o primeiro no "rank", a condição de obesidade se tornou um produto da cultura americana, sendo quase impossível seu combate, podendo ser considerada o problema de saúde pública mais difícil de ser resolvido, devendo ser adotadas estratégias ousadas para controle. Os tratamentos médicos disponíveis atualmente não conseguem controlar 0 avança da condição obesidade até o momento.

As comorbidades associadas podem ser tratadas e controladas, porém a obesidade ainda é de difícil tratamento devido à baixa adesão porque envolve mudança de comportamento, de hábitos alimentares, de estilo de vida e do comércio de alimentos e bebidas, comportamentos estes que estão enraizados na sociedade. As ideias de Callahan são baseadas na progressão e nos custos globais da obesidade, afirmando que não é possível chegar a um número exato por ser o cálculo bastante complexo, contudo pode ultrapassar os custos com outros fatores semelhantes como estresse e tabagismo, que são estimados em dezenas ou centenas de milhares de dólares ${ }^{237}$.

Callahan ${ }^{237}$ lança alguns questionamentos: $O$ quão dispostos estão os governos e as indústrias em tentar mudar o comportamento social que prejudica a saúde? Quais limites serão impostos às indústrias? Como olhar para nossos corpos e julgar os dos outros?. E como resposta, ele afirma que 0 Estado deve atacar a obesidade em três frentes: 1) Implementar medidas econômicas fortes, adequadas e coercivas na saúde pública, o Estado deve se comportar diante desta epidemia e dos gastos atuais, de maneira a criar políticas públicas, como por exemplo, aumentar as alíquotas sobre determinados produtos e alimentos, como o açúcar e "fast-food", e em alguns casos proibir a venda de certos produtos que prejudicam à saúde; 2) Elaborar programas de prevenção da obesidade infantil, trabalhos de educação infantil nas escolas, estimulando alimentação saudável; 3) Pressão social sobre a obesidade, criar estratégias de "oprimir" ou "estigmatizar" a pessoa obesa, ao ponto desta sentir vergonha desta condição.

\footnotetext{
${ }^{4}$ Tradução da própria autora. Obesidade: perseguindo uma epidemia ilusória
} 
As pessoas que ainda não reconheceram seu estado de obesidade devem ser despertadas para a realidade, isto é, um choque de reconhecimento. A abordagem contra a obesidade deve ser ousada, citando a campanha antitabagismo como um exemplo de "estigmatização light" que teve resultados positivos na saúde pública. A intenção é estigmatizar o indivíduo deixando bem claro que seu comportamento não é saudável e sua atitude é reprovada pela sociedade. $\mathrm{O}$ autor reconhece que o estigma causa danos e aumenta os riscos de discriminação, mas defende que o "estigma light" se bem utilizado pode fazer com que o indivíduo previna a obesidade com medo da discriminação social. Ainda alerta sobre a importância das estratégias de saúde pública, das leis e do governo subsidiar alimentos saudáveis, priorizando a alimentação infantil $^{237}$.

Em 2012 Singer ${ }^{236}$ escreveu um artigo "Weigh More, Pay More"5 que causou espanto e gerou inúmeras críticas quanto a sua opinião em relação às pessoas obesas. Inicia o texto alertando para o aumento do número de obesos em todo o mundo, tendo iniciado pelos países ricos e agora chega aos países em desenvolvimento e pobres. Também faz um comentário que as pessoas estão tão gordas que ao invés de andar elas "bamboleiam", elas não andam, elas "rolam". Singer faz alguns questionamentos sobre a pessoa obesa: O peso de uma pessoa só a ela diz respeito? Devemos simplesmente nos tornar mais tolerantes quanto à diversidade de formas corporais?. O autor ressalta que a obesidade é um assunto ético e que o aumento do peso corporal significa custos e danos para os outros.

$O$ artigo foi escrito no saguão de um aeroporto enquanto o autor esperava para embarcar, Singer observou uma fila de "check-in", começou então a escrever que existem passageiros que pesam mais que o peso de suas bagagens. Começa então, a fazer um paralelo entre os passageiros que possuem peso normal, mas que pagam tarifas por excesso de peso de suas bagagens, e os passageiros com excesso de peso corporal, mas que suas bagagens não excedem o peso determinado e assim não precisam pagar tarifas de excesso de peso ${ }^{236}$.

\footnotetext{
${ }^{5}$ Tradução da própria autora: Pesa mais, Paga mais.
} 
Concluindo, após a observação que, o avião terá da mesma forma um gasto maior de combustível, independente se o excesso de peso provém da bagagem ou do corpo do indivíduo. As pessoas obesas custam caro, elas drenam os recursos, não é somente o aumento de combustível, mas também o custo ambiental com a eliminação da emissão de gases, as empresas de transportes públicos têm custos com as adaptações, assim como os hospitais que necessitam adquirir equipamentos de tamanho adequado e mais resistentes como camas, mesas cirúrgicas, cadeiras, geladeiras em necrotérios, instalações de banheiros, entre outros ${ }^{236}$.

Algumas companhias aéreas australianas e americanas já praticam e outras estudam a cobrança de tarifa por excesso de peso corporal, determinando um peso padrão para voar sem custos de adicionais, caso contrário serão cobradas sobretaxas. Balanças seriam utilizadas para pesagem humana, assim como já ocorre com a bagagem. Cobrar tarifa de sobrepeso não é punir ou discriminar, é apenas cobrar os custos extras das empresas em consequências do excesso de peso, permitindo que o passageiro chegue ao seu destino final ${ }^{236}$.

Existem autores contrários aos pensamentos de Callahan e Singer. Barbezat ${ }^{238}$ afirma que Callahan com certeza tem boas intenções com suas ideias, principalmente por reconhecer que a obesidade é sim um problema de saúde pública e de difícil resolução, porém as ações propostas por ele não trarão os benefícios esperados que é uma população com menos peso, saudável e feliz. A primeira proposta (medidas coercivas na saúde pública) atingiria a população mais pobre que não tem acesso a produtos caros, saudáveis e nutritivos. Então seria uma punição somente as classes menos favorecidas, pois os ricos continuariam a ter acesso aos produtos que prejudicam à saúde e levam à obesidade.

Em relação aos programas de prevenção à obesidade infantil o autor apenas reforça que a educação deve promover, criar e manter ambientes saudáveis, e que a indústria de engenharia de alimentos devem produzir alimentos compatíveis com as necessidades do organismo humano, ao contrário do que acontece atualmente em que investimentos cada vez maiores 
são realizados com o intuito de descobrir novas texturas, novos sabores que agradem o consumidor, utilizando mais açúcar, mais sal, gorduras e conservantes $^{238}$.

Porém, sobre a terceira proposta é extremamente contra a criação de ambientes estigmatizantes, pois afirma que esta ideia ultrapassa a barreira da ética, da saúde e da felicidade. Envergonhar as pessoas ou fazer com estas se envergonhem de si mesmas, pode até diminuir o peso corporal, porém os custos com a saúde continuarão a aumentar devidos problemas de baixa autoestima, provocando mais sofrimento. Barbezat ${ }^{238}$ faz alguns questionamentos sobre os objetivos das ideias de Callahan: Criar ambientes estigmatizantes? Causar sofrimento? Punir? Ou políticas que estimulem a criação de ambientes e pessoas saudáveis?

Os pobres estão ficando obesos devido uma queda nos valores dos fastfood e bebidas açucaradas (sucos e refrigerantes) enquanto as frutas e vegetais são mais caros, quanto mais barato o produto maiores são as quantidades de calorias presentes. Segundo Barbezat ${ }^{238}$ ter acesso a alimentos saudáveis e nutritivos necessitam de rendas maiores. A contraproposta seria incentivar uma alimentação saudável, sendo o Estado responsável por subsidiar estes alimentos, como frutas e verduras de preferência orgânicos evitando uso de agrotóxicos que contaminam o meio ambiente e causam doenças, ao invés de aumentar os custos para quem não pode pagar muitas vezes o mínimo.

Mayes $^{229}$ também faz uma crítica sobre os argumentos de Singer e Callahan, afirmando que o princípio do dano deve ser evocado e reconhecido, desde que seja baseado em investigações epidemiológicas sobre os danos causados por indivíduos obesos que vão sinalizar os determinantes sociais como causa da obesidade.

Reconhecer a autonomia de escolha do indivíduo sobre seus alimentos e a não realização de atividade física, são argumentos que de forma isolada não justificam intervenções. As investigações devem incluir o próprio indivíduo obeso e os agentes envolvidos em atividades que direta ou indiretamente causam a obesidade. Mayes ${ }^{229}$ afirma ainda que os bioeticistas devem se 
envolver em questões que antecedem a clínica, como por exemplo, os determinantes sociais da saúde, esta abordagem deve ser de forma ampliada, utilizando ferramentas diversificadas e interdisciplinar.

As pessoas que possuem uma condição ou doença crônica específica devem ser julgadas ou não por estarem nestas condições, já que são responsáveis pelas escolhas alimentares? Esta pergunta tem sido feita por especialistas médicos e não-médicos que argumentam que o indivíduo tem obrigação de fazer escolhas alimentares saudáveis, isto significa a moralização do uso de alimentos e da saúde nutricional. Contudo, este argumento confronta a liberdade de escolha, colocando uma obrigação moral sobre a pessoa, e abre margem de discurso sobre o significado de "saudável" ${ }^{239}$.

Singer ${ }^{236}$ compartilha semelhantemente das ideias de Callahan ${ }^{237}$, apoiando a coerção como estratégia de inibir a obesidade. Como o caso em que defende as companhias aéreas de cobrar mais para quem pesa mais, justificando que o peso é um negócio, que a obesidade é um problema ético e que gera custos para os demais cidadãos. Baseado nas despesas anuais com cuidados com a saúde das pessoas com sobrepeso e com os custos gerados pela perda de produtividade laborativa por incapacidades causadas pela obesidade, totalizando aproximadamente 115 bilhões de dólares por ano, somente isto é suficiente para justificar políticas públicas para inibir o comportamento de ganho de peso, pois quem paga a conta são todos os contribuintes.

Para Singer ${ }^{236}$, o correto seria aumentar os tributos dos alimentos que auxiliam no ganho de peso, sem valor nutricional. Isto inibiria o consumo, a arrecadação destes impostos deveria ser revestida para programas antiobesidade. A população mundial já ultrapassou os sete bilhões é necessário pensar não somente em números de indivíduos, mas na massa destes indivíduos, a ocupação de espaço destes indivíduos. Quando se pensa e discute tanto em qualidade de vida, sustentabilidade e meio ambiente, o meu peso deve ser questionado, tornando-se assim um assunto a ser discutido na coletividade. 
O indivíduo não pode agir de forma indiscriminada e deixar os custos com o outro, exemplos práticos, são os que possuem comportamento sexual de risco, podendo adquirir doenças sexualmente transmissíveis deixando os custos com o tratamento como ônus para a sociedade, acontece o mesmo com os tabagistas que adquirem doenças crônicas e terminais, assim bem como os casais que por uma decisão particular geram muitos filhos, utilizam os recursos oferecidos pelo governo e não pagam mais impostos por isto, sendo este mais um ônus para a sociedade. Existem inúmeros casos que poderiam ser citados, a lista é extensa, a conclusão é, de que alguém paga a conta ${ }^{240}$. Ao expor suas ideias Singer desperta os estudiosos para algo novo e com um olhar mais realista quando relaciona alimentação à política, à ética, à saúde e ao meio ambiente.

Smith ${ }^{241}$ critica Singer sobre suas ideias utilitaristas por este não acreditar nos direitos individuais, por defender que a sociedade tem o direito de impor regras em relação à vida do outro, inibindo, punindo, proibindo e controlando certos comportamentos, mesmo que por meio de sofrimento, isto atinge principalmente pessoas vulneráveis, desfavorecidas de poder. As pessoas que simpatizam com as ideias de Singer estão declarando que o governo tem o poder de interferir nas escolhas individuais. O Estado não tem o direito de impor o que devemos comer ou como devemos agir. O peso corporal não pode ser explorado comercialmente. Para Peter Singer a liberdade coloca as pessoas em risco. Para que o Estado mantenha controle sobre o individuo, existem questionamentos, como por exemplo: Quem seriam controlados? De que forma seria este controle? e, Qual o limite deste controle?.

Outros autores como Marion Nestle e Michael Pollan têm criticado a indústria alimentar como sendo responsável pelo aumento da obesidade oferecendo produtos não saudáveis. Ambos afirmam que ao escolher os alimentos não se deve levar em consideração somente o preço, mas deve-se considerar a moral. Em sua obra "Food politics: How the food industry influences nutricion and health" ${ }^{\text {" }}$ revelam os bastidores da publicidade $\mathrm{e}$ propaganda dos alimentos e a competição feroz da indústria de alimentos,

\footnotetext{
${ }^{6}$ Tradução da autora. Política de alimentos : Como a indústria alimentar influencia na nutrição e saúde.
} 
como funciona e como isto interfere na saúde das pessoas. A luta do mercado para que as pessoas consumam mais e mais, comam com maior frequência e em maior quantidade, não importando com suas "cinturas" ou com seu bemestar. A comida é um grande negócio, assim como a indústria bélica e do tabaco 242 .

Pollan ${ }^{242}$ critica a indústria alimentar alegando que esta tem apenas um objetivo o de "engorda", afirmando que as pessoas quando vão aos supermercados, restaurante e fast-food não estão comprando de fato alimentos, são produtos manipulados, alterados geneticamente, com excesso de açúcares, critica também o consumo de carne. O autor orienta as pessoas a voltarem no tempo e se alimentarem semelhantemente aos antepassados.

Os autores criticam a indústria alimentícia por se associarem as autoridades governamentais por meio de "lobbys", e vice-versa, com o objetivo de ampliar negócios na publicidade e vendas de alimentos infantis, a indústria alimentar é extremamente política e suas estratégias não estão expostas ao público, as prateleiras dos supermercados escondem um labirinto de influências, planos de consumo em massa baseados na economia e aumento de capital e não na saúde. A intenção é despertar os leitores e consumidores a se informar e ter sabedoria na escolha dos alimentos justificando que a nação mais rica do mundo está morrendo de tanto comer ${ }^{242}$.

Para Ross as pessoas obesas devem ser ouvidas e precisam declarar se querem ou não perder peso, seja por questões de saúde ou estética. A abordagem da moralidade sobre o obeso não deve ser imposta e os médicos devem reavaliar suas condutas de maneira imparcial. A informação deve ser um meio utilizado para tirar dúvidas sobre hormônios da fome, sobre calorias, alimentos, sobre produtos químicos que causam dependência e que são usados na fabricação de alimentos, meios de como reverter à adiposidade. A educação é a melhor maneira de intervir e golpear a obesidade, não permitir a publicidade de curas milagrosas para a eliminação de gorduras indesejadas. Educação alimentar e redução dos custos finais de alimentos nutritivos para o consumidor é uma das soluções para diminuir o crescimento da obesidade ${ }^{243}$. 
Discutir a moralidade em torno da obesidade é ultrapassar fronteiras entre a medicina e a fraqueza moral. A medicina tratar a obesidade como doença é um fato concreto, mas quando se trata da moralidade, a metafísica é invocada e trabalha-se com evidências empíricas. As pessoas não são autônomas e responsáveis pelo que colocam em suas bocas, são vítimas de algo que vai além do controle humano individual, a comunicação por meio da publicidade e propaganda tem sua porcentagem de culpa. Na questão obesidade o único princípio moral e vital é não estigmatizar o obeso, pois existe neste caso a inversão causal, a pessoa gorda que sofre estigmatização é estimulada a comer mais por sentir-se mal por ser gordo ${ }^{243}$.

O documentário "The Weight of the Nation" ${ }^{17}$ explica consequências do excesso de peso para a saúde, quais as tecnologias disponíveis para pesquisas de medicamentos e os custos, quantos milhões de dólares são gastos por ano em pesquisas e mostra que até o momento não existe nenhuma medicação altamente eficaz para prevenir ou reverter a obesidade. Alguns especialistas relatam que as crianças estão sendo afetadas pela obesidade e que esta pode ser a primeira geração de crianças americanas que terão uma expectativa de vida curta em decorrência dos males causados pela obesidade. O documentário faz um alerta da gravidade da obesidade e alerta as comunidades a lutar contra esta epidemia ${ }^{244}$.

O economista Edward Hadas afirma que a obesidade é uma questão de escolha, pois ninguém obriga o outro a engordar. Nem a ciência nem o mercado pode substituir a força de vontade. As pessoas têm liberdade de escolher seus alimentos devido à liberdade econômica, enquanto no século XVIII muitos eram privados dos alimentos, agora tentam compensar desfrutando do excesso de comida, principalmente nos países desenvolvidos e em desenvolvimento. $O$ alimento não está sendo usado para saciar a fome e sim para saciar o prazer. Não basta contar calorias, ler rótulos e evitar "junkfood', as pessoas precisam realmente ter autocontrole e moderação no ato de comer $^{245}$.

\footnotetext{
${ }^{7}$ Tradução da autora: 0 peso da nação.
} 
As indústrias alimentícias em conjunto com as fábricas publicitárias, principalmente às que produzem e divulgam produtos direcionados ao público infantil têm suas parcelas de responsabilidades no aumento da obesidade, pois trazem personagens dos desenhos infantis para compor as ilustrações presentes nas embalagens e em forma de bonecos e outros brinquedos vendidos de forma conjugada com o alimento, quase que $80 \%$ das propagandas infantis estão relacionadas à guloseimas. Segundo o Painel Nacional de Televisão do lbope, em 2005 as crianças brasileiras ficaram expostas aos conteúdos direcionados a elas em média 4 horas, 51 minutos e 19 segundos por dia, ultrapassando as horas gastam na escola ${ }^{246,247}$.

As crianças ainda não possuem maturidade cognitiva para se defender das armadilhas do "marketing", o máximo que conseguem diferenciar é qual o brinquedo que mais the agrada ${ }^{246}$. O uso abusivo dos aparelhos eletrônicos, como televisão, tablets e smartphones também trazem desvantagens à saúde e a qualidade de vida ${ }^{248}$. A força do "marketing" é tão grande e desastrosa que veda os olhos dos cidadãos restringindo a capacidade de pensar, manipulando e dominando o mercado alimentar, afetando a autonomia do indivíduo e corrompendo questões morais da área alimentar e social ${ }^{249,250}$.

As empresas americanas gastam mais de 15 bilhões de dólares por ano com publicidade infantil para criar a cada ano consumidores fiéis e insaciáveis desde o berço até o túmulo. Influenciado ao ponto de sufocar os valores morais e éticos ensinados pela família e sociedade em relação ao consumo inteligente e nutricional. Sendo capaz de mudar a cultura do vestir, do comer, do brincar e contribuindo para o aumento da obesidade, da violência, dos distúrbios alimentares, do uso de drogas e da sexualidade precoce. Os pais sozinhos não conseguem impedir a influência da mídia e da indústria alimentícia sendo necessário o auxílio dos profissionais de saúde, educadores e de legislações mais rigorosas 251,252 .

Conforme afirmam Cohen ${ }^{249}, \mathrm{Keon}^{250}$ e Robbins ${ }^{253}$ que não há neutralidade científica quando os negócios que envolvem os interesses das grandes empresas e marcas mundiais de alimentos estão em jogo. Como aconteceu com os produtos derivados do tabaco que tinham laboratórios, 
profissionais médicos, mídia, financiados pela indústria do tabaco, que acobertavam os males causados pelo cigarro, até que alguns cientistas contrários ao fumo conseguiram romper a barreira da econômica e da publicidade, comprovando e divulgando que muitos cânceres surgiam em consequência da inalação da fumaça do cigarro que contem inúmeras substâncias químicas danosas ao organismo humano.

As doenças provenientes do consumo de alimentos com excesso de açúcar, sal e gorduras são convenientes para a indústria farmacêutica, a venda de medicamentos para diabetes, hipertensão e outros de uso contínuo ainda são "carros chefes" para o mercado farmacêutico, o que confirma ainda mais a associação de interesses mesmo que indiretos das indústrias farmacêutica e alimentícia. Quantos médicos são financiados por laboratórios, em suas viagens a congressos para o exterior, em troca de prescreverem determinados medicamentos, solicitarem exames e procedimentos muitas vezes desnecessários. Afirma Schmid que não é a ciência nutricional que domina 0 mercado e sim a indústria alimentícia que determina padrões alimentares ${ }^{254}$. 


\subsection{CIRURGIA BARIÁTRICA E METABÓLICA NO CAMPO DA ÉTICA E BIOÉTICA}

Somente a medicalização não é mais suficiente para combater a propagação da obesidade, sendo necessário adotar estratégias mais radicais para tentar minimizar os danos causados pelo excesso de peso na população. Nos debates públicos ocorrido em todo o mundo sobre obesidade tem-se questionado se a obesidade deve ser entendida apenas como doença ou deve ser associada a um problema de comportamento ${ }^{255}$.

Por ser a obesidade uma doença multifatorial, a CBM não deve ser vista como um tratamento rápido e eficaz para o problema, pois envolve não somente as alterações gastrointestinais, psicológicas, de estilo de vida, de hábitos alimentares, envolve também questões políticas, econômicas, sociais, culturais, religiosas, éticas e bioéticas. Os bioeticistas devem obrigatoriamente se envolver neste tema, por apresentar inúmeros aspectos questionadores que seriam impossíveis de serem tratados neste estudo, contudo as falas de estudiosos do campo da ética e principalmente da bioética serão abordadas permitindo assim a possibilidade de penetração e interferência da bioética dentro de um procedimento que envolve ciência e tecnologia em saúde mostrando que a bioética é sim multi-inter e transdisciplinar.

A medicina atual permite alterar a anatomia e fisiologia na tentativa de ajudar, contudo envolve alterações definitivas no corpo humano, e isto envolve implicações éticas, que por meio da bioética podem ser monitorados e discutidos os excessos e riscos presentes nestes novos procedimentos. A bioética é uma disciplina teórico-prática que diante de problemas emergenciais ou não, procura orientar sobre a melhor ação, de acordo com as convicções éticas e morais envolvidas, baseadas na prática do bem e do mal, da lei, da beneficência, da não-maleficência, da autonomia, da justiça e principalmente em prol da vida e do bem da sociedade.

Klugman ${ }^{256}$ critica o uso do procedimento CBM em crianças, definindo o ato como "ultrajante e até chocante" alegando ser um procedimento ruim e extremo. O autor critica um caso específico publicado no International Journal 
of Surgery Case Reports ${ }^{257}$ em 2013 de uma criança (menino) chamado Mohammed Al Mohaidlya de dois anos de idade, residente na Arábia Saudita, que sofria de obesidade mórbida pesando 33 quilos, com IMC de $41 \mathrm{~kg} / \mathrm{m}^{2}$, que apresentava apneia do sono e problemas ósseos como curvatura anormal dos membros inferiores devido ao peso corporal, foi submetida ao procedimento em 2010.

Segundo o estudo os pais alegaram duas tentativas com outros tratamentos convencionais com restrição alimentar, porém sem êxito, tendo aumento de peso mesmo com a dieta. Não foi relatado uso de medicamentos como tratamento e após exames (hormonais e genéticos) foi descartada a presença de síndromes, contudo os médicos não tinham a certeza absoluta que os pais realmente seguiram a dieta prescrita à criança. Os médicos decidiram optar pela cirurgia radical e irreversível por meio de uma gastrectomia laparoscópica, removendo parte do estômago. Dois meses após o procedimento a criança perdeu $15 \%$ do peso corporal, chegando em dois anos a um IMC de $24 \mathrm{~kg} / \mathrm{m}^{2256}$.

Foi o primeiro procedimento do gênero a ser realizado em criança relatado na literatura mundial. O procedimento foi tecnicamente bem sucedido, porém como afirma Klugman ${ }^{256}$ e outros especialistas, isto é um ato incomum, mas aparentemente os médicos que realizaram o procedimento estavam tendenciosos a realizá-lo e precisavam de uma oportunidade. Nenhum relatório posterior foi divulgado para análise do desenvolvimento cognitivo e de crescimento. Contudo, não se pode afirmar se houve negligência dos médicos ao realizar o procedimento porque são três profissionais e no artigo relatam inicialmente a obesidade como uma doença e epidemia, e as consequências dos riscos da obesidade, contudo o artigo é tendencioso, pois implicitamente percebe-se que não houve um esforço de tratamento que não fosse o cirúrgico.

A critica de Klugman ${ }^{256}$ é centrada nos efeitos colaterais da CBM que sempre estão presentes. Os riscos imediatos oriundos da anestesia e de hemorragias durante $\circ$ procedimento, ainda 0 refluxo gastroesofágico, Síndrome de Dumping, deficiências nutricionais de vitaminas, minerais, proteicos, risco de cálculo biliares e outros. Se em um adulto já é considerado 
um grande problema, como lidar com estes instalados em uma criança, até que ponto influenciará no crescimento e desenvolvimento, quais os danos reais. Klugman questiona: os pais e os cirurgiões são loucos?.

A Convenção das Nações Unidas Sobre os Direitos da Criança declara que os pais devem pensar sempre no melhor interesse para a criança, oferecendo adequado ambiente, alimentação, educação, amor e boa saúde. A Arábia Saudita é um signatário da ONU embora aceite a realização de práticas condenáveis em crianças e adolescentes. A parte mais triste desta história segundo Klugman ${ }^{256}$ é que no mundo existe uma criança alterada cirurgicamente para toda a vida, sem ter tido acesso as outras opções de tratamentos alternativos, deixando a ideia de que os benefícios da CBM superam os riscos. Uma criança não tem capacidade cognitiva para entender um procedimento tão complexo que altera a anatomia, fisiologia e o psicológico.

Por isto a importância do consentimento informado, da avaliação da capacidade de consentir, do empoderamento, da autonomia, que são elementos fundamentais para esclarecer o diagnóstico, o prognóstico, as formas de tratamento, os benefícios e riscos. Temas estes que os bioeticistas têm abordado nos ambientes que discutem as questões relacionadas aos avanços da ciência, mesmo sendo criticada por diversos estudiosos, como por exemplo, Steven Pinker que afirma explicitamente que a bioética impede o avanço científico, burocratizando e ameaçando a ciência com seus princípios obscuros e deslumbrantes, utilizando termos como dignidade, sagrado e justiça social. O autor afirma claramente que a bioética deve sair do caminho da ciência, pois semeia 0 pânico com suas especulações e frustra 0 desenvolvimento das pesquisas ${ }^{268}$.

Pinker ${ }^{258}$ afirma que pessoas morrem e estão morrendo de doenças que poderiam ser evitadas se não fossem os cientistas impedidos de desenvolvêlas ou se o processo fosse menos burocrático, quantas mortes prematuras poderiam ser evitadas, contudo a bioética interfere neste desenvolvimento. $O$ único caminho e objetivo moral que a bioética deveria seguir é sair do caminho da ciência ${ }^{258}$. Compartilhando o mesmo pensamento de Pinker, a psiquiatra 
Sally Satel diz que os bioeticistas não deveriam emitir opiniões sobre determinados assuntos, apenas mediar conflitos intrínsecos ao dilema ético, as opiniões dos bioeticistas não devem ser vistas como normas e não deve ter muito peso e considerações, afirma que Pinker e suas ideias representa uma "bomba" no campo da bioética ${ }^{259}$.

Klugman critica Pinker e Satel por tentarem neutralizar a bioética e afirma que a bioética está preocupada em proteger as pessoas, utilizando seus princípios e conceitos, os bioeticistas estudam questões éticas e morais das ciências da vida. Se a bioética "sair do caminho" será eliminado qualquer senso de reflexão sobre as pesquisas. A bioética oferece a oportunidade de pensar nas implicações das tecnologias sobre os seres humanos ${ }^{259}$.

A bioética tem como papel a análise ética da técnica a fim de inibir que, por exemplo, procedimentos e medicamentos sejam liberados no mercado sem que seja deczlarado a segurança de seu uso por humanos, sem que cause danos irreversíveis. A fala dos bioeticistas tem ganhando espaço nos meios de comunicação e disciplinas acadêmicas, e sendo procurados por agências governamentais, por pensadores e até mesmo pela mídia. A bioética não tem a intenção de dominar o mundo, mas de oferecer orientações sobre questões morais ${ }^{259}$.

Klugman ${ }^{259}$ relata que a bioética está mais preocupada com a tecnologia de ponta do que com o que é oferecido como alimento nas escolas. Infelizmente a bioética tem sido criticada por não abordar questões sociais importantes como alimentação e nutrição, ainda são poucos os trabalhos publicados na área da saúde pública, das mudanças climáticas, da pobreza, da educação das desigualdades na saúde, habitação e preços acessíveis aos produtos básicos. Solomon ${ }^{260}$ defende os bioeticistas afirmando que a bioética abraça a ciência, mas não de forma indiscriminada.

A impressão é que Pinker aceita que a os avanços da ciência aconteçam sem que haja interferência da bioética ou da população comum. Como no exemplo da criança que foi submetida à cirurgia bariátrica que parece a princípio um procedimento benéfico com o objetivo de emagrecimento. Contudo, mesmo sendo a obesidade responsável pelo desenvolvimento de 
comorbidades e tendo as opções de tratamentos limitadas, especialmente em crianças, muitos estudiosos recomendam esgotar todas as tentativas com tratamentos convencionais para diminuir o peso, como mudança alimentar, psicoeducação, tratamento medicamentoso e por fim a CBM.

Como afirmam Perryman e Sidoti mesmo o uso de medicamentos em crianças ainda é controverso, pois os efeitos colaterais envolvem sistemas cardiovascular e gastrointestinal, além da subnutrição. Sendo assim a realização da CBM em crianças envolve os mesmos riscos que em um adulto, porém o agravante é que a criança não tem poder de tomada de decisão, não tem capacidade de assimilar quão complexo é o procedimento, os riscos e benefícios associados e quais as complicações futuras de uma intervenção precoce $^{261}$. A CBM em adultos apresenta bons resultados, porém em crianças e adolescentes ainda é considerada polêmica. É necessário um consentimento informado cuidadoso ${ }^{262}$.

Os debates bioéticos têm construído uma ampla base de conhecimentos e conceitos oferecendo a possibilidade de resolver conflitos de interesses e valores que se apresentam na saúde pública, que englobam responsabilidades dos governos e cidadãos. As discussões em torno de temas polêmicos sempre existirão e todas as partes deverão ser ouvidas. No Brasil não é diferente, por isto, a bioética defendida por Garrafa ${ }^{263}$ é uma disciplina que exige um conhecimento complexo, tendo a característica de ser multi-intertransdisciplinar, buscando respostas para os problemas trazidos pelos novos progressos tecnológicos e biomédicos considerados situações emergentes, sem deixar de questionar os problemas persistentes.

É importante que questões relacionadas à CBM sejam colocadas em pauta, um exemplo clássico, são as seguradoras de plano de saúde que ainda tentam de todas as formas evitar a cobertura do procedimento de redução do estômago, eliminando em seus contratos cláusulas intituladas de cirurgias estéticas e CBM. Contudo, os tribunais têm obrigado os planos de saúde a arcar com os custos da cirurgia quando esta for o último recurso para reestabelecimento da saúde do segurado, considerando as cláusulas de exclusão abusivas. Os planos alegam ser a cirurgia um tratamento de 
emagrecimento, os tribunais alegam ser um tratamento de patologia grave com prescrição médica ${ }^{264-266}$.

Outro fator importante para o paciente submetido à CBM é a retirada do excesso de pele (dermolipectomia) decorrente do emagrecimento, os juízes justificam a obrigatoriedade da aceitação dos planos de saúde de realizar tal procedimento, pois faz parte do tratamento do obeso mórbido submetido à CBM e é necessário ao reestabelecimento da saúde e bem-estar do paciente 264,265. O Superior Tribunal de Justiça ${ }^{264}$ (STJ) afirma também que a recusa indevida dos planos em custear a cirurgia traz danos psicológicos, podendo o assegurado entrar com ação de dano moral. A Agência Nacional de Saúde (ANS) considera a gravidade da obesidade mórbida e acrescenta a CBM no rol de procedimentos que devem ser cobertos pelos planos de saúde por meio dos Anexos da Resolução Normativa (RN) $n^{\circ} 338^{267}$.

A judicialização em busca do procedimento de CBM não se restringe somente no âmbito privado, mas também no SUS que possui uma fila de espera em alguns hospitais que oferecem o procedimento. Porém, alguns pacientes entram com pedido de tutela antecipada para a realização da cirurgia alegando não poder esperar por muito tempo, tratando o caso como urgência, pois existem casos de risco de morte.

Alguns municípios têm recorrido das decisões favoráveis dos tribunais em relação ao paciente justificando que o custeio das despesas com 0 procedimento não são de suas responsabilidades e que caso acolhessem a decisão estariam lesando a economia local. O STJ entende que a gravidade e urgência da realização do procedimento em uma ou duas pessoas em um estado ou município são mais que justificáveis para a realização da cirurgia, pois compromete à saúde e a vida do paciente e que o prejuízo e dano iminente aos bens jurídicos podem ser protegidos por outros meios ${ }^{264,265}$.

A proteção deve ser constitucional e infraconstitucional para garantir os direitos de igualdade, dignidade, liberdade e inclusão social e respeito às diferenças corporais. Isto representa respeito à pluralidade defendida por $\operatorname{Arendt}^{268}$ (p.16) "A pluralidade é a condição da ação humana pelo fato de 
sermos todos os mesmos, isto é, humanos, sem que ninguém seja exatamente igual a qualquer pessoa que tenha existido, exista ou venha a existir".

As diferenças não devem ser motivos de exclusão e segregação social, por isto a construção de estratégias que eliminem as barreiras físicas, as barreiras sociais e principalmente a barreira psicológica do próprio individuo. Aaceitar as limitações do outro faz parte da construção social. Em muitos estados brasileiros os obesos ainda têm dificuldade de utilizar os meios de transportes públicos, isto é, falta acessibilidade. Muitos são obrigados a comprar duas passagens para poder utilizar duas poltronas, seja em aeronaves ou ônibus, pois as mesmas são estreitas. Com isto, o custo de uma viagem torna-se dispendiosa. A lei brasileira garante o direito de todos, inclusive do obeso, ter assentos exclusivos em todos os meios de transporte ${ }^{269,270}$.

Diante de todas as dificuldades enfrentadas pela pessoa obesa, nestes casos específicos de limitações físicas e sociais e de fatos concretos de discriminação e estigmatização, os julgadores da obesidade e da CBM, sejam eles, filósofos, pesquisadores, médicos, demais profissionais da saúde, planos de saúde e sociedade devem ponderar e proteger o direito da pessoa obesa de maneira a preservar e fazer com que prevaleça o seu bem-estar e sua dignidade, evitando assim qualquer tratamento humilhante do ser humano de forma universal. A CBM pode ser considerada um procedimento de reabilitação, pois um dos objetivos é fazer com que o indivíduo retome suas atividades cotidianas, sociais e laborativas.

A DUBDH aborda a dignidade humana, o direito a vida, a qualidade de vida, a não-discriminação e não-estigmatização de forma distinta como direitos absolutos na prática, assim como os direitos humanos que são fundamentais e positivados, de modo que o resultado de um julgamento deve obrigatoriamente passar por um processo de ponderação e que nenhum direito fundamental seja sobreposto ou mais importante que o outro, pois são interdependentes em sua essência. 


\section{OBJETIVOS}

\subsection{Geral}

Analisar a Cirurgia Bariátrica e Metabólica sob uma visão bioética como um procedimento capaz de interferir nas dimensões corporais e sociais, tendo como referência de estudo os princípios bioéticos do "Benefício e Dano" e "Não-Discriminação e Não-Estigmatização" listados na Declaração Universal sobre Bioética e Direitos Humanos da Unesco (artigos 4 e 11 respectivamente) e relatos de gastroplastizados.

\subsection{Específicos}

- Mostrar que a CBM integra o estudo da corporeidade enquanto procedimento que modifica a imagem corporal e a percepção social em relação aos corpos resgatando a dignidade e qualidade de vida do indivíduo.

- Despertar discussões sobre os princípios do "Benefício e Dano" e "Nãodiscriminação e Não-estigmatização" da Declaração Universal sobre Bioética e Direitos Humanos da Unesco (DUBDH) em torno do procedimento CBM mostrando que a DUBDH é uma ferramenta de auxílio educacional e institucional para resolver conflitos - discriminação e estigmatização - em torno da pessoa obesa.

- Descrever por meio de relatos de gastroplastizados a experimentação da discriminação e estigmatização em relação à imagem corporal obesa. 


\section{PERCURSO METODOLÓGICO}

O estudo se justifica por ser a obesidade uma doença global que afeta não somente a saúde e a imagem corporal do indivíduo, mas compromete a economia de uma sociedade devido o aumento de mortes em consequência das doenças correlacionadas e do alto custo com o tratamento destas, principalmente da obesidade mórbida.

As condições para a execução desta pesquisa foram favoráveis, pois existem materiais teóricos sobre o tema CBM e correlatos disponíveis, abordados em meios eletrônicos e impressos, destacando que os materiais disponíveis são bastante específicos, sendo raros os relatos na literatura nacional e internacional de estudos que relacionem conjuntamente a Bioética, a CBM e Obesidade mórbida, em especial os princípios do Benefício e Dano e Não-discriminação e Não-estigmatização. A liberdade para a coleta de informações para a pesquisa também viabilizou sua realização, com isto os objetivos possivelmente foram atingidos.

\subsection{Tipo de Pesquisa}

Trata-se de uma pesquisa com abordagem quanti-qualitativa por ser a metodologia que melhor respondeu a este desafio por tentar aprofundar-se em uma realidade específica no intuito de analisar o problema, perspectivas e possíveis soluções que vão além dos limites da anatomia humana, não se preocupando apenas com determinismos estatísticos e epidemiológicos presentes nas pesquisas quantitativas.

A abordagem humanística, entendida como qualitativa, teve maior destaque pela tentativa de compreensão, análise e interpretação do conteúdo emitido pela população estudada que teve caráter subjetivo, contudo houve dados quantificáveis, pois é praticamente impossível não citar números quando se aborda uma determinada doença, suas causas e consequências.

Como afirma Minayo ${ }^{271}$, dados qualitativos e quantitativos não estão em oposição, pelo contrário, entre eles há uma condição complementar, que, quando bem trabalhadas a teórica e a pratica, produzem riqueza de 
informações, aprofundamento e maior fidedignidade interpretativa. Os dados quantificáveis deste estudo são explicitados por dados numéricos, tabelas e quadros com a intenção de validade interna do material de forma a garantir o mínimo necessário para que o experimento seja validado na instância específica onde foi realizado.

Os dados qualitativos neste caso foram de caráter descritivos, por abordar aspectos subjetivos, motivações não explícitas, de forma espontânea, considerando que há uma relação dinâmica entre o mundo real e o sujeito, isto é, há um vínculo indissociável entre o mundo objetivo e a subjetividade do sujeito, e que não pode ser traduzido em números ${ }^{271}$. A intenção foi compreender o problema a partir da visão, vivência, aflições, desejos, anseios e sentimentos, e para que isto acontecesse era necessária a presença de sentimentos de aceitação e a confiança entre pesquisador e participantes.

\subsection{Fonte Primária e Fontes Secundárias de Dados}

As fontes de informações do estudo são consideradas primárias, uma vez que as soluções das possíveis indagações somente puderam ser obtidas junto ao público alvo.

Todo o material utilizado como fontes secundárias incluído na pesquisa, necessariamente apresentavam em seus contextos as palavras-chaves que envolvia o tema. As seguintes palavras-chaves foram utilizadas individualmente ou em associação: Corporeidade, Obesidade Mórbida, Cirurgia Bariátrica e Metabólica, Bioética, Declaração Universal Sobre Bioética e Direitos Humanos, Benefício, Dano, Não-Discriminação, Não-Estigmatização, Educação. A princípio, a data do ano de publicação dos textos analisados não foram definidas enquanto avaliação histórica, contudo os dados epidemiológicos foram priorizados nos documentos produzidos nos últimos cinco anos.

O cuidado maior em todas as etapas foi analisar e avaliar o contexto e a fonte no qual foi produzido o documento. Foram selecionados livros, artigos, leis, monografias, teses, jornais, revistas de forma impressa e eletrônica e 
documentários, sendo utilizadas fontes como: SciELO - Scientific Electronic Library Online, Banco de Dados Agregados do IBGE, Biblioteca Digital Mundial Unesco, Biblioteca Nacional Digital /Fundação Biblioteca Nacional, Portal de Periódicos da Capes, Portal de Pesquisa da BVS - Biblioteca Virtual em Saúde: LILACS, IBECS, MEDLINE, PubMed, Revistas especializadas, sites oficiais do Governo Brasileiro e internacionais e de entidades não-governamentais e profissionais que continham e disponibilizassem informações sobre o tema proposto como leis, resoluções e outros.

\subsection{Local de Realização da Pesquisa de Campo}

O local escolhido para realização da pesquisa foi o Hospital Regional de Taguatinga (HRT) situado na cidade de Taguatinga - região administrativa do Distrito Federal - hospital público participante do SUS dirigido pela Secretaria de Estado de Saúde do Distrito Federal (SES/DF) uma instituição de nível terciário. É um hospital escola e permite a realização de pesquisas deste que autorizadas pelo Comitê de Ética e Pesquisa da própria Secretaria de Saúde do Distrito Federal sendo a Fundação de Ensino e Pesquisa em Ciências da Saúde (FEPECS) coparticipante. Local escolhido pela pesquisadora por conveniência já que a mesma é Enfermeira da SESDF. Neste caso, não houve indicação de uma unidade interna específica dentro do hospital para a escolha dos participantes porque os possíveis participantes estavam distribuídos ou lotados em diferentes unidades do hospital como, por exemplo: emergência, cardiologia, acolhimento, centro obstétrico, maternidade, centro cirúrgico e ambulatório.

\subsection{Universo, Perfil dos Participantes e Abordagem}

De acordo com Schiffman e Kanuk ${ }^{272}$ a amostragem deve conter três itens fundamentais: definir quem é o objeto da pesquisa (unidade da amostra), quantos objetos serão estudados (tamanho da amostra) e como serão selecionados (método aplicado). Quanto maior o número de elementos amostrais estudados, maior é a probabilidade de que novas amostras tomadas do mesmo universo amostral expressem as mesmas conclusões. 
Partindo da ideia de maior amostragem maior probabilidade de acertos, optou-se por entrevistar toda a população alvo, isto é, o universo, composto por 25 participantes, pela possibilidade de localização destes. Este tipo de abordagem tem como grande vantagem a exatidão das respostas, $100 \%$ de partipação. Isto acontece porque a margem de erro é teoricamente zero, visto que todas as pessoas são entrevistadas. A pesquisa por população é indicada para as pesquisas em que é possível conversar com todos os entrevistados.

Por ser um número pequeno de indivíduos a coleta dos dados foi rápida e atendeu a proposta do estudo, todos possuíam as mesmas características básicas segundo os critérios de inclusão, isto significou maior grau de homogeneidade e o nível de confiança do estudo porque todos os elementos entraram no foco da investigação.

A população era formada por servidores gastroplastizados do HRT. O status de servidor não teve caráter discriminatório na pesquisa, apenas serviu de ponto facilitador para a escolha e possibilidade de encontrar gastroplastizados em um número considerável, em um mesmo espaço físico, minimizando assim o tempo gasto na procura dos participantes. Contudo por ser profissionais de saúde a avaliação das respostas exigiu um esforço maior no sentido de que a princípio estes possuíam conhecimento sobre o tema abordado e que incorporam informações do cotidiano e da própria experiência, o que os diferenciam das pessoas comuns, isto é, que atuam em outras áreas do conhecimento que não da área da saúde. Todos foram convidados a participar, tendo as mesmas oportunidades de participação. A aceitação foi de $100 \%$.

Critérios de Inclusão: A pesquisa foi direcionada aos indivíduos maiores de 18 anos (servidores do HRT) gastroplastizados que adotaram qualquer método de gastroplastia, e que tinham realizado a cirurgia há mais de um ano (período razoável para detectar mudanças reais na vida cotidiana). Critérios de Exclusão: Estão excluídos todos que não possuem os requisitos dos critérios de inclusão.

Os participantes da pesquisa pertenciam a diversas categorias profissionais, portanto: médicos, enfermeiros, técnicos em enfermagem, 
farmacêuticos, nutricionistas e técnicos de laboratório. Foram entrevistados individualmente nas dependências da unidade, cada participante foi indicado pela letra $A$ seguido de um número ordinal sequencial (A1 ,A2, A3...A25) para facilitar o ordenamento dos dados e preservar a identidade do indivíduo. $\mathrm{Na}$ unidade, a pesquisadora abordou os participantes em momentos de pouco movimento e atividades (evitando assim a interrupção da entrevista por situações adversas) e permitindo um livre fluxo de ideias.

Inicialmente ocorreu a apresentação da pesquisadora, em seguida a explicação do porquê de sua presença no local e logo após foi feito o convite para que o participante participasse da pesquisa. Cada indivíduo foi convidado a participar, e previamente esclarecido dos objetivos, métodos, benefícios e riscos; e após leitura, esclarecimentos e aceitação era entregue para anuência o Termo de Consentimento e Livre Esclarecimento (TCLE) ficando com uma cópia. (Apêndice A).

\subsection{Instrumento para Coleta de Dados e Aplicação}

$O$ instrumento escolhido para coleta de dados desta pesquisa foi 0 questionário (Apêndice B) que segundo Gil ${ }^{273}$ :

(...) é uma técnica de investigação composta por um número mais ou menos elevado de questões apresentadas por escrito às pessoas, tendo por objetivo o conhecimento de opiniões, crenças, sentimentos, interesses, expectativas e situações vivenciadas (...).

O questionário de autopreenchimento foi elaborado contendo 34 perguntas em formato Aberta, Fechada e Semi-aberta. As perguntas abertas tiveram a intenção de dar liberdade de expressão/sentimentos aos participantes. As questões fechadas de caráter bipolar foram definidas para questões de fatos reais, problemas pontuais e opiniões cristalizadas. As perguntas semi-abertas permitiram optar por uma das escolhas e abriu espaço para expor opiniões, experiências, pensamentos sobre a opção escolhida.

O instrumento apresentava quatro dimensões partindo de um contexto geral até chegar a um contexto mais específico: (1) Perfil sócio-demográfico; (2) Histórico físico, de saúde-doença, social e familiar antes da realização da 
CBM incluindo a relação do indivíduo com seu corpo e a imagem corporal, da relação com a sociedade e sobre os temas discriminação e estigmatização (3) As mudanças pessoais e sociais após o procedimento; e (4) Abordagem ética no processo do tratamento e sobre satisfação ou insatisfação em relação ao procedimento. Sempre buscando identificar aspectos referentes às percepções do ser obeso e do ser magro, dos preconceitos e relacionar o antes e o depois da CBM.

\subsection{Aspectos Éticos da Pesquisa}

O projeto foi submetido ao Comitê de Ética e Pesquisa da Faculdade de Ciências da Saúde da Universidade de Brasília e também ao Comitê de Ética e Pesquisa da Secretaria de Estado de Saúde do Distrito Federal como Coparticiante. $O$ processo (trabalho de campo) teve início após análise e aprovação do Projeto pelos Comitês de Ética em Pesquisa, aprovado sob o número CAAE: 23680113.3.3001.5553. As entrevistas foram realizadas entre os meses de Novembro e Dezembro de 2015.

Os aspectos éticos da pesquisa foram respeitados por envolver seres humanos: autonomia, não maleficência, justiça, beneficência e equidade. A pesquisa cumpriu as orientações da nova Resolução CNS 466, de 12 de dezembro de $2012^{274}$ que dispõe sobre as diretrizes e normas regulamentadoras de pesquisas envolvendo seres humanos. $O$ instrumento utilizado para coleta de dados possuía perguntas que se referiam aos aspectos da vida íntima dos participantes, por este motivo o respeito ao sigilo e a privacidade das informações foram eticamente analisados e guardados sob responsabilidade do pesquisador, evitando assim qualquer constrangimento.

A precaução de algum possível risco, de ordem não-física (emocional, moral, social ou espiritual), mesmo que a probabilidade fosse ainda muito pequena, foi levada em consideração, pois, em se tratando de um tema que envolve a obesidade e a CBM em que a discriminação e estigmatização fez ou ainda faz parte das vidas dos ex-obesos é necessário o cuidado com as palavras utilizadas, com as perguntas apresentadas, e também uma exigência dos comitês de ética. Por isto foi disponibilizado a assinatura por meio de rubrica (opcional) e aqueles que se identificaram nominalmente por extenso, 
ainda assim seus nomes não foram divulgados, nos resultados apresentados em nenhum momento se faz referência a nome ou qualquer características dos participantes, preservando assim sua integridade moral e psíquica.

Os possíveis riscos diretos na esfera moral, social, psicológica ou espiritual não poderiam ser previamente e totalmente excluídos, porém a pesquisadora teve o cuidado de seguir o princípio da não-maleficência, tendo a obrigação de não infligir danos ou males intencional, ou desconforto, constrangimentos, pois foi levado em consideração a natureza psicológica e social do participante como ser humano respeitando seus valores, cultura, crenças e emoções.

Os riscos indiretos estariam ligados à exposição dos dados no texto final, contudo os dados foram transcritos e discutidos de forma ética apenas com finalidade acadêmica. Este estudo teve como motivação mostrar que existe discriminação e estigmatização contra a pessoa com obesidade mórbida e que a bioética por meio dos bioeticitas e da Declaração Universal Sobre Bioética e Direitos Humanos da Unesco (DUBDH) pode auxiliar a inibir estes atos maléficos por meio da divulgação de seus princípios, neste caso, especificamente o artigo 11 que aborda a Não-Discriminação e NãoEstigmatização. E em relação ao tema CBM o estudo pretendeu mostrar que a bioética tem a intenção de zelar pela vida humana evitando procedimentos desnecessários e quando necessários deve seguir o princípio do artigo 4 da DUBDH que aborda o os princípios do Benefício e Dano.

\subsection{Ressarcimento ou Indenizações por Danos}

Os participantes da pesquisa foram respeitados em valores culturais, sociais, morais, étnicos, religiosos, éticos, entre outros. Caso algum participante se sentisse agredido ou ofendido em sua moral, cultura, crença, dignidade, intimidado, vergonha, humilhado, com medo, discriminado ou exposto teria o direito de reivindicar seus direitos legais conforme legislação vigente Resolução do Conselho Nacional de Saúde (CNS) 466/2012 e demais que achasse necessário. A pesquisadora se comprometeu a ressarcir 
eventuais despesas com tratamentos psicológicos e outros, desde que o dano comprovadamente tenha sido ocasionado pela pesquisa ou pesquisadora.

\subsection{Ordenamento e Técnica de Análise dos Dados}

À medida que os questionários foram sendo preenchidos e entregues, as informações relativas ao objeto de estudo foram levantadas e organizadas para comprovar ou não a consistência dos objetivos. O conteúdo das informações prestadas pelos sujeitos da pesquisa foram analisados previamente $\mathrm{e}$ posteriormente classificados (com exceção das perguntas abertas que foram transcritas). A tabulação dos dados quantitativos foi realizada manualmente, por se tratar de uma amostra populacional pequena, utilizando a técnica do Traço-e-Risco que segundo Lakatos e Marconi ${ }^{275}$ (p.145) é:

O mais fácil dos procedimentos consiste em traçar uma linha convencional, de fácil conjunto, em relação a cada caso compreendido na série que se conta. Realiza-se o traço-erisco mediante a elaboração de um quadro de frequência: à esquerda colocando-se os números das categorias ou grupos e ao lado deles vão-se anotando os dados, por meio de riscos.

Os resultados foram representados por meio de tabelas criadas pela ferramenta Word ${ }^{\circledR}$ e Exce $^{\circledR}$ do programa Microsoft Office acompanhados das análises e discussões. A análise dos dados qualitativos foi feito por meio de leitura crítica, identificando os pontos que mereciam maior atenção no sentido de confirmar os objetivos do estudo. Os dados quantitativos obtidos a partir da tabulação dos questionários foram expostos e analisados conforme a disposição dos mesmos de acordo com o questionário.

A técnica escolhida foi a Análise Discurso referindo-se a linha francesa proposta por Michel Pêcheux ${ }^{276}$, por se enquadrar melhor no processo e nos objetivos propostos, pois explora a relação entre o discurso e a realidade. $O$ discurso analisado foram as falas dos participantes da pesquisa. Como Pêcheux afirmava que a linguagem utilizada nos discursos não se restringe apenas as regras formais, mas que o simbólico deve ser associado para que seja possível interpretar na prática o que está sendo dito. Pois todo discurso deve ser analisado no caráter linguístico, histórico e social, e não somente político. 
Como Orlandi ${ }^{277}$ defendia que o discurso está sempre em movimento, é dinâmico o que representa a prática da linguagem, é o homem falando. Aquele que fala traz em seu discurso representações individuais sobre si, sobre o outro e sobre o tema abordado. É necessário decodificar o que está sendo falado e também o que não está visível na fala do indivíduo, perpassando assim, pelo biopsicopolíticosocial. Para interpretar o discurso é preciso conhecer o sujeito e o tema em discursão.

A partir dos discursos dos participantes sobre às experiências vividas relação à obesidade, a imagem corporal e a CBM será possível observar seus efeitos e sentidos. A materialidade da linguagem está inserida na história de vida de forma individual e coletiva, a análise do discurso permite entender a construção da identidade a partir das ideologias e a adoção de uma imagem corporal pela adoção dos discursos das mídias e da sociedade que exige uma padronização corporal .

Por meio da análise do discurso é possível analisar os inúmeros discursos das mídias e sociedade sobre alimentação, obesidade, modelagem corporal. Assim como Foucault ${ }^{278}$ defendia que os discursos se articulam com práticas não discursivas, nada mais é que uma estratégia para impor vontades, moldar identidades, pulverizar valores ditos como verdades do que é ser normal, isto significa a existência de micropoderes. As propagandas são verdadeiros discursos que orientam na criação de identidades que representam um comando disciplinador.

Isto mostra a face multidisciplinar do tema, uma vez que para a análise do discurso é necessária à intervenção sociológica, filosófica, psicológica e de outras ciências humanas para tentar interpretar os elementos sociais, mentais e sentimentais envolvidos, tentar entender se o indivíduo é formado a partir das ideias sociais, sendo então um indivíduo passivo diante do pensar coletivo. $O$ discurso do sujeito pode revelar detalhes das crenças, dos valores, dos pensamentos e opiniões sobre o tema que estão internalizados, é isto que caracteriza e preserva o perfil qualitativo do estudo. Observar às expressões mais utilizadas, as ideias centrais, as semelhanças de sentido e posicionamentos. 
Os resultados desde estudo estão limitados à população pesquisada, a generalização das respostas do estudo apresentado não garante que esse efeito idêntico a outro lugar e grupos, senão o grupo o analisado, podendo a repetição obter resultados semelhantes. As argumentações e criticas foram realizadas com o cuidado de assegurar que as etapas da pesquisa de campo fossem cumpridas e a construção textual vinculada ao contexto e história. 


\section{RESULTADOS E DISCUSSÕES}

Os dados apresentados são resultados de pesquisa de campo projetada para levantar informações sobre o tema "Uma Análise da Cirurgia Bariátrica a luz da Declaração Universal Sobre Bioética e Direitos Humanos: NãoDiscriminação e Não-Estigmatização da Pessoa com Obesidade Mórbida" alguns dados são demonstrados por meio de tabelas por possibilitar uma compreensão imediata do fenômeno pelo leitor e um conhecimento da situação real e atual da questão estudada, os resultados são apresentados em porcentagens absolutas que significa 100\% da população, conforme Tabela 4.

No instrumento utilizado - questionário - a idade foi codificada por faixas etárias que abrangem entre 18 anos e 51 anos ou mais, contemplando assim quase todas as faixas etárias permitidas pela legislação vigente, exceto crianças e adolescentes que não estavam nos critérios de inclusão. A idade entre 36 e 40 anos prevaleceu entre os participantes da pesquisa correspondendo a $28 \%$.

Em relação ao sexo (entendido neste estudo como sendo características sexuais do sistema reprodutivo anatômico, não entrando no mérito do gênero baseado na consciência interna, isto é, na identidade de gênero) isto não representa um fator de discriminador, mas apenas para melhor entendimento dos dados. Destacando que os transgêneros também são vítimas do estigma e discriminação. Dos participantes da pesquisa $64 \%$ eram mulheres. O sexo foi abordado por ser uma informação importante no que se refere ao comportamento dos indivíduos e a relação com a obesidade em todos os graus e riscos acrescidos a doenças correlacionadas como hipertensão, diabetes, depressão, baixa estima, disfunção sexual; entre outros.

Pois, segundo Zárate, Acevedo e Garcia ${ }^{279}$ quando se fala em obesidade entre os sexos (homem e mulher), as consequências fisiológicas são quase sempre semelhantes, porém o psicológico feminino é consideravelmente mais afetado por comprometer a estética, pois a cultura 
global impõe a beleza e a magreza como parâmetros para determinar a inclusão ou exclusão em diversos segmentos da sociedade.

A raça ou cor não foram abordadas porque a obesidade mórbida atinge pessoas de todas as classes sociais e diferentes idades. Contudo os aspectos sociais e comportamentais devem ser considerados de acordo com a cultura. Quanto mais vulnerável o indivíduo, maior a pressão social, o racismo, menor escolaridade, menor renda, maior risco de adoecimento por doenças infectocontagiosas e DCNT. Existem doenças mais prevalentes em negros e brancos, contudo a ocorrência da obesidade em diversas raças pode ter como consequências a falta de informação, de acesso aos serviços de saúde, fatores genéticos, qualidade da alimentação. Por fim, trata-se de uma doença universal e democrática que atinge todas as etnias. 
Tabela 4 . Dados sócio-demográficos: idade, gênero, religião, estado civil, escolaridade, renda familiar e categoria profissional.

\begin{tabular}{|c|c|c|c|c|c|c|c|c|c|c|c|c|c|c|c|c|c|}
\hline $\begin{array}{l}\text { Idade } \\
\text { (anos) }\end{array}$ & no/Sexo & $\%$ & Religião & no & $\%$ & $\begin{array}{l}\text { Estado } \\
\text { civil }\end{array}$ & no & $\%$ & Escolaridade & $\mathrm{n}^{\circ}$ & $\%$ & $\begin{array}{l}\text { Renda } \\
\text { Familiar } \\
\text { * Salário } \\
\text { Mínimo }\end{array}$ & no & $\%$ & $\begin{array}{l}\text { Categoria } \\
\text { Profissional }\end{array}$ & no & $\%$ \\
\hline $18-25$ & $\begin{array}{l}\text { Total }=02 \\
{ }^{*} \mathrm{~F}=01 \\
{ }^{*} \mathrm{M}=01\end{array}$ & 08 & Católico & 08 & 32 & Solteiro & 05 & 20 & $\begin{array}{l}\text { Ens. Méd. } \\
\text { Completo }\end{array}$ & 08 & 32 & $4-6$ & 15 & 60 & Médico & 06 & 24 \\
\hline $26-30$ & $\begin{array}{l}\text { Total }=04 \\
{ }^{*} \mathrm{~F}=01 \\
{ }^{*} \mathrm{M}=03\end{array}$ & 16 & Protestante & 12 & 48 & Casado & 11 & 44 & $\begin{array}{l}\text { Superior } \\
\text { Completo }\end{array}$ & 17 & 68 & $7-9$ & 10 & 40 & Enfermeiro & 03 & 12 \\
\hline $31-35$ & $\begin{array}{l}\text { Total }=03 \\
{ }^{*} \mathrm{~F}=01 \\
{ }^{*} \mathrm{M}=02\end{array}$ & 12 & Espírita & 03 & 12 & Viúvo & 02 & 08 & & & & & & & $\begin{array}{l}\text { Técnico de } \\
\text { Laboratório }\end{array}$ & 02 & 8 \\
\hline $36-40$ & $\begin{array}{l}\text { Total }=07 \\
{ }^{*} \mathrm{~F}=04 \\
{ }^{*} \mathrm{M}=03\end{array}$ & 28 & $\begin{array}{l}\text { Não } \\
\text { Informado }\end{array}$ & 02 & 08 & $\begin{array}{l}\text { União } \\
\text { Estável }\end{array}$ & 06 & 24 & & & & & & & $\begin{array}{l}\text { Técnico de } \\
\text { Enfermagem }\end{array}$ & 14 & 56 \\
\hline $41-45$ & $\begin{array}{l}\text { Total }=03 \\
{ }^{*} \mathrm{~F}=03\end{array}$ & 12 & & & & Divorciado & 01 & 04 & & & & & & & & & \\
\hline $46-50$ & $\begin{array}{l}\text { Total }=03 \\
{ }^{\star} \mathrm{F}=03\end{array}$ & 12 & & & & & & & & & & & & & & & \\
\hline$\geq 51$ & $\begin{array}{l}\text { Total }=03 \\
{ }^{*} \mathrm{~F}=03\end{array}$ & 12 & & & & & & & & & & & & & & & \\
\hline $\begin{array}{l}\text { Total } \\
\text { Absoluto }\end{array}$ & $\begin{array}{l}\text { Total }=25 \\
{ }^{*} \mathrm{~F}=16 \\
{ }^{*} \mathrm{M}=09\end{array}$ & 100 & & 25 & 100 & & 25 & 100 & & 25 & 100 & & 25 & 100 & & 25 & 100 \\
\hline
\end{tabular}

Fonte: Dados da pesquisa, 2016. Lengenda: *M (Masculino), ${ }^{\star} \mathrm{F}$ (Feminino). 
Os resultados desta pesquisa mostram que $48 \%$ se apresentam como protestantes seguidos por $8 \%$ de católicos. A religião foi abordada como um dado curioso e de importância aceitável já que algumas pesquisas demonstram uma associação entre a obesidade e religião. Segundo Feinstein ${ }^{280}$ que realizou um estudo nos EUA no ano 2010 no qual foram entrevistados 2.433 sujeitos jovens (homens e mulheres) que faziam parte de uma pesquisa de "Desenvolvimento de Risco em Artérias Coronárias em Jovens Adultos" e foram seguidos por 18 anos. A participação religiosa variava de alta (uma vez por semana ou mais), média (regular, mas não semanais), baixa (raramente) e nenhuma.

Os resultados demonstraram que pessoas que vão à igreja com frequência (pelo menos uma vez por semana) têm maior probabilidade de até $50 \%$ de se tornarem obesas na meia-idade com IMC maior ou igual a 30 . As hipóteses apresentadas são de que as religiões em sua maioria estão sempre rodeadas por festividades que envolvam alimentos, e a associação da fé com a felicidade e satisfação pessoal também são fatores que estimulam o consumo de alimentos, pessoas felizes comem maior quantidade ${ }^{280}$. A pesquisa deixa claro que o fato de ir a igreja não representa ter a saúde pior ou melhor, apenas existe a chance de se tornarem obesas.

Outros estudos associam o aumento da longevidade e a diminuição da mortalidade com a prática religiosa por estimular o não uso de drogas lícitas e ilícitas como, por exemplo, o fumo, o álcool, combater o pecado da gula, entre outros $^{280}$. Daí um importante papel da religião em promover a conscientização de seus seguidores no sentido de estimular a alimentação e um comportamento saudável. Algumas instituições religiosas já estão conscientes dos riscos da obesidade e trabalham na tentativa de diminuir o IMC elevado de seus membros, estimulando a mudança de comportamento e hábitos.

O estado civil também é um dado importante para definir o psicológico, a rotina, a repercussão da obesidade mórbida nas relações familiares, profissionais e principalmente na vida sexual, pois as doenças não derivam apenas de microrganismos e fatores hereditários. Os participantes em sua maioria são casados (44\%) seguidos dos que mantém união estável (24\%) e os 
solteiros, viúvos e divorciados correspondem juntos a $32 \%$ indicando uma preocupação com o corpo e a manutenção das relações sociais e principalmente na vida amorosa.

Em relação à escolaridade $68 \%$ possui curso superior, o que indica maior acesso à saúde e às informações sobre cuidados com o corpo e as possibilidades de controle das doenças. O que confirma uma pesquisa realizada pela Organização para a Cooperação e Desenvolvimento Econômico ${ }^{281}$ (OCDE) em 2013, que a educação traz benefícios significativos para o individual e o coletivo, traz oportunidades de emprego e renda, status social e aumento do tempo de vida por ser fundamental para a formação moral dos indivíduos e do bem-estar, pois ajuda a melhorar e promover à saúde, a cidadania e conter a violência contra a sociedade e indivíduos.

A atividade profissional como uma relação social também foi levada em consideração, pois a ausência desta pode afetar a saúde do indivíduo. $O$ trabalho e a renda são dados que demonstram a participação ativa do indivíduo na sociedade, traz dignidade e valorização do ser humano, além do exercício da cidadania. $O$ poder aquisitivo é importante por levar em consideração o poder de compra e acesso de bens, serviços e tratamentos em saúde, sejam medicamentos inibidores de apetite, alimentos denominados diet e light e tratamentos mais avançados como a CBM. A categoria profissional com maior número de gastroplastizados no grupo pesquisado correspondendo a $56 \%$ são Técnicos em Enfermagem seguidos por 24\% de Médicos.

A classe social e o local de residência não foram abordados, pois quando se fala em obesidade mórbida estes dados são irrelevantes. Atualmente esta doença atinge todas as camadas sociais, seja por hereditariedade, má nutrição por padrões alimentares inadequados, sedentarismo, problemas psicológicos, doenças metabólicas, o acesso a "fastfood" e alimentos industrializados estão disponíveis em quantidade, qualidade e valores que permitem o acesso a qualquer indivíduo.

As questões 2,3 e 4 do questionário estão relacionadas com 0 aparecimento e desenvolvimento da obesidade na vida do participante, se a doença estava presente desde a infância, e se o consumo alimentar era em 
quantidade excessiva, se havia obesos na família, por serem estas algumas das causas da obesidade. Os dados da pesquisa mostram que $70 \%$ dos participantes alegaram ser obesos desde a infância e os 30\% restante desenvolveram a doença ao longo da vida. Em relação ao consumo 44\% assumiram que comiam em excesso e $40 \%$ que comiam muito, conforme pode ser observado na Tabela 5.

Tabela 5. Percepção da quantidade de alimentos ingeridos antes do procedimento.

\begin{tabular}{llc}
\hline Alimentação & $\mathrm{n}^{-}$ & $\%$ \\
\hline Em excesso & 11 & 44 \\
Muito & 10 & 40 \\
Normal & 04 & 16 \\
Pouco & 00 & 00 \\
Total Absoluto & 25 & 100 \\
\hline
\end{tabular}

Fonte: Dados da pesquisa, 2016.

A obesidade mórbida e a compulsão alimentar estão associadas em muitos casos, juntamente com conjuntos de fatores e complicadores que pode ser genético, distúrbios psiquiátricos, bioquímicos, estilo de vida e outros. Quando questionados se existiam obesos na família 70\% afirmaram que existiam obesos e $30 \%$ responderam que não. Esta questão teve a intenção de relacionar a obesidade como uma doença contagiosa, isto é, pode ser possível adquirir a obesidade por adoção de comportamentos e hábitos dos pais ou parentes próximos.

Estes resultados demonstram que o comportamento dos pais, familiares mais próximos, cônjuges, amigos do trabalho influenciam no comportamento dos filhos na maioria dos casos. Para Coob et a ${ }^{282}$ existe risco de incidência da obesidade em cônjuges, quando um dos cônjuges se torna ou se mantem obeso o risco do outro se tornar obeso quase que duplica, por isto deve-se planejar intervenções de prevenção da obesidade em casais. 
Segundo Hruschka et $a f^{283}$ a obesidade é socialmente contagiosa. $O$ despreparo de mães que abandonam a amamentação e trocam o leite materno por fórmulas preparadas com leite artificial, diminuição da atividade física, difusão de jogos eletrônicos. A industrialização e a agricultura desenvolveram tecnologias que permitiram melhorias incalculáveis nestas áreas, porém os malefícios também acompanham às novas tecnologias como a expansão de alimentos com baixo valor nutritivo. Para Barros Filho ${ }^{284}$ os fatores ambientais influenciam no aumento de peso, dificilmente um filho conseguirá ser magro com pais obesos, as famílias devem procurar modificar o ambiente e fatores que estimulam a obesidade.

A obesidade de acordo com Segatto ${ }^{284}$ e Barros Filho ${ }^{285}$ tem histórico familiar por traços genéticos ou estilo de vida sedentário. Alimentos calóricos como guloseimas fazem parte das mesas dos brasileiros e muitas vezes substituem o almoço e jantar. A obesidade é construída dentro de casa, as teorias ambientalistas confirmam que os hábitos atuais da nova sociedade refletem e contribuem para o crescimento da obesidade e doenças associadas, principalmente a obesidade infantil.

Daí o papel da mãe como auxiliadora na eliminação da obesidade, pois ela é quem deveria determinar em sua maioria o que se come dentro de casa. As crianças estão subordinadas às condições familiares e sofrem influência dos pais, são fatores que predispõe à obesidade familiar denominada por Jahnke e Warschburger ${ }^{286}$ como família obesogênica. Segundo Camargo et $a^{287}$ se a mãe muda seus hábitos alimentares há uma maior chance dos filhos e de toda família reduzir o peso e mudar o comportamento alimentar, mudando assim o estado nutricional familiar.

A questão de número 5 teve interesse em saber quais as principais dificuldades enfrentadas na vida cotidiana dos participantes em consequência da obesidade mórbida, pois a discriminação em torno do obeso acontece em sua maioria de forma velada. As desigualdades em relação às pessoas obesas e não obesas se tornam cada vez maior, isto é, ações que permitem a restrição da vida social, o desemprego e a acessibilidade dificultados em ambientes públicos e privados reforçam cada vez mais a discriminação e o estigma. Estes 
fatores contribuem para o aumento da morbi-mortalidade, tendo como consequência a morte precoce. A seguir a transcrição dos relatos dos participantes:

$\boldsymbol{A 1}$ - "As pessoas obesas são esquecidas, em Brasília mesmo, as ruas são desniveladas, as catracas dos ônibus são estreitas, as cadeiras em todos os lugares são pequenas, os semáforos são rápidos para fechar e abrir, a pessoa obesa como eu era, não pode correr, ela não tem agilidade."

A2 - "As filas dos bancos tem preferencial para idoso, deficiente físico, mulher com bebê de colo, mas para obeso não tem. Na faculdade em que estudo as cadeiras são estreitas, os banheiros são pequenos e não tem vaga de estacionamento reservado para obeso. Eu sofri muito com isto. A faculdade é um ambiente teoricamente de pessoas inteligentes, sociáveis e conhecedoras e respeitadoras dos direitos dos outros. Mas nada acontece. Quem sabe um dia isto vai se tornar realidade".

A3 - "Tive um amigo que morreu em decorrência da obesidade, os hospitais não estão preparados para nós receber, até na hora da morte passamos vexame, não tem urna apropriada e nem cova."

A4 - "O gordo é visto como um bufão, isto é ridículo. Somos tratados com desdém, é uma dificuldade para encontrar roupas e sapatos com numeração grande. Cadeira do cinema é uma tortura, tenho a impressão que é de propósito para desestimular os gordos de frequentar estes lugares."

A5 -"Os hospitais não estão adaptados para pessoas obesas, as macas e camas são estreitas, as cadeiras de roda não acomodam e não suportam o peso dos obesos. Os aparelhos de pressão não cabem nos nossos braços, eu sempre tinha problema com isto quando precisava me internar. Tenho certeza que outras pessoas também sofrem."

A6 - "Sofro demais a procura de roupas, existe um tal de tamanho único, até parece que todas as pessoas vestem o mesmo número."

A7 - Ter que morar em prédio sem elevador.

A8 - "Até para morrer o obeso é discriminado e estigmatizado, outro dia vi uma reportagem que no cemitério de Brasília não tinha cova do tamanho do morto, porque o tamanho das covas são padronizados. Até caixão para obesos não tem, tem que ser enterrado em caixote improvidado. É muito triste..."

A9 - "Quando fui ganhar bebê o médico me criticou dizendo que era para eu aprender a fechar a boca, por isto que eu estava pesada e passando mal."

A10 - "Os banheiros de shopping possuem divisórias que deixam os box pequenos, sempre tinha que usar o banheiro de deficiente."

A11 - "Existem poucos lugares adaptados, os obesos estão aumentando e o governo não está se dando conta. Os obesos 
também são consumidores e muitos trabalham, somente não saem para consumir porque não tem lugares apropriados. São grandes consumidores em potencial."

A12 - Mesas e cadeiras de plástico, já cai destas cadeiras, muito fracas, não frequento lugares com estes materiais, prefiro não ir ou em último caso ficar em pé."

A13 - "Gordo não frequenta somente supermercado, ele é gente como todo mundo, e o resto da população considerada magra se esquece disto. Na minha opinião obrigatoriamente todos os lugares deveriam ser adaptados, os banheiros de shopping são estreitos, os brinquedos dos parques de diversão são pequenos e tem limite de peso. O obeso como qualquer outra pessoa tem o mesmo direito de frequentar lugares e participar dos eventos sociais, o excesso de peso não pode ser uma barreira, uma prisão para uma pessoa."

A14 - "A pior coisa que existe é um olhar de reprovação quando a gente entra em um restaurante, lojas até nos elevadores. As pessoas ficam com medo de o elevador cair."

$A 15$ - "Eu amo dançar, eu sei dançar, mas infelizmente não me sinto bem nos lugares, nas festas, as pessoas não falam, mas olham e cochicham."

$A 16$ - "Um bom exemplo são os hotéis, não tem quarto adaptados para obesos, já vi para deficientes físicos, mas para obesos nunca. Eu tinha medo de quebrar as camas e cadeiras dos hotéis e restaurantes."

A17 - "Ninguém quer namorar gente gorda. Sofro com isto."

$A 18$ - "Os gordos não existem. É uma vergonha ser amigo de gordo, todo mundo olha para o gordo."

A19 - "Homem magro com mulher gorda, todo mundo olha. Sofri muito preconceito por ser gorda, alguns namorados nem ligavam, outros caiam fora e eu ficava na mão."

A20 - "A vida amorosa é difícil, homem gordo é mais aceitável que mulher gorda, já sofri por causa do peso, arranjar um namorado é um sacrifício para o gordo."

A21 - "As cadeiras dos aviões são apertadas demais, um sufoco, não viajo há muito tempo, tenho medo de ficar entalada."

A22 - "Tudo é ruim, começa pelo próprio corpo que não ajuda em nada, depois os outros que também não ajudam, pelo contrário, te deixa mais deprê."

A23 - "Uma coisa horrorosa e fazer a prevenção-papanicolau, aquelas macas são um terror, tenho medo de cair, totalmente desconfortáveis e apertadas, junta isto com a vergonha da obesidade."

A24 - "Nem sei o que falar, é tudo muito difícil, desde o vestuário, ambientes não adaptados e ainda tem os mobiliários, precisei de uma cama reforçada e não encontrei nas lojas, tive que mandar fazer." 
A25 - "Subir escadas, rampas, é tudo ruim, amarrar sapatos era um inferno, não gosto nem de lembrar."

De acordo com Haddad et a ${ }^{288}$ e Pinheiro ${ }^{289}$ a obesidade por si só já é um fator estigmatizante e o obeso é influenciado pelo ambiente, em caso de rejeição este será percebido como algo a ser isolado, descartado, por ser considerado inútil. A sociedade esquece que a pessoa, em muitos casos, se tornou obesa por influência do ambiente opressor em que vive ou viveu.

Quando questionados sobre em quais lugares já sofreram preconceitos, $24 \%$ alegaram ambiente familiar, $40 \%$ na escola enquanto alunos, $48 \%$ na escola enquanto professor, $52 \%$ no trabalho por colegas, $20 \%$ no trabalho por parte de pacientes, $32 \%$ no ambiente hospitalar como paciente, $60 \%$ afirmaram terem sofrido preconceito em shopping ou lojas e $64 \%$ no transporte público. A seguir as falas dos participantes que desejaram compartilhar experiências sobre a questão:

A1 - "Posicionamento na aeronave, o gordo é sempre colocado nos piores lugares, de preferência nas últimas cadeiras, já aconteceu comigo."

A3 - "Discriminação em lojas de roupas, os vendedores não esperam você perguntar sobre um determinado produto e já vai falando que não tem o meu número. Muitas vezes eu ouvi isto, sendo que sai para comprar roupas para minha filha que é magra."

$\boldsymbol{A 6}$ - "Em acampamentos da igreja, o coordenador dividia as pessoas em grupos e eu percebia que ninguém me queria porque ficavam com medo de perder as competições por causa do meu peso."

A7 - "Ficar "entalada" em catraca de ônibus e metrô."

$A 10$ - "As 'Vans' de transporte coletivo nunca parava pra mim, eles nunca param para a pessoa gorda porque dizem que ocupam dois lugares."

$A 11$ - "Cadeira de plástico, estas de bar, quebrou por não suportar meu peso. Foi um vexame, não frequento mais lugares que tenha cadeiras de plástico, elas não são fabricadas para gordos."

$A 12$ - "Ficar sendo referência de sua própria pessoa, ninguém te chama pelo nome, sempre fala 'o gordinho'. Ou quando alguém está te procurando e não te conhece e alguém fala 'é um baixinho gordinho de blusa verde'. Isto é maneira de apresentar alguém?"

$A 15$ - "As cadeiras de ônibus, metrô e aviões são sempre apertadas e os cintos não fecham, é muito constrangedor ter que pedir um extensor do cinto." 
A16 - "Na adolescência um garoto que eu gostava muito, disse que não namorava baleia porque ele não era pescador."

A18 - "No meu trabalho o ambiente não foi planejado para que a pessoa obesa pudesse ter acessibilidade, o banheiro é apertado, a porta do banheiro é estreita, as cadeiras são para pessoas magras, eu sofro muito e não adianta brigar, nada é feito para melhorar."

A19 - "Cansei de ser citada em piadas e brincadeiras entre amigos, às vezes a gente suporta para poder ter vida social, sei que é errado aceitar estas coisas, mas caso contrário não ia mais poder sair, ter amigos."

Estas declarações reforçam ainda mais a existência do sofrimento psicológico e social. Durante a entrevista somente 10\% alegaram não sofrer preconceito. O preconceito contra a pessoa obesa ocorre em diversos lugares. Os ambientes citados que representam altos índices de preconceitos sofridos pelos participantes são escola, trabalho, shopping e no transporte público. Isto demonstra que os que praticam atos discriminatórios não reconhecem o outro como igual, tratando-os como estranhos que não compartilham os mesmos costumes.

A discriminação e o preconceito embora sejam considerados crimes, ainda são práticas recorrentes na sociedade brasileira. As pessoas que sofrem preconceitos, ao longo da vida desenvolvem falhas referentes aos princípios éticos e morais presentes nos ambientes sociais, passam a perceber que não fazem parte destes princípios e dos direitos sociais por serem agredidas constantemente. As instituições, principalmente de educação e saúde devem observar e intervir quando estes problemas ocorrem e incluir as pessoas com excesso de peso e obesidade em todas as atividades de forma natural e sem dificuldades. Educar de forma preventiva e saber contornar os conflitos ainda é a melhor solução.

Quando os participantes foram questionados se eles se consideravam uma pessoa normal ou um doente sobre seu peso corporal anterior a CBM, $45 \%$ responderam que se consideravam pessoas normais enquanto $55 \%$ se consideravam doentes. Em relação à presença de comorbidades enquanto obesos, as doenças mais sinalizadas estão distribuídas na Tabela 6, a seguir: 
Tabela 6. Doenças relacionadas à obesidade antes do tratamento cirúrgico.

\begin{tabular}{|c|c|c|}
\hline & $\mathrm{n}^{\circ}$ & $\%$ \\
\hline $\begin{array}{l}\text { Síndrome da Apneia } \\
\text { Obstrutiva do Sono (parar } \\
\text { de respirar enquanto } \\
\text { dormia) }\end{array}$ & 04 & 16 \\
\hline $\begin{array}{l}\text { Dispneia (falta de ar) a } \\
\text { pequenos esforços }\end{array}$ & 02 & 08 \\
\hline Síndrome do Ronco - & & \\
\hline Roncador & 03 & 12 \\
\hline Diabetes mellitus & 13 & 52 \\
\hline Hipertensão Arterial & 19 & 76 \\
\hline $\begin{array}{l}\text { Doenças cardiovasculares } \\
\text { doenças do coração e } \\
\text { circulatório) }\end{array}$ & 15 & 60 \\
\hline $\begin{array}{l}\text { Dificuldade de locomoção } \\
\text { (dificuldade para andar) }\end{array}$ & 08 & 32 \\
\hline $\begin{array}{l}\text { Dislipidemias (colesterol } \\
\text { alto) }\end{array}$ & 19 & 76 \\
\hline $\begin{array}{l}\text { Esteatose } \\
\text { (excesso de gordura no } \\
\text { fígado) }\end{array}$ & 05 & 20 \\
\hline Refluxo esofageano & 18 & 72 \\
\hline
\end{tabular}

Fonte: Dados da pesquisa, 2016.

Todas as doenças apontadas no questionário, escolhidas por ser associadas à obesidade mórbida, foram assinaladas, contudo as que mais prevaleciam na vida dos participantes antes da CBM eram a Hipertensão Arterial (76\%), o Diabetes (52\%), Dislipidemias $(76 \%)$ e doenças cardiovasculares $(60 \%)$. Estes dados corroboram com outros estudos que a obesidade mórbida apresenta riscos de desenvolvimento de doenças crônicas progressivas e incapacitantes. A Tabela 7 a seguir permitiu analisar o grau de obesidade dos participantes antes da CBM, estes apresentavam IMC entre 35 e $40 \mathrm{~kg} / \mathrm{m}^{2}$, sendo que $52 \%$ apresentavam IMC maior ou igual a $40 \mathrm{~kg} / \mathrm{m}^{2}$ e $28 \%$ IMC entre 35 e $39,9 \mathrm{~kg} / \mathrm{m}^{2}$, isto mostra que além do excesso de peso 
apresentado em graus II e III havia também a presença de comorbidades para que a CBM fosse realizada.

Tabela 7. Classificação do Peso Corporal antes do tratamento cirúrgico.

\begin{tabular}{lccc}
\hline \multicolumn{1}{c}{ Peso Corporal } & IMC & no & $\%$ \\
\hline Normal & $20-24,9$ & - & - \\
\hline Sobrepeso & $25-29,9$ & - & - \\
Obesidade Leve Grau I & $30-34,9$ & - & - \\
Obesidade Moderada Grau & $35-39,9$ & 07 & 28 \\
II & & & 52 \\
Obesidade Grave Grau III & $\geq 40$ & 13 & \\
\hline
\end{tabular}

Fonte: Dados da pesquisa, 2016.

Em alguns casos a CBM pode ser realizada em pessoas que apresentam IMC a partir de $35 \mathrm{~kg} / \mathrm{m}^{2}$ desde que portadoras de doenças que justifiquem o procedimento. Antes da resolução CFM no 2.131/2015 ${ }^{117}$ somente os pacientes que apresentavam IMC entre 35 e $40 \mathrm{~kg} / \mathrm{m}^{2}$ e tivessem doenças diretamente associadas à obesidade como diabetes tipo 2, apneia do sono, dislipidemia, doenças coronárias, osteo-artrite e outras poderiam ser indicada a CBM.

Com esta nova resolução a lista de doenças foi ampliada, incluindo mais de 20 comorbidades, sendo que para pacientes que apresentam IMC igual ou acima de $40 \mathrm{~kg} / \mathrm{m}^{2}$ a CBM pode ser indicada com ou sem a presença de comorbidades. Isto trouxe benefícios ao grupo que apresentava obesidade e doenças correlacionadas, mas que não tinham o IMC anteriormente definido para indicativo da CBM. Esta decisão vem reafirmar que a CBM não tem a função apenas de perda ponderal, mas que em um futuro próximo poderá haver indicação para pessoas com IMC menor que $35 \mathrm{~kg} / \mathrm{m}^{2}$, mas que possuem diabetes, por exemplo. A tendência das pesquisas sobre as técnicas e consequências da CBM no organismo é ampliar o número de doenças que podem ser tratadas por meio do procedimento e beneficiar um maior número de pessoas e a sociedade. 
Um destaque importante para este estudo quando faz a ligação entre a DUBDH em seu artigo 11 que trata da não-discriminação e não-estigmatização com a obesidade e a CBM que corroborando assim com a resolução CFM oㅜ $2.131 / 2015^{117}$ que inclui a estigmatização social como um dos critérios de indicação para o procedimento. Isto reforça o estigma da obesidade como um dos fatores de aumento do peso, exclusão e adoecimento físicopsicosocial. A aceitação negativa da pessoa obesa contribui para comportamentos agressivos ou de retração, assim bem como suicidas, compulsões e inércia física.

A obesidade é associada a uma série de valores morais negativos por trazer consequências não somente a saúde individual, mas também coletiva por ser responsável por alterações importantes de dados epidemiológicos das DCNT e possíveis modificações identidade social do obeso. Para reverter à condição de estigmatizados os obesos se submetem a diversas terapias que em muitos casos não apresentam o resultado esperado.

Nos EUA um movimento denominado fat pride tem abordado e discutido questões sociais que depreciam a pessoa com obesidade tendo como finalidade modificar determinados comportamentos sociais relacionados à discriminação e estigmatização, incentivando a tolerância à obesidade na sociedade moderna. Este movimento tem sido adotado em diversos países, inclusive no Brasil, porém de forma ainda tímida. Por isto a conscientização por meio da educação, com a participação de bioeticistas, deve ser adotada em diferentes ambientes abrindo espaços dialógicos para troca de informações, empoderamento e despertamento sobre o tema ${ }^{290}$.

É importante enfatizar que a CBM não é capaz sozinha de solucionar o problema obesidade, outros tratamentos devem ser associados, como uma boa nutrição e atividades físicas regulares. Quando os participantes foram questionados sobre realização de atividade física antes da CBM, 70\% responderam que não praticavam nenhum tipo de atividade física e 30\% que praticavam algum tipo de atividade física. Isto mostra que a inatividade física colabora para o aumento de peso e aumenta riscos para o aparecimento de doenças crônicas. 
A obesidade mórbida compromete não somente à saúde do portador, mas diversas áreas são afetadas, o sistema emocional humano é abalado e atinge principalmente a autoestima, podendo levar a pessoa obesa a depressão e dificuldade de aceitação da própria imagem corporal. A pressão social também reforça a rejeição pessoal e coletiva do corpo obeso causando dificuldades nas relações com 0 mundo exterior. A Tabela 8 a seguir representa uma autoavaliação dos participantes sobre a funcionalidade do corpo obeso no dia a dia e interação com a sociedade.

Tabela 8. Autoavaliação: Histórico Físico e Social antes do tratamento cirúrgico:

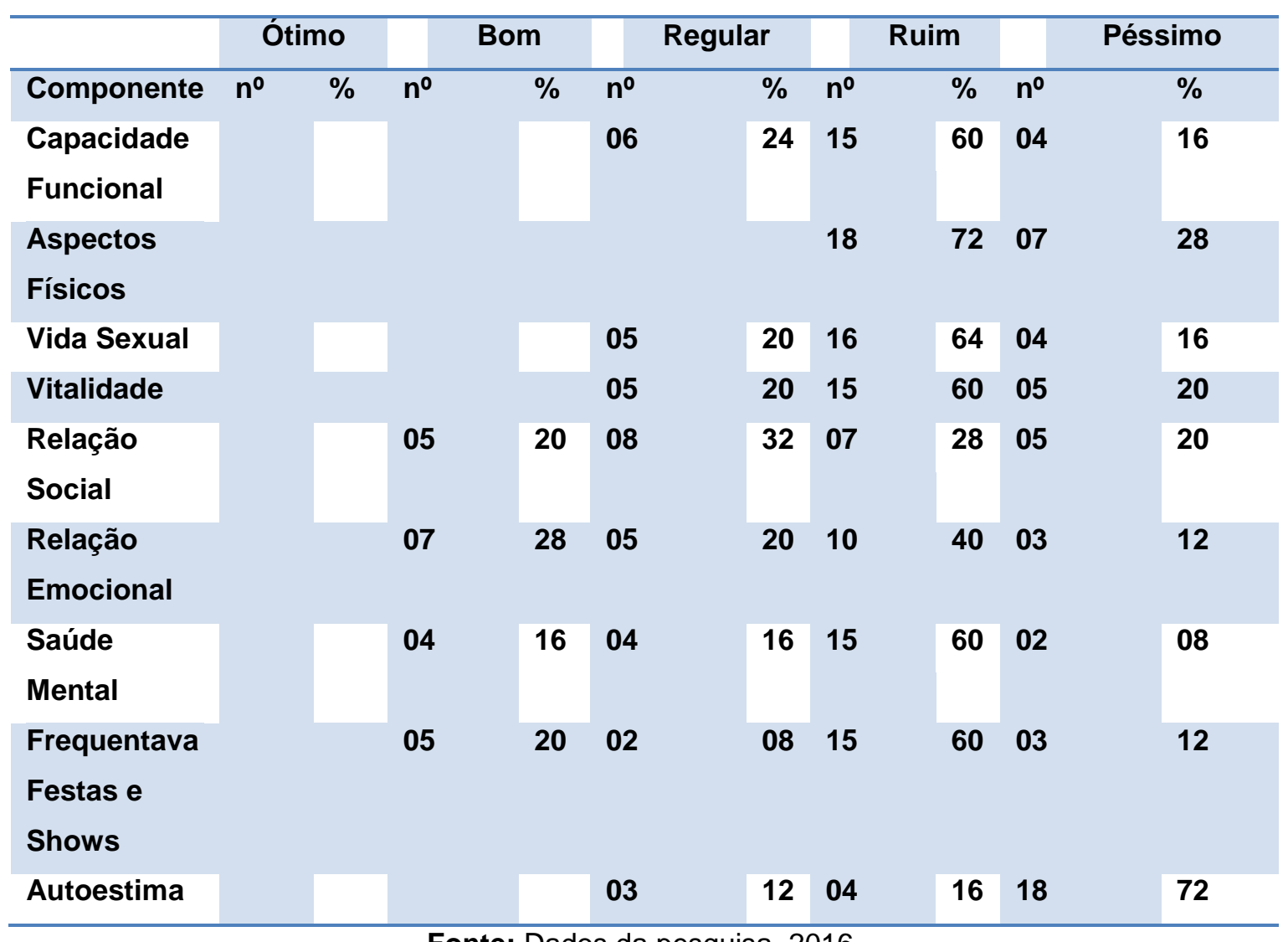

Fonte: Dados da pesquisa, 2016.

O histórico físico e social dos participantes antes da CBM mostra o quanto a obesidade causa exclusão, deterioração da identidade e das relações sociais. Sobre a capacidade funcional do organismo $60 \%$ disseram que era ruim e $16 \%$ que era péssimo, já em relação aos aspectos físicos $72 \%$ afirmaram que era ruim e $28 \%$ que era péssimo. Em relação a avaliação da 
vida sexual $64 \%$ declaram ruim e quando questionados sobre a vitalidade $60 \%$ também declaram ruim e 32\% assinalaram a opção regular. Quando abordados sobre o tema relações sociais $28 \%$ assinalaram a opção ruim. E sobre as relações emocionais $40 \%$ declaram que era ruim e $60 \%$ afirmaram que a saúde mental também era ruim. Sobre participar de eventos sociais como festas e shows $60 \%$ escolheram a opção ruim, e sobre a autoestima $72 \%$ afirmaram que era péssimo.

Os dados expressam que a tríplice relação entre obesidade, imagem corporal e sociedade é mais complexa do que parece, estes elementos possuem relações mútuas e estão interligadas. A obesidade é uma ofensa emocional para o portador causando baixa autoestima e comprometendo os hábitos e comportamentos diários, gerando frustrações e ansiedade e consequentemente dificuldades nas relações interpessoais (conjugais, sexuais e afetivas).

$O$ excesso de gordura se torna uma blindagem para evitar relacionamentos e não investir na sexualidade. A presença da timidez, do desânimo, da baixa qualidade de vida social, das dificuldades de relacionamento familiar e social em decorrência da obesidade tem relação direta com o aumento de cortisol circulante e aumento do estímulo da fome, o que gera um círculo vicioso que envolve estresse-ansiedade-alimento ${ }^{298}$.

Diante de uma vida restrita e difícil, muitas são as alternativas para alcançar o peso normal. Existem inúmeros tratamentos e estratégias disponíveis, contudo o problema maior é manter o peso na maioria dos casos. A perda de peso é dependente de um consumo energético negativo, de uma ingesta de baixa caloria e para isto é necessário um esforço pessoal associado a métodos de tratamento e mudanças de hábitos.

Quando abordados sobre quais tipos de tratamentos para a obesidade já haviam utilizado antes da CBM, 60\% responderam dietas hipocalóricas, 65\% atividade física, $100 \%$ já fizeram uso de medicamentos. Sobre a procura pela CBM como alternativa de tratamento definitivo, $65 \%$ responderam que a busca 
por uma saúde melhor foi o motivou da procura pelo procedimento enquanto $35 \%$ responderam que o motivo principal foi melhorar a estética.

A busca pela saúde e bem-estar é fundamental, contudo existe outro contexto em que as pessoas estão preocupadas em obter uma estética vendida e direcionada para o alcance da felicidade e da saúde, colocando em segundo plano o tratamento de doenças, o prolongamento vital e a qualidade de vida. Mesmo não sendo um dos objetivos diretos da CBM, algumas pessoas afirmam procurar o procedimento como alternativa para reconstruir o corpo e obter uma nova estética corporal compatível com a exigida pela sociedade. $\mathrm{O}$ que confirma a afirmação de Le Breton ${ }^{291}$ quando diz que o modelo de beleza muda de acordo com a diminuição significativa do manequim considerado ideal. Este conflito entre o corpo ideal e o real abre um amplo leque de busca de soluções como dietas, cirurgias, exercícios e anorexígenos.

Qualquer julgamento, sem conhecimento de causa, sobre a realização da CBM tendo como objetivo principal obter uma nova imagem corporal é no mínimo precipitado e injusto. O candidato a CBM mesmo que tenha a princípio o desejo de mudar a estética, também tem que se enquadrar no perfil determinado para a realização da CBM conforme protocolo do CFM. Na mente do indivíduo pode ser uma solução somente estética, mas para os profissionais os objetivos principais são outros. Contudo esta afirmação pela estética não pode e não deve surpreender, pois a discriminação sobre a pessoa com obesidade mórbida é real, compromete direitos fundamentais, restringe e prejudica a pessoa no contexto social, cultural, político e econômico.

Quando os participantes foram questionados sobre como eles achavam que as pessoas os percebiam antes da CBM. As respostas transcritas a seguir partem de suas próprias percepções e experiências vividas em relação ao olhar do outro em relação ao corpo obeso.

A1 - "Acho que me achavam preguiçosa porque havia coisas que eu não fazia porque não conseguia devido ao peso."

A2 - "Com certeza me achavam uma pessoa gorda, enjoada, mal humorada." 
A3 - "Uma comilona, mas eu era mesmo, comia muito e com gosto, deveriam me achar mal-educada sei lá."

A4 - "Eu sempre me preocupei com a limpeza do meu corpo, mas o obeso transpira demais, acho que as pessoas tinham nojo, pensam que gordo não toma banho direito."

A5 - "Viam-me obesa e diziam que eu tinha que emagrecer, acho que viam meu sofrimento."

A6 - Quer saber, as pessoas me viam como todos os gordos, acham que somos preguiçosos e sem vontade, pensam que emagrecer é fácil."

A7 - "Um dia não consegui fazer um determinado procedimento e um colega disse: tá vendo porque você tem que emagrecer, daqui a pouco nem vai conseguir levantar da cadeira. Depois deu um sorriso e disse que era brincadeirinha. Tudo é brincadeirinha, mas eu sei que isto se chama preconceito."

A8 - "Me achavam infeliz, triste, insatisfeita, eu era assim mesmo, meu corpo e minha face transmitiam isso, não suportava aquela vida."

A9 -"Uma gorda comilona, preguiçosa. O obeso passa a impressão de preguiçoso."

A10 - "Já fui agredida dentro do ônibus, me chamaram de gorda e me empurraram. Muitas pessoas não gostam de sentar perto de gordos. Acho que elas têm nojo da gente."

A11 - "Infeliz, uma pessoa infeliz. O obeso é percebido como alguém desleixado."

A12 - "Me viam uma pessoa feliz, sorridente, eu nunca deixava transparecer minha tristeza."

A13 - "Minha chefe ficava falando coisa a meu respeito, muitas pessoas vinham me falar, dizia que eu era preguiçosa e que usava a gordura para não querer trabalhar."

A14 - "Me viam como um fardo."

A15 - "A cara de insatisfação dos vendedores nas lojas de roupas e sapatos quando solicitamos um número maior, eles nos atendem com má vontade, esquecem que somos consumidores também. Penso que eles sentem raiva dos gordos."

A16 - "Que eu era feliz, mas que poderia melhorar minha aparência".

A17 - "Me viam feia, desajeitada e desarrumada. Não tinha prazer em me arrumar, tudo ficava feio em mim."

A18 - "Acho que tinham vergonha de mim, de ficar ao meu lado, de comer perto de mim, me viam como uma pessoa comilona."

A19 - "Falavam que eu roncava demais e que eu tinha que emagrecer."

A20 - "Diziam que eu era bonita, mas a gordura atrapalhava." 
A21 - "Me achavam feia e desleixada."

A22 - "Penso que me achavam preguiçosa e com falta de vontade de emagrecer."

A23 - "A palavra certa é desleixada."

A24 - "Sem vontade, sem força, uma pessoa fraca."

A25 - "Preguiçosa, sempre cansada, sem força."

As respostas demonstram em sua maioria não somente 0 que supostamente as outras pessoas pensavam, mas, percebe-se que existe um estigma e discriminação por parte do próprio participante pelas próprias palavras expressas como preguiçosa, triste, desarrumada, feio, desleixada, fraca, infeliz, nojo, comilona e outras. É fato que as pessoas obesas enfrentam barreiras universais como o preconceito, estigma e discriminação que passam pelo percurso que vai desde uma simples piadinha ou apelido até o estágio final que é a violência física. Este estudo possibilitou abrir um canal de escuta para estas pessoas, atentar ao que está sendo dito e sentido, possibilitando assim uma ruptura de uma situação ruim que pode ser discutida, transformada, socializada e politizada.

A bioética em seus ambientes dialógicos deve abordar e preparar especialistas, famílias e sociedade em geral, para enfrentar a doença do milênio chamada obesidade em seus diferentes graus e que as causas estão muito além de qualidades morais como preguiça, falta de vontade, gula e carência emocional. O principal trabalho é o de conscientização, pois pessoas não obesas acusam as obesas como autoagressores, considerando-as as únicas responsáveis pelos danos causados em seus próprios corpos e que para serem respeitadas devem primeiramente respeitar seus corpos.

Este fenômeno é definido por Ryan ${ }^{292}$ como "blame the victim" em que a vítima é considerada culpada pelo que ocorre ou ocorreu, podendo este termo ser utilizado em diversos casos em que a discriminação, estigmatização e preconceitos estejam presentes como vitimas de estupros, etilistas,

\footnotetext{
${ }^{8}$ Termo cunhado por William Ryan em 1971 para descrever a acusação da vítima como uma ideologia para justificar a violência, principalmente em relação ao racismo e injustiças sociais que ocorriam nos Estados Unidos da América. Tradução da autora: blame the victim - culpar a vítima.
} 
homossexuais, prostitutas, portadores de doenças crônicas e estigmatizantes, estes são considerados culpados por estar nestas situações, à sociedade leiga descarta qualquer fator de interferência ou de culpa do ambiente nestes casos.

Ainda sobre o tema percepção, a mesma pergunta anterior foi feita aos participantes, somente sendo alterado o autor do olhar, que ao invés de ser do outro, seria o olhar do próprio participante. Sobre como ele se percebia ao se olhar no espelho antes da CBM. O objetivo era saber que julgamento a pessoa tinha de si mesma. Respostas a seguir:

$\boldsymbol{A 1}$ - "Me sentia feia, triste. Parecia que não era eu, aquela casca não representava meu interior, e isto me entristecia muito."

A2 - "Muito feia."

A3 - Eu quase não me via nua, não era bonita. E acho que as outras pessoas não tinham que ver e suportar aquilo, por isto não namorava mais."

A4 - "Estava tão desmotivada que vivia no meu mundo e quase não incomodava ninguém, queria ser transparente, o espelho é cruel porque mostra os seus defeitos sem que ninguém precise falar."

A5 - O espelho era meu inimigo, ninguém gosta de ver coisa feia, cheia de dobras, tem partes do corpo que o obeso só vê quando está de frente ao espelho, um terror."

A6 - "Acho que o espelho sempre me disse: você não está bem e um dia resolvi ouvi-lo."

A7 - "Muito gorda, desajeitada."

A8 - "Eu não me olhava no espelho porque era uma decepção." Me sentia feio, não era uma visão agradável.

A9 - "Meu corpo era esquisito, grande em umas partes, finos em outras, não era uma coisa uniforme, toda desengonçada."

A10 -"Se olhar no espelho, se encarar, olhar nos olhos, seus próprios olhos, é muito triste olhar e ter que dizer: você tá horrível, chorei muito."

$\boldsymbol{A 1 1}$ - "Eu não gostava do que via, eu queria outro corpo. Eu queria me livrar daquele corpo."

A12 - "É angustiante quando você está preso em um corpo que não representa a sua alma, sei lá, a sua personalidade. O corpo obeso passa má impressão."

A13 - "Eu sofria muito. Lutei e consegui o corpo do mais próximo que imaginei." 
A14 - "O meu corpo enquanto obeso era desagradável, o meu sentimento era este, parece que onde eu chegava não era bem visto. Queria me esconder, não me sentia bonita."

$A 15$ - "Eu não me conseguia me enxergar naquela imagem, respirava fundo e tantas vezes chorei."

A16 - "A pior coisa é você se adaptar ou fingir que gosta daquele corpo, era assim que eu me comportava, passava a impressão de que estava tudo bem. Maior mentira é quando você mente pra você mesmo."

A17 - "Horrivel."

A18 - "Eu tirava a roupa e ficava me olhando no espelho e isto me deu força para correr atrás da cirurgia, eu me sentia feia."

A19 - "Que aquela imagem não era eu, minha alma estava presa naquela fortaleza".

A20 - "Feia, tudo feio, nada."

A21 - "Sempre tentei viver da melhor maneira possível

A22 - "É muito triste. Uma visão triste, minha alma queria gritar, fugir, era uma imagem ruim"

A23 - "Eu me sentia mal, mas não podia fazer muita coisa, tinha que levantar a cabeça e seguir. Imagem feia."

A24 - "Se eu fosse outra pessoa olhando para meu corpo, não me escolheria para namorar naquela época, estava uma coisa esquisita."

A25 - "Aff! É cruel! Tirar a roupa e encarar aquele monte de banha, não é brinquedo não! Horrível."

Ao analisar as respostas sobre estas questões, inferimos que os discursos dos participantes em relação a seus próprios corpos estão inconscientemente submissos à normatização estética definida pelo mercado. O olhar no espelho tornou-se um ato de reprovação porque procuravam encontrar o corpo ideal que a sociedade exige, e isto despertava o pensamento de que as pessoas que não se enquadram nos padrões físicos ditos belos são consideradas feias e infelizes.

Em seu imaginário se consideravam "anormais" acreditando que o padrão de magreza é o certo, que ser magro traz felicidade e as tornam iguais. Se esquecem de olhar para as outras pessoas e perceber que existem diferenças físicas entre os indivíduos e que isto não as desqualificam, pelo 
contrário, pode ser um diferencial e variável de beleza. Se aceitar é a melhor solução, a CBM não modifica a personalidade e o caráter, sendo assim, apenas um complemento para uma potencial mudança de comportamento.

O papel da bioética também deve intervir de forma a conscientizar que 0 obeso é um reflexo de vários fatores intrínsecos e extrínsecos que influenciam diretamente no controle ou aumento da obesidade. É importante explicar que é extremamente difícil manter um equilíbrio emocional diante de comportamentos de discriminação e preconceito.

A exclusão social mesmo que de forma velada, porém percebida pelo obeso, traz danos graves à saúde do sujeito como a depressão e outras perturbações psicológicas, ao ponto da própria pessoa de achar preguiçosa, feia, suja e relaxada. Isto reforçar a existência da discriminação contra o obeso e que a sociedade aceita esta atitude negativa quando permite a divulgação e consome a ideia da magreza excessiva como algo a ser valorizado.

Ao contrário do que Callahan ${ }^{237}$ afirma sobre a implantação de medidas fortes na área econômica que tem como objetivo restringir o acesso a determinados produtos, assim como na área social e de saúde pública onde incentiva a uma abordagem mais agressiva, estigmatizadora, discriminadora e até mesmo cruel quando a ideia sugerida "estigmatização light" é de impor, envergonhar, inibir e restringir ações e comportamentos do indivíduo ao ponto deste sentir vergonha de si mesmo pela condição de obeso. Este estudo demonstra que não é necessário criar campanhas e ambientes estigmatizadores e discriminatórios porque eles já existem, não somente ambientes, mas comportamentos sociais não saudáveis sejam individuais ou coletivos sobre a não aceitação do outro.

A pessoa com obesidade em sua maioria não precisa ser despertada para a rejeição própria porque seja de forma consciente ou inconsciente ela mesma se reprova. A pessoa obesa necessita ser aceita, compreendida, educada, empoderada e reconhecer que a obesidade é sim uma doença, porém que não existe uma cura definitiva, mas que pode ser controlada e a 
partir daí mostrar que é possível viver e participar efetivamente da vida em sociedade. Talvez a intenção de Callahan seja um caminho para o controle da obesidade como último recurso para controle alimentar em tempos de escassez de alimento ou se em um futuro próximo os seres humanos perderem a capacidade de ser solidário com a dor do outro, de se colocar na posição do outro.

O mundo já vive dividido em "ambientes" de ilusões e discriminações, este modelo de "estigma light" pode produzir pessoas com distúrbios patológicos sérios. A obesidade deve ser analisada também do ponto de vista antropológico, observando os comportamentos, a importância da imagem corporal na sociedade, a busca pelo corpo perfeito, o perfil psicológico dos sujeitos que buscam a CBM. As relações entre as pessoas sejam elas gordas ou magras não deve ser baseadas no IMC, a sociedade quando padronizou um modelo de beleza esqueceu-se do pluralismo étnico e cultural.

Quando questionados sobre o que consideravam como maior problema em suas vidas em relação à obesidade antes da CBM, as respostas em sua maioria envolveram basicamente quatro motivos: (1) desgastes em relacionamentos; (2) críticas; (3) baixa autoestima e (4) doenças correlacionadas. Transcrições a seguir:

A1 - "Não aguentava mais os olhares de reprovação."

A2 - "As críticas, principalmente de familiares e amigos."

A3 - "As doenças correlacionadas com o excesso de peso, diabetes e hipertensão. Por isto resolvi buscar a cirurgia como solução."

A4 - "As críticas em relação a minha pessoa, sobre o excesso de peso, não suportava mais as fofocas e comentários desagradáveis. Foi isto que me fez escolher o tratamento cirúrgico."

A5 -"Estar infeliz comigo mesma, chegou uma época que eu queria morrer de tanta tristeza. Então decidi fazer a cirurgia."

A6 - "Os olhares me incomodavam. A obesidade atrapalhava demais."

A7 - "Meu marido estava desanimado comigo, nossa relação desgastada, quase separando. Ele gostava de mim, mas não desejava aquele corpo. Resolvi tentar a cirurgia e agora está tudo bem." 
A8 - "As doenças, uma hora era a pressão, outra hora o cansaço, depois o diabetes, uma coisa atrás da outra."

A9 - "Estava ficando cada dia mais doente, muitas doenças aparecendo e, além disso, mal podia andar, ficava cansada muito fácil. Foi o que determinou."

A10 - "Eu estava triste comigo mesma, precisava dar um basta."

A11 - "Insatisfação com meu corpo, geral. Também tinha medo de enfartar."

A12 - "As dificuldades do dia-a-dia, muito complicado para uma pessoa gorda, tudo é difícil."

A13 - "Nossa! As roupas, amarrar uma sandália, um tênis, calcinha, tirar a roupa na frente de outra pessoa era desconfortável demais. $E$ as doenças."

A14 - "Estava cansada da discriminação, das doenças, Mais o principal era o corpo grande e cheio de dobras."

A15 - "As críticas, isto me deixava infeliz."

A16 - "O preconceito das pessoas."

A17 - "Não gostava e não queria mais aquele corpo, precisava mudar."

A18 - "Estava morta dentro daquele corpo, não participava de festas, não saia pra lugar nenhum."

A19 - "Me fazia falta sair com meus amigos para festas, restaurantes, barzinhos...era de casa para o trabalho e vice-versa."

A20 - "Estava farta de ser chamada de gordinha. Queria ser chamada pelo nome."

A21 - "Quando alguém está com raiva de você, o primeiro palavrão é - sua gorda, seu gordo - isto dói. Estava cansada de mim e dos outros."

A22 - "As doenças estavam se agravando, e eu tenho vontade de viver mais, acho que tudo é válido para melhorar. Tinha medo da morte"

A23 - "Era tanta doença que eu tinha medo de morrer."

A24 - "As doenças, né. Medo de morrer ou ficar entrevada."

A25 - "A discriminação e o preconceito."

Muitos recorrem à cirurgia somente para emagrecer, os candidatos à CBM em sua maioria pensam que o procedimento mudará a sua vida por completo. A CBM traz mudanças físicas, mas também psicológicas, sociais e emocionais sejam elas satisfatórias ou não, contudo, de uma forma geral os 
pacientes apresentam significativa melhora na qualidade de vida e na imagem corporal, estes benefícios acontecem gradativamente.

Por outro lado, embora os fatores positivos prevaleçam, uma minoria pode desenvolver transtornos psicológicos após a CBM, embora o novo corpo traga a reintegração social pode surgir um sentimento de perda da identidade e desamparo que pode ser transitório ou duradouro, podendo neste período surgir desequilíbrio nas relações com familiares e cônjuges o que pode contribuir para o abandono do tratamento. Isto reforça que todos os problemas não serão resolvidos com o procedimento, mas a continuação do tratamento ajudará na aceitação do novo corpo, nas mudanças de hábitos alimentares e de comportamento e consequentemente na vida social, muitos dos problemas serão eliminados.

A CBM somente terá uma resposta positiva dependendo do objetivo da pessoa, que deverá ser a melhoria na qualidade de vida e não somente querer dar uma satisfação às idealizações e expectativas de familiares e da sociedade. Contudo é uma cirurgia que está associada indiretamente, em muitos relatos, com a felicidade, eliminação de estigmas, liberdade de movimentos, aumento da autoestima, a aceitação da autoimagem, bem-estar psicológico, autoconfiança, segurança, libertação e inclusão social. Como pode ser percebido nas respostas deste estudo sobre a seguinte questão "O que você esperava de mudança física e social em sua vida após a cirurgia?" transcritas a seguir:

A1 - "Sabia que o corpo ia mudar, esperava que mudasse tudo em minha vida."

A2 - "Ficar bonita, magra, poder sair de casa."

A3 - "Sabia que o corpo ia mudar porque vi pessoas que fizeram e emagreceram, e queria ser magra para me sentir aceita por todos e poder sair, passear, curtir a vida."

A4 - "Emagrecer e estourar meu cartão de crédito em roupas novas."

A5 - "Ficar de bem comigo mesma, poder me gostar e também namorar sem ter vergonha."

A6 - "Queria ser bonita e magra. Bonita não consegui, mas ser magro é ser magro, a beleza não importa muito." 
A7 - "Que a felicidade tem nome - ser magro - eu ia ser magra."

A8 - "Poder sair, festas, casamentos, aniversários, usar roupas elegantes. Mudar meu visual."

A9 - "Queria ser feliz, estar bem, me sentir livre para andar, falar, sem que ninguém ficasse me olhando de lado."

A10 - "A gente pensa que a cirurgia vai te trazer uma vida de atriz de cinema, mas o que ela te dá é apenas uma qualidade de vida melhor, as coisas seguem como antes, tudo dentro da normalidade."

A11 - "Mudança no corpo, ficar bonita, me vestir bem."

A12 - "Primeiro a saúde melhorar e depois levantar a autoestima".

A13 - "Eu só queria ser feliz."

A14 - "Me sentir livre, achava que a cirurgia ia me dá liberdade, com o corpo obeso não se tem muita liberdade."

A15 - "Eu queria viver, estava enclausurada, limitada, a cirurgia traz esta ideia de aceitação própria e social."

A16 - "Se eu disser que era somente preocupada com a saúde, estaria mentindo, queria e precisava emagrecer. É muito difícil julgar o outro, achar que é preguiça de ir para a academia. A estética é muito importante nos dias de hoje, infelizmente."

A17 - "Mudar o corpo era a minha ideia principal, lógico que a saúde também. As pessoas te cobram bastante."

A18 - "Vestir um número menor e viajar, viver."

A19 - "A cirurgia trouxe o que eu sempre sonhei, meu corpo magro, sai da prisão, aquela armadura grande e feia foi embora. Agora sou feliz, aconteceu o que eu mais queria."

A20 - "Saúde e liberdade."

A21 - "Eu só queria ser normal, como todo mundo."

A22 - "Com certeza ser emagrecer, mudar o corpo e ser aceito por todos, sem discriminação."

A23 - "A mudança no corpo, não me preocupava com as futuras plásticas reparadoras, eu queria emagrecer para poder viver."

A24 - "Emagrecer e ir a praia...nunca tinha ido a praia."

A25 - "Ter qualidade de vida, namorar, viajar, cuidar de mim, me amar...ninguém que não se ama pode amar outra pessoa. Eu precisava gostar de mim."

A obesidade não diminui o ser humano, pode ser considerada uma característica, uma diferença, uma diversidade. As diferenças corporais não devem ser motivos de exclusão e segregação social, por isto a construção de 
estratégias que eliminem as barreiras físicas, as barreiras sociais e principalmente as barreiras psicológicas do próprio individuo devem ser elaboradas e implementadas para a aceitação das limitações do outro como parte da construção social. As respostas deixam clara a desvalorização das pessoas enquanto obesas e como o preconceito social pode devastar 0 psicológico do indivíduo de forma a torná-lo uma pessoa retraída e envergonhada. Porém as expectativas e resultados apresentados após a realização CBM em relação à melhora na qualidade de vida são altamente positivos, destacando a elevação da autoestima e o desaparecimento de doenças correlacionadas, além da reinserção do indivíduo na sociedade.

A CBM pode ser considerada um processo de libertação, não somente da forma corporal obesa, mas ajudando administrar os problemas emocionais que se escondiam por trás dos alimentos. Por isto a continuidade do tratamento é importante para impedir reganho de peso por desequilíbrio dos fatores emocionais e retorno aos hábitos antigos. O procedimento CBM colabora para a aceitação social e permite um reencontro da própria identidade anteriormente deteriorada, rompe a baixa autoestima e com quase todos os problemas psicodinâmicos que trazem sofrimento. Como pode ser percebido nas respostas a seguir quando questionados sobre a percepção pessoal ao se olhar no espelho após a CBM:

A1 - "Bem, mesmo com alguns efeitos indesejáveis, é ótimo emagrecer."

A2 - "É ótimo ver o corpo mudar aos poucos, voltar a ser normal."

A3 - "Está dando tudo certo, estou me sentindo melhor, mais animada, disposta."

A4 - "Me encarando de frente e todas as mudanças, sentido bem comigo mesmo."

A5 - "Enfrentando o espelho muito bem, tendo mais força, ânimo e a autoestima elevada."

A6 - "Vejo uma mulher envelhecida, cheia de rugas e desanimada."

A7 - "Percebo alguém que luta pra viver e ser feliz, a cirurgia me trouxe de volta a vida." 
A8 - "Meu corpo melhorou bastante, o excesso de pele não me incomoda, já trabalhei isto na minha mente, vai sair logo, logo."

A9 - "O processo não é fácil, mas a força de vontade e maior e agora vejo que tomei a melhor decisão. Me sinto outra pessoa, me arrumo, trabalho, me divirto, tomo os cuidados necessários e tudo bem."

A10 - "O espelho diz que eu estou melhor, mais bonita, mais magra e com certeza mais segura."

$A 11$-"Estou um pouco magra porque já ganhei alguns quilos, não me adaptei às mudanças corporais e principalmente emocionais."

$A 12$ - "A visão é muito boa, bastante boa, ser magra sempre foi um sonho."

A13 - "Vejo alguém com força de vontade, uma nova pessoa com uma nova vida pela frente, eu me amo."

A14 - "Eu estou me adaptando a cada dia, me sinto forte, tem dias que não é fácil, mas no geral estou satisfeita."

A15 - "Me olho e digo, tive uma nova oportunidade na vida e vou aproveitar. Tudo ótimo."

A16 - "Está tudo mais tranquilo, estou em paz, aos poucos tudo se resolverá, não me arrependo."

A17 - "Como é bom viver a magreza...confiante, tenho mais vontade de levantar da cama e ir trabalhar."

A18 - "Emagrecer é bom, a cirurgia bariátrica é milagrosa, minha vida melhorou muito, minha imagem, minha alma. Agora é manter o peso."

$A 19$ - "Eu estou bem comigo e com os outros. Lutando para manter um boa dieta e na academia...não quero engordar nunca mais."

A20 - "A cirurgia me deu a oportunidade de iniciar uma nova vida, não quero perder meu tempo comendo. Animada e mais confiante."

A21 - "A cirurgia me ensinou que eu não devo viver para comer, eu como para viver. Estou ótima."

A22 - "Estou feliz, satisfeita, minha vida melhora a cada dia, minha saúde está boa."

A23 - "Tudo está bem, eu consigo me olhar no espelho agora e enxergar ao bonito, lógico que preciso de reparos, mas está melhor que antes."

A24 - "Estou feliz, animada, com força para trabalhar e vontade de viver."

A25 - "Feliz."

O procedimento cirúrgico é pertinente e tem sido indicado e realizado com uma frequência cada vez maior. O SUS oferece a CBM gratuitamente e 
prioritariamente a pacientes diagnosticados com obesidade mórbida que estão classificados com alto risco de doenças graves e risco de morte. Como é um processo demorado e bastante procurado, pois os candidatos precisam passar por vários especialistas e frequentar reuniões o que requer tempo e paciência, muitos indivíduos procuram fugir da fila do SUS e buscar outros caminhos como planos de saúde, consórcios de cirurgias plásticas (carta de crédito) e até mesmo optar em pagar a cirurgia mesmo que por meio de empréstimos bancários.

Os resultados da pesquisa mostram que $60 \%$ dos participantes realizaram o procedimento por meio de convênios, enquanto $20 \%$ particular e $20 \%$ realizaram pelo SUS. Sobre o tempo de gastroplazizados, $65 \%$ há mais de cinco anos, $25 \%$ mais de quatro anos, $10 \%$ há mais de três anos. Todos os participantes, isto é $100 \%$, afirmam ter sido acompanhado por uma equipe multiprofissional antes, durante a após a CBM, e em relação ao tempo de preparação transcorrido desde a primeira consulta até o ato cirúrgico variou bastante, $12 \%$ em menos de um ano, $20 \%$ em um ano, $16 \%$ em dois anos, $08 \%$ em três anos e $12 \%$ em quatro anos.

Sobre o recebimento de informações pela equipe multidisciplinar em relação aos possíveis benefícios e danos à saúde, 100\% afirmaram terem recebido toda informação necessária, assim bem como a informação de que a CBM é um ato cirúrgico complexo, definitivo, de grande porte, que envolve risco de morte e necessita de manutenção do tratamento por toda vida, incluindo cirurgias reparadoras, suplementação nutricional e dieta equilibrada. Contudo, somente $45 \%$ afirmaram que continuam participando das reuniões e consultas com a equipe multidisciplinar e 55\% afirmaram não participar das reuniões e as consultas, exceto em casos de urgência.

Sobre o acompanhamento psicológico, 90\% afirmaram que não estão sendo acompanhados por psicólogos e 10\% continuam com 0 acompanhamento psicológico. Os dados mostram a não adesão à continuidade do tratamento como não frequência em reuniões e avaliações com os profissionais, principalmente psiquiatra e psicólogos. Destarte, é importante destacar a importância da avaliação psicológica não somente no pré-operatório 
para determinar a aptidão do paciente à cirurgia, mas também no período trans e pós-operatório, pois é necessário o paciente compreender as mudanças de estilo de vida, avaliar os resultados, compartilhar experiências, as satisfações, as insatisfações, o funcionamento cognitivos, a autoestima, e também detectar o aparecimento de traumas e ideias suicidas.

Passar pela CBM não é sinônimo de derrota do inimigo, com o tempo podem surgir alterações comportamentais e sensações de angústia, vazio, de falta de alguma coisa, uma tristeza, apatia, o que demonstra que a obesidade era apenas um dos fatores da insatisfação e que existem outros que ainda devem ser acompanhados e trabalhados. A não continuidade do tratamento pode ter como consequência a volta do peso inicial antes da cirurgia por compulsão e depressão ${ }^{293,294}$.

A CBM trouxe resultados significativos na vida da maioria dos participantes trazendo qualidade de vida e melhora de doenças relacionadas à obesidade e que $60 \%$ dos participantes já atingiram o peso ideal, mostrando que os procedimentos apresentam uma boa curva de emagrecimento e que doenças correlacionadas foram eliminadas ou estão sendo reduzidas. Algumas doenças prevaleceram na vida dos participantes após a CBM como o Diabetes mellittus que ainda está presente em 16\% (4) dos participantes, hipertensão arterial permanece em $24 \%$ (6) deles e doenças cardiovasculares $12 \%$ (3), contudo representavam respectivamente antes da CBM 52\% (13) diabéticos, $76 \%$ (19) hipertensos e 60\% (15) doenças cardiovasculares dos participantes deste estudo. Sendo que síndromes como apneia obstrutiva do sono e do ronco, as dislipidemias, dispneias, algumas doenças cardiovasculares, dificuldade de locomoção, esteatose hepática e refluxo esofagiano foram eliminadas ou minimizadas como consequência dos resultados positivos da $\mathrm{CMB}$, isto significa melhora clínica e na qualidade de vida.

As doenças que permaneceram são controladas por meio de medicamentos, alimentação e prática de exercício físico. Segundo PalazuelosGenis et $a^{295}$ a perda de peso acima de $10 \mathrm{~kg}$ é suficiente para uma melhora clínica da hipertensão arterial e outras doenças cardíacas e endócrinas como o diabetes, além de reduzir os níveis lipídicos. $O$ diabetes, segundo estudos de 
Rizzelo et $a^{296}$,é uma doença relacionada à obesidade e está presente em $8 \%$ dos homens obesos e $20 \%$ nas mulheres obesas. Já estudos como o de Menenakos et a ${ }^{297}$ mostram que $88,8 \%$ dos pacientes tem melhora significativa do diabetes e hipertensão pós CBM e que $50 \%$ dos pacientes que eram hipertensos houve a suspensão da medicação.

Estes resultados demonstram que a CBM não tem somente o fim de controlar o excesso de peso, mas controlar o diabetes, sendo assim a CBM se torna um procedimento com efeito protetor na prevenção de problemas metabólicos. Além da redução do peso e doenças correlatas, a adequação e inclusão social que as mudanças corporais decorrentes da CBM produz são extremamente positivas.

Os obesos antes vistos como seres com imagem corporal inadequada e representantes de enfermidades severas geravam desconforto visual no outro e exclusão social ao portador pela insatisfação e solidão. A exclusão não significa apenas rejeição física, geográfica, de classe social, trabalho, acesso a bens e serviços, não é uma questão apenas de apartação social, mas é reconhecer o outro como não-semelhante. Como define Martins ${ }^{298}$ (p.18) "a exclusão é apenas um momento da percepção que cada um e todos podem ter daquilo que corretamente se traduz em privação.".

Sobre a existência das dificuldades do dia a dia, da discriminação e da estigmatização pós CMB, 95\% afirmaram que estes fatores desapareceram com a perda e $5 \%$ afirmaram que ainda há preconceito e discriminação em relação ao corpo flácido e com excesso de pele. Relatos dos participantes que quiseram compartilhar experiências sobre discriminação, estigmatização e percepção do outro após CBM, a seguir:

A6 - "Não existe discriminação em relação ao corpo, tudo mudou. Ser gordo é nojento, as pessoas não gostam de gordo. Sobre a percepção do outro: acho que eles me veem fraca, abatida, malhumorada, introvertida, sem coragem para nada, fiquei medrosa com medo de morrer, consequência da anemia que não cura nunca pós cirurgia."

A7 -"As pessoas passam a te tratar melhor, lógico que muda, tudo muda, a vida ficou melhor, sou aceita em todos os ambientes, a gente percebe nos olhares. Meus filhos dizem que mudei de humor, para melhor, estou mais sorridente." 
A8 - "A magreza te traz alegria, a discriminação foi embora junto com o tecido adiposo. Recebo elogios por estar me vestindo melhor. Meu marido me incentiva a melhorar cada vez mais. As pessoa te enxergam diferente."

A10 - "Graças a Deus, tudo acabou, as críticas, os olhares. As pessoas me tratam como se eu nunca tivesse sido gorda. As pessoas valorizam a aparência, minha aparência mudou, estou mais bonita e todo mundo me elogia."

$A 11$ - "O excesso de pele ainda me incomoda e aos outros também, os olhares agora é para determinadas partes expostas do corpo que mostram o excesso de pele."

$A 12$ - "Não sofro mais com o preconceito, mas é lamentável saber que o valor das pessoas está no tamanho do corpo e não no tamanho da sua alma. Antes vivia oprimida, cabisbaixa, sem ânimo, agora eu saio, viajo."

A14 - "O excesso de pele é horrível, as pessoas olham e acham feio, mas faz parte do processo."

A15 - "A obesidade incomoda, o excesso de pele incomoda, as cicatrizes incomodam os outros, isto significa que ainda existe discriminação. Contudo eu me sinto bem, estou feliz, prefiro ser magro, não me importo com as cicatrizas das plásticas."

A maior parte dos participantes, representada por 92\% (23) afirmaram que a CBM atendeu seus objetivos e relatam satisfação enquanto $8 \%$ (2) afirmaram insatisfação e não alcance dos objetivos. Sobre arrependimento em realizar o procedimento apenas $8 \%$ assinalaram arrependimento de ter submetido à CBM, relatos a seguir:

A6 - "Me arrependo. Estou gorda de novo, minha saúde piorou, nunca tive anemia agora tenho que tomar medicamento para anemia. Vivo desanimada, sem força, fraca, hipoglicemia direto, minha filha não deixa eu brincar com meus netos com medo de dar hipoglicemia e eu cair com eles."

A11 - "Me arrependo amargamente, era feliz gorda e podia fazer o que eu queria. Agora tudo me faz mal, me sinto infeliz."

A reconstrução corporal por meio da CBM e outras cirurgias plásticas pós redução de peso corpóreo traz elevação da autoestima, autoaceitação, segurança, disposição física, ativa a sensualidade e sexualidade facilitando a relação com o outro. Existem estudos que mostram relatos de obesos afirmando que se pudessem escolher entre a obesidade e outras condições socialmente estigmatizantes como herpes, cegueira total ou alcoolismo, 
preferiam qualquer um destes menos a obesidade. Raros os casos de insatisfação com os resultados pós CBM que podem surgir por despreparo psicológico, a não aceitação das mudanças corporais e não adaptação aos novos hábitos alimentares, o que gera frustração, reganho de peso e transtornos psicológicos como depressão, baixa autoestima e repressão sexual, por isto a importância do acompanhamento por equipe multidisciplinar $283,299,300$.

Muitos obesos mórbidos e gastroplastizados relutam em ser acompanhados por psicólogos e psiquiatras por se sentirem discriminados e não associarem a obesidade ao emocional. Existem casos de pessoas que se submeteram a CBM e após o procedimento não continuaram o tratamento com estes profissionais por não entenderem que o tratamento não se destina apenas ao emagrecimento e correção de enfermidades físicas, mas ao equilíbrio entre corpo e mente, pois existem reações químicas envolvidas no processo que afetam o cérebro e o pensar. É necessário prevenir o aparecimento ou desenvolvimento da doença psíquica que se manifesta no corpo, pois é contagiosa podendo contaminar todos que estão ao redor da pessoa como família e amigos ${ }^{39}$.

Enfim, a preocupação da bioética com o cuidar e com o valorizar o indivíduo deve ultrapassar o orgânico, e abranger também o ser biopsicossocial e político como afirma Nascimento ${ }^{301}$ (p.136) "Mais do que um fato meramente orgânico, para nós humanos, a vida é um fato social e político. E a bioética se conecta com as diversas dimensões ao analisá-las, refleti-las e ajudar a tomar decisões em casos nos quais os conflitos morais em relação com a vida se instalam." 


\section{CONSIDERAÇÕES FINAIS}

A corporeidade é um tema bastante complexo. Ao observar à construção da imagem corporal a partir da estruturação da identidade individual e coletiva pode-se perceber que o desenvolvimento de uma sociedade está intimamente atrelado às influências de determinados grupos sociais. Analisar as opiniões, críticas, imposições e percepções sobre o corpo permite enxergar além da biologia, significa que o corpo possui simbologia, isto é pode significar poder, status, beleza, objeto de atração, admiração ou repulsa.

Para entender o estigma, a discriminação e a exclusão em relação às formas corpóreas diferentes da estética padrão é preciso mergulhar no mundo de quem sofre estes preconceitos para poder se aproximar o máximo possível dos conflitos externos e internos e também poder traçar o perfil do caráter social da dimensão individual e coletiva.

O corpo é uma ferramenta social de interação, de controle, de expressão, de linguagem e sentimentos, portador de significados e fonte de

sentidos. É a porta que permite contato com o mundo exterior concretizando a existência. No mundo globalizado a forma corpórea tem sido obrigada a possuir elementos que quando agregados transmitem ideia de bem-estar, são eles: saúde, estética e movimento, a sociedade relaciona o bem-estar unicamente aos aspectos físicos associados à sexualidade, sensualidade, beleza e sucesso.

Uma das maiores preocupações com o corpo nos dias atuais é a busca pela estética corporal perfeita e aceita, pois a impressão social transmitida por este corpo nas inter-relações é o filtro para a aceitação ou rejeição. Embora a sociedade afirme valorizar mais os aspectos subjetivos do indivíduo que os corporais, de forma velada transmitem uma insatisfação global com a imagem corporal do outro, principalmente em relação às silhuetas avantajadas que trazem desconforto social e descontentamento individual. Os corpos não padronizados trazem conflitos entre o real e o imaginário, forçando a adoção de 
pensamentos e comportamentos diversos com o objetivo de se enquadrar no perfil corporal padrão.

O corpo com obesidade mórbida tem sido rejeitado pela sociedade moderna, pois esta dissemina a ideia de que todo gordo é um desviado social e desleixado que possui um vazio em seu íntimo e que tenta preenche-lo com comida, mesmo que de forma equivocada. $O$ ato de comer de forma descontrolada é considerado por muitos como sinônimo de ansiedade, um descontentamento do Eu, como se algo estivesse faltando, porém não se sabe determinar exatamente o que é.

A cultura do excesso, da vida frenética, do consumismo e do individualismo tem desafiado a psique do homem. Tudo é muito urgente, e isto traz sofrimento psíquico e busca por tamponamentos destas lacunas internas que muitas vezes são preenchidos de forma ilusória. O alimento tem sido usado como escape para soluções de problemas emocionais, tendo como uma das consequências a obesidade. Não se pode negar que o simples ato de se alimentar possua diferentes significados: nutrição, saciedade, beleza, saúde, felicidade, gratificação, prazer, riqueza, compulsão, compensação, pobreza, doença e tristeza.

A obesidade mórbida representa para esta sociedade lipofóbica, um insulto, sinal de falta de vontade, fraqueza e baixa autoestima. $O$ culto ao corpo perfeito preconizado pela sociedade leva milhões de pessoas, atingindo todas as classes sociais e faixas etárias, a uma busca esquizofrênica por fórmulas dietéticas milagrosas, anorexígenos, academias e cirurgias plásticas, na tentativa de se enquadrar em um modelo corporal padrão, uma "cópia".

O preço pago para o alcance da silhueta afinada vai muito além da busca pela saúde. A busca pela perfeição corporal e o desejo de agradar 0 outro de modo a não sofrer preconceitos pode trazer benefícios, mas também transtornos permanentes devido a alterações morfofisiológicas. Desejar uma melhor qualidade de vida não é condenável, os cuidados com o corpo devem ser estimulados, contudo os limites da biologia e da genética deste corpo devem ser respeitados. 
O comportamento obsessivo por um corpo magro e a ideia de que o corpo é infinitamente maleável pode trazer consequências negativas e maléficas. Por isto a CBM não deve ser considerada e praticada como um procedimento estético corriqueiro, da mesma forma a obesidade mórbida não deve ser analisada somente como uma doença crônica e individual. Daí a importância da bioética como mediadora entre as críticas e possíveis soluções para o fenômeno obesidade.

A CBM é um procedimento que altera os estímulos sensoriais por interrupção das conexões fisioquímicas e modifica a estrutura corporal e a percepção do indivíduo em relação à própria imagem. É um procedimento capaz de equilibrar a relação do indivíduo, corpo e sociedade. $O$ desequilíbrio existe devido interferências intrínsecas e extrínsecas que traz uma instabilidade nesta relação que desperta sentimentos de insatisfação da imagem corporal estimulando a busca por possibilidades de reconstrução do corpo. O que responde o primeiro objetivo específico deste estudo que é mostrar que a CBM integra o estudo da corporeidade enquanto procedimento que modifica a imagem corporal e a percepção social em relação aos corpos resgatando a dignidade, a qualidade de vida do indivíduo e a aceitação social.

Os procedimentos em torno da CBM trazem à tona as contradições de um mundo globalizado em que a sociedade exige uma estética perfeita e ao mesmo tempo influencia o consumo desenfreado de alimentos, direcionado por meio da publicidade e propaganda, ditando o que deve ser consumido, quem deve consumir, quando e quanto consumir. $O$ marketing tem a principal função de aumentar a insatisfação e personificar o prazer em objetos, pessoas, produtos e serviços, e o marketing alimentício não está excluído desta estratégia. Esta exigência social sobre a estrutura e imagem corporal dos indivíduos desencadeia transtornos alimentares e comportamentais como anorexia, bulimia, vigorexia (também conhecida como Dismorfia Muscular e Anorexia Nervosa Reversa) e outros excessos associados à distorção da imagem corporal.

Os discursos do participante confirmam a existência de discursos impositivos por parte do outro, da sociedade capitalista. E ao mesmo tempo é 
possível observar o confronto dos discursos individuais e sociais, ao mesmo tempo que a sociedade exige um corpo magro, também permite ambientes e comportamentos que favorecem o desenvolvimento da obesidade, o que representa uma batalha entre discursos e conflitos na construção da imagem corporal e da identidade.

A preocupação com o tema obesidade mórbida tem aumentado devido ser doença incapacitante e motivo de exclusão social. A exclusão ocorre por dificuldade de mobilidade, discriminação e estigmatização. Nestes contextos em que a discriminação e estigmatização contra a pessoa humana estão presentes, a bioética obrigatoriamente deve se manifestar de forma a defender os indivíduos em situação de vulnerabilidade por meio da aplicação dos princípios da DUBDH que é um instrumento de apoio às leis e normas existentes, e também é uma ferramenta que pode ser utilizada na educação de base do indivíduo e da sociedade no sentido de compreender o processo da doença, as formas de tratamento, os direitos da pessoa obesa, análise da doença envolvendo a ética e a moral, também trabalhar a não-discriminação e não-estigmatização da pessoa com obesidade mórbida.

É necessário que os diálogos bioéticos sejam introduzidos nos ambientes educacionais, profissionais e sociais tendo como objetivo minimizar os agravos físicos, mentais e sociais sofrido pela pessoa obesa e a sociedade em geral. A bioética ainda é sim elitizada, ficando restrita as universidades, o que é lamentável diante de possibilidades de ambientes ociosos por conhecimento, empoderamento e libertação. Esta resistência da bioética em se expandir aos ambientes sociais mais populares ou menos favorecidos talvez seja pelo receio do não entendimento por parte dos ouvintes da linguagem e termos diferenciados. Os bioeticistas devem se preparar para disseminar os princípios das bioéticas em várias linguagens de acordo com o público-alvo, começar a fazer parte da realidade dos diálogos das minorias e dos vulneráveis. A bioética não deve ficar limitada a discursos e palestras em ambientes privilegiados.

A preocupação com a qualidade de vida da pessoa enquanto obeso e com os gastroplastizados deve ser potencialmente enfatizada nos ambientes 
bioéticos, a intervenção cirúrgica para combater a obesidade mórbida deve ser discutida como uma alternativa favorável em se tratando de sobrevida. As técnicas estão sendo aprimoradas a cada dia, contudo, a bioética e a ética devem estar envolvidas para trazer maior segurança, confiança e respeito à pessoa obesa e orientar os pesquisadores, estudiosos e outros interessados pelo tema sobre quais caminhos seguir. É importante esclarecer que a obesidade não deve ser vista somente como uma doença, mas como uma consequência de uma sociedade capitalista que apresenta distorções comportamentais graves.

A obesidade e a CBM devem ser temas constantes nos diálogos bioéticos, principalmente em relação aos determinantes sociais e ambientais que favorecem 0 desenvolvimento da obesidade e não pautar somente 0 resultado final, não basta discutir somente o procedimento CBM, mas o que gera a busca por este procedimento e quais as causas da obesidade mórbida. Os bioeticistas devem monitorar as novas tecnologias em saúde e defender as que trazem benefícios, longevidade, redução de morbidades e mortalidades, sempre com prudência. Trazer esclarecimentos e discussões sobre educação ética alimentar e suas consequências diante de uma má escolha. Devem se envolver nas questões de informações publicitárias de produtos alimentícios e também em questões econômicas que envolvem preços acessíveis para alimentos saudáveis e orgânicos e implantação de práticas comportamentais que previnam a obesidade mórbida.

A obesidade mórbida deve ser discutida de forma mais aberta e ampla, assim como à ideia de "estigmatização light" defendida por Callahan. Existem raros diálogos sobre esta estratégia, no Brasil principalmente, o que gera inúmeras perguntas ainda sem respostas, já que foi praticada e teve resultados positivos na saúde pública em diversos países quando utilizada nas campanhas antitabagismo, exemplo de "estigmatização light". A sociedade organizada deve ser informada e ouvida, os bioeticistas devem pulverizar estas informações e organizar debates para avaliar e identificar possíveis soluções.

A CBM deve ser vista também como um procedimento auxiliador no combate a discriminação e estigmatização, o que reforça a ideia de obesidade 
como doença decorrente de ambientes e fenômenos sociais estressantes, o que exige estratégias mais rígidas para controlar esta epidemia, porém não discriminatórias, como por exemplo, aumentar o valor dos tributos (impostos, taxas e contribuições) dos produtos industrializados obesogênicos, como forma de punição às indústrias e estímulo a modificar a produção. Contudo, pensar na autonomia de escolha, não obrigando, não punindo, não criticando, e sim orientando sobre as consequências das melhores e piores escolhas.

Os Estados já praticam o controle do que a população pode ou não consumir, desde alimentos até produtos eletrônicos, para isto existe leis ambientais e industriais. Exemplo são as que regulam a agricultura e pecuária por meio do Ministério da Agricultura, Pecuária e Abastecimento e Departamento de Inspeção de Produtos de Origem Vegetal.

Existem alimentos que são proibidos a venda por serem ilícitos ou crime ambiental, outros podem até ser vendidos, mas pela escassez, raridade ou alto custo de produção possuem um valor elevado, ficando restrito a uma pequena parte da população. O que diferencia o acesso aos bens e serviços lícitos são os valores comercializados, quem tem poder aquisitivo elevado pode consumir todos os produtos e alimentos, incluindo os mais saudáveis, como os diet, light e orgânicos. Os Estados devem se comprometer mais com seus cidadãos e com a qualidade de vida e bem-estar destes do que com as indústrias que tem o pensamento voltado somente para o mercantilismo.

Por meio da educação e informação o consumidor pode avaliar as opções e decidir na hora da compra o que é mais saudável, tendo a consciência do que é benéfico ou maléfico para sua saúde. Entre outras recomendações, destacam-se as instituições educacionais que devem remover barreiras arquitetônicas e sociais resguardando os princípios dos direitos humanos. Permitindo o recrutamento de profissionais que estão acima do peso nas instituições de ensino, desde que comprovadas às habilidades, isto tem finalidade de promover o acesso a informação, educação e inclusão social e profissional, além de permitir a participação destes em fóruns e congressos nacionais e internacionais. 
Também é um meio de inibir atos de preconceitos, pois a discriminação social e interações sociais negativas influenciam em questões psicológicas e pioram o quadro de obesidade. Quando as habilidades funcionais diárias são reduzidas por causa do peso corporal, como subir escadas, caminhar, entre outros, estas experiências são internalizadas gerando estresse e ansiedade, podendo causar compulsão alimentar e prejudicando a saúde. O estigma da obesidade tem relação direta com a auto percepção de saúde, incapacidade funcional e aumento dos riscos de doenças relacionadas à obesidade.

A pessoa com obesidade mórbida deve ser inserida e consultada nos assuntos referentes às políticas específicas, deixando de ser meros ouvintes e em muitos casos de serem extremamente "protegidas". Muitos grupos excluídos têm sido proibidos de emitir suas escolhas e exercer sua autonomia em nome desta "proteção". A bioética deve trabalhar no sentido de reabilitar estas pessoas por meio do empoderamento para que possam se comunicar e fazer suas escolhas. Assim as diversas barreiras enfrentadas poderão ser transpassadas e a equidade e universalidade alcançadas, eliminando a discriminação e praticando a inclusão.

A educação social sobre não-discriminação e não-estigmatização necessita muito mais que boa vontade, inclui compromisso e responsabilidade social, política e econômica. Deve-se garantir acesso igualitário por meio de ambientes inclusivos com adaptações que eliminem ou minimizem as diferenças, principalmente em sala de aula. As instituições educacionais necessitam de professores especializados com assistentes habilitados e treinados.

É impossível falar em igualdade, não-discriminação, não-estigmatização, justiça e responsabilidade social, quando no próprio "mundo" acadêmico existe a exclusão de pessoas obesas por inúmeros motivos, por professores não capacitados, ambientes não adaptados (mesas, cadeiras, banheiros...), ausência de psicólogos para trabalhar o emocional, falta de livros e outros materiais didáticos que abordem o tema. Em um mundo globalizado é incoerente ainda ter instituições educacionais não adaptadas, pois são meios de comunicação, transformação e inclusão social. Está na hora da bioética se 
dispor a participar de eventos fora da academia e adentrar em comunidades não elitizadas, em hospitais, em escolas e usar uma linguagem mais acessível, até mesmo revistas ou livros didáticos com figuras ilustrativas com temas do dia a dia e casos clínicos para debates, está na hora dos profissionais de saúde praticarem a bioética a beira do leito, nos consultórios, nas palestras ambulatoriais.

A inclusão social depois do ambiente familiar deve ser reforçada no ambiente escolar e perpassar por todos os níveis (fundamental, médio e superior) e os professores devem acompanhar as mudanças, além de estimular iniciativas e participar das experiências inclusivas. Os países não podem mais negligenciar milhares de pessoas com obesidade mórbida, sendo privadas da educação, da saúde, do emprego, da reabilitação. Sendo negados todos os seus direitos e oportunidades de se desenvolverem e mostrar suas habilidades.

Parece ser óbvio que todas as pessoas independente de ter ou não alguma limitação tenha direito à educação, sendo este um direito fundamental e indispensável para a prática da cidadania. A Constituição Federal de 1988 no caput do artigo $5^{\circ}$ deixa claro que todos são iguais perante a lei, reforçando os princípios da igualdade e da justiça, compreendendo que a justiça deve observar e tratar os iguais de forma igual e os desiguais de forma desigual respeitando assim o princípio da equidade. Não basta apenas a legislação obrigar a inclusão nas instituições educacionais por meio de cotas e matrículas, o ambiente deve ser preparado para a socialização e aceitação dos diferentes. Mas a prática por meio de observações e relatos demonstra a privação deste direito e a luta dos excluídos por condições iguais na vida em sociedade de acordo com suas necessidades.

A bioética por meio da DUBDH e seu artigo 11 desperta para uma avaliação sobre como inserir a pessoa considerada diferente e com necessidades específicas no contexto dos debates bioéticos, não somente como uma pessoa vulnerável que precisa ser defendida e protegida, mas como um cidadão capaz de compreender e participar dos diálogos bioéticos. Contudo os caminhos percorridos até o momento tem apresentado uma participação reduzida destas pessoas devido à ausência de estratégias e ferramentas que 
auxiliem a inclusão deste segmento. Este trabalho mostra diferentes alternativas ou caminhos para facilitar o entendimento do tema bioética, de forma a permitir a inclusão da pessoa com obesidade mórbida, isto é, torná-las visíveis, ultrapassar as barreiras do preconceito e incentivar a prática da nãodiscriminação e não-estigmatização. Pois, a dignidade por mais que os estudiosos digam que não é algo palpável, ela se torna real e dolorosa para a pessoa que sofre pela ausência da mesma.

Os princípios da DUBDH provoca esta ação de inclusão na vida social e acadêmica, pois a própria bioética em sua essência tem por objetivos combater a pobreza, o preconceito, a discriminação, a estigmatização, a injustiça, as desigualdades sociais e a exclusão dos diferentes e vulneráveis. Ações devem ser adotadas e implantadas para minimizar o preconceito entre os obesos e não obesos. Partindo do pensamento de que quando os investimentos são insuficientes na qualidade de vida da pessoa obesa, os gastos na saúde triplicam, o rendimento escolar é inferior em relação aos que possuem peso normal e poder aquisitivo superior. Os bioeticistas devem se mobilizar com o objetivo de montar estratégias de sensibilização da sociedade e capacitação de profissionais para este fim.

O artigo $4^{\circ}$ da DUBDH não deve ser esquecido, pois os danos e benefícios em decorrência da CBM ainda estão sendo pesquisados, contudo diante das complicações da doença na vida do obeso mórbido que podem levar a morte, a CBM se torna uma ferramenta fundamental relacionada ao riscobenefício. Os riscos durante e após o procedimento existem, por isto, é fundamental uma avaliação e seleção criteriosa do paciente e o preparo deste pela equipe multidisciplinar e também a escolha da melhor técnica cirúrgica para cada indivíduo. Reforçar o acompanhamento ao longo do processo é importante, principalmente no primeiro ano pós CBM. Estas reflexões sobre bioética e educação reforçam o segundo objetivo específico proposto, corroborando que a DUBDH é uma ferramenta de auxílio educacional e institucional para tentar resolver conflitos em torno da pessoa com obesidade mórbida, assim bem como despertar discussões sobre os princípios do 
Benefício e Dano e Não-discriminação e Não-estigmatização em torno da CBM e da pessoa obesa.

O que este estudo trouxe de mais importante em uma visão humanística foi o despertar das reflexões sobre os discursos dos participantes que estão recheados de significados em relação ao corpo obeso como insatisfações, a negação do corpo, o desejo de alteração corporal, o afloramento de sentimentos negativos e positivos como a tristeza, o isolamento, a dor, a felicidade. Por meio da análise dos dados foi possível compreender como a imagem corporal e a autoestima estão relacionadas aos comportamentos individuais e coletivos. Pensar na obesidade mórbida não somente como uma doença, mas como uma causa de isolamento e rejeição em uma sociedade que exclui qualquer forma diferente de uma estética socializada é um tema bastante polêmico e indicador de abordagem bioética. Os relatos e dados neste estudo reforçam a existência da discriminação e estigmatização em relação à imagem corporal obesa e que estas influenciam na busca pelo procedimento de CBM contemplando assim o terceiro objetivo proposto.

O sofrimento moral vivenciado pelo corpo obeso devido à discriminação relaciona-se diretamente ao grau de obesidade, quanto maior o IMC mais problemas psicológicos estão presentes. Desta forma, além de carregar o peso de seu corpo, o corpo obeso leva consigo o peso da culpa e da responsabilidade por sua obesidade. Pode-se perceber o quanto a pessoa com obesidade mórbida é carente emocionalmente e principalmente carente de informações sobre a doença e direitos, daí a necessidade de uma abordagem multidisciplinar e educadora para abrir novos caminhos na temática corporeidade, bioética, obesidade mórbida, CBM e os preconceitos que cercam a temática.

Este quadro de busca da saúde e da dignidade por meio da CBM deixa clara a necessidade e a importância do uso da DUBDH como ferramenta consultiva e educativa nas questões que envolvem a vida e a melhora da qualidade de vida. Um dos principais objetivos da bioética é a busca por uma melhor qualidade de vida que está intimamente associada com a dignidade humana. As leis devem promover e assegurar o direito à igualdade de acesso, 
de liberdade, inclusão social e cidadania, deve estimular a não-discriminação, a não-negligência, não exploração, não violência, não tortura, não crueldade, não opressão e desaprovar qualquer tratamento desumano ou degradante. As políticas públicas devem contemplar ações destinadas às pessoas obesas inclusive diagnósticos e intervenções precoces realizados por equipe multidisciplinar que assegurem a habilitação e reabilitação para garantir a manutenção da condição de saúde e qualidade de vida.

Espera-se que 0 presente estudo possa contribuir para estimular discussões bioéticas sobre o tema obesidade mórbida e CBM. Despertar a ideia de que a perda ponderal não é o único benefício decorrente da CBM, mas também a redução da morbimortalidade, aumento da longevidade, melhoria na qualidade de vida, eliminação de preconceitos, discriminação e estigmas. 


\section{REFERÊNCIAS}

1. Schilder NEM, Secoli SRS, Nobre MRC, Ono-Nita SK, Campino ACC, Santi FM, Costa AMN, Carrilho FJ. Avaliação de tecnologias em saúde: evidencia clínica, análise econômica e análise de decisão. Porto Alegre: Artmed, 2010.

2. Leite MA, Valente DC. Tratamento cirúrgico da obesidade mórbida: indicações, seleção e preparo dos pacientes. [online]. Colégio Brasileiro de Cirurgiões, Rio de Janeiro, v. 2, n. 3, 2003. Disponível em:< http://cbc.org.br/wp-content/uploads/2013/05/Ano2-III.Obesidade-morbida.pdf>. Acesso em: 12 Fev. 2012.

3. Declaração Universal sobre Bioética e Direitos Humanos da UNESCO. Paris, 2005. [online]. Disponível em:< http://www.sbbioetica.org.br/dubdh/>. Acesso em: 18 Set. 2012.

4. Tavares MCGC. Imagem corporal: conceito e desenvolvimento. São Paulo: Manole, 2003.

5. Rosário NM. Mundo contemporâneo: corpo em metamorphose. [versão online 2006]. Disponível [online] em: < http://www.comunica.unisinos.br/semiotica/nisia_semiotica/conteudos/corpo.ht m>. Acesso em: 14 Jun. 2014.

6. Fandiño J, Benchimol AK, Coutinho WF, Appolinário JC. Cirurgia Bariátrica: aspectos clínico-cirurgicos e psiqiátricos. [online]. Revista de Psiquiatria, Rio Grande do Sul, v. 26, n. 1, 2004. Disponível em: <http://www.scielo.br/pdf/rprs/v26n1/20476.pdf>. Acesso em: 22 Mar. 2011.

7. Associação Médica Brasileira. Comissão de prevenção e tratamento da obesidade. Revista Eletrônica. 2012 [online]. Disponível em:<http://obesidadenobrasil.com.br/maleficios/>. Acesso em: 26 Jul. 2012.

8. Brasil. Ministério da Saúde. Secretaria de Vigilância em Saúde. Departamento de Vigilância de Doenças e Agravos não Transmissíveis e Promoção da Saúde. Vigitel Brasil 2014 : vigilância de fatores de risco e proteção para doenças crônicas por inquérito telefônico / Ministério da Saúde, Secretaria de Vigilância em Saúde, Departamento de Vigilância de Doenças e Agravos não Transmissíveis e Promoção da Saúde. - Brasília : Ministério da Saúde, 2015.2 Disponível [online] em:<http://bvsms.saude.gov.br/bvs/publicacoes/vigitel_brasil_2014.pdf>. Acesso em: 15 Out. 2015.

9. Conselho Federal de Medicina. Resolução CFM No 1.942 de Fevereiro de 2010. (Publicada no D.O.U. de 12 de fevereiro de 2010, Seção I, p. 72). Disponível [online] em:< http://www.institutogarrido.com.br/pdf/resolucao_cfm_1766_05.pdf >. Acesso em: 22 Ago. 2012. 
10 Sociedade brasileira de cirurgia bariátrica e metabólica. Técnicas Cirúrgicas, 2011. Disponível [online] em:< http://www.sbcb.org.br/cbariatrica.asp?menu=2>. Acesso em: 28 fev. 2012.

11. Cintra DE, Ropelle ER, Pauli JR. Obesidade e diabetes - fisiopatologia e sinalização celular. São Paulo: Sarvier, 2011.

12. Le Breton D. A Sociologia do Corpo. Petrópolis, RJ: Vozes, 2006.

13. Csordas T. Corpo/significado/cura. Tradução de José Secundino da Fonseca e Ethon Secundino da Fonseca. Porto Alegre: Editora da UFRGS, 2008.

14. Schilder P. A Imagem do Corpo: As Energias Construtivas da Psique. São Paulo: Martins Fontes, 1999.

15. Pessanha JAM. Platão. Diálogos (O Banquete, Fédon, Sofista, Político). Seleção de textos de José Américo Motta Pessanha; tradução e notas de José Cavalcante de Souza, Jorge Paleikat e João Cruz Costa. 4a. Edição. São Paulo: Nova Cultural, 1987, (Os pensadores).

16. Schultz DP, Schultz ES. História da Psicologia Moderna. Tradução Suely Sonoe Murai Cuccio. - São Paulo: Cengage Learning, 2009.

17. Descartes R. Discurso do método: para bem conduzir a própria razão e procurar a verdade nas ciências. São Paulo: Paulus, 2002.

18. Abbagnano N. Dicionário de filosofia. 2.ed. São Paulo: Mestre Jou, 1982.

19. Debrod G. A sociedade do espetáculo. Rio de Janeiro: Contra ponto Editora, 1997.

20. Gil J. Metamorfoses do corpo. Lisboa: Relógio d'água, 1997.

21. Lacan, J. (1998a). O estádio do espelho como formador da função do eu. In Escritos (pp. 96-103). Rio de Janeiro: Jorge Zahar.

22. Freud S. O estranho (1919). Edição Standard Brasileira das Obras Psicológicas Completas, v.17. Rio de Janeiro: Imago, 1976.

23. Freud S. Introdução ao Narcisismo, Ensaios de Metapsicologia e Outros Textos (1914-1916) - Coleção Obras Completas - Vol. 12. Companhia das Letras 2010.

24. Brandão JS. O Mito de Narciso e Eco. Mitologia grega. Vol. 3Rio de Janeiro: Vozes, 1989.

25. Lacan J. (1962-63) O seminário, livro 10: a angústia. Rio de Janeiro: Jorge Zahar, 2005.

26. Freud S. Além do princípio do prazer. Edição Standard Brasileira das Obras Psicológicas Completas, v.18. Rio de Janeiro: Imago, 1976. 
27. Mauss M. As técnicas do corpo. Extraído do joumal de Psychologie. Vol. 2, no. 3-4, 193. Comunicação apresentada à Sociedade de Psicologia em 17 de maio de 1934 . Disponível [online] em:< https://monoskop.org/images/b/bb/Mauss_Marcel_1935_2003_As_tecnicas_do corpo.pdf>. Acesso em: 14 Abr. 2015.

28. Foucault M. Microfísica do poder. Rio de Janeiro: Graal, 1992.

29. Foucault M. História da sexualidade I: a vontade de saber. 17.ed. Rio de Janeiro: Edições Graal, 1984.

30. Porto D. Bioética e qualidade de vida. As bases da pirâmide social no coração do Brasil: Um estudo sobre a qualidade de vida, qualidade de saúde e qualidade de atenção à saúde de mulheres negras no Distrito Federal. Tese de Doutorado, 2006.2 Disponível [online] em: <http://repositorio.unb.br/bitstream/10482/5677/1/2006-

Dora\%20de\%20Oliveira\%20e\%20Silva\%20Porto.pdf>. Acesso em: 22 Jun. 2015.

31. Givens D. A linguagem corporal no trabalho, Vozes, Petrópolis 2011.

32. Weil P, Tompakow R. O Corpo fala. A linguagem silenciosa da comunicação não-verbal. Vozes, Petrópolis 2012.

33. Freire G, Salgado Ml. Saúde e Espiritualidade - uma nova visão da medicina. Livro 1. Belo Horizonte: Inede, 2008.

34. Borges DC, Anjos GL, Oliveira LR, Leite JR, Lucchetti G. Saúde, espiritualidade e religiosidade na visão dos estudantes de medicina. Rev Bras Clin Med. São Paulo, 2013 jan-mar;11(1):6-11. Disponível [online] em:<http://files.bvs.br/upload/S/1679-/2013/v11n1/a3380.pdf>. Acesso em: 12 Mar.2016.

35. World Health Organization. Division of mental health and prevention of substance abuse. WHOQOL and spirituality, religiousness and personal beliefs (SRPB). Genève: $1998 . \quad$ Disponível [online] em:< http://apps.who.int/iris/bitstream/10665/70897/1/WHO_MSA_MHP_98.2_eng.pd $f>$. Acessoe em: 12 Mar. 2016.

36. Ross L. The Spiritual Dimension: Its Importance to Patients' Health, WellBeing and Quality of Life and its Implication for Nursing practice. International Journal of Nursing Studies, 1995: 32(5): 457-468. Disponível [online] em:<http://www.ncbi.nlm.nih.gov/pubmed/8550306>. Acesso em: 22 Mar. 2016.

37. Freire G, Salgado Ml. Saúde e Espiritualidade - uma nova visão da medicina. Livro 1. Belo Horizonte: Inede, 2008.

38. Vilosh VM, Ranña W, Labaki MEP. (Orgs). Psicossoma V: integração, desintegração e limites. São Paulo: Casa do Psicólogo, 2014.

39. Carvajal J. Qual adoece primeiro: o corpo ou a alma?. Entrevista com Dr. Jorge Carvajal, médico colombiano, cirurgião da Universidade de Andaluzia, 
Espanha, pioneiro da Medicina Bioenergética. Disponível [online] em:< http://ciclofemini.com.br/para-ler-e-pensar/qual-adoece-primeiro-o-corpo-ou-aalma-por-dr-jorge-carvajal/ >. Acesso em: 14 Mar. 2016.

40. Brasil. Ministério da Saúde. Secretaria de Atenção à Saúde. Departamento de Atenção Básica. Obesidade / Ministério da Saúde, Secretaria de Atenção à Saúde, Departamento de Atenção Básica. - Brasília: Ministério da Saúde, 2006. Disponível [online]

em: $<$ http://dab.saude.gov.br/portaldab/biblioteca.php?conteudo=publicacoes/cab12 >. Acesso em: 23 Out. 2013.

41. Garrido JAB. Situações especiais: tratamento da obesidade mórbida. In: Halpern A, Matos AFG, Suplicy HL, Mancini MC, Zanella MT, editores. Obesidade. São Paulo: Lemos Editorial; 2002.

42. Segal A, Fandiño J. Indicações e contra-indicações para realização das operações bariátricas. Revista Brasileira de Psiquiatria, v. 24, n. 3, São Paulo, 2002, p.68-72. Disponível [online] em:<http://www.abeso.org.br/uploads/downloads/25/552ff02fcc75f.pdf>. Acesso em: 07 Set. 2012.

43. Fioravanti C, Zorzetto R. Dieta de alto risco: responsável pelo ganho de peso, bloqueio à insulina começa no cérebro e aumenta predisposição às doenças cardiovasculares e ao câncer. Revista Pesquisa Fapesp.n. 140, p.4044, out. 2007. Disponível [online] em:<http://revistapesquisa.fapesp.br/wpcontent/uploads/2007/10/40-44_Dieta-capa_140.pdf?3414f4>. Acesso em: 07 Set. 2012.

44. Freud S. Estudos sobre a Histeria (1893-1895) - Coleção Obras Psicológicas Completas de Sigmund Freud - Vol. 2 Imago, 2006a.

45. Freud S. A história da sexualidade: A vontade de saber. São Paulo: Graal, 2006b.

46. Berg R. Medicina, Freud e obesidade: diálogos multidisciplinares sob a perspectiva de Foucault. Rio de Janeiro: Ágora, 2011, vol.14, n.2, pp. 183-196. Disponível em:<http://www.scielo.br/scielo.php?script=sci_arttext\&pid=S1516-

[online] 14982011000200002>. Acesso em: 15 Mai. 2013.

47. Caio Junior JS, Caio HV. Gordura visceral. Artigo de Jun. 2011. Disponível [online] em: <http://gorduravisceral.wordpress.com/2011/06/13/endocrinologianeuroendocrinologia-obesidade-sobrepeso-obesidade-obesidade-centralabdominal-intra-abdominal-visceral-intra-visceral-sindrome-metabolicapreconceito-e-estigmatizacao-dos-ob/>. Acesso em 26 Ago. 2012.

48. World Health Organization. Division of Noncommunicable Diseases. Programme of Nutrition Family and Reproductive Health. Obesity: preventing and managing the global epidemic: report of a WHO consultation on obesity. 
Geneva: WHO; $1998 . \quad$ Disponível [online] em: <http://www.ncbi.nlm.nih.gov/pubmed/11234459>. Acesso em: 14 Mai. 2012.

49. Puglia $C R$. Indicações para o tratamento operatório da obesidade mórbida. Rev. Assoc. Med. Bras. 2004, vol.50, n.2, pp. 118-118. ISSN 0104-4230. Disponível [online] em:<http://www.scielo.br/pdf/ramb/v50n2/20761.pdf>. Acesso em: 21 Mai. 2012.

50. Stunkard AJ, Sorensen TI, Hanis C, Teasdale TW, Chakraborty R, Schull WJ, Schulsinger F. An adoption study of human obesity. N Engl J Med 1986; 314. Disponível [online] em: <http://www.ncbi.nlm.nih.gov/pubmed/3941707>. Acesso em 26 Ago. 2012.

51. Associação brasileira para o estudo da obesidade e síndrome metabólica. Diretrizes brasileiras de obesidade. $3^{\circ}$ ed. 2009/2010. Itapevi, SP : AC Farmacêutica, 2009. [online] em:< http://www.abeso.org.br/pdf/diretrizes_brasileiras_obesidade_2009_2010_1.pdf >. Acesso em: 17 Jun. 2014.

52. Carneiro JRI, Kushnir MC, Clemente ELS, Brandão MG, Gomes MB. Obesidade na Adolescência: Fator de Risco para Complicações ClínicoMetabólicas. Arq. Bras. Endocrinol Metab. Vol 44 no 5 Out. 200. Disponível [online] em:<http://www.scielo.br/pdf/abem/v44n5/10627.pdf>. Acesso em: 11 Jun. 2012.

53. Brasil. Lei o 13.146, de 06 Julho de 2015. Institui a Lei Brasileira de Inclusão da Pessoa com Deficiência (Estatuto da Pessoa com Deficiência). Presidência da República. Casa Civil. Subchefia para Assuntos Jurídicos. Brasília, 2015. Disponível [online] em:< http://www.planalto.gov.br/ccivil_03/_Ato2015-2018/2015/Lei/L13146.htm>.

Acesso em: 22 Ago. 2015.

54. Etcoff N. A verdade sobre a beleza: um relatório global. Descobertas de um estudo global sobre mulheres, beleza e bem-estar. Relatório para Dove. 2004. Disponível [online] em: <http://www.realbeleza.com.br>. Acesso em: 13 Dez. 2013.

55. Bourdieu P, Kühner MH. A dominação masculina. $3^{\circ}$. ed. Rio de Janeiro: Bertrand Brasil, 2003.

56. Martins S. O peso da mente feminina: associação entre obesidade e depressão. Rev Port Med Geral Fam 2012; 28:163-6. Disponível [online] em:<http://www.apmgf.pt/ficheiros/rpmgf/v28n3a01/v28n3a04.pdf>. Acesso em: 22 Ago. 2013.

57. Pêgo-Fernandes PM; Bibas BJ; Deboni M. Obesity: the greatest epidemic of the 21st century? Sao Paulo Med J. 2011;129(5):283-4. Disponível [online] em: $<$ http://www.scielo.br/scielo.php?pid=S1516-

31802011000500001\&script=sci_arttext>. Acesso em: 12 Abr. 2015. 
58. Instituto Brasileiro de Geografia e Estatística. Pesquisa de Orçamentos Familiares - POF 2008/2009. Rio de Janeiro. Disponível [online] em:<www.ibge.gov.br/populacao/condicaodevida/pof/2008_2009_encaa/default /shtm>. Acesso em 15 Jul. 2012.

59. Brasil. Ministério da Saúde. Secretaria de Vigilância em Saúde. Vigitel Brasil 2013: vigilância de fatores de risco e proteção para doenças crônicas por inquérito telefônico / Ministério da Saúde, Secretaria de Vigilância em Saúde. Brasília: Ministério da Saúde, 2014. Disponível [online] em: $<$ https://biavati.files.wordpress.com/2014/05/vigitel-2013.pdf>. Acesso em 15 Fev. 2015.

60. Marie NG, Fleming T, Robinson M, Thomson B, Graetz N, Margono C et al. Global, regional, and national prevalence of overweight and obesity in children and adults during 1980-2013: a systematic analysis for the Global Burden of Disease Study 2013. Publicado em: 28 Mai. 2014. Disponível [online] em: $<$ http://www.thelancet.com/journals/lancet/article/PIIS0140-6736(14)604608/abstract>. Acesso em 15 Fev. 2015.

61. Medeiros M, Galeno A. Olhares sobre a alimentação contemporânea: a gastro-anomia e os corpos de Botero. Rev. Nutr. 2013. Disponível [online] em: $<$ http://www.scielo.br/scielo.php?pid=S1415-

52732013000400008\&script=sci_arttext>. Acesso em: 15 Dez. 2012.

62. Olinda C. Índice de obesidade no Brasil aumenta 54\% em seis anos. Jornal Gazeta do Povo. Publicado em 28/08/2013. Disponível [online] em: $<$ http://www.gazetadopovo.com.br/vidaecidadania/conteudo.phtml?id=1403478 >. Acesso em: 12 Abr. 2013.

63. Priore MD. Corpo a corpo com a mulher - história das transformações do corpo feminino no Brasil, São Paulo, Senac, 2002.

64. Revista Exame. FAO convoca mundo a combater desperdício de alimentos. Publicado em13/06/2012. Disponível [online] em:<http://exame.abril.com.br/mundo/noticias/fao-convoca-mundo-a-combaterdesperdicio-de-alimentos>. Acesso em: 12 Abr. 2013.

65. Organização das Nações Unidas para a Alimentação e a Agricultura. Quase 870 milhões de pessoas no mundo estão subnutridas - novo relatório sobre a fome. Roma, 9 de outubro de 2012. Disponível [online] em:<https://www.fao.org.br/q870mpmesnrsf.asp>. Acesso em: 22 Jun. 2013.

66. Prentice AM, Jebb SA. Obesity in Britain: Gluttony or sloth? BMJ 1995;311:437-9. Disponível [online] em:<http://www.ncbi.nlm.nih.gov/pubmed/7640595>. Acesso em: 14 Jun. 2012.

67. Reis L. Refrigerante e doce provocam epidemia de diabetes em índios em MT. Folha de São Paulo. Publicado em: 09/08/2015. Disponível [online] em:< http://www1.folha.uol.com.br/cotidiano/2015/08/1666360-xavantes-trocamdieta-tradicional-por-refrigerante-e-pao-de-forma-no-mt.shtml>. Acesso em: 14 Dez. 2015. 
68. Sichieri R, Coitinho DC, Leão MM, E Recine, E Everhart. High temporal, geographic, and income variation in body mass índex among adults in Brazil. Am J Pub Health;84:793-8. 1994. Disponível [online] em:<http://www.ncbi.nlm.nih.gov/pmc/articles/PMC1615023/. Acesso em: 14 Jun. 2012.

69. Brasil. Ministério da Saúde. Secretaria de Atenção à Saúde. Departamento de Atenção Básica. Obesidade / Ministério da Saúde, Secretaria de Atenção à Saúde, Departamento de Atenção Básica. - Brasília: Ministério da Saúde, 2006. Disponível [online]

em: $<$ http://dab.saude.gov.br/portaldab/biblioteca.php?conteudo=publicacoes/cab12 >. Acesso em: 23 Out. 2013.

70. Gigante DP, Moura EC, Sardinha LMV. Prevalência de excesso de peso e obesidade e fatores associados, Brasil, 2006. Rev Saúde Pública 2009;43(Supl 2):83-9. Disponível [online] em: < http://www.scielo.br/pdf/rsp/v43s2/ao788.pdf>. Acesso em: 23 Out. 2013.

71. Brasil. Ministério da Saúde. Secretaria de Vigilância em Saúde. Vigitel Brasil 2011: Vigilância de Fatores de Risco e Proteção para Doenças Crônicas por Inquérito Telefônico. Ministério da Saúde, Secretaria de Vigilância em Saúde - Brasília: Ministério da Saúde, 2012. Disponível [online] em: < http://bvsms.saude.gov.br/bvs/publicacoes/vigitel_brasil_2011_fatores_risco_do encas_cronicas.pdf>. Acesso em: 16 Dez. 2013.

72 Vigitel Brasil 2012 - Vigilância de Fatores de Risco e Proteção para Doenças Crônicas por Inquérito Telefônico. Disponível [online] em: $<$ http://portalsaude.saude.gov.br/

portalsaude/arquivos/pdf/2013/Nov/26/Relatorios_Vigitel_2012.pdf>. Acesso em: 02 Dez. 2013

73. Brasil. Ministério da Saúde. Secretaria de Vigilância em Saúde. Departamento de Vigilância de Doenças e Agravos não Transmissíveis e Promoção da Saúde. Vigitel Brasil 2014: vigilância de fatores de risco e proteção para doenças crônicas por inquérito telefônico / Ministério da Saúde, Secretaria de Vigilância em Saúde, Departamento de Vigilância de Doenças e Agravos não Transmissíveis e Promoção da Saúde. - Brasília : Ministério da Saúde, 2015.2 Disponível [online] em:<http://bvsms.saude.gov.br/bvs/publicacoes/vigitel_brasil_2014.pdf>.

Acesso em: 15 Out. 2015.

74. Oliveira IV. Cirurgia bariátrica no âmbito do sistema único de saúde: tendências, custos e complicações. UnB, Brasília, 2007. Disponível [online] em:<http://nutricao.saude.gov.br/docs/boletimSisvan/dissertacao_final_291107. pdf>. Acesso em: 22 Jun. 2013.

75. World Health Organization. Obesity and overweight fact sheet no 311, March 2013. Acessado em 23 de novembro de 2013. Disponível [online] em:< http://www.who.int/mediacentre/factsheets/fs311/en/>. Acesso em: 22 Jun. 2014. 
76. Barros F. Qual o maior problema de saúde pública: a obesidade mórbida ou a cirurgia bariátrica no Sistema Único de Saúde?. Disponível [online] em:<Rev. Col. Bras. Cir. 2015; 42(2): 069>. Acesso em: 05 Abr. 2016.

77. Brasil. Ministério da Saúde. Portaria no 425 de 19 de março de 2013. Estabelece regulamento técnico, normas e critérios para o serviço de assistência de alta complexidade ao indivíduo com obesidade. Diário Oficial da União oㅜ 71, seção 1, p. 59, em 15/04/2013. Disponível [online] em: <http://bvsms.saude.gov.br/bvs/saudelegis/gm/2013/prt0425_19_03_2013.html >. Acesso em: 22 Set. 2012.

78. Rito RVVF. Obesidade e gravidez: mulheres obesas e seus hábitos alimentares durante a gravidez. 2004. Dissertação (Mestrado em Saúde da Mulher e da Criança)-Instituto Fernandes Figueira, Fundação Oswaldo Cruz, Rio de Janeiro, 2004.2 Disponível [online] em: <http://feb.ufrgs.br/feb/objetos/1109493>. Acesso em: 16 Ago. 2012.

79. Zilberstein B, Ferreira JA, Carvalho MH, Bussons C; Silveira-Filho AS; Joaquim H; Ramos F. Operação de Scopinaro modificado na falha da banda gástrica. ABCD Arq Bras Cir Dig. 2011;24(2):136-9. Disponível [online] em: <http://www.scielo.br/scielo.php?script=sci_arttext\&pid=S0102-

67202011000200009>. Acesso em: 11 Mai. 2013.

80. Mancini MC. Noções Fundamentais - Diagnóstico e Classificação da Obesidade. In: Garrido JAB, Ferraz EM, Barroso FL, et al. Cirurgia da Obesidade. $2^{\mathrm{a}}$ ed. São Paulo: Atheneu; 2006.

81. Hydock CM. A Brief overview of bariatric surgical procedures currently being used to treat the obese patients. Critical Care Nursing Quarterly. 2005; 28(5):217-26. Disponível [online] em: <http://www.ncbi.nlm.nih.gov/pubmed/16041223>. Acesso em: 12 Abr. 2014.

82. Zeve JLM, Novais PO, Oliveira Júnior N. Técnicas em cirurgia bariátrica: uma revisão da literatura. Revista Ciência \& Saúde, Porto Alegre, v. 5, n. 2, p. 132-140, jul./dez. 2012. Disponível [online] em: <http://revistaseletronicas. pucrs.br/ojs/index.php/faenfi/article/viewFile/10966/8 206>.Acesso em:13 Ago.2014.

83. Dâmaso A, Tock L. Obesidade - perguntas e respostas. Rio de Janeiro: Guanabara Koogan; 2005.

84. Sociedade Brasileira de Cirurgia Bariátrica e Metabólica. Cirurgia bariátrica e metabólica: A cirurgia. 2011. Disponível [online] em: <http://www.sbcb.org.br/cbariatrica.php?menu=0>. Acesso em: 10 Ago.12.

85. Sociedade Brasileira de Cirurgia Bariátrica e Metabólica. Tipos de cirurgia para a obesidade. 2010. Disponível [online] em: <http://www.sbcbm.org.br/paciente.php?cod=4>. Acesso em: 11 Set. 2013. 
86. Leite MAM; Rodrigues MPF. Procedimentos Cirúrgicos: introdução histórica. In: Garrido JAB, Ferraz EM, Barroso FL et al. Cirurgia da obesidade. Sociedade Brasileira de Cirurgia Bariátrica. São Paulo: Atheneu, 2002.

87. Silva RS. Indicações cirúrgicas no tratamento da obesidade. In: Silva RS, Kawahara NT. Cuidados pré e pós-operatório na cirurgia da obesidade. Porto Alegre: AGE, 2005.

88. Branco-Filho AJ, Nassif LS, Menacho AM, Aurichio RAE, Siqueira DED, Fernandez RM. Tratamento da obesidade mórbida com a gastrectomia vertical. ABCD Arq Bras Cir Dig Artigo Original 2011;24(1): 52-54. Disponível [online] em:< http://www.scielo.br/pdf/abcd/v24n1/v24n1a11.pdf >. Acesso em: 05 Jun. 2013.

89. Silva RS. Indicações cirúrgicas no tratamento da obesidade. In: Silva RS; Kawahara NT e colaboradores. Cuidados pré e pós-operatório na cirurgia da obesidade. Porto Alegre, RS: AGE, p. 60-64, 2005.

90. Mason EE, Doherty C, Cullen JJ, Scott D, Rodriguez EM, Maher JW. Vertical gastroplasty: evolution of vertical banded gastroplasty. World Journal of Surgery. 1998 Sep;22(9):919-24. Disponível [online] em:<

http://www.ncbi.nlm.nih.gov/pubmed/9717417>. Acesso em: 14 Mai. 2013.

91. DeMaria EJ. Laparoscopic adjustable silicone gastric banding. Surg Clin North Am. 2001;81(5):1129-44,vii. Disponível [online] em:<

http://www.unboundmedicine.com/medline/journal/Surg_Clin_North_Am?start= 1240\&next=true>. Acesso em: 08 Jun. 2013.

92. Capella JF, Capella RF. The weight reduction operation of choice: Vertical banded gastroplasty or gastric bypass? Am J Surg 1996;171:74-9. Disponível [online] em:<

http://www.ncbi.nlm.nih.gov/pubmed/8554155>. Acesso em: 10 Mai. 2013.

93. Doldi SB, Micheletto G, Di Prisco F, Zappa MA, Lattuada E; Reitano M. Intragastric balloon in obese patients. Obesity Sugery. 2000 Dec ;10(6):578-81. Disponível [online] em:<http://www.ncbi.nlm.nih.gov/pubmed/11175969>. Acesso em: 22 Jun. 2013.

94. Santoro S, Velhote MCP, Malzoni CE, Mechenas ASG, Strassmann V, Scheinberg M. Adaptação digestiva: Uma nova proposta cirúrgica para tratar a obesidade com base em fisiologia e evolução. Einstein 2003; 1:95-8. Disponível [online] em:<

http://www.einstein.br/biblioteca/artigos/adaptacao\%20digestiva\%20traduzido.p df>. Acesso em: 16 Abr. 2010.

95. Damaso C. Cirurgia bariátrica completa 25 anos no Brasil. Revista Nutritotal. Entrevista com Doutor Sérgio Santoro. 04/09/2009. Disponível [online] em:< 
http://www.nutritotal.com.br/notas_noticias/?acao=bu\&id=405>. Acesso em: 25 Jun. 2014.

96. Radford M, Deo.P. New No-Surgery Weight Loss Procedure Shows Promise. NBCNEWS. Publicado em: 05 Abr. 2016. Disponível [online] em:<http://www.nbcnews.com/health/health-news/new-no-surgery-weight-lossprocedure-shows-promise-n551276>. Acesso em: 10 Mai. 2016.

97. Sullivan $S$, Stein $R$, Jonnalagadda $S$, Mullady D, Edmundowicz $S$. Aspiration Therapy Leads to Weight Loss in Obese Subjects: A pilot Study. Gastroenterology 2013; 145: 1245-1252. Disponível [online] em: <http://www.gastrojournal.org/article/S0016-5085(13)01276-6/fulltext>. Acesso em: 16 Jun. 2016.

98. Brasil. Ministério da Saúde. Doenças ligadas à obesidade custam $\mathrm{R} \$ 488$ milhões. 19 de março de 2013. Disponível [online] em:<http://portalsaude.saude.gov.br/index.php/cidadao/principal/agenciasaude/noticias-anteriores-agencia-saude/3414->. Acesso em: 14 Fev. 2014.

99. Brasil. Ministério da Saúde. Portaria GM/MS n. .628 , de 26 de abril de 2001. Protocolo de Indicação de Tratamento Cirúrgico da Obesidade Mórbida Gastroplastia no âmbito do Sistema Único de Saúde - SUS. Brasília. Disponível em:<http://www.saude.mg.gov.br/images/documentos/portaria_0628.pdf>.

[online] Acesso em: 22 Jun. 2012.

100. Sociedade Brasileira de Cirurgia Bariátrica e Metabólica. Cirurgia para a obesidade. 2013.2 Disponível [online] em: <http://www.sbcbm.org.br/paciente.php?cod=4>. Acesso em: 11 Set. 2013.

101. Ramos A. O Brasil procurando preencher o seu espaço na cirurgia bariátrica. $A B C D$, arq. bras. cir. dig. vol.27 supl.1 São Paulo 2014. Disponível [online] em:<http://dx.doi.org/10.1590/S0102-6720201400S100001>. Acesso em: 23 Jan. 2015.

102. Brolin RE. Bariatric surgery and long-term control of morbid obesity. JAMA. v.288, p. 2793-2796, 2002. Disponível [online] em: <http://www.ncbi.nlm.nih.gov/pubmed/12472304>. Acesso em: 26 Jul. 2014.

103. Soares CC, Falcão NC. Abordagem nutricional nos diferentes tipos de cirurgia bariátrica. Revista Brasileira de Nutrição Clínica, Porto Alegre, v. 22, n. 1,p. 55-64, 2007. Disponível [online] em: $<$ http://nutricore.com.br/app/webroot/img/bibliotecas/Abordagem\%20nutricional \%20nos\%20diferentes\%20tipos\%20de.pdf>. Acesso em: 26 Jul. 2014.

104. Garrido Júnior AB, Halpern A, Rodrigues JJG. Cirurgia para obesidade grave: vivência de duas décadas. Rev Bras Nutr Clín 2000; 15(3):400-5. Disponível [online] em:<http://www.scielo.br/scielo.php?script=sci_nlinks\&ref=000096\&pid=S1415 -5273200400020001300001 \&lng=es>. Acesso em: 16 Ago 2013. 
105. Conselho Federal de Medicina. Conselho Federal de Medicina debate caminhos da cirurgia bariátrica e metabólica. Jornal de Medicina. Fev. 2011. Brasília. Disponível [online] em:< http://www.eventos.cfm.org.br/index.php?option=com_content\&view=article\&id= 21003\&ltemid=486>. Acesso em: 22 Mai. 2013.

106. Brasil. Ministério da Saúde. Portaria GM/MS no 196, de 29 de Fde 2000. Aprova, na forma do Anexo desta Portaria, os critérios clínicos para a indicação de realização de gastroplastia como tratamento cirúrgico da obesidade mórbida, no âmbito do Sistema Único de Saúde. Brasília, 2000. [online]. Disponível

em:< sna.saude.gov.br/legisla/legisla/alta.../GM_P196_00alta_gastro.doc>. Acesso em: 14 Fev. 2012.

107. Brasil. Ministério da Saúde. Saúde habilita mais dois hospitais para realizar cirurgia bariátrica. 26/05/2011. [online]. Disponível em:< http://portalsaude.saude.gov.br/index.php/cidadao/principal/agenciasaude/noticias-anteriores-agencia-saude/5362->. Acesso em: 14 Fev. 2012.

108. Brasil. Ministério da Saúde. Portaria GM/MS n.ำ 628, de 26 de abril de 2001. Aprova o Protocolo de Indicação de Tratamento Cirúrgico da Obesidade Mórbida - Gastroplastia no âmbito do Sistema Único de Saúde - SUS. [online]. Disponível em: <http://www.saude.mg.gov.br/images/documentos/portaria_0628.pdf>. Acesso em: 15 Abr. 2010.

109. Brasil. Ministério da Saúde. Portaria oㅡ 1.569 de 28 de Junho de 2007. Institui diretrizes para a atenção à saúde, com vistas à prevenção da obesidade e assistência ao portador de obesidade, a serem implantadas em todas as unidades federadas, respeitadas as competências das três esferas de gestão. [online]. Disponível

em: <http://www1.saude.rs.gov.br/dados/1190226841718GM-1569.html. Acesso em: 15 Abr. 2010.

110. Brasil. Ministério da Saúde. Portaria № 1.570 de 28 de junho de 2007. Determina que a Secretaria de Atenção à Saúde, isoladamente ou em conjunto com outras Secretarias do Ministério da Saúde, adote todas as providências necessárias à organização da assistência ao portador de obesidade grave. [online]. Disponível em: http://www1.saude.rs.gov.br/dados/1190226882504GM-1570.html>. Acesso em: 15 Abr. 2010.

111. Brasil. Ministério da Saúde. Secretaria de Atenção à Saúde. Portaria $n^{\circ}$ 492, de 31 de agosto de 2007. Definir Unidade de Assistência de Alta Complexidade ao Paciente Portador de Obesidade Grave como o hospital que ofereça assistência diagnóstica e terapêutica especializada, de média e alta complexidade, condições técnicas, instalações físicas, equipamentos e recursos humanos adequados ao atendimento às pessoas portadoras de obesidade grave. [online]. Disponível em: < http://bvsms.saude.gov.br/bvs/saudelegis/sas/2007/prt0492_31_08_2007_rep_ comp.html>. Acesso em: 15 Abr. 2010. 
112 Brasil. Ministério da Saúde. Portaria o 425, de 19 de março de 2013. Estabelece regulamento técnico, normas e critérios para o Serviço de Assistência de Alta Complexidade ao Indivíduo com Obesidade. Diário Oficial República Federativa do Brasil. Imprensa Nacional Brasília - DF. o 71 - DOU - 15/04/13 - seção 1 - p.59. [online]. Disponível em: < ftp://ftp.saude.sp.gov.br/ftpsessp/bibliote/informe_eletronico/2013/iels.abr.13/lel s70/U_PT-MS-GM-425-REP_190313.pdf>. Acesso em: 25 Abr. 2013.

113. Sociedade Brasileira de Cirurgia Bariátrica e Metabólica. Obesidade sem marcas. Cirurgia menos invasiva é um direito. 2010. [online]. Disponível em:< http://www.sbcbm.org.br/imagens/PressKit_SBCBM.pdf>. Acesso em: 26 Jan. 2012

114. Conselho Federal de Medicina. Resolução CFM No ${ }^{\circ} .766 / 05$. Publicada no D.O.U., 11 jul 2005, Seção I, p. 114. (Alterada pela Resolução CFM no 1942/2010). [online]. Disponível em:< http://www.portalmedico.org.br/resolucoes/cfm/2005/1766_2005.htm>. Acesso em: 26 Jan. 2012.

115. Keating C, Neovius M, Sjöholm K, Peltonen M, Narbro K, Eriksson JK, Sjöström L, Carlsson LMS. Health-care costs over 15 years after bariatric surgery for patients with different baseline glucose status: results from the Swedish Obese Subjects study. The Lancet Diabetes \& Endocrinology, Vol. 3 no $11, \quad$ Nov. 2015 pp. 855-865. Disponível em:<http://www.thelancet.com/pdfs/journals/landia/PIIS2213-8587(15)002909.pdf>._Acesso em: 12 Nov. 2015.

116. Vidale G. Cirurgia bariátrica deve priorizar diabéticos -- e não apenas obesos: Um novo estudo mostrou que o procedimento é efetivo para os pacientes com diabetes tipo 2 tanto sob ponto de vista clínico quanto econômico -- os portadores da doença que se submetem à cirurgia reduzem os gastos com medicamentos e atendimento médico em até 30\%. Revista Veja. Publicado em 21/09/2015. Disponível [online] em:<http://veja.abril.com.br/noticia/saude/cirurgia-bariatrica-deveria-priorizarpacientes-diabeticos/>. Acesso em: 12 Nov. 2015.

117. Conselho Federal de Medicina. Resolução CFM no 2.131/2015 (Publicada no D.O.U. em 13 jan. 2016, Seção I, p. 66). Altera o anexo da Resolução CFM no 1.942/10, publicada no D.O.U. de 12 de fevereiro de 2010, Seção I, p. 72. Disponível em:<http://www.portalmedico.org.br/resolucoes/CFM/2015/2131_2015.pdf>. Acesso em: 14 Jan. 2016.

118. Lemos SLS, Domingos TA, Vinha JM, Nadai AP, Vasconcellos CP, Ferragut CB. Nova proposta de tratamento cirúrgico da obesidade: gastrectomia vertical e bypass intestinal parcial: resultados preliminares. Rev Bras Videocir, 2005; 3 (3): 131-142. Disponível [online] em:<http://sobracil.org.br/revista/rv030303/rbvc030303_131.pdf>. Acesso em: 14 Abr. 2012. 
119. Instituto de Estudos de Saúde Suplementar - IESS. Cirurgia bariátrica pareceres técnico-científicos. Vol. 1. Núcleo de Avaliação de Tecnologias da Saúde - Departamento de Clínica Médica da Universidade do Estado do Rio de Janeiro - $\quad$ UERJ. $2008 . \quad$ Disponível [online] em:<http://iess.org.br/?p=publicacoes\&id_tipo=7>. Acesso em: 14 Abr. 2012.

120. Brolin RE. Bariatric surgery and long-term control of morbid obesity. JAMA. v. 288, p. 2793-2796, 2002. Disponível [online] em:<http://www.ncbi.nlm.nih.gov/pubmed/12472304>. Acesso em: 14 Out. 2012.

121. SBCBM - Sociedade Brasileira de Cirurgia Bariátrica e Metabólica Consenso Bariátrico. 2008. Disponível [online] em:<http://www.sbcb.org.br/membros_consenso_bariatrico.php>. Acesso em: 14 Out. 2012.

122. Farias F. Cirurgia bariátrica: história. In: Silva RS; Kawahara MT. Cuidados pré e pós-operatórios na cirurgia da obesidade. Porto Alegre: AGE, 2005.

123. Marcelino LF, Patrício ZM. A complexidade da obesidade e o processo de viver após a cirurgia bariátrica: uma questão de saúde coletiva. Ciênc. saúde coletiva vol.16 n.12 Rio de Janeiro Dec. 2011. Disponível [online] em: $<$ http://dx.doi.org/10.1590/S1413-81232011001300025>. Acesso em: 18 Abr. 2012.

124. Melo SMDA, Vasconcelos AR, Melo VA, Santos FA. Menezes Filho RS; Melo BSD. Cirurgia bariátrica: existe necessidade de internação em Unidade de Terapia Intensiva? Revista Brasileira de Terapia Intensiva, v. 21, n. 2, p. 162168, 2009. Disponível

em:<http://www.scielo.br/scielo.php?script=sci_arttext\&pid=S0103-

[online] 507X2009000200008>. Acesso em: 16 Dez. 2012.

125. Menezes MS; Harada KO; Alvarez G. Polineuropatia periférica dolorosa após cirurgia bariátrica. Relato de casos. Revista Brasileira de Anestesiologia. v. 58 , n. 3, p. 252-259, 2008. Disponível [online] em:< http://www.scielo.br/scielo.php?script=sci_arttext\&pid=S003470942008000300008>. Acesso em: 10 Dez. 2012.

126. Escalona A, Pérez G, León F, Volaric $C$, Mellado P, Ibáñez L, Guzmán S. Wernicke's Encephalopathy after Rouxen-Y Gastric Bypass. Obes Surg 2004; 14: 1135-7. Disponível [online] em:< http://www.ncbi.nlm.nih.gov/pubmed/15479607>. Acesso em: 11 Dez. 2012.

127. Diniz MTC, Diniz MFHS, Sanches SRA, Rocha ALS. Cirurgia Bariátrica e Metabólica - Abordagem Multidisciplinar. Rio de Janeiro: Atheneu Editora, 2013. 
128 Nóbrega G. Obesidade, Cirurgia Bariátrica e Emagrecimento - Vivências e Significados. Curitiba: Juruá editora, 2011.

129. Suzuki VY; Schneider AP. Atendimento Nutricional em Cirurgia Plástica Uma abordagem multidisciplinar. Rio de Janeiro: Rubio, 2013.

130. Villela NB, Braghrolli Neto O, Curvello KL, Paneili BE, Seal C, Santos D, Cruz T. Quality of life of obese patientes submitted to bariatric surgery. Nutrición Hospitalaria, 19 (6), 367-371, 2004. Disponível [online] em:< http://www.ncbi.nlm.nih.gov/pubmed/15672653>. Acesso em: 24 Jun. 2010.

131. Borda LA, Teixeira TFS, BreSSan J, Mourão DM. Cirurgia bariátrica: como e por que suplementar. Rev Assoc Med Bras 2011; 57(1):113-120. . Disponível [online] em:< http://www.scielo.br/pdf/ramb/v57n1/v57n1a25.pdf>. Acesso em: 24 Jun. 2010.

132. Flancbaum L, Belsley S, Drake V. Preoperative Nutritional Status of Pacients Undergoing Roux-en-Y Gastric Bypass for Morbid Obesity. Journal of Gastrointestinal Surgery 2006; 10:1033-1037. Disponível [online] em:< http://www.ncbi.nlm.nih.gov/pubmed/16843874>. Acesso em: 24 Jun. 2010.

133. IliasEJ. Conseqüências fisiológicas, psicológicas e metabólicas da cirurgia bariátrica. Rev. Assoc. Med. Bras. [online]. 2007, vol.53, n.2, pp. 98-98. Disponível [online] em:< http://www.scielo.br/pdf/ramb/v53n2/04.pdf>. Acesso em: 22 Jun. 2012.

134. Pedrosa IV, Burgos MGPA, Souza NC, Morais CM. Aspectos nutricionais em obesos antes e após a cirurgia bariátrica. Rev. Col. Bras. Cir. vol.36 no.4 Rio de Janeiro July/Aug. 2009. Disponível [online] em:<http://dx.doi.org/10.1590/S0100-69912009000400008>. Acesso em: 22 Ago. 2012.

135. Leal CW, Baldin N. Impacto emocional da cirurgia bariátrica em pacientes com obesidade mórbida. Ver. Psiquiatr. Rio Gd Sul. 2007, Vol. 29, № 3, pp. 324-327. Disponível [online] em: <http://www.scielo.br/pdf/rprs/v29n3/v29n3a13.pdf>. Acesso em: 17 Mar. 2012.

136. Gasgon B. Enfim magra, e agora? São Paulo: Jardim dos Livros (Geração Editorial), 2011.

137. Pinho PR, Chillof CLM, Mendes FH, Leite CVS, Fausto Viterbo F. Abordagem psicológica em cirurgia plástica pós-bariátrica. Rev. Bras. Cir. Plást. vol.26 no.4 São Paulo Oct./Nov./Dec. 2011. Disponível [online] em:< http://dx.doi.org/10.1590/S1983-51752011000400026 >. Acesso em: 06 Mai. 2013.

138. Silva-Neto EF, Vázquez CMP, Soares FM, Silva DG, Souza MFBC, Barbosa KBF. Cirurgia bariátrica reverte risco metabólico em pacientes assistidos em nível ambulatorial. ABCD Arq Bras Cir Dig Artigo Original 2014;27(1):38-42.

Disponível

[online] 
em:<http://www.scielo.br/pdf/abcd/v27n1/pt_0102-6720-abcd-27-01-00038.pdf >.Acesso em: 22 Nov. 2013.

139. Brasil. Ministério da Saúde. Portaria n. 0 545/GM Em 18 de março de 2002. Inclui na Tabela de Procedimentos do SIH-SUS o grupo de procedimentos Cirurgia Plástica Corretiva pós Gastroplastia e Dermolipectomia Abdominal, braquial, crural e mamoplastia pós Gastroplastia. Disponível [online] em: <http://www.sbccv.org.br/medica2old/downloads/Portaria\%20n.\%C2\%BA\%20545\%20-

GM\%20Em\%2018\%20de\%20mar\%C3\%A70\%20de\%202002.pdf>. Acesso em: 14 Nov. 2013.

140. Brasil. Ministério da Saúde. Portaria o 424, de 19 de março de 2013. Redefine as diretrizes para a organização da prevenção e do tratamento do sobrepeso e obesidade como linha de cuidado prioritária da Rede de Atenção à Saúde das Pessoas com Doenças Crônicas. Brasília. Disponível [online] em: <http://www.sbcb.org.br/legislacao.php?menu=4>. Acesso em: 22 Nov. 2013.

141. Tanaka DS, Peniche ACG. Assistência ao paciente obeso mórbido submetido à cirurgia bariátrica: dificuldades do enfermeiro. Acta paul. enferm. [online]. 2009, vol.22, n.5, pp. 618-623. Disponível [online] em: < http://www.scielo.br/pdf/ape/v22n5/04.pdf>. Acesso em: 22 Mai. 2012.

142. Gonçalves AF, Moraes DEB. Obesidade e sexualidade. Revista Brasileira de Sexualidade Humana. v. 15, n.1, p.103-112. 2004. Disponível [online] em: <http://www.sbrash.org.br/revistas/rbsh>. Acesso em: 10 Fev. 2011.

143. Mariano MLL, Paula MAB. Cirurgia bariátrica: repercussões na sexualidade do obeso mórbido. 2011. Universidade de Taubaté / Departamento de Enfermagem. XV Encontro Latino Americano de Iniciação Científica e XI Encontro Latino Americano de Pós-Graduação - Universidade do Vale do Paraíba. Disponível [online] em: <http://www.inicepg.univap.br/cd/INIC_2011/anais/arquivos/0046_0257_01.pdf> . Acesso em: 10 Fev. 2013.

144. Caprara A, Franco ALS. A Relação paciente-médico: para uma humanização da prática médica. Cad. Saúde Pública, Rio de Janeiro, 15(3):647-654, jul-set, $1999 . \quad$ Disponível [online] em:< http://www.scielo.br/pdf/csp/v15n3/0505.pdf>. Acesso em: 22 Jun. 2012.

145. Sarmento RA, Casagrande DS, Schaan BD. Cirurgia bariátrica no tratamento as obesidade: impacto sobre o metabolismo ósseo. Revista Hospitla Universitário Pedro Ernesto. Jan/Mar 2014 Vol. 13, oㅡ 1. Disponível [online] em:<http://revista.hupe.uerj.br/detalhe_artigo.asp?id=45>. Acesso em: 22 Jun. 2014.

146. Mancini MC; Geloneze B, Salles JEN, Lima JG, Carra M.K. Tratado de obesidade. Itapevi, SP: AC Farmacêutica, 2010.

147. Hambidge MK, Krebs NF; Miller L. Evaluation of zinc metabolism with use of stab le-isotope techniques: implications for the assessment of zinc status. 
American Society for Clinical Nutrition. Am. J. Clin. Nutr. 68 (sup pl): $410 \mathrm{~S}-$ 3S, $1998 . \quad$ Disponível [online] em:<http://ajcn.nutrition.org/content/68/2/410S.full.pdf>. Acesso em: $06 \mathrm{Fev}$. 2011.

148. Waitzberg D. Nutrição Oral, Enteral e Parenteral na prática clínica, $3^{\circ}$ ed. Rio de Janeiro: Atheneu, 2000.

149. Rhode BM, MacLean LD . Vitamin and Mineral Supplementation after gastric bypass. Chapter 19 p 161 - 169 Update: Surgery for the morbidly obese patient, 2000. Disponível [online] em:<http://www.pamtremble.com/wpcontent/uploads/2011/08/Vitamin_Mineral_Supplementation_after_WLS.pdf>.

Acesso em: 22 Abr. 2012.

150. lannelli A, Addeo P, Novellas S, Gugenheim J. Wernicke's encephalopathy after laparoscopic Roux-em-Y gastric by-pass: a misdiagnosed complication. Obes Surg. 2010 Nov; 20(11):1594-6. Disponível [online] em:<http://www.ncbi.nlm.nih.gov/pubmed/20195787>. Acesso em: 15 Jan. 2012.

151. Souto S, Ferro-Bucher JSN. Práticas indiscriminadas de dietas de emagrecimento e o desenvolvimento de transtornos alimentares. Rev Nutr. 2006;19(6):693-704. [online]. Disponível em:< http://www.scielo.br/scielo.php?script=sci_arttext\&pid=S141552732006000600006 >. Acesso em: Acesso em: 15 Jan. 2012.

152. Machado CE, Zilberstein B, Cecconello I, Monteiro M. Compulsão alimentar antes e após a cirurgia bariátrica. ABCD, arq. bras. cir. Dig. 2008, vol.21, n.4, pp. 185-191. Disponível [online] em:< http://www.scielo.br/pdf/abcd/v21n4/v21n4a07.pdf>. Acesso em: 22 Jun. 2012.

153. Farias PM, Furtado CAS, Morales G, Santos LC, Coutinho V. Compulsão alimentar em pacientes submetidos à cirurgia bariátrica. Rev Bras Nutr Clin 2009; $24 \quad$ (3): 137-42. Disponível [online] em:< http://www.sbnpe.com.br/_n1/docs/revistas/volume24-3.pdf>. Acesso em: 22 Jun. 2012.

154. Buddeberg-Fischer B, Klaghofer R, Krug L, Buddeberg C, Muller MK, Schoeb O. Physical and psychosocial outcome in morbidly obese patients with and without bariatric surgery: a 4 1/2-year follow-up. Obes Surg. 2006;16(3):321-30. Disponível [online] em:< Acesso em: 14 Jul.2012.

155. Adams TD, Gress RE, Smith SC, Halverson RC, Simper SC, Rosamond WD; LaMonte MJ; Stroup AM; Hunt S. Long-term mortality after gastric bypass surgery. N Engl J Med. 2007;357(8):753-61. [online]. Disponível em:< http://www.nejm.org/doi/full/10.1056/NEJMoa066603 >. Acesso em: 01 Mai. 2013.

156. Bhatti JÁ, Nathens AB, Thiruchelvam D, Grantcharov T, Goldstein BI, Redelmeier DA. Self-harm emergencies after bariatric surgery: a population- 
based cohort study. JAMA Surg. DOI: 10.1001/jamasurg.2015.3414. Epub 2015 Oct 7. Disponível [online] em:<http://www.ncbi.nlm.nih.gov/pubmed/26444444>. Acesso em: 15 Dez. 2015.

157. Potter VR. Bioethics, bridge to the future. Englewod Cliffs, New York: Prentice-Hall; 1971.

158. .Kottow M. 1995. Introducción a la bioética. Chile: Editorial Universitaria, 1995.

159. Singer P. Ética prática. Trad. Manuel Joaquim Vieira. Lisboa: Tipografia Lugo, 1993. [online]. Disponível em: <http://pt.scribd.com/doc/7299953/PeterSinger-Etica-Pratica>. Acesso em: 12 Jun. 2014.

160. Porto D, Garrafa V.A influência da Reforma Sanitária na construção das bioéticas brasileiras. Ciênc. saúde coletiva 2011, vol.16, suppl.1, pp. 719-729. [online]. Disponível em: <http://www.scielo.br/pdf/csc/v16s1/a02v16s1.pdf>. Acesso em: 14 Jul.2012.

161. BBC Brasil. Pais congelam filha morta por esperança de fazê-la renascer. BBC Brasil Portal Terra/Ciência. Publicado em 15/10/2015. Disponível [online] em:< http://noticias.terra.com.br/ciencia/pais-congelam-menina-de-2-anos-quemorreu-de-cancer-por-esperanca-de-faze-la-

renascer,6e946c8b7f973a27e9ef88a44d12cd987uxkh0jh.html>. Acesso em: 16 Out. 2015.

162. Beauchamp TL, Childress JF. Principles of Biomedical Ethics. $4^{\circ}$ ed. New York: Oxford, 1994:100-103.

163. Garrafa V. Bioética. In: Giovanella L, Escorel S, Lobato LVC, Noronha JC, Carvalho Al. Políticas e Sistema de Saúde no Brasil. Rio de Janeiro: Editora Fiocruz/Cebes, 2009, pp. 853-870.

164 Berlinguer G. Ética da saúde. São Paulo: Hucitec; 1996.

165. Schramm FR, Castiel LD. Bioética e saúde pública. [Internet]. Caderno de Saúde Pública, Rio de Janeiro: UFRJ/FIOCRUZ, 15 (Sup.1) pp. 4-5, 1999. Disponível [online] em: http://www.scielo.br/pdf/csp/v15s1/0331.pdf. Acesso em: 15 Mai. 2010.

166. Schramm FR, Rego S, Braz M, Palácios M. (Org). Bioética, Riscos e Proteção. Rio de Janeiro: UFRJ/FIOCRUZ, 2006.

167. Garrafa V. O novo conceito de Bioética. In: Garrafa V, Kottow M, Saada A. Bases conceituais da bioética - enfoque latino-americano. São Paulo: Gaia / Unesco, 2006, pp. 09-15.

168. Brasil. Ministério da Saúde. Secretaria de Atenção à Saúde. Departamento de Atenção Básica. Estratégias para o cuidado da pessoa com 
doença crônica: obesidade / Ministério da Saúde, Secretaria de Atenção à Saúde, Departamento de Atenção Básica. - Brasília : Ministério da Saúde, $2014 . \quad$ [online]. Disponível em: $<$ http://bvsms.saude.gov.br/bvs/publicacoes/estrategias_cuidado_doenca_croni ca_obesidade_cab38.pdf>. Acesso em: 07 Fev. 2015.

169. International Bioethics Committee . Report of the IBC on the Principle of Non-discrimination and Non-stigmatization. Paris, 6 March 2014. Disponível [online] em:<http://unesdoc.unesco.org/images/0022/002211/221196E.pdf>. Acesso em: 15 Abr. 2014.

170. Rezende JM. História da medicina. Juramento de hipócrates. Revista Paraense de Medicina, vol. 17(1):38-47, abril-junho de 2003. [online]. Disponível em:< http://books.scielo.org/id/8kf92/pdf/rezende-978856167363504.pdf>. Acesso em: 03. Nov. 2012.

171. Martins J S. Educação Médica e profissionalismo. Acta Med Port 2013 JulAgo; 26 (4): 420-427. [online]. Disponível em:< www.actamedicaportuguesa.com/revista/index.php/amp/article/.../3716>. Acesso em: 10 Mar. 2014.

172. Vieira S, Hossne WS. Pesquisa Médica: A Ética e a Metodologia (1998). São Paulo: Pioneira.

173. Drumond JGF. O princípio da beneficência na responsabilidade civil do médico. Bioética e direito médico. Conferência proferida no I Simpósio Iberoamericano de Direito Médico, Montevidéu (Uruguai) Setembro de 2000. [online]. Disponível em: < http://www.ibemol.com.br/sodime/artigos/BIOETICA_DIREITO_MEDICO.htm>. Acesso em: 25 Abr. 2013.

174. Matos GEC. Aspectos jurídicos e bioéticos do consentimento informado na prática médica. Revista Bioética 200715 (2): 196-213. [online]. Disponível em: $<$

http://revistabioetica.cfm.org.br/index.php/revista_bioetica/article/viewArticle/41 >. Acesso em: 14 Dez. 2013.

175. Koerich MS, Machado RR, Costa E. Ética e bioética: para dar início à reflexão. Texto Contexto Enferm 2005 Jan-Mar; 14(1):106-10. [online]. Disponível em: <http://www.scielo.br/pdf/tce/v14n1/a14v14n1>. Acesso em: 02 Mar. 2013.

176. The Belmont Report: Ethical Guidelines for the Protection of Human Subjects. Washington: DHEW Publications (OS) 78-0012, 1978.

177. Drumond JGF. Bioética clínica e direito médico. Revista BioethikosCentro Universitário São Camilo - 2012;6(1):78-89. [online]. Disponível em: $<$ http://www.saocamilo-sp.br/pdf/bioethikos/91/a08.pdf>. Acesso em: 02 Mar. 2013. 
178. Garrafa G, Soares SP. O princípio da solidariedade e cooperação na perspectiva bioética. Revista Bioethikos- Centro Universitário São Camilo 2013;7(3):247-258.

179. Almeida JLT, Schramm FR. Paradigmatic transition, medical ethics metamorphosis and the rise of bioethics. Cad Saúde Pública. 1999;15(supl 1):15-25. [online]. Disponível em: <http://www.scielosp.org/pdf/csp/v15s1/0333.pdf>. Acesso em: 10 Fev. 2012.

180. Wanssa MCD. Autonomia versus beneficência. Revista Bioética (Impr.) 2011; 19(1): 105 - $17 . \quad$ [online]. Disponível em: <http://revistabioetica.cfm.org.br/index.php/revista_bioetica/article/viewFile/611/ 627>. Acesso em: 18 Jun. 2012.

181. Batista e Silva H. Beneficência e paternalismo médico. Rev. Bras. Saúde Matern. In fant., Recife, 10 (Supl. 2): S419-S425 dez., 2010. Disponível [online] em: $\quad<\quad$ http://www.scielo.br/scielo. php?pid=S151938292010000600021\&script=sci_arttext>. Acesso em: 02 Mar. 2013.

182. Pellegrino E, Thomasma D. For the patient's good: the restoration of beneficence in health care. Journal of the Royal College of General Practitioners. November. New York: Oxford University Press, 1988:526. [online]. Disponível em: <http://www.ncbi.nlm.nih.gov/pmc/articles/PMC1711632/pdf/jroyalcgprac000230041a.pdf>. Acesso em: 14 Jun. 2013.

183. Ross WD. The right and the Good. Oxford: Clarendon, 1930:21-22.

184. Durant G. Introdução geral à bioética. São Paulo: Loyola; 2003.

185. Bentham J. An introduction to the principles of moral and legislation. Oxford: Clarendon Press; 1970. p.11-4; 31-4. [online]. Disponível em: < http://socserv.mcmaster.ca/econ/ugcm/3ll3/bentham/morals.pdf>. Acesso em: 02 Mar. 2013.

186. Silva HB. Beneficência e paternalismo médico. Rev. Bras. Saude Mater. Infant. 2010, vol.10, suppl. .2, pp. s419-s425. [online]. Disponível em: < http://www.scielo.br/scielo.php?pid=S1519-

38292010000600021\&script=sci_arttext>. Acesso em: 02 Mar. 2013.

187. Dicionário Priberam da Língua Portuguesa Dano, 2008-2013. [online] Disponível em: < http://www.priberam.pt/dlpo/dano>. Acesso em: 23 Nov. 2013.

188. Gillon R. Primum non nocere and the principle of non-maleficence. British Medical Journal BMJ Publishing Group. 1985; 291:130-1. Disponível [online] em: <http://www.ncbi.nlm.nih.gov/pmc/articles/PMC1416256/pdf/bmjcred004560042.pdf. Acesso em: 26 Mai. 2013.

189. Garrafa V, Porto D. "Intervention bioethics: a proposal for peripheral countries in a context of power and injustice", Bioethics, 17 (5-6), 2003 : 399- 
416. [online]. Disponível em: < http://www.ncbi.nlm.nih.gov/pubmed/14870763>. Acesso em: 02 Mar. 2013.

190. Houaiss A, Villar MS. Dicionário Houaiss da língua portuguesa. Rio de Janeiro: Objetiva; 2001.

191. Hossne WS. Dos referenciais da Bioética - a Prudência. Revista Bioethikos - Centro Universitário São Camilo - 2008; 2(2):185-196. [online]. Disponível em: <http://www.saocamilo-sp.br/pdf/bioethikos/64/185a196.pdf. Acesso em: 22 Ago. 2013.

192. Saad ERD, Lima AP, Rodrigues C, Amorim F, Yasuda F, Santos GA, Bem PNI, Lozano VF. Bioética aplicada a pesquisa e inovação farmacêutica. Rev. Pesq. Inov. Farm., 1(1): 53-62, ago-dez, 2009. [online]. Disponível em: < http://periodicos.homologa.uniban.br/index.php/RPINF/article/viewFile/69/pdf5>. Acesso em: 04 Jul. 2014.

193. Brasil. Constituição da República Federativa do Brasil de 1988. Presidência da República Casa Civil Subchefia para Assuntos Jurídicos. Brasília, 5 de outubro de 1988. Disponível [online] em: < http://www.planalto.gov.br/ccivil_03/constituicao/constituicao.htm>. Acesso em: 14 Abr. 2010.

194. Sarlet IW. Dignidade da Pessoa Humana e Direitos Fundamentais na Constituição Federal de 1988. Porto Alegre: Livraria do Advogado Editora, 2011.

195. Kant I. Fundamentação da metafísica dos costumes e outros escritos. Trad. de Leopoldo Holzbach. São Paulo: Martin Claret, 2005.

196. Campos ECH, Sarlet IW. O princípio da dignidade da pessoa humana como argumento para a tutela do direito fundamental à saúde pelo Poder Judiciário Brasileiro. Faculdade de Ciências Jurídicas e Sociais - Direito, PUCRS, Bolsa PROBIC/FAPERGS. XII Salão de Iniciação Científica - PUCRS, 03 a 07 de outubro de 2011. Disponível [online] em:<http://ebooks.pucrs.br/edipucrs/anais/SIC/XII/XII/7/6/3/2/7.pdf>. Acesso em: 05 Jun. 2012.

197. STJNoticias. Cirurgia bariátrica, uma conquista médica e judicial. 27 Mar. 2011. [online]. Disponível em: $<$ http://www.stj.gov.br/portal_stj/publicacao/engine.wsp?tmp.area=398\&tmp.text o=101222 $>$. Acesso em: 02 Mar. 2012.

198. Brasil. Lei 8.080, de 19 de setembro de 1990. Dispõe sobre as condições para a promoção, proteção e recuperação da saúde, a organização e 0 funcionamento dos serviços correspondentes e dá outras providências. Presidência da República. Casa $\quad$ Civil Subchefia para Assuntos Jurídicos. Brasília, 1990. Disponível [online] em:< http://www.planalto.gov.br/ccivil_03/Leis/L8080.htm>. Acesso em: 19 Abr. 2010. 
199. Organização Mundial da Saúde. Obesidade: prevenindo e controlando a epidemia global. São Paulo: Roca, 2004.

200. Dicionário Global. Dicionário Português. Estigma. [online]. Disponível em: <http://www.dicionarioglobal.com/portugues/77492-estigma>. Acesso em: 15 Jul. 2013.

201. D'adesky J, Borges E, Medeiros CA. Racismo, Preconceito e intolerância. $7^{\circ}$ ed. Atual Editora, 2013.

202. Luiz G. Estereótipos e estigmatização. 2011. [online]. [Acesso em 2013 Jan. 12]. Disponível em: <http://www. grupoescolar.com/pesquisa/estereotipose-estigmatizacao.html.>. Acesso em: Acesso em: 14 Jun. 2013.

203. Lyra B, Santana G. (Orgs). Corpo \& Mídia. São Paulo: Arte \& Ciência, 2003.

204. Goffman E. Estigma: notas sobre a manipulação da identidade deteriorada. 4. ed. Rio de Janeiro: Guanabara, 1998.

205. Human Rights in Saudi Arabia: A Deafening Silence. Human Rights Watch Backgrounder, December 2001. [online]. Disponível em: < http://www.hrw.org/legacy/backgrounder/mena/saudi/saudi.pdf>. Acesso em: Acesso em: 14 Jun. 2010.

206. Teixeira Filho FS. Do estigma à exclusão - histórias de corpos (Des) acreditados. São Paulo: Casa do Psicólogo, 2012.

207. Monteiro S, Villela W. Estigma e saúde. Rio de Janeiro: Fiocruz, 2013.

208. Andrade MAR. Estigma e Velhice: ensaios sobre a manipulação da idade deteriorada. Revista Kairós Gerontologia, 14(1). São Paulo, março 2011. [online]. Disponível em: <http://revistas.pucsp.br/index.php/kairos/article/viewFile/6928/5020>. Acesso em: 13 Nov. 2013.

209. Onusida. Estigma, discriminação e violação dos direitos humanos em relação ao $\mathrm{VIH}$. Estudos de casos de programas bem sucedidos. (colecção Melhores Práticas da ONUSIDA). Programa Conjunto das Nações Unidas sobre o VIH/SIDA Dados do Catálogo de Publicações da Biblioteca da OMS. Genebra - Suiça, Abril de 2005. ONUSIDA/05.05P (versão portuguesa, Setembro de 2005). Disponível [online] em:

<http://whqlibdoc.who.int/unaids/portuguese/929173344X_por.pdf>. Acesso em: 28 Mai. 2012.

210. Garrafa V, Godoi AMM, Soares SP. HIV/AIDS and the principle of nondiscrimination and non-stigmatization. Revista Latinoamericana de Bioética 2012 Vol. 12 no 2 pp. 118-123. Universidad Militar Nueva Granada, Bogotá Colômbia. 
211. Mattos R. Sobrevivendo ao estigma da gordura. São Paulo: Vetor, 2012.

212. Latner JD, Stunkard AJ. Piorando: A estigmatização das crianças obesas. Obes Res. 2003.

213. Boscatto EC, Duarte MFS, Gomes MA, Gomes GMB. Aspectos físicos, psicossociais e comportamentais de obesos mórbidos submetidos à cirurgia bariátrica. J Health Sci Inst. 2010;28(2):195-8. [online]. Disponível em:< http://www.unip.br/comunicacao/publicacoes/ics/edicoes/2010/02_abrjun/V28_n2_2010_p195-198.pdf>. Acesso em: 10 Jan. 2012.

214. Brown H. For Obese People, Prejudice in Plain Sight. Published: March 16, 2010, on page D6 of the New York edition. [online]. Disponível em: <http://www.nytimes.com/2010/03/16/health/16essa.html?_r=1>. Acesso em: 12 Jun. 2012.

215. Ricoeur P. Etapa atual do pensamento sobre a tolerância. In: Academia Universal das Culturas (Org.). A intolerância.Rio de Janeiro: Bertrand Brasil, 2000.

216. Dutra VS, Selau B. Refletindo sobre a discriminação e preconceito com o corpo no espaço escolar. EFDeportes.com, Revista Digital. Buenos Aires, Ano 15, no 152, Janeiro 2011. Disponível [online] em:<http://www.efdeportes.com/>. Acesso em: 05 Mai. 2012.

217. Bourdieu P. A Escola conservadora: as desigualdades frente à escola e à cultura. In: Nogueira MA; Catani A. (orgs). Escritos de educação. Petrópolis, Vozes, 1998.

218. Garrafa V. Multi-inter-transdisciplinaridade, complexidade e totalidade concreta em bioética. In: Garrafa V, Kottow M \& Saada A (Orgs.) Bases Conceituais da Bioética: enfoque latino-americano. São Paulo: Gaia/Unesco, 2006. 73-86.

219. Teixeira Filho FS. Do estigma à exclusão - histórias de corpos (Des) acreditados. São Paulo: Casa do Psicólogo, 2012.

220. Rodrigues L. Pedro Toledo: A discriminação contra os obesos. VioMundo.publicado em 06 de fevereiro de 2011. [online]. Disponível em: <http://www.viomundo.com.br/voce-escreve/pedro-toledo-a-discriminacaocontra-os-obesos.html>. Acesso em: 28 Mai. 2012.

221. Simões AG, Paganelli CJM. A obesidade como impedimento à investidura em cargo público tendo a (des) igualdade fundada na lógica do (ir) razoável. In: Âmbito Jurídico, Rio Grande, XVI, n. 118, nov 2013. [online]. Disponível em: $<$ http://ambito-

juridico.com.br/site/?n_link=revista_artigos_leitura\&artigo_id=13407\&revista_ca derno=9>. Acesso em: 15 Out $201 \overline{4}$.

222. Guglinski V. Ficha Lipo: candidatos obesos, concursos públicos e o peso da

(in)justiça. [online].

Disponível

em: 
<http://vitorgug.jusbrasil.com.br/artigos/111867358/ficha-lipo-candidatosobesos-concursos-publicos-e-o-peso-da-in-justica>. Acesso em: 15 Out 2014.

223. The Gardian. Obesity can be a disability, EU court rules. Publicado em Dez. 2014. Obesity. [online] Disponível em:< http://www.theguardian.com/society/2014/dec/18/obesity-can-be-disability-eucourt-rules>. Acesso em: 22 Dez. 2014.

224. Agência Italiana de Notícias. Garoto violentado por ser gordo se reunirá com Papa - Jovem foi atacado com tubo de compressor de ar em Nápoles. 25 Out. 2014. Notícias do Vaticano. [online] Disponível em:< http://ansabrasil.com.br/brasil/noticias/vaticano/noticias/2014/10/24/Garotoviolentado-ser-gordo-se-reunira-com-Papa_8140245.html>. Acesso em: 19 Nov. 2014.

225. Leão LGR. O fenômeno bullying no ambiente escolar. Revista FACEVV Vila Velha | Número 4 | Jan./Jun. 2010 | p. 119-135. [online]. Disponível em:<http://www.facevv.edu.br/Revista/04/O\%20FEN\%C3\%94MENO\%20BULL YING\%20NO\%20AMBIENTE\%20ESCOLAR\%20-\%20leticia\%20gabriela.pdf>. Acesso em: 16 Set. 2016.

226. Neto AA, Saavedra LH. Diga NÃO para o Bullying. Rio de Janeiro: ABRAPI; 2004.

227. Smith PK, Talamelli L, Cowie H, Naylor P, Chauhan P. Profiles of nonvictims, escaped victims, continuing victims and new victims of school bullying. $\mathrm{Br} J$ Educ Psychol. 2004 Dec;74:565-581. [online]. Disponível em: $<$ www.ingentaconnect.com/content/bpsoc/bjep/2004/00000074/ 00000004/art00005>. Acesso em: 10 Mai. 2011.

228. Lopes Neto AA. Bullying . comportamento agressivo entre estudantes. Jornal de Pediatria - Vol. 81, oㅜ (Supl), 2005. [online]. Disponível em: $<$ http://www.scielo.br/pdf/jped/v81n5s0/v81n5Sa06.pdf>. Acesso em: 13 Jan. 2012.

229. Mayes C. The Harm of Bioethics: A Critique of Singer and Callahan on Obesity. Bioethics. 2015 Mar;29(3):217-21. doi: 10.1111/bioe.12089. Epub 2014 Mar 24. Disponível [online] em: <http://www.readcube.com/articles/10.1111\%2Fbioe.12089?r3_referer=wol\&tra cking_action=preview_click\&show_checkout=1\&purchase_referrer=onlinelibrary .wiley.com\&purchase_site_license=LICENSE_DENIED>. Acesso em: 12 Mai. 2014.

230. Singer P. Libertação animal. Filosofia. Edição Revista. Santa Catarina: Lugano Editora, 2004.

231. Singer P, Mason J. The Ethics of What We Eat: Why Our Food Choices Matter. Rodale Books: New York, 2007.

232. Dávila S. Peter Singer - Dieta moral. Entrevista em EUA/Washington. O professor de bioética em Princeton Peter Singer fala sobre seu livro "Como Nos Alimentamos", discute a opção pelo vegetarianismo e defende a condenação 
religiosa da gula. Jornal Folha de São Paulo. Publicado em 03 Dez. 2006. Disponível [online] em: < http://www1.folha.uol.com.br/fsp/mais/fs0312200607.htm>. Acesso em: 22 Jan. 2012.

233. Singer $P$. Vida ética: os melhores ensaios do mais polêmico filósofo da atualidade. Trad. Alice Xavier. Rio de Janeiro: Ediouro, 2002.

234. Singer P. A ética do dia-a-dia. Entrevista a Gabriela Carelli. Veja, São Paulo, 21 fev. 2007. Disponível [online] em:< http://veja.abril.com.br/210207/entrevista.shtml> Acesso: 22 Jun. 2012.

235. Popkin BM. O Mundo Está Gordo - Modismos, Tendências, Produtos e Políticas que estão engordando a humanidade. Tradução de Ana Beatriz Rodrigues. Rio de Janeiro: Elsevier, 2011.

236. Singer P. Weigh More, Pay More. In: Project Syndicate: A world of ideas. 12 Mar.2012. Project Syndicate. Disponível [online] em: < http://www.projectsyndicate.org/commentary/weigh-more--pay-more>. Acesso em: 14 Fev. 2013.

237. Callahan, D. Obesity: Chasing an Elusive Epidemic. It's time to approach our public health crisis with an edgier strategy. Hastings Center Report Vol. 43 (1):34-40 January-February, 2013. Disponível [online] em: < http://onlinelibrary.wiley.com/doi/10.1002/hast.114/pdf >. Acesso em: 14 Set. 2013.

238. Barbezat D. True to vision: a response to Daniel Callahan's "Obesity: Chasing na Elusive Epidemic". The Center for Contemplative Mind in Society. 2013. Disponível [online] em: <http://www.contemplativemind.org/archives/1622>. Acesso em: 22 Fev. 2015.

239. Mayes C, Thompson DB. Is Nutritional Advocacy Morally Indigestible? A Critical Analysis of the Scientific and Ethical Implications of 'Healthy' Food Choice Discourse in Liberal Societies. Public Health Ethics 7 (2):158-169 (2014). Disponível [online] em: <http://phe.oxfordjournals.org/content/early/2014/06/19/phe.phu013.short?rss=1 >. Acesso em: 12 Out. 2014.

240. Singer $P$. The Ethics of What We Eat. Video [on line] Publisher Williams College. Disponível [online] em:<http://www.learnoutloud.com/Free-AudioVideo/Self-Development/Diet-and-Nutrition/Peter-Singer-The-Ethics-of-WhatWe-Eat/44409>. Acesso em: 12 Jun. 2014.

241. Smith WJ. Obesity an Excuse for Lifestyle Authoritarianism. National Review. 2012. Disponível [online] em:<http://www.nationalreview.com/humanexceptionalism/322658/obesity-excuse-lifestyle-authoritarianism-wesley-jsmith>. Acesso em: 14 Dez. 2014.

242. Nestle M, Pollan M. Food politics: How the food industy influences nutricion and helth. 2014 Versão digital. Disponível [online] em: $<$ https://www.bookbrowse.com/bb_briefs/detail/index.cfm/ezine_preview_numb 
er/2410/food-politics. Versão em PDF: http://www.leituraspdf.com.br/livros/foodpolitics>. Acesso em: 15 Abr. 2015.

243. Ross M. America's Obesity Epidemic Is Not a Moral Failing. The Huffington Post. EUA. 17 Jan 2015. Disponível [online] em:<http://www.huffingtonpost.com/food-riot/americas-obesityepidemic_b_4616504.html>. Acesso em: 22 Jun. 2015.

244. Documentary Films. The Weight of the Nation. Institute of Medicine. 2012. Disponível [online] em:<https://www.youtube.com/watch?v=-pEkCbqN4uo>. Acesso em: 15 Mai. 2014.

245. Hadas E. Obesity and the unhealthy economy. EUA: Reuters, 13 Mar. 2003. Thomson Reuters largest internacional multimedia news agency. Disponível [online] em: <http://blogs.reuters.com/edwardhadas/2013/03/13/obesity-and-the-unhealthy-economy/>. Acesso em: 14 Jan. 2014.

246. Pontes TE, Costa TF, Marum ABRF, Brasil ALD, Taddei JAAC. Orientação nutricional de crianças e adolescentes e os novos padrões de consumo: propagandas, embalagens e rótulos. Rev. paul. pediatr.[online]. 2009, vol.27, n.1, pp. 99-105. ISSN 1984-0462. Disponível em: <http://www.scielo.br/pdf/rpp/v27n1/15.pdf>. Acesso em: 14 Abr. 2012.

247. Felipe ST. O poder galactífero ao redor do mundo. Palestra apresentada no Curso de Extensão Implicações éticas, ambientais e nutricionais do consumo de leite bovino - uma abordagem crítica. Florianópolis: UFSC, Auditório do Centro de Ciências da Educação, 21 junho 2013, das 18:45 às 21:30. Disponível em: <http://www.pensataanimal.net/pensadores/152-sonia-tfelipe/383-implicacoes-eticas-ambientais-e-nutricionais-do-consumo-de-leitebovino-uma-abordagem-critica-sinopse >. Acesso em: 14 Abr. 2014.

248. Scott A L, Koon T, Gasevic D, Zhang X, Poirier PP, Rangaraian S, Seron $\mathrm{P}$, Kelishadi R, Tamil AM, Kruger A, Igbal R, Swidan H, Gómez-Arbeláez D, Yusuf R, Chifamba J, Kutty R, Karsidag K, Kumar R, Li W, Szuba A, Avezum A, Diaz R, Anand SS, Rosengren A, Yusuf S. The association between ownership of common household devices and obesity and diabetes in high, middle and low income countries. CMAJ. 2014 Mar 4; 186(4): 258-266. Disponível em:<http://www.ncbi.nlm.nih.gov/pmc/articles/PMC3940572/>. Acesso em: 06 Mai. 2015.

249. Cohen R. Leite: alimento ou veneno? São Paulo: Ground, 2005.

250. Keon J. Whitewash: The Disturbing Truth About Cow's Milk and Your Health. Canada: New Society Publishers, 2010.

251. Linn S. Consuming Kids: Protecting Our Children from the Onslaught of Marketing \& Advertising. Austrália: Anchor; Reprint Edition, 2005.

252. Linn S. Crianças do Consumo - a infância roubada. São Paulo: Instituto Alana, 2006. 
253. Robbins J. The Food Revolution: How Your Diet Can Help Save Your Life and Our World. Conari Press, 2001.

254. Schmid R. The Untold Story of Milk: the History, Politics and Science of Nature's Perfect Food: Raw Milk From Pasture-Fed Cows. Washington, DC: NewTrends Publishing, 2009.

255. Throsby K. The War on Obesity as a Moral Project: Weight Loss Drugs, Obesity Surgery and Negotiating Failure. Science as Culture. Volume 18, Issue 2 , 2009. Special Issue: Living Drugs. Disponível em: <DOI: 10.1080/09505430902885581 >. Acesso em: 10 Abr. 2012.

256. Klugman C. How youngis too young: bariatric surgery in toddlers. The American Journal of Biothics, $20015 . \quad$ Disponível em::<http://www.bioethics.net/2013/09/how-young-is-too-young-bariatricsurgery-in-toddlers/>. Acesso em: 22 Set. 2015.

257. Provenzano F. Obeso mórbido de 2 anos é o paciente mais jovem do mundo a fazer uma cirurgia bariátrica. Jornal O GLOBO. 20/09/2013. Disponível em:.< http://extra.globo.com/noticias/saude-e-ciencia/obesomorbido-de-2-anos-o-paciente-mais-jovem-do-mundo-fazer-uma-cirurgiabariatrica-10068571.html>. Acesso em: 24 Out. 2013.

258. Pinker S. The moral imperative for bioethics. article. The Boston Globe media partners. August de 2015. Disponível em:< https://www.bostonglobe.com/opinion/2015/07/31/the-moral-imperative-forbioethics/jmekoyzltau9oqv76jrk9n/story.html>. Acesso em: 29 Set. 2015.

259. Klugman C. Is bioethics too powerful? The American Journal of Bioethics, 17/09/2015. Disponível em:<http://www.bioethics.net/2015/09/is-bioethics-toopowerful-lessons-from-research/>. Acesso em: 29 Set. 2015.

260. Solomon MZ. Bioethicists do embrace science, but not indiscriminately. The Boston Globe media partners. August, 2015. Disponível em:< https://www.bostonglobe.com/opinion/letters/2015/08/05/bioethicists-embracescience-but-not-indiscriminately/bUpEU1SXIZ0Xu6uluVmgQP/story.html>. Acesso em 12 Set. 2015.

261. Perryman ML, Sidoti KA. Ethical considerations in the treatment of childhood obesity. March 2015 Volume 2015:5 Pages 17-26. Disponível em:< http://dx.doi.org/10.2147/MB.S63710>. Acesso em: 25 Ago. 2015.

262. Stefan M, GeelenV, Ineke LE, Bolt IL, Van der Baan-Slootweg OH, Marieke JH, van Summeren MJ. The Controversy Over Pediatric Bariatric Surgery An Explorative Study on Attitudes and Normative Beliefs of Specialists, Parents, and Adolescents With Obesity. Journal of Bioethical Inquiry. June 2013, Volume 10, Issue 2, pp 227-237. Disponível em:< http://link.springer.com/article/10.1007\%2Fs11673-013-9440-0>. Acesso em: 22 Set. 2014. 
263. Garrafa V. Da bioética de princípios a uma bioética interventiva. Revista Bioética, 2005 - Vol. 13, no 1 p. 125-134.

264. STJ - Superior Tribunal de Justiça. Cirurgia bariátrica, uma conquista médica e judicial. 2011. [online] JusBrasil. Disponível em:< http://stj.jusbrasil.com.br/noticias/2622137/cirurgia-bariatrica-uma-conquistamedica-e-judicial>. Acesso em: 14 Ago. 2012.

265. STJNoticias. Cirurgia bariátrica, uma conquista médica e judicial. 27 Mar. 2011. [online]. Disponível em: $<$ http://www.stj.gov.br/portal_stj/publicacao/engine.wsp?tmp.area=398\&tmp.text o=101222 >. Acesso em: 15 Jan. 2015.

266. Brasil. Lei no 9.656, de 3 de Junho de 1998. Dispõe sobre os planos e seguros privados de assistência à saúde. Presidência da República. Casa Civil. Subchefia para Assuntos Jurídicos. Brasília. Disponível em: < http://www.planalto.gov.br/ccivil_03/Leis/L9656.htm>. Acesso em: 22 Jun 2010.

267. ANS - Agência Suplementar de Saúde. Resolução Normativa - RN № 338, de 21 de Outubro de 2013. Atualiza o Rol de Procedimentos e Eventos em Saúde, que constitui a referência básica para cobertura assistencial mínima nos planos privados de assistência à saúde, contratados a partir de $1^{\circ}$ de janeiro de 1999; fixa as diretrizes de atenção à saúde; revoga as Resoluções Normativas - RN no 211, de 11 de janeiro de 2010, RN oㅡ 262, de 1 de agosto de 2011, RN o 281, de 19 de dezembro de 2011 e a RN oㅜ 325, de 18 de abril de 2013; e dá outras providências. Disponível em:< http://www.ans.gov.br/component/legislacao/?view=legislacao\&task=TextoLei\&f ormat=raw\&id=2591 >. Acesso em: 14 Abr. 2015.

268. Arendt H. A condição humana. 10. ed. Rio de Janeiro: Forense Universitária, 2001.

269. Assis OQ, Pozzoli L. Pessoa portadora de deficiência: direitos e garantias. 2 ed. São Paulo: Damásio de Jesus, 2005.

270. Werneck C. Manual sobre desenvolvimento inclusivo. Rio de Janeiro: WVA, 2005.

271. Minayo MCS. O desafio do conhecimento: pesquisa qualitativa em saúde. $11^{\circ}$ ed. São Paulo: Hucitec, 2008.

272. Schiffman L, Kanuk L. Comportamento do consumidor. LTC Editora. $6^{a}$ ed. 2000.

273. Gil AC. Métodos e técnicas de pesquisa social. 5. ed. São Paulo: Atlas, 1999.

274. Conselho Nacional de Saúde - CNS. Resolução 466 do CNS que trata de pesquisas em seres humanos. [online]. Disponível em: 
$<$ http://conselho.saude.gov.br/ultimas_noticias/2013/06_jun_14_publicada_reso lucao.html>. Acesso em: 14 Mai. 2013

275. Marconi MA, Lakatos EM. Fundamentos de metodologia científica. Porto Alegre: Atlas, 2005.

276. Pêcheux M. Discurso, estrutura ou acontecimento. Campinas: Pontes, 1997.

277. Orlandi Eni. Discurso em Análise: sujeito, sentido, ideologia. Campinas: Pontes, 2012.

278. Foucault M. A arqueologia do saber. Rio de Janeiro: Forense Universitária, 2004

279. Zárate A, Acevedo LB; Garcia RS. La Obesidad: conceptos actuales sobre fisiopatogenia y tratamiento. Rev. Faculdade de Medicina UNAM, México, v.44, n.2, p.66-70, marzo/abril. 2001. Disponível em:< http://www.ejournal.unam.mx/rfm/no44-2/RFM44206.pdf>. Acesso em: 12 Jul. 2014.

280. Feinstein M. Faith and Fat: Religious Youths More Likely to Be Obese by Mid-Life. March 24, 2011. By Courtney Hutchison, Abc News Medical Unit Via World News. Disponível em:< http://abcnews.go.com/Health/Diet/faith-fatreligious-youths-obese-mid-life/story?id=13204624>. Acesso em: 13 Abr. 2014.

281. The Organization for Economic Co-operation and Development. What are the social benefits of education? Education Indicators in Focus, January, 2013. Disponível em:<http://www.oecd.org/edu/skills-beyond-school/EDIF\%202013-N\%C2\%B010\%20(eng)--v9\%20FINAL\%20bis.pdf>. Acesso em: 23 Mar. 2015

282. Coob LK, McAdams-DeMarco MA, Gudzune KA, Anderson CAM, Demerath E, Woodward M, Selvin E, Coresh J. Changes in Body Mass Index and Obesity Risk in Married Couples Over 25 Years. The ARIC Cohort Study. American Journal of Epidemiology. Publicado em 03/01/2016. Disponível em: <http://aje.oxfordjournals.org/content/early/2015/09/23/aje.kwv112.abstract>. Acesso em: 15 Mar. 2016.

283. Hruschka DJ, Brewis AA, Wuitch A, Morin B. Shared Norms and Their Explanation for the Social Clustering of Obesity. American Journal of Public Health . 2011 December; 101(Suppl 1): S295-S300. doi: 10.2105/AJPH.2010.300053. Disponível em:<http://www.ncbi.nlm.nih.gov/pmc/articles/PMC3222514/>. Acesso em: 22 Jul. 2015.

284. Segatto C. Pai gordo, filho obeso...e neto acima do peso. Revista Época edicação 780 maio 2013. Disponível em: http://revistaepoca.globo.com/Saudee-bem-estar/noticia/2013/05/pai-gordo-filho-obeso-e-neto-acima-do-peso.html>. Acesso em: 16 Fev. 2015. 
285. Barros Filho AA. Um quebra-cabeça chamado obesidade. J Pediatr 2004; 80(1):1-3.

Disponível em:<http://repositorio.unicamp.br/jspui/handle/REPOSIP/12635>. Acesso em: 16 Abr. 2013.

286. Jahnke DL, Warschburger PA. Familial transmission of eating behaviors in preschool-aged children. Obesity (Silver Spring) 2008; 16(8):18211825. Disponível em:<http://www.ncbi.nlm.nih.gov/pubmed/18483480>. Acesso em: 16 Fev. 2015.

287. Camargo APPM, Barros Filho AA, Antonio MARGM, Giglio JS. A não percepção da obesidade pode ser um obstáculo no papel das mães de cuidar de seus filhos. Ciênc. saúde coletiva[online]. 2013, vol.18, n.2. Disponível em:<http://www.scielosp.org/pdf/csc/v18n2/04.pdf>. Acesso em: 14 Abr. 2015.

288. Haddad MCL, Leroux AMR; Santos CF, Loman H, Oliveira SG. Qualidade de vida após gastroplastia. Revista Ciência, Cuidado e Saúde. Maringá, v. 2, n. 1 , p. 37-43, jan./jun. $2003 . \quad$ Disponível em:<http://eduem.uem.br/ojs/index.php/CiencCuidSaude/article/viewFile/5566/3 538>. Acesso em: 18 Mai. 2015.

289. Pinheiro N. Obesidade. Rev. Medicina Social de Grupo, São Paulo, №.177, p.5-8, abril/maio/junho. 2002.

290. Neves AS. Mendonça ALO. Alterações na identidade social do obeso: do estigma ao fat pride. Revista Demetra: alimentação, nutrição \& saúde 2014; $9(3) ; \quad 619-631$ Disponível [online] em:<http://www.epublicacoes.uerj.br/index.php/demetra/article/viewFile/9461/10922>. Acesso em: 22 Abr. 2015.

291. Le Breton D. Adeus ao corpo: antropologia e sociedade. Campinas: Papirus, 2007.

292. Ryan W. Blame the victim. New York: Vintage Books, 1971.

293. Bagdade PS, Grothe KB. Psychosocial evaluation, preparation, and followup for bariatric surgery patients. Diabetes Spectr 2012;25(4):211-216. Disponível [online] em:<http://spectrum.diabetesjournals.org/content/25/4/211>. Acesso em: 18 Ago. 2014.

294. Oliveira VM, Linardi RC, Azevedo AP. Cirurgia bariátrica: aspectos psicológicos e psiquiátricos. Rev Psiquiatr Clín 2004;31(4):199-201. Disponível [online] em:< http://www.scielo.br/scielo.php?script=sci_arttext\&pid=S010160832004000400014>. Acesso em: 22 Out. 2014.

295. Palazuelos-Genis T, Mosti M, Sánchez-Leenheer S, Hernández R, Garduño O, Herrera MF. Weight loss and body composition during the first postoperative year of a laparoscopic roux-en-y gastric bypass. Obes Surg. 2008;18(1):1-4. 
em:<http://www.ncbi.nlm.nih.gov/pubmed/18080722>. Acesso em: 25 Out. 2012.

296. Rizzello M, Abbatini F, Casella G, Alessandri G, Fantini A, Leonetti F, et al. Early postoperative insulin-resistance changes after sleeve gastrectomy. Obes Surg. 2010;20(1):50-5. Disponível [online] em:<http://www.ncbi.nlm.nih.gov/pubmed/19916040>. Acesso em: 12 Jun. 2015.

297. Menenakos E, Stamou KM, Albanopoulos K, Papailiou J, Theodorou D, Leandros E. Laproscopic sleeve gastrectomy performed with intent to treat morbid obesity: a prospective single-center study of 261 patients with a median follow-up of 1 year. Obes surg. 2010;20(3):276-82.

298. Martins JS. Exclusão e a Nova Desigualdade Social. São Paulo. Paulus, 1997.

299. Agra G, Henriques MERM. Vivência de mulheres que se submeteram à gastroplastia. RevEletr Enf. 2009;11(4):982-92. Disponível [online] em:< https://www.researchgate.net/publication/41025043_Vivencia_de_mulheres_qu e_se_submeteram_a_gastroplastia>. Acesso em: 14 mar. 2011.

300. Damasceno VO, Vianna VRA, Vianna JM, Lacio M, Lima JRP, Novaes JS. Imagem corporal e corpo ideal. R brasCi e Mov. 2006;14(1):87-96.

301. Nascimento WF. Por uma vida descolonizada: diálogos entre a bioética de intervenção e os estudos sobre colonialidade. Disponível [online] em: <http://repositorio.unb.br/bitstream/10482/7898/3/2010_WandersonFlorDoNasci mento.pdf>. Acesso em: 10 Mai. 2015. 
ANEXO I 


\section{RESOLUÇÃO CFM No 1.942/2010 $^{\circ}$}

(Publicada no D.O.U. de 12 de fevereiro de 2010, Seção I, p. 72)

Altera a Resolução CFM n ${ }^{\text {1.76 }}$, de 13 de maio de 2005, publicada no Diário Oficial da União em 11 de julho de 2005 ,

Seção I, página 114, que estabelece normas seguras para o tratamento cirúrgico da obesidade mórbida, definindo indicações, procedimentos e equipe.

O CONSELHO FEDERAL DE MEDICINA, no uso das atribuições conferidas pela Lei $n^{\circ} 3.268$, de 30 de setembro de 1957, regulamentada pelo Decreto $n^{\circ} 44.045$, de 19 de julho de 1958, respectiva e posteriormente alterados pela Lei nำ11.000, de 15 de dezembro de 2004, e Decreto nํ⒍821, de 14 de abril de 2009, e

CONSIDERANDO que o alvo de toda a atenção do médico é a saúde do ser humano, em benefício da qual deverá agir com o máximo de zelo e o melhor de sua capacidade profissional;

CONSIDERANDO que o médico deve aprimorar continuamente seus conhecimentos e usar o melhor do progresso científico em benefício do paciente;

CONSIDERANDO que é vedado ao médico efetuar qualquer procedimento médico sem o esclarecimento e o consentimento prévios do paciente ou de seu responsável legal, salvo em iminente perigo de vida;

CONSIDERANDO que o Conselho Federal de Medicina é órgão supervisor da ética profissional em toda a República e, ao mesmo tempo, julgador e disciplinador da classe médica, cabendo-lhe zelar e trabalhar por todos os meios ao seu alcance pelo perfeito desempenho ético da medicina e pelo prestígio e bom conceito da profissão e dos que a exerçam legalmente (art. $2^{\circ}$ da Lei $n^{\circ} 3.268 / 57$ );

CONSIDERANDO a necessidade de normatização do tratamento cirúrgico da obesidade mórbida;

CONSIDERANDO a necessidade de atualização da Resolução CFM nํ 1.766/05;

CONSIDERANDO o Parecer CFM nำ 18/09, aprovado na sessão plenária de 12 de novembro de 2009;

CONSIDERANDO o decidido na sessão plenária de 4 de fevereiro de 2010,

RESOLVE:

Art. $1^{\circ}$ Alterar o artigo $2^{\circ}$ da Resolução CFM № 1.766/05, que passa a ter a seguinte redação:

"Art. $2^{\circ}$ Novos procedimentos, quando necessários, serão analisados pela Câmara Técnica sobre Cirurgia Bariátrica para Tratamento de Obesidade Mórbida”.

Art. $2^{\circ}$ Alterar o anexo da Resolução CFM nำ 1.766/05.

Art. $3^{\circ}$ Esta resolução entra em vigor na data de sua publicação.

Brasília-DF, 5 de fevereiro de 2010

ROBERTO LUIZ D'AVILA

Presidente
HENRIQUE BATISTA E SILVA

Secretário-geral 


\section{ANEXO DA RESOLUÇÃO 1.942/2010}

\section{INDICAÇÕES GERAIS}

Pacientes com Índice de Massa Corpórea (IMC) acima de $40 \mathrm{~kg} / \mathrm{m}^{2}$. Pacientes com IMC maior que 35 $\mathrm{kg} / \mathrm{m}^{2}$ e afetado por comorbidezes (doenças agravadas pela obesidade e que melhoram quando a mesma é tratada de forma eficaz) que ameacem a vida, tais como diabetes tipo 2, apneia do sono, hipertensão arterial, dislipidemia, doença coronariana, osteo-artrites e outras. Idade: maiores de 18 anos. Idosos e jovens entre 16 e 18 anos podem ser operados, mas exigem precauções especiais e o risco/benefício deve ser muito bem analisado. Obesidade estabelecida, conforme os critérios acima, com tratamento clínico prévio insatisfatório de, pelo menos, dois anos. Não uso de drogas ilícitas ou alcoolismo. Ausência de quadros psicóticos ou demenciais graves ou moderados. Compreensão, por parte do paciente e familiares, dos riscos e mudanças de hábitos inerentes a uma cirurgia de grande porte sobre o tubo digestivo e da necessidade de acompanhamento pós-operatório com a equipe multidisciplinar, a longo prazo.

2. RISCO ANESTÉSICO-CIRÚRGICO: Deve ser compatível com o procedimento cirúrgico proposto.

3. EQUIPE: Precisa ser capacitada para cuidar do paciente nos períodos pré e trans-operatório, e fazer o seguimento do mesmo.

COMPOSIÇÃO: cirurgião com formação específica, endocrinologista, nutrólogo ou nutricionista, psiquiatra ou psicólogo. A equipe de atendimento hospitalar deve estar familiarizada com as características da população atendida e os efeitos dos procedimentos cirúrgicos, sendo composta por anestesiologista, fisioterapeuta e equipe de enfermagem.

4. HOSPITAL: Precisa apresentar condições adequadas para atender pacientes portadores de obesidade mórbida, bem como possuir UTI e aparelho anestésico regulável para ciclagem com grandes volumes e baixa pressão.

\section{PROCEDIMENTOS ACEITOS}

\section{A) RESTRITIVOS}

1- BALÃO INTRAGÁSTRICO - colocação de um balão intragástrico por via endoscópica, com cerca de $500 \mathrm{ml}$ de líquido, objetivando diminuir a capacidade gástrica do paciente, provocando a saciedade e diminuindo o volume residual disponível para os alimentos. Método provisório: o balão deve ser retirado no prazo recomendado pelo fabricante. 
INDICAÇÃO: adjuvante do tratamento de perda de peso, principalmente no preparo pré-operatório de pacientes com superobesidade (IMC acima de $50 \mathrm{~kg} / \mathrm{m}^{2}$ ), com associação de patologias agravadas e/ou desencadeadas pela obesidade mórbida.

CONTRA-INDICAÇÕES: esofagite de refluxo; hérnia hiatal; estenose ou divertículo de esôfago; lesões potencialmente hemorrágicas, como varizes e angiodisplasias; cirurgia gástrica ou intestinal de ressecção; doença inflamatória intestinal; uso de anti-inflamatórios, anticoagulantes, álcool ou drogas e transtornos psíquicos.

COMPLICAÇÕES: aderências ao estômago; passagem para o duodeno; intolerância ao balão, com vômitos incoercíveis; úlceras e erosões gástricas; esvaziamento espontâneo do balão; obstrução intestinal por migração do balão; perfuração gástrica; infecção fúngica em torno do balão.

\section{2- GASTROPLASTIA VERTICAL BANDADA OU CIRURGIA DE MASON - nesse procedimento é} criado um pequeno reservatório gástrico na região da cárdia, com capacidade em torno de $20 \mathrm{ml}$, cuja saída é regulada por um anel de polipropileno. Essa intervenção provoca menor perda de peso que outros procedimentos cirúrgicos, e consequente melhoria das comorbidezes de maneira menos intensa.

Em virtude da limitação da eficácia terapêutica dessa técnica, sua utilização deve ser reservada para casos excepcionais.

3- BANDA GÁSTRICA AJUSTÁVEL - é uma prótese de silicone que, colocada em torno do estômago proximal, o faz ter a forma de uma ampulheta ou câmara acima da banda. O diâmetro interno da banda pode ser regulado no pós-operatório por injeção de líquido no reservatório situado no subcutâneo, de fácil acesso.

VANTAGENS: método reversível, pouco agressivo, permite ajustes individualizados no diâmetro da prótese. Sua retirada possibilita realizar outros procedimentos bariátricos, mínimas repercussões nutricionais. Não há secção e sutura do estômago. Baixa morbimortalidade operatória e retorno precoce às atividades habituais.

DESVANTAGENS: perda de peso que pode ser insuficiente a longo prazo; exige estrita cooperação do paciente em seguir as orientações dietoterápicas; riscos inerentes ao uso permanente de corpo estranho; inadequada para alguns pacientes, comedores de doce, portadores de esofagite de refluxo e hérnia hiatal volumosa; possibilidade de ocorrência de complicações a longo prazo, como migração intragástrica da banda, deslizamento da banda e complicações com o reservatório.

4- GASTRECTOMIA VERTICAL - a gastrectomia vertical (gastrectomia em manga, gastrectomia longitudinal, gastrectomia sleeve) é um dos novos procedimentos bariátricos do armamentário cirúrgico que tem recebido aceitação global, com bons resultados em múltiplos centros em vários países. Funciona com uma restrição gástrica, com remoção de $70 \%$ a $80 \%$ do estômago proximal ao antro, 
assim como um componente hormonal associado (redução da grelina). Como os demais procedimentos cirúrgicos bariátricos, deve ser realizada por equipes bem treinadas, com habilitação específica e suporte multidisciplinar adequado.

VANTAGENS: não exclui o duodeno do trânsito alimentar, portanto não interfere com o sítio de absorção de ferro, cálcio, zinco e vitaminas do complexo B. Pode ser transformada, em caso de insucesso, num procedimento com algum componente disabsortivo como o bypass gástrico em $Y$ de Roux e a derivação bilio-pancreática com duodenal switch. Permite acesso às vias biliar e pancreática por métodos endoscópicos habituais.

DESVANTAGENS: método irreversível. Apesar de menor complexidade técnica, pode produzir complicações de alta gravidade e difícil tratamento, como a fístula junto a ângulo de Hiss (esôfagogástrico). Ainda não existem dados consistentes quanto à sua eficácia a longo prazo na perda e manutenção do peso.

\section{B) CIRURGIAS DISABSORTIVAS}

Essas cirurgias, derivação jejuno-ileal e suas variantes de atuação puramente no intestino delgado, estão proscritas em vista da alta incidência de complicações metabólicas e nutricionais a longo prazo. $O$ princípio fundamental das mesmas é a perda, pelas fezes, das calorias ingeridas. As complicações ocorrem pela grande quantidade de intestino desfuncionalizado, que leva a um supercrescimento bacteriano no extenso segmento intestinal excluído, provocando alta incidência de complicações digestivas tais como diarreia, cirrose, pneumatose intestinal e artrites. Pelo exposto, não mais devem ser realizadas.

\section{C) CIRURGIAS MISTAS}

As cirurgias mistas para tratamento de obesidade mórbida associam restrição e disabsorção de nutrientes em maior ou menor grau pelo intestino, dependendo da técnica empregada e da extensão do intestino delgado excluído do trânsito alimentar, levando a perdas ponderais significativas. Além disso, essas cirurgias têm efeitos independentes da perda de peso ao modificar a produção de hormônios gastrintestinais, cujos efeitos podem afetar a saciedade e a produção de insulina.

1- CIRURGIAS MISTAS COM MAIOR COMPONENTE RESTRITIVO - esse grupo de cirurgias compreende as diversas modalidades de derivação gástrica com reconstituição do trânsito intestinal em Y de Roux.

CIRURGIA REGULAMENTADA: cirurgia de gastroplastia com reconstituição em Y de Roux. 
Essa cirurgia, além da restrição mecânica representada pela redução gástrica, restringe a ingestão alimentar e modifica a produção de hormônios que modulam a fome e a saciedade.

Acreditava-se que a colocação de um anel estreitando a passagem pelo reservatório antes da saída da bolsa para a alça jejunal retardaria o esvaziamento para sólidos, aumentando, ainda mais, a eficácia dos procedimentos. Atualmente, a literatura aponta para resultados benéficos semelhantes com ou sem anel. Complicações nutricionais podem ser mais frequentes com a colocação do anel.

VANTAGENS: perda de peso adequada e duradoura, com baixo índice de insucesso. Tratam também a doença do refluxo. Apresentam taxas aceitáveis de complicações a longo prazo. São potencialmente reversíveis, embora com dificuldade técnica. Apresentam bons resultados em termos de melhoria da qualidade de vida e doenças associadas. Essa operação também apresenta efeitos metabólicos independentes da perda de peso. Ocorrem modificações funcionais e hormonais do tubo digestivo, com efeitos benéficos adicionais sobre o controle ou reversão das comorbidezes metabólicas, em especial sobre o diabetes tipo 2.

DESVANTAGENS: tecnicamente complexas; acesso limitado ao estômago excluído e ao duodeno para métodos radiológicos e endoscópicos; passíveis de complicações como deiscência de suturas; maiores chances de deficiências protéicas e anemia do que as cirurgias restritivas.

2- CIRURGIAS MISTAS COM MAIOR COMPONENTE DISABSORTIVO - são procedimentos que envolvem menor restrição da capacidade gástrica, o que permite maior ingestão alimentar, com predomínio do componente disabsortivo.

CIRURGIAS REGULAMENTADAS: a) cirurgia de derivação bílio-pancreática com gastrectomia horizontal (cirurgia de Scopinaro); b) cirurgia de derivação bílio-pancreátrica com gastrectomia vertical e preservação do piloro (cirurgia de duodenal switch). Essas técnicas também apresentam efeitos independentes da perda de peso. Ocorrem modificações funcionais e hormonais do tubo digestivo, com efeitos benéficos adicionais sobre o controle ou reversão das comorbidezes metabólicas, em especial sobre o diabetes tipo 2 e a dislipidemia.

VANTAGENS: há menor restrição da ingestão alimentar; são muito eficazes em relação à perda de peso e manutenção a longo prazo. O reservatório gástrico é completamente acessível aos métodos de investigação radiológica e endoscópica.

DESVANTAGENS: mais sujeitos às complicações nutricionais e metabólicas de controle mais complexo, tais como deficiência de vitaminas lipossolúveis, deficiência de vitamina B12, cálcio, e ferro; desmineralização óssea; úlcera de boca anastomótica; aumento do número de evacuações diárias, com fezes e flatos muito fétidos. 
ANEXOII 


\section{CONSELHO FEDERAL DE MEDICINA}

\section{RESOLUÇÃO № 2.131, DE 12 DE NOVEMBRO DE 2015}

Altera o anexo da Resolução CFM no 1.942/10, publicada no DOU de 12 de fevereiro de 2010, Seção 1, pág. 266.

O CONSELHO FEDERAL DE MEDICINA, no uso das atribuições conferidas pela Lei ํo 3.268 , de 30 de setembro de 1957, regulamentada pelo Decreto o 44.045, de 19 de julho de 1958, e pela Lei no 11.000 , de 15

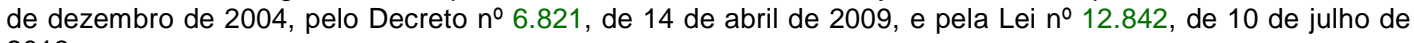
2013;

CONSIDERANDO que a obesidade é doença cada vez mais comum, cuja prevalência já atinge proporções epidêmicas.

Considerando que uma grande preocupação médica é o risco elevado de doenças associadas ao sobrepeso e à obesidade, tais como diabetes, doenças cardiovasculares (DCV) e alguns cânceres;

CONSIDERANDO que é importante o conhecimento das comorbidezes mais frequentes para permitir 0 diagnóstico precoce, a prevenção e o tratamento dessas condições, e para identificar os pacientes que possam se beneficiar com a perda de peso;

Considerando que isso permitirá a identificação precoce e a avaliação de risco, de forma que intervenções adequadas possam ser realizadas para reduzir a mortalidade associada;

CONSIDERANDO que o avanço do conhecimento científico já permite identificar a cirurgia bariátrica como forma eficaz de tratamento da obesidade mórbida a curto e longo prazos e que o conhecimento dos mecanismos de funcionamento das operações atualmente é mais claro;

CONSIDERANDO que 0 artigo $7^{\circ}$ da Lei $\mathrm{n}^{\circ}$ 12.842/2013 estabelece que compreende-se entre as competências do Conselho Federal de Medicina editar normas para definir o caráter experimental de procedimentos de medicina, autorizando e vedando a sua prática pelos médicos;

CONSIDERANDO a necessidade de atualização do Anexo da Resolução CFM no 1.942/2010;

CONSIDERANDO, finalmente, o decidido na Sessão Plenária do Conselho Federal de Medicina realizada em 12 de novembro de 2015, resolve:

Art. 1ํA Alterar o Anexo da Resolução CFM ํㅜ 1.942/2010. Art. 2º Revogam-se as disposições em contrário.

Art. $3^{\circ}$ Esta Resolução entra em vigor na data da sua publicação.

\section{CARLOS VITAL TAVARES CORRÊA LIMA \\ Presidente do Conselho}

HENRIQUE BATISTA E SILVA

Secretário-Geral

ANEXO

\section{INDICAÇÕES GERAIS}

Pacientes com índice de massa corpórea (IMC) acima de $35 \mathrm{~kg} / \mathrm{m} 2$.

Pacientes com IMC maior que $35 \mathrm{~kg} / \mathrm{m} 2$ e portadores de comorbidezes (doenças agravadas pela obesidade e que melhoram quando a mesma é tratada de forma eficaz) que até ameacem a vida como: diabetes, apneia do sono, hipertensão arterial, dislipidemia, doenças cardiovasculares incluindo doença arterial coronariana, infarto do miocárdio (IM) angina, insuficiência cardíaca congestiva (ICC), acidente vascular cerebral, hipertensão e fibrilação atrial, cardiomiopatia dilatada, cor pulmonale e síndrome de hipoventilação, asma grave não controlada, osteoartroses, hérnias discais, refluxo gastroesofageno, com indicação cirúrgica, colecistopatia calculosa, pancreatites agudas de repetição, esteatose hepática, incontinência urnária de esforço da mulher, infertilidade masculina e feminina, disfunção erétil, síndrome dos ovários policísticos, veias varicosas e doença hemorroidária, hipertensão intracraniana idiopática (pseudotumor cerebri), estigmatização social e depressão.

Idade: maiores de 18 anos.

Obesidade estabelecida conforme os critérios acima, com tratamento clínico prévio insatisfatório de, pelo menos, dois anos.

\section{PRECAUÇÕES PARA INDICAÇÃO DA CIRURGIA}

Não uso de drogas ilícitas ou alcoolismo.

Ausência de quadros psicóticos ou demenciais graves ou moderados.

Compreensão, por parte do paciente e familiares, dos riscos e mudanças de hábitos inerentes a uma cirurgia de grande porte sobre o tubo digestivo e da necessidade de acompanhamento pós-operatório com a equipe multidisciplinar, a longo prazo.

Adolescentes com 16 anos completos e menores de 18 anos poderão ser operados, respeitadas as condições acima, além das exigências legais, de ter a concordância dos pais ou responsáveis legais, a presença de pediatra na equipe multiprofissional, a consolidação das cartilagens das epífises de crescimento dos punhos e outras precauções especiais, com o risco-benefício devendo ser muito bem analisado.

Não existem evidências na literatura que respaldem a realização de cirurgia bariátrica em menores de 16 anos, sendo a mesma considerada experimental nesta faixa etária, só podendo ser realizada sob as normas do sistema CEP/CONEP. 
Pacientes acima de 65 anos poderão realizar a cirurgia respeitadas as condições gerais acima elencadas, além de avaliação individual por equipe multiprofissional, avaliação criteriosa do riscobenefício, risco cirúrgico, presença de comorbidezes, expectativa de vida e benefícios do emagrecimento.

\section{RISCO ANESTÉSICO-CIRÚRGICO}

Deve ser compatível com o procedimento cirúrgico proposto.

\section{EQUIPE}

Precisa ser capacitada para cuidar do paciente nos períodos pré e transoperatório e fazer o seguimento do mesmo.

COMPOSIÇÃO: cirurgião com formação específica, endocrinologista, psiquiatra, nutrólogo, nutricionista e psicólogo. Se necessário, para melhor tratamento dos pacientes, outros especialistas, como cardiologistas e pneumologistas, podem ser acionados. A equipe de atendimento hospitalar deve estar familiarizada com as características da população atendida e os efeitos dos procedimentos cirúrgicos, sendo composta por anestesiologista, fisioterapeuta e equipe de enfermagem.

\section{HOSPITAL}

Precisa apresentar condições adequadas para atender a pacientes portadores de obesidade mórbida, bem como possuir UTI e aparelho anestésico regulável para ciclagem com grandes volumes e baixa pressão.

\section{PROCEDIMENTOS RECONHECIDOS}

\section{A) ENDOSCÓPICOS}

BALÃO INTRAGÁSTRICO: colocação de um balão intragástrico por via endoscópica, com cerca de $500 \mathrm{ml}$ de líquido, objetivando diminuir a capacidade gástrica do paciente, provocando a saciedade e diminuindo o volume residual disponível para os alimentos. Método provisório: o balão deve ser retirado no prazo recomendado pelo fabricante.

INDICAÇÃO: adjuvante do tratamento de perda de peso, principalmente no preparo pré-operatório de pacientes com supero-2 obesidade (IMC acima de $50 \mathrm{~kg} / \mathrm{m}$ ), com associação de patologias agravadas e/ou desencadeadas pela obesidade mórbida.

CONTRA-INDICAÇÕES: esofagite de refluxo; hérnia hiatal; estenose ou divertículo de esôfago; lesões potencialmente hemorrágicas, como varizes e angiodisplasias; cirurgia gástrica ou intestinal de ressecção; doença inflamatória intestinal; uso de antiinflamatórios, anticoagulantes, álcool ou drogas e transtornos psíquicos.

COMPLICAÇÕES: aderências ao estômago; passagem para o duodeno; intolerância ao balão, com vômitos incoercíveis; úlceras e erosões gástricas; esvaziamento espontâneo do balão; obstrução intestinal por migração do balão; perfuração gástrica; infecção fúngica em torno do balão.

\section{B) CIRÚRGICOS NÃO DERIVATIVOS}

BANDA GÁSTRICA AJUSTÁVEL: é uma prótese de silicone que, colocada em torno do estômago proximal, o faz ter a forma de uma ampulheta. O diâmetro interno da banda pode ser regulado no pós-operatório por injeção de líquido no reservatório situado no subcutâneo.

VANTAGENS: método reversível, pouco agressivo, permite ajustes individualizados no diâmetro da prótese, mínimas repercussões nutricionais. Sua retirada possibilita realizar outros procedimentos bariátricos. Não há secção e sutura do estômago. Baixa morbimortalidade operatória e retorno precoce às atividades habituais.

DESVANTAGENS: perda de peso que pode ser insuficiente a longo prazo; exige estrita cooperação do paciente em seguir as orientações dietoterápicas; riscos inerentes ao uso permanente de corpo estranho; inadequada para alguns pacientes, comedores de doce, portadores de esofagite de refluxo e hérnia hiatal volumosa; possibilidade de ocorrência de complicações a longo prazo, como migração intragástrica da ban da, deslizamento da banda e complicações com o reservatório. Os resultados pobres e o alto índice de reoperação deixam a indicação desta técnica como exceção.

GASTRECTOMIA VERTICAL: a gastrectomia vertical (gastrectomia em manga, gastrectomia longitudinal) é um procedimento bariátrico do armamentário cirúrgico que possui aceitação global, com bons resultados em múltiplos centros em vários países. Funcionam com restrição gástrica, com remoção de $70 \%$ a $80 \%$ do estômago proximal ao antro, assim como outros mecanismos neuroendócrinos e fisiológicos associados. Como os demais procedimentos cirúrgicos bariátricos, deve ser realizada por equipes bem treinadas, com habilitação específica e suporte multidisciplinar adequado.

VANTAGENS: não exclui o duodeno do trânsito alimentar, portanto não interfere no sítio de absorção de ferro, cálcio, zinco e vitaminas do complexo B; pode ser transformada, em caso de insucesso, em qualquer outra técnica bariátrica regulamentada; permite o acesso às vias biliar e pancreática por métodos endoscópicos habituais.

DESVANTAGENS: método irreversível, que pode produzir complicações de alta gravidade e difícil tratamento, como a fístula junto a ângulo de Hiss (esôfago-gástrico), porém em baixa incidência; existem dados que demonstram perda de peso aceitável em longo prazo, melhor que a banda gástrica ajustável, porém menor que outros procedimentos derivativos.

\section{C) CIRURGIAS DERIVATIVAS}

Cirurgias derivativas são aquelas que desviam o trajeto do alimento pelo tubo digestório e por diversos mecanismos de ação que incluem má absorção de gorduras e levam a perda ponderal significativa a longo prazo.

Essas cirurgias têm efeitos independentes da perda de peso ao modificar a produção de hormônios gastrintestinais, cujos efeitos podem afetar a saciedade e a secreção de insulina pelo pâncreas, entre outros mecanismos, como alteração de secreção de ácidos biliares secundários e até modificação da flora bacteriana intestinal.

Esse grupo de cirurgias compreende as diversas modalidades de derivação gástrica com reconstituição do trânsito intestinal em Y de Roux e as derivações bílio-pancreáticas (à Scopinaro ou "switch" duodenal).

Cirurgia de derivação gástrica com reconstituição em $Y$ de Roux sem ressecção gastrointestinal (bypass gástrico) 
Essa cirurgia tem inicial e transitório componente restritivo alimentar e modifica a produção de hormônios que modulam a fome e a saciedade.

VANTAGENS: perda de peso adequada e duradoura, com baixo índice de insucesso; trata também a doença do refluxo gastroesofageano; apresenta taxas aceitáveis de complicações em longo prazo; é potencialmente reversível, embora com dificuldade técnica; apresenta bons resultados em termos de melhoria da qualidade de vida e doenças associadas.

Essa operação também apresenta efeitos metabólicos independentes da perda de peso. Ocorrem modificações funcionais e hormonais do tubo digestório, com efeitos benéficos adicionais sobre o controle ou reversão das comorbidezes metabólicas, em especial sobre o diabetes tipo 2.

DESVANTAGENS: tecnicamente mais complexa; acesso limitado ao estômago excluído e ao duodeno para métodos radiológicos e endoscópicos; passível de complicações, como deiscência de suturas; maiores chances de deficiências proteicas e anemia do que as cirurgias restritivas.

\section{DERIVAÇÕES BILEOPANCREÁTICAS}

A) cirurgia de derivação bílio-pancreática com gastrectomia horizontal (cirurgia de Scopinaro); B) cirurgia de derivação bíliopancreática com gastrectomia vertical e preservação do piloro (cirurgia de duodenal switch).

Essas técnicas também apresentam efeitos independentes da perda de peso. Ocorrem modificações funcionais e hormonais do tubo digestório, com efeitos benéficos adicionais sobre o controle ou reversão das comorbidezes metabólicas, em especial sobre o diabetes tipo 2 e a dislipidemia.

VANTAGENS: há menor restrição da ingestão alimentar; são muito eficazes em relação à perda de peso e manutenção em longo prazo; o reservatório gástrico é completamente acessível aos métodos de investigação radiológica e endoscópica.

DESVANTAGENS: mais sujeitas às complicações nutricionais e metabólicas de controle mais complexo, tais como deficiência de vitaminas lipossolúveis, deficiência de vitamina B12, cálcio e ferro; desmineralização óssea; úlcera de boca anastomótica; aumento do número de evacuações diárias, com fezes e flatos muito fétidos.

\section{D) CIRURGIAS EXPERIMENTAIS}

São consideradas experimentais ou em investigação aquelas técnicas realizadas sob protocolo de pesquisa, sob a supervisão de Comissões de Ética em Pesquisa (CEP) e/ou Comissão Nacional de Ética em Pesquisa (Conep). Essas operações devem seguir as regulamentações de pesquisas em seres humanos e obrigatoriamente estar registradas na Plataforma Brasil do Conep, e após essa fase deverão ser aprovadas na Câmaras Técnica de Novos Procedimentos e Indicações do CFM, nos termos da Resolução 466/12 do CNS, da Resolução 1.499/98 e da Resolução 1.982/2012 do Conselho Federal de Medicina.

Quaisquer propostas cirúrgicas que não sejam banda gástrica ajustável, gastrectomia vertical, derivação gastrojejunal em $Y$ de Roux, cirurgia de Scopinaro ou de "switch duodenal" não devem ser indicadas, salvo aquelas que sejam operações experimentais que tiverem sua normatização estabelecida no CFM e no Conep e sob protocolos de investigação científica.

\section{E) CIRURGIAS PROSCRITAS}

A derivação jejunoileal exclusiva (término-lateral ou láterolateral ou parcial) está proscrita em vista da alta incidência de complicações metabólicas e nutricionais em longo prazo. As complicações ocorrem pela grande quantidade de intestino desfuncionalizado, que leva a um supercrescimento bacteriano no extenso segmento intestinal excluído, provocando alta incidência de complicações digestivas como diarreia, cirrose, pneumatose intestinal e artrites. Pelo exposto, não mais devem ser realizadas.

\section{EXPOSIÇÃO DE MOTIVOS DA RESOLUÇÃO CFM № 2.131/2015}

Atualmente a obesidade é doença cada vez mais comum e que atinge proporções endêmicas. Por essa razão, uma grande preocupação médica é o elevado risco de doenças associadas ao sobrepeso e à obesidade, tais como diabetes, doenças cardiovasculares (DCV) e alguns tipos de câncer. O conhecimento das comorbidezes mais frequentes nos casos de obesidade facilita o diagnóstico precoce, a prevenção e o respectivo tratamento. Importa saber como identificar os pacientes que podem se beneficiar da perda de peso. Isso permitirá a identificação precoce e a avaliação de risco, de modo que as intervenções possam ser realizadas adequadamente para reduzir a mortalidade associada a obesidade. Diante do avanço científico, é possível identificar a cirurgia bariátrica como uma forma eficaz de tratamento da obesidade mórbida a curto e longo prazos, assim como o conhecimento das operações tornou-se mais claro. Em vista do acima exposto, tornou-se imprescindível que o Conselho Federal de Medicina atualizasse as indicações operatórias contidas no Anexo da Resolução CFM no 1.942/2010, incluindo modificações nas faixas etárias dos candidatos, no tempo de tratamento da enfermidade, na classificação dos procedimentos, na justificativa científica de cada técnica já regulamentada à luz dos conhecimentos atuais e na definição do significado dos procedimentos experimentais e proscritos em cirurgia bariátrica. Os comentários sobre as vantagens e desvantagens são baseados em extensa literatura atual. Brasília, 12 de novembro de 2015. MAURO LUIZ DE BRITTO RIBEIRO Relator

RESOLUÇÃO CFM № 2.131/2015 (Publicada no D.O.U. em 13 jan. 2016, Seção I, p. 66). Disponível em:< http://www.jusbrasil.com.br/diarios/107038809/dou-secao-1-13-01-2016-pg-67>. Acesso em: 15 Jan. 2016). 
ANEXO III 


\section{Protocolo para Cirurgia Bariátrica e Metabólica}

1 - O paciente deverá estar enquadrado dentro do diagnóstico de obesidade mórbida e das indicações de Cirurgia Bariátrica, conforme preconiza a Portaria SAS n 492 de 31 de agosto de 2007, abaixo descritas:

a) Portadores de obesidade mórbida com Índice de Massa Corpórea - IMC igual ou superior a 40kg $/ \mathrm{m}^{2}$, sem co-morbidades e que não respondem ao tratamento conservador (dieta, psicoterapia, atividade física, etc), realizado durante pelo menos dois anos e sob orientação direta ou indireta de equipe de hospital credenciado/habilitado como Unidade de Assistência de Alta Complexidade ao paciente portador de obesidade;

b) Portadores de obesidade mórbida com IMC igual ou maior do que $40 \mathrm{~kg} / \mathrm{m}^{2} \mathrm{com}$ co-morbidades que ameaçam a vida;

c) Pacientes com IMC entre 35 e $39,9 \mathrm{~kg} / \mathrm{m}^{2}$ portadores de doenças crônicas desencadeadas ou agravadas pela obesidade.

Porém, os seguintes critérios devem ser observados:

a) Excluir os casos de obesidade decorrente de doença endócrina (por exemplo, Síndrome de Cushing devida a hiperplasia suprarenal);

b) Respeitar os limites da faixa etária de 18 a 65 anos, e o tratamento cirúrgico não deve ser realizado antes de as epífises de crescimento estarem consolidadas nos jovens;

c) Doente ter capacidade intelectual para compreender todos os aspectos do tratamento, bem como dispor de suporte familiar constante;

d) O doente e os parentes que o apóiam deverão assumir o compromisso com o seguimento pósoperatório, que deve ser mantido indefinidamente;

e) O doente não deve apresentar alcoolismo ou dependência química e outras drogas, distúrbio psicótico grave ou história recente de tentativa de suicídio.

Informações necessárias:

a) Idade em anos;

b) Peso em quilogramas;

c) Altura em metros;

d) Índice de Massa Corpórea ou IMC em kg/m²;

e) Duração do tratamento clínico da obesidade em anos;

f) Descrição do tratamento clínico da obesidade (dieta, psicoterapia, atividade física, medicamentos, etc.);

g) O paciente tem capacidade intelectual para compreender todos os aspectos do tratamento? ( ) sim, ( ) não;

h) O paciente dispõe de suporte familiar constante? ( ) sim, ( ) não;

i) O paciente e seus familiares assumem o compromisso com o seguimento pós-operatório por tempo indefinido? ( ) sim, ( ) não;

j) O paciente sofre de alcoolismo? ( ) sim, ( ) não; k) O paciente sofre de dependência química a outras drogas? ( ) sim, ( ) não;

l) O paciente sofre de distúrbio psicótico grave? ( ) sim, ( ) não;

m) O paciente tentou suicídio recentemente? ( ) sim, ( ) não;

n) O paciente sofre de bulimia? ( ) sim, ( ) não;

o) O paciente é portador de doença crônica desencadeada ou agravada pela obesidade? ( ) sim, ( ) não. Em caso afirmativo, assinale abaixo:

- Hipertensão arterial sistêmica: ( ) controlada, ( ) não controlada, ( ) nunca tratou; 
- Doença cardiovascular: ( ) usa medicamento, ( ) não usa medicamento;

- Diabete melito tipo II: ( ) controlado, ( ) não controlado, ( ) nunca tratou;

- Doença pulmonar: ( ) usa medicamento, ( ) não usa medicamento;

- Apnéia do sono: ( ) incapacitante, ( ) não incapacitante;

- Colelitíase: ( ) com sintoma, ( ) assintomático;

- Linfedema: ( ) incapacitante, ( ) não incapacitante

-Artropatia em MMII: ( ) incapacitante; ( ) não incapacitante;

- Hérnia de disco: ( ) com sintomas neurológicos, ( ) sem sintomas neurológicos;

- Manifestações psico-sociais: ( ) com sintomas, ( ) sem sintomas.

Observação 1: 0 enquadramento nas indicações da cirurgia bariátrica está em conformidade com o Anexo I - Diretrizes para a Atenção ao Pacientes com Obesidade Grave, da Portaria 492.

Observação 2: O escore de gravidade do candidato à cirurgia bariátrica está em conformidade com o Formulário I-B da referida portaria, obedece a pontuação abaixo, e prioriza aqueles com 10 ou mais pontos:

\begin{tabular}{|l|l|l|l|}
\hline DOENÇA & $\mathbf{0}$ PONTO & $\mathbf{1}$ PONTO & PONTOS \\
\hline Hipertensão & Nunca tratou & Controlado & Não controlado \\
\hline Cardiovascular & & Sem medicamento & Com medicamento \\
\hline Diabete & Nunca tratou & Controlado & Não controlado \\
\hline Pulmonar & & Sem medicamento & Com medicamento \\
\hline Apneia & & Não incapacitante & Incapacitante \\
\hline Colelitíase & Assintomático & & Sintomático \\
\hline Linfedema & & Não incapacitante & Incapacitante \\
\hline Artropatia & & Não incapacitante & Incapacitante \\
\hline Hérnia discal & & Sem sintomas & Com sintomas \\
\hline Psico-social & Com sintomas & Sem sintomas & \\
\hline
\end{tabular}

2-A CERAC da Unidade Federativa (UF) de origem do paciente deverá enviar laudos dos seguintes exames:

- Hemograma com plaquetas

- Coagulograma (TP e KTTP)

- Uréia e creatinina

- Sódio e potássio

- Glicemia de jejum e hemoglobina glicosilada (HbA1C)

- TGO e TGP

- Fosfatase alcalina

- Gama-glutamil transferase (GGT) 
- Proteínas totais e frações

- Ácido úrico

- T3, T4 e TSH

- Colesterol total, HDL, e triglicerídeos

- Exame de urina

- Exame de fezes

- Teste de gravidez (para mulheres em período fértil)

- Radiografia simples de tórax

- Ecografia (ultrassonografia) abdominal total

- Endoscopia digestiva alta

- Eletrocardiograma (ECG)

- Ecocardiograma bidimensional com fluxo a cores

- Ergometria ou cintilografia miocárdica (quando houver indicação médica)

- Ecodöppler dos membros inferiores (quando houver indicação médica)

- Bronco-provocação com metacolina (quando houver indicação médica)

- Polissonografia (quando houver indicação médica)

Observação 1: A lista de exames está em conformidade com os itens Preparo do Paciente e o Formulário I-C da Portaria 492.

Observação 2: Requisita-se apenas laudos finais conclusivos não havendo necessidade de anexar fotografias ou imagens dos exames.

2-A CERAC da UF de origem do paciente deverá enviar também laudos de todos os especialistas listados abaixo:

a) Cirurgião - relatório da avaliação clínica;

b) Clínico ou Endocrinologista - relatório da avaliação clínica;

c) Psicólogo ou psiquiatra: relatório da avaliação clínica com informação sobre transtornos do humor, do comportamento alimentar, etc.;

d) Cardiologista - relatório da avaliação clínica, pressão arterial (medida com manguito de obeso) e avaliação do risco cirúrgico;

e) Pneumologista - relatório da avaliação clínica e do risco cirúrgico;

f) Nutricionista ou Nutrólogo - relatório atestando tipo de tratamento dietético realizado e resposta obtida em termos de peso perdido;

g) Odontólogo ou Dentista - relatório atestando que o paciente apresenta dentes bem conservados ou que realizou tratamento necessário para recuperar a capacidade de mastigação;

h) Outros especialistas - dependendo do caso, pode ser necessário parecer de outros médicos, por exemplo, Ginecologista e Cirurgião Vascular.

Observação: A lista de especialistas está em conformidade com o Formulário I-C da Portaria 492.

3-O Hospital Consultor emitirá parecer favorável ao encaminhamento do paciente portador de Obesidade Grave nos casos em que todos os requisitos anteriores forem preenchidos e que, também, alcancem 10 ou mais pontos no escore de gravidade. 
Observação: Nos casos em que o pedido de encaminhamento estiver incompleto, ou seja, faltarem laudos de exames ou avaliações de especialistas, será facultado ao Hospital Consultor decidir por umas das três alternativas: (a) negar encaminhamento; (b) solicitar mais informações, e (c) aceitar o encaminhamento.

4 - A Unidade de Assistência de Alta Complexidade ao Paciente Portador de Obesidade Grave (hospital do SUS credenciado para Cirurgia Bariátrica) receberá o encaminhamento e, dependendo da disponibilidade de vaga, poderá iniciar o preparo préoperatório, executar o procedimento cirúrgico e realizar acompanhamento pós-operatório. Os retornos ambulatoriais a este serviço deverão ocorrer nos seguintes momentos:

- 1 mês - consulta com nutricionista, cirurgião e clínico;

- 3 meses - consulta com nutricionista, cirurgião e clínico;

- 6 meses - consulta com nutricionista, cirurgião, clínico e psicólogo;

- 9 meses - consulta com nutricionista, cirurgião e clínico;

- 12 meses - consulta com nutricionista, cirurgião, clínico e psicólogo;

- 18 meses- consulta com nutricionista, cirurgião, clínico e psicólogo;

- 24 meses - consulta com nutricionista, cirurgião, clínico e psicólogo;

- 36 meses e mais - consulta com nutricionista, cirurgião, clínico e psicólogo.

Observação: Os períodos de retorno ambulatorial estão em conformidade com o Formulário I-D da Portaria 492.

5 - Por ocasião das consultas acima estipuladas, a Unidade de Assistência de Alta Complexidade ao Paciente Portador de Obesidade Grave efetuará os seguintes exames:

- Hemograma

- Sódio, potássio

- Proteinograma

- Zinco

- Cálcio, magnésio, fósforo

- Vitamina B12

- Ácido fólico

- Ferritina

- Colesterol total e frações, triglicérides

- Vitamina A

- Vitamina D (25-hidroxi)

Observação: Os exames laboratoriais citados estão em conformidade com o Formulário I-E da Portaria 492.

6 - Em regime ambulatorial, o serviço de saúde pública da UF de origem do paciente deverá oferecer suplementos nutricionais fundamentais para o período pós-operatório, particularmente depois de Gastroplastia com Derivação Intestinal ou de Gastrectomia com ou sem Desvio Duodenal. São recomendados os seguintes nutrientes:

- Vitaminas lipossolúveis (A, D, E, K);

- Complexo B oral, ou Vitamina B12 intramuscular;

- Oligoelementos com Zinco;

- Ferro (quelato) e ácido fólico oral, ou Ferro injetável; 
- Cálcio (quelato ou citrato);

- Proteína (pó ou líquido) oral.

Observação: A indicação de suplementos nutritivos baseia-se no item 7 - Riscos e Complicações da Cirurgia Bariátrica da Portaria 492.

7 - De acordo com critérios específicos, a Unidade de Assistência de Alta Complexidade ao Paciente Portador de Obesidade Grave realizará Cirurgia Plástica Reparadora nos pacientes submetidos previamente a Cirurgia Bariátrica. Para tanto, a CERAC da UF de origem do paciente necessitará responder ao seguinte questionário:

a) Data da realização da cirurgia de obesidade:

b) Dados atuais: peso em $\mathrm{kg}$ e IMC em $\mathrm{kg} / \mathrm{m}^{2}$

c) Quantos quilos o paciente ganhou ou perdeu nos últimos seis meses?

d) Para mamoplastia:

- A ptose mamária produziu desequilíbrio da coluna e incapacidade funcional? ( ) sim, ( ) não; • Ocorreram infecções cutâneas, fúngicas ou bacterianas, de repetição? ( ) sim, ( ) não;

- Na opinião do psiquiatra, o emagrecimento causou alterações psico-patológicas? ( ) sim, ( ) não; e) Para abdominoplastia:

- O abdome em avental produziu desequilíbrio da coluna e incapacidade funcional? ( ) sim, ( ) não;

- Ocorreram infecções cutâneas, fúngicas ou bacterianas, de repetição? ( ) sim, ( ) não;

- Na opinião do psiquiatra, o emagrecimento causou alterações psico-patológicas? ( ) sim, ( ) não; f) Para remoção de excesso de pele no braço e coxa: - O excesso de pele no braço e na coxa produziu limitação da atividade profissional pelo peso e impossibilidade de movimentação? ( ) sim, ( ) não;

- Ocorreram infecções cutâneas, fúngicas ou bacterianas, de repetição? ( ) sim, ( ) não;

- Na opinião do psiquiatra, o emagrecimento causou alterações psico-patológicas? ( ) sim, ( ) não.

Observação 1: As indicações estão em conformidade com o item 9 - Indicação para Cirurgia Plástica Reparadora da Portaria 492, conforme descrição abaixo:

O paciente com aderência ao acompanhamento pós-operatório poderá ser submetido a cirurgia plástica reparadora do abdômen, das mamas e de membros, conforme as diretrizes para a indicação de cirurgia plástica reparadora pós-cirurgia bariátrica, descritas a seguir:

As intervenções reparadoras realizadas após o tratamento da obesidade grave, ou seja, após o emagrecimento máximo obtido, seguirão as recomendações divididas em três classes fundamentais:

Classe I - Há consenso quanto a indicação da realização da cirurgia plástica reparadora;

Classe II - Há controvérsia quanto a indicação de cirurgia plástica reparadora, procedimentos assim classificados não deverão ser autorizados;

Classe III - Há consenso quanto a falta de indicação ou há contra-indicação da cirurgia plástica reparadora.

Classe I: a) mamoplastia: incapacidade funcional pela ptose mamária, com desequilíbrio da coluna; b) abdominoplastia: incapacidade funcional pelo abdomem em avental e desequilíbrio da coluna; c) excesso de pele no braço e coxa: limitação da atividade profissional pelo peso e impossibilidade de movimentação; d) Nas indicações a, b e c: infecções cutâneas de repetição por excesso de pele, com infecções fungicas e bacterianas; e) Nas indicações a, b e c: alterações psico-patológicas devidas à redução de peso (critério psiquátrico).

Classe II - sem especificação

Classe III: a) mamoplastia: incapacidade funcional pela ptose mamária, sem incapacidade funcional, desequilíbrio da coluna, nem piora de auto-estima; b) abdominoplastia: abdomem em avental, sem doenças cutâneas nem desequilíbrio da coluna; c) excesso de pele no braço e coxa: sem limitação da atividade profissional ou impossibilidade de movimentação; d) Nas situações a, b e c: 
ausência de infecções cutâneas de repetição por excesso de pele ou ausência de redução de peso (falta de aderência ao tratamento).

Observação 2: Terão prioridade os casos que tenham mais de 18 meses de pós-operatório da cirurgia bariátrica, que tenham alcançado IMC menor ou igual a $30 \mathrm{~kg} / \mathrm{m}^{2}$, e que tenham estabilizado o peso.

Observação 3: Para cada procedimento de cirurgia reparadora, uma resposta positiva num dos itens do questionário permite autorizar a realização da referida operação.

Observação 4 - De acordo com o parecer do Departamento de Atenção Especializada - DAE/SAS/MS, a Unidade Executante prestará assistência em caso de intercorrências pòs- gastroplastia, considerando que não é permitido a realização deste procedimento em qualquer serviço, resultando da necessidade de concentração do mesmo com responsabilidades pelos procedimentos. Escrito por Carlos Haruo Arasaki (UNIFESP - São Paulo)

Fonte: http://cnrac.datasus.gov.br/cnrac/pdf/ProtocoloClinicoCirurgiaBariatrica.pdf 
APÊNDICE A 


\section{TERMO DE CONSENTIMENTO LIVRE E ESCLARECIDO (TCLE)}

O(a) senhor(a) está sendo convidado(a) a participar da pesquisa intitulada "Uma Análise da Cirurgia Bariátrica a luz da Declaração Universal de Bioética e Direitos Humanos: Não-Discriminação e NãoEstigmatização da Pessoa com Obesidade Mórbida". A pesquisa encontra-se sob a responsabilidade da Doutoranda Sheila Pereira Soares participante do Programa de Pós-Graduação em Bioética da Universidade de Brasília (UnB) sob orientação do Prof. Dr. Natan Monsores de Sá. Tem finalidade acadêmica, objetivando identificar e analisar com base em fundamentação bioética, as implicações éticas decorrentes da cirurgia bariátrica no combate a obesidade, tendo como referência a Declaração Universal sobre Bioética e Direitos Humanos da UNESCO. Os dados serão obtidos por meio de questionários de autopreenchimento, isto é, preenchido pelo próprio participante da pesquisa. O questionário contem 34 questões, sendo fechadas, semi-abertas e perguntas abertas. O tempo estimado para o preenchimento é de 50 minutos. $\mathrm{O}(\mathrm{a})$ senhor(a) tem liberdade e autonomia para decidir participar voluntariamente, podendo recusar-se a participar em qualquer momento sem prejuízo ou penalidade a sua pessoa. Não terá nenhum tipo de despesa, nem receberá pagamento ou qualquer gratificação por sua participação. Poderá recusar-se a responder qualquer questão que lhe traga constrangimento. Em relação aos possíveis riscos de danos, caso o(a) senhor(a) participante se sinta agredido ou ofendido em sua moral, cultura, crença, dignidade, se sinta intimidado, vergonha, humilhado, com medo, discriminado ou exposto terá o direito de reivindicar seus direitos legais conforme legislação vigente Res. CNS 466/2012 e demais que achar necessário. A pesquisadora se responsabilizará pelas eventuais despesas com tratamentos psicológicos ou com medicamentos, desde que comprovadamente tenham sido ocasionado de forma direta ou indireta pela pesquisa ou pesquisadora). O(a) senhor(a) terá a garantia de receber esclarecimentos sobre quaisquer dúvidas acerca dos procedimentos da pesquisa, inclusive sobre o seu andamento e resultados, que serão utilizados para fins educativos e publicação científica, sendo preservada sua identidade. O instrumento utilizado para coleta de dados - questionário - possui perguntas que se referem a aspectos de sua vida íntima em decorrência da obesidade e da cirurgia bariátrica, por este motivo o respeito ao sigilo e a privacidade das informações serão considerados e praticados, assim como guardados sob responsabilidade da pesquisadora, evitando qualquer constrangimento e divulgação além do fim acadêmico. Os benefícios da pesquisa estão voltados para os profissionais da área de saúde e para as pessoas portadoras de obesidade ou que tenham sido submetidas ao procedimento de cirurgia bariátrica, contribuindo para o enriquecimento no campo do saber e melhoria da qualidade das práticas biomédica e respeito à ética da vida. Este TCLE deverá ser impresso em duas vias, sendo uma para o participante da pesquisa e a outra para a pesquisadora. Maiores esclarecimentos poderão ser obtidas por meio do Comitê de Ética e Pesquisa da Faculdade de Ciências da Saúde - UnB. Endereço: Faculdade de Ciências da Saúde. Campus Darcy Ribeiro. Universidade de Brasília. Brasília DF. Brasil. CEP: 70.904-970. Telefone (61) 31071947. E-mail: cepfsunb@gmail.com ou diretamente com a pesquisadora Sheila Pereira Soares pelo telefone (61) 98167597 ou pelo E-mail: guimelodf01@gmail.com. Também pelo Comitê de Ética e Pesquisa da Secretaria de Estado de Saúde do Distrito Federal - FEPECS - Fundação de Ensino e Pesquisa em Ciências da Saúde SMHN Quadra 03, conjunto A, Bloco 1 Edifício Fepecs - tel: (61)3325 4956 . Este projeto foi aprovado sob o número CAAE: 23680113.3.3001.5553. Os questionários utilizados na pesquisa ficarão sob a guarda da pesquisadora por 5 anos.

Tenho ciência do exposto, aceito participar voluntariamente da pesquisa.

Nome ou Rubrica (Opcional):

Assinatura do Pesquisador Responsável:

Brasília, 1 
APÊNDICE B 


\section{QUESTIONÁRIO}

\section{Dados sócio-demográficos}

\begin{tabular}{l|l|l|l}
\hline Idade (anos) & Sexo & Religião & Estado Civil \\
\hline ( ) $18-25$ & ( ) M & ( ) Católico & ( ) Solteiro \\
\hline ( ) $26-30$ & ( ) F & ( ) Protestante & ( ) Casado \\
\hline ( ) $31-35$ & & ( ) Espírita & ( ) Viúvo \\
\hline ( ) $36-40$ & & ( ) Ateu & ( ) União Estável \\
\hline ( ) $41-45$ & & ( ) Não Informado & ( ) Divorciado \\
\hline ( ) $46-50$ & & ( ) Outros & ( ) Separado \\
\hline ( ) $\geq 51$ & & & ( ) Outros \\
\hline
\end{tabular}

\begin{tabular}{l|l|l}
\hline Escolaridade & Categoria Profissional & $\begin{array}{l}\text { Renda familiar } \\
\text { *salário mínimo }\end{array}$ \\
\hline ( ) Analfabeto & ( ) Médico & ( ) $\leq 1$ \\
\hline ( ) Ens. Fund. Completo & ( ) Enfermeiro & ( ) 1 - 3 \\
\hline ( ) Ens. Fund. Incompleto & ( ) Técnico em Enfermagem & ( ) 4- 6 \\
\hline ( ) Ens. Méd. Completo & ( ) Técnico em Laboratório & ( ) 7-9 \\
\hline ( ) Ens. Méd. Incompleto & ( ) Farmacêutico & ( ) $\geq 10$ \\
\hline ( ) Superior Completo & ( ) Nutricionista & ( ) Não Informado \\
\hline ( ) Superior Incompleto & ( ) Técnico Administrativo & \\
\hline ( ) Pós-Graduação & ( ) Outros & \\
\hline & & \\
\hline
\end{tabular}


2. A obesidade sempre esteve presente na sua vida, isto é, desde a infância foi uma pessoa com excesso de peso?

3. Antes da cirurgia, você acha que comia:

( ) Em excesso ( ) Muito ( ) Normal ( ) Pouco

4. Existem obesos na família (parentes de $1^{\circ}$ ou $2^{\circ}$ grau)?
( ) Sim
( ) Não

5. Quais as principais dificuldades na vida cotidiana enfrentados por você (pelos obesos) em consequência da obesidade?

6. Sofreu discriminação e estigmatização em função da obesidade?

( ) Sim

( ) Não

7. Em quais ambientes já sofreu preconceito?

( ) Ambiente familiar

( ) Escola (enquanto aluno)

( ) Escola (enquanto professores)

( ) Trabalho (de colegas)

( ) Trabalho (de pacientes)

( ) Hospital (enquanto pacientes)

( ) Shopping ou lojas

( ) Transporte publico

( ) Outros.

Espaço disponível, caso queira detalhar e compartilhar a experiência sobre preconceito: 
8. Você (enquanto obeso) se considerava uma pessoa:
( ) "Normal”
( ) Doente

9. Doenças relacionadas à obesidade, que você apresentava antes do tratamento cirúrgico:

( ) Síndrome da Apneia Obstrutiva do Sono (parar de respirar enquanto dormia)

( ) Dispnéia (falta de ar) a pequenos esforços

( ) Síndrome do Ronco - Roncador

( ) Diabetes mellitus

( ) Hipertensão arterial (pressão alta)

( ) Doenças cardiovasculares (doenças do coração e circulatório)

( ) Dificuldade de locomoção (dificuldade para andar)

( ) Dislipidemias (colesterol alto)

( ) Esteatose hepática (fígado gorduroso)

( ) Refluxo gastroesofageano

( ) Outras. Quais?

10. Classificação do seu Peso Corporal antes do tratamento cirúrgico:

\begin{tabular}{l|l|l}
\hline Peso Corporal & IMC & Resposta \\
\hline Normal & $20-24,9$ & \\
\hline Sobrepeso & $25-29,9$ & \\
\hline Obesidade Leve Grau I & $30-34,9$ & \\
\hline Obesidade Moderada Grau II & $35-39,9$ & \\
\hline Obesidade Grave Grau III & $>40$ & \\
\hline
\end{tabular}

11. Realizava alguma atividade física antes do procedimento?
( ) Sim
( ) Não

12. Auto avaliação - Histórico Físico e Social antes do tratamento cirúrgico:

\begin{tabular}{l|l|l|l|l|l}
\hline Componente & Ótimo & Bom & Regular & Ruim & Péssimo \\
\hline $\begin{array}{l}\text { Capacidade } \\
\text { Funcional }\end{array}$ & & & & & \\
& & & & & \\
\hline
\end{tabular}




\begin{tabular}{l|l|l|l|l|l}
\hline Aspectos Físicos & & & & & \\
\hline Vida Sexual & & & & & \\
\hline Vitalidade & & & & & \\
\hline Relação social & & & & & \\
\hline Relação emocional & & & & & \\
\hline Saúde Mental & & & & & \\
\hline $\begin{array}{l}\text { Frequentava festas } \\
\text { e shows }\end{array}$ & & & & & \\
\hline Autoestima & & & & & \\
\hline
\end{tabular}

13. Tipos de tratamento da obesidade que você já utilizou antes de submeter-se ao procedimento cirúrgico:

( ) Dietas hipocalóricas e restritivas.

( ) Atividade física.

( ) Medicamentos.

( ) Outros.

Quais?

14. Qual o fator decisivo que motivou a procurar o procedimento de cirurgia bariátrica?

( ) Estética ( ) Saúde

15. Como você acha que as pessoas te percebiam antes do tratamento?

16. Como você se percebia ao se olhar no espelho antes do tratamento?

17. O que você considerava o seu maior problema em relação a obesidade antes do tratamento cirúrgico? 
28. O que você esperava de mudança física e social em sua vida após a cirurgia?

19. Há quanto tempo foi realizada a cirurgia?

( ) 1 ano

( ) 2 anos

( ) 3 anos

( ) 4 anos

( ) mais de 5 anos

20. O procedimento ocorreu por meio de:

( ) Convênio

( ) Particular

( ) SUS - Sistema Único de Saúde

21. Você foi atendido por uma equipe multiprofissional (médicos, psicólogos, nutricionistas, assistente social e outros)?

( ) Sim.

( ) Não.

22. Quanto tempo se preparou para realizar o procedimento, incluindo, indicação, reuniões, consultas e exames pré-operatório?

( ) menos de 1 ano

( ) 1 ano

( ) 2 anos

( ) 3 anos

( ) 4 anos

23. Você foi informado pela equipe multiprofissional sobre os possíveis benefícios e danos à saúde que poderia tecnicamente obter com o procedimento?

( ) Sim.

( ) Não.

24. Você foi informado que o procedimento de cirurgia bariátrica é um ato cirúrgico complexo, de grande porte, com risco de morte e definitivo?

( ) Sim.

( ) Não. 
25. Você foi informado que a manutenção do tratamento é para o resto da vida e inclui cirurgias plásticas corretivas, suplementação nutricional e dieta balanceada?

( ) Sim.

( ) Não.

26. Continua participando das reuniões com uma equipe multiprofissional e consultas após o procedimento?

( ) Sim

( ) Não

27. Você continua a sendo avaliado por um psicólogo após o procedimento?

( ) Sim

( ) Não

28. Como você se percebe ao se olhar no espelho após o tratamento?

29. Ainda sofre dificuldades, discriminação e estigmatização?

( ) Não

( ) Sim.

Espaço disponível, caso queira detalhar e compartilhar a experiência sobre como você acha que as pessoas o/a percebem hoje, após a cirurgia:

30. Já atingir o peso ideal?

( ) Sim

( ) Não

31. Doenças que prevaleceram mesmo após a cirurgia e consequentemente a redução do peso:

( ) Síndrome da Apneia Obstrutiva do Sono (parar de respirar enquanto dormia)

( ) Dispnéia (falta de ar) a pequenos esforços

( ) Síndrome do Ronco - Roncador

( ) Diabetes mellitus

( ) Hipertensão arterial (pressão alta)

( ) Doenças cardiovasculares (doenças do coração e circulatório)

( ) Dificuldade de locomoção (dificuldade para andar)

( ) Dislipidemias (colesterol alto) 
( ) Esteatose hepática (fígado gorduroso)

( ) Refluxo gastroesofageano

( ) Outras. Quais?

33. A cirurgia atendeu os seus objetivos?

( ) Sim

( ) Não.

34. Arrependimento do tratamento cirúrgico?

( ) Sim

( ) Não

Espaço aberto para comentários:

Obrigada pela atenção. 